UNIVERSIDADE DE SÃ PAULO

FACULDADE DE FILOSOFIA, LETRAS E CIENCIAS HUMANAS

DEPARTAMENTO DE GEOGRAFIA

PROGRAMA DE PÓS-GRADUÇÃO EM GEOGRAFIA FÍSICA

GIORGIA LIMNIOS

PATRIMÔNIO PAISAGÍSTICO DAS PEQUENAS CENTRAIS

HIDRELÉTRICAS NO MUNICÍPIO

DE ESPÍRITO SANTO DO PINHAL - SP 
UNIVERSIDADE DE SÃ PAULO

FACULDADE DE FILOSOFIA, LETRAS E CIENCIAS HUMANAS

DEPARTAMENTO DE GEOGRAFIA

PROGRAMA DE PÓS-GRADUÇÃO EM GEOGRAFIA FÍSICA

\section{PATRIMÔNIO PAISAGÍSTICO DAS PEQUENAS CENTRAIS HIDRELÉTRICAS NO MUNICÍPIO DE ESPÍRITO SANTO DO PINHAL - SP}

Tese apresentada ao Departamento de Geografia da Faculdade de Filosofia Letras e Ciências Humanas da Universidade de São Paulo para a obtenção do título de Doutora em Geografia

Área de concentração: Geografia Física - Paisagem e Planejamento Orientadora: Profa. Dra. Sueli Angelo Furlan

SÃO PAULO

2018 
Autorizo a reprodução e divulgação total ou parcial deste trabalho, por qualquer meio convencional ou eletrônico, para fins de estudo e pesquisa, desde que citada a fonte.

Catalogação na Publicação

Serviço de Biblioteca e Documentação

Faculdade de Filosofia, Letras e Ciências Humanas da Universidade de São Paulo

L1mnios, G1org1a

L732p PATRIMONIO PAISAGISTICO DAS PEQUENAS CENTRAIS PINHAL - SP / G1org1a L1mn1os ; or1entadora Profa. Dra. Suel1 Angelo Purlan. - Sao' Paulo, 2018. $164 \mathrm{f}$.

Tege (Doutorado) - Faculdade de P11ogof1a, Letras e C1enclas Humanas da Universidade de sao Paulo. Departamento de Geografia. Área de concentraçao: Geografia Pisica.

1. Pa1sagem. 2. Patrimon1o. 3. Pequena Central H1drelétrica. 4. Bcolog1a đa Pa1sagen. I. Furlan, Profa. Dra. Sueli Angelo, orient. II. Titulo. 
Nome: Limnios, Giorgia

Título: PATRIMÔNIO PAISAGÍSTICO DAS PEQUENAS CENTRAIS HIDRELÉTRICAS NO MUNICÍPIO DE ESPÍRITO SANTO DO PINHAL - SP

Tese apresentada ao Programa de Pós-Graduação em Geografia Física da Faculdade de Filosofia, Letras e Ciencias Humanas da Universidade de São Paulo para obtenção do título de Doutora em Geografia

Aprovada em:

Banca Examinadora

Prof. Dr.

Instituição:

Julgamento:

Assinatura:

Prof. Dr.

Instituição:

Julgamento:

Assinatura:

Prof. Dr.

Instituição:

Julgamento:

Assinatura: 


\section{Resumo}

As pequenas centrais hidrelétricas construídas na primeira metade do século $\mathrm{XX}$, no município de Espírito Santo do Pinhal, são exemplos representativos do período inicial da eletrificação no Estado de São Paulo. Constituem-se de três usinas de pequeno e médio porte instaladas nas margens do Rio Mogi-Guaçu com grande potencial de patrimonialização em virtude dos valores histórico, arquitetônico, paisagístico, tecnológico de uma tipologia industrial pouco reconhecida no âmbito cultural. A pesquisa tem como objetivo propor um delineamento dos limites paisagísticos desse conjunto hidrelétrico, considerando os resultados de parâmetros ecológicos da paisagem como área, número de fragmentos de habitat, índice de fragmentação maior, distância do vizinho mais próximo, forma e área núcleo, analisados a partir do mapeamento de uso e cobertura da terra na escala 1:5.000. Também foram considerados aspectos de visibilidade da paisagem, calculados a partir de pontos determinados na barragem e na casa de máquinas das usinas, para verificar o alcance e direção do panorama a partir desses locais. A área de estudo foi delimitada com auxílio de cartas topográficas na escala 1:10.000 e ortofotos coloridas de 2010 considerando as características físicas e culturais da paisagem. Foram identificadas 17 classes de uso e cobertura da terra, recobrindo área total de 2.075,96 hectares. Apesar da predominância de classes de origem cultural, verificou-se que os remanescentes de vegetação nativa da Floresta Estacional Semidecidual (FES) ocupam 45,47\% do total da paisagem. O limite proposto para proteção da paisagem hidrelétrica abrange as PCHs Salto de Pinhal, Pinhal e Eloy Chaves; significativos remanescentes da Floresta Estacional Semidecidual, diversos cursos d' água e nascentes das subbacias do Rio Mogi-Guaçu, significativos fragmentos de vegetação nativa, totalizando $1.185,37$ ha.

Palavras chave: Patrimônio, Patrimônio Industrial, Paisagem, Pequena Central Hidrelétrica, Cartografia 


\begin{abstract}
Small hydropower plants (SHP) built in the first half of the 20th century, in the municipality of Espírito Santo do Pinhal, are representative examples of the initial electrification process in São Paulo State. This complex of SHPs comprises three small and medium-scale plants installed on the margins of the Mogi-Guaçu River, with a high patrimonialization potential due to the historical, architectural, landscape and technological values of an industrial building type scarcely understood within the cultural scope. The research aims to propose a delineation of the limits of this hydroelectric set landscape, considering landscape's ecological parameters results, such as area, number of fragments of habitat, fragmentation index largest, average nearest neighbor, form index, and core area, analyzed from land use and cover maps at a scale of 1:5,000. Landscape visibility aspects, calculated from certain points located on the dam and the powerhouse, were also considered in order to verify the extent and direction of the panoramic view of these sites. The study area was delimited using 1:10,000 scale topographic maps and colored orthophotos of 2010, considering physical and cultural aspects of the landscape. Seventeen (17) classes of land use and cover have been identified, with a total area of 2,075.96 ha. Despite the predominance of cultural classes, it was found that the remaining native vegetation of the Semideciduous Seasonal Forest (SSF) covers $45.47 \%$ of the current landscape. The limits proposed for the hydropower landscape protection encompasses the Salto de Pinhal, Pinhal and Eloy Chaves Small Hydropower Plants, as well significant remaining native vegetation of the Semideciduous Seasonal Forest, several water bodies and sources of Mogi-Guaçu River sub-basin, and significant native vegetation fragments, totaling 1,185,37 ha.
\end{abstract}

Key words: Heritage, Industrial Heritage, Landscape, Small Hydropower Plants, Cartography 


\section{Lista de Siglas}

\begin{tabular}{|c|c|}
\hline ABAP & Associação Brasileira de Arquitetos Paisagistas \\
\hline APP & Área de Prservação Permanente \\
\hline AUE & Áreas de Urbanização Especial \\
\hline BIR & Bens Imóveis Representativos \\
\hline CAPES & Coordenação de Aperfeiçoamento de Pessoal de Nível \\
\hline CGG & Comissão Geográfica e Geológica \\
\hline CIAGRO & Centro integrado de Informações Agrometeorológicas \\
\hline CONDEPHAAT & $\begin{array}{l}\text { Conselho de Defesa do Patrimônio Histórico, Arqueológico, } \\
\text { Artístico e Turístico do Estado de São Paulo }\end{array}$ \\
\hline CONPRESP & $\begin{array}{l}\text { Conselho Municipal de Preservação do Patrimônio Histórico, } \\
\text { Cultural e Ambiental da Cidade de São Paulo }\end{array}$ \\
\hline CPFL & Companhia Paulista de Força e Luz \\
\hline EMPLASA & Empresa Paulista de Planejamento Metropolitano \\
\hline FES & Floresta Estacional Semidecidual \\
\hline IBGE & Instituto Brasileiro de Geografia e Estatística \\
\hline IFLA & Federação Internacional de Arquitetos Paisagistas \\
\hline IGC & Instituto Geográfico e Cartográfico \\
\hline IPHAN & Instituto do Patrimônio Histórico e Artístico Nacional \\
\hline $\mathrm{Ha}$ & Hectares \\
\hline OEA & Organização dos Estados Americanos \\
\hline $\mathrm{PCH}$ & Pequena Central Hidrelétrica \\
\hline PIB & Produto Interno Bruto \\
\hline SNUC & Sistema Nacional de Unidades de Conservação \\
\hline SPHAN & Serviço do Patrimônio Histórico e Artístico Nacional \\
\hline TICCIH & $\begin{array}{l}\text { The International Committee for the Conservation of the In- } \\
\text { dustrial Heritage }\end{array}$ \\
\hline UNESCO & $\begin{array}{l}\text { United Nations Educational, Scientific and Cultural Organiza- } \\
\text { tion }\end{array}$ \\
\hline ZEPEC & Zona de Preservação Cultural \\
\hline
\end{tabular}




\section{Sumário}

Resumo Abstatc V

Abstratc $\quad$ VI

Lista de Siglas $\quad$ VII

Introdução 9

Materiais e Métodos $\quad 12$

Capítulo 1 - Paisagem 22

$\begin{array}{ll}\text { Ecologia da Paisagem } & 27\end{array}$

Ecologia da Paisagem - uma discussão 33

Medições ecológicas da paisagem $\quad 40$

Efeito de borda e fragmentação $\quad 42$

Capítulo 2- Patrimônio 43

O Tombamento $\quad 53$

$\begin{array}{ll}\text { Chancela da Paisagem } & 57\end{array}$

Proteção da paisagem no Estado de São Paulo

Áreas Envoltórias $\quad 66$

Patrimônio Industrial $\quad 71$

A Pequena Central Hidrelétrica como patrimônio $\quad 75$

$\begin{array}{ll}\text { Usina-Parque } & 81\end{array}$

Capítulo 3 - Café, Ferrovia e Eletricidade

O Café $\quad 83$

$\begin{array}{lr}\text { As Ferrovias } & 88\end{array}$

As primeiras usinas hidrelétricas paulistas 96

$\begin{array}{ll}\text { Resultados } & 116\end{array}$

Considerações Finais $\quad 133$

$\begin{array}{ll}\text { Bibliografia } & 136\end{array}$

$\begin{array}{ll}\text { Anexo } & 148\end{array}$ 


\section{Introdução}

A oportunidade de integrar a equipe do eixo temático "Paisagem e Ambiente" do Projeto "História da Energia Elétrica no Estado de S. Paulo (1890-1960): Patrimônio Industrial, Paisagem e Meio-Ambiente (Eletromemória II)"1 foi decisivo para a escolha do tema desta pesquisa. Esse projeto de força e luz teve como objetivo compreender os processos históricos da implantação da eletrificação no Estado de São Paulo no período de 1890-1960, a partir da construção das pequenas centrais hidrelétricas ( $\mathrm{PCHs}$ ) e registrar um importante acervo documental ainda não patrimonializado. Os atributos da paisagem contribuíram significativamente para a concretização da industrialização paulista, e as marcas desse processo ainda estão presentes no território.

O potencial hidrelétrico da rede hidrográfica paulista foi aproveitado em todas as regiões onde surgiram cidades, indústrias e circuitos de transportes. Há mais de um século, as usinas localizadas nas altas cotas altimétricas da Serra do Mar (ex.: Henri Borden e Itatinga) fornecem energia para as indústrias da região do ABC e Cubatão; e ao Porto de Santos, respectivamente, e ainda operam com alguns equipamentos originais. O potencial hidrelétrico da Serra da Mantiqueira beneficiou diversas cidades localizadas no Vale do Paraíba e em Campos do Jordão, algumas usinas foram construídas nas mais elevadas altitudes, a exemplo da $\mathrm{PCH}$ Fojo e PCH Izabel (barragem localizada a 1850 metros, aproximadamente). Ainda nesse grande compartimento de relevo, nos contrafortes ocidentais, pequenas usinas atendiam as cidades do café e, atualmente, complementam a rede elétrica conforme suas capacidades. $\mathrm{Na}$ bacia do Rio Tietê e seus tributários estão localizadas algumas das mais antigas usinas, hidrelétricas entre elas a pioneira no fornecimento de energia no Estado de São Paulo, a PCH Corumbataí.

As paisagens elétricas refletem a conjunção das qualidades físicas, naturais e culturais que as constituem e permanecem, no tempo e no espaço, como testemunhos históricos, arquitetônicos, técnicos e sociais das transformações dos modos de produzir e viver.

Enfatizando essa junção de aspectos do ambiente, das técnicas e da história CHOAY (2000) apontaqueosbensdevemserprotegidosemumaextensãotripla:tipológica,cronológicaegeográfica.

Algumas tipologias do patrimônio industrial paulista foram alvos de maiores esforços de proteção governamental, enquanto outras não tiveram ainda reconhecimento equivalente. Os mais representativos estão associados às indústrias têxteis e às ferrovias.

O repertório das pequenas centrais hidrelétricas no Estado de São Paulo, construídas entre 1890 e 1960, totaliza, aproximadamente, 130 unidades e a memória da energia paulista está amparada pelo tombamento da PCH Corumbataí (1895), localizada no município de

$1 \quad$ Projeto FAPESP 12/51424 
Rio Claro, como única hidrelétrica protegida pela ação governamental estadual. Ações de proteção das PCHs no âmbito municipal são constatadas nas Usinas Boyes (1938), no município de Piracicaba; e Laranja Doce (1928) no município de Martinópolis. Portanto, verifica-se pequena representatividade desta tipologia industrial no qual recai as ações de proteção.

A implementação das PCHs em terras paulistas teve início há 128 anos com o objetivo principal de iluminação pública e também para atenderà demanda industrial, que expandiu territorialmente a produção de bens de consumo. Antes do início do século XX, havia seis usinas hidrelétricas em operação; e até a década de 1950 esse total era de 119. Buscando um sentido amostral e metodológico para a patrimonialização as usinas escolhidas para a pesquisa foram construídas na primeira metade do século XX, nos anos de 1911 (Salto de Pinhal), 1928 (Pinhal) e 1954 (Eloy Chaves).

As três PCHs estão localizadas nas margens do Rio Mogi-Guaçu, na área ruraldo município de Espírito Santo do Pinhal-SP, no contraforte ocidental da Serra da Mantiqueira, o principal "castelo de águas" do sudeste brasileiro. Olocal apresenta grande potencial paisagístico e histórico a ser considerado nas práticas patrimoniais. As usinas formam um conjunto consolidado na paisagem, estruturadas sobre terrenos ondulados entre coberturas vegetais em diversos estágios de sucessão da floresta estacional semidecidual submontana , culturas de café e eucalipto, pastagens e propriedades rurais. Além disso, a vegetação natural existente na área de estudo faz parte do domínio da Mata Atlântica, considerada patrimônio nacional pela Constituição Federal do Brasil de 1988 .

No primeiro capítulo apresenta-se o pano de fundo da discussão sobre paisagem através de algumas abordagens geográficas sobre que demostram a pluralidade de entendimentos dessa categoria, sobretudo pelas ações transformadoras da cultura, que criam formas e estabelecem funções para demandas específicas, de acordo com as possibilidades paisagísticas. Sob o enfoque ecológico da paisagem ressalta-se o mosaico de elementos interativos naturais e/ou culturais, que apresentam configurações e composições que variam conforme o recorte territorial, a escala espacial e a localização geográfica; passíveis de análises por medidas ecológicas.

No segundo capítulo a temática sobre o patrimônio é apresentada, inicialmente, pelas associações do termo em relação à memória, à ideia de monumento e aos novos significados atribuídos aos fatos de interesse cultural. Alguns dispositivos de proteção refletem conflitos e soluções que envolvem os bens culturais e suas áreas envoltórias. A valorização cultural das paisagens representa um grande avanço nas ações de proteção, possibilitando reconhecer as qualidades materiais e imateriais como componentes integrados ao quadro paisagístico.

O terceiro capítulo trata das principais atividades transformadoras da paisagem no território paulista, principalmente com o advento do café, seguido do impulso industrial com a construção da rede ferroviária, estabelecimentos de indústrias e implantação das hidrelétricas. A PCHs pesquisadas foram apresentadas na forma de ficha descritiva, com indicação das principais carac- 
terísticas arquitetônicas, técnicas, paisagísticas e históricas que as legitimam como bens culturais.

A pesquisa tem como objetivo propor um delineamento dos limites paisagísticos desse conjunto hidrelétrico, considerando os resultados de medidas ecológicas da paisagem analisados por meio do mapeamento de uso e cobertura da terra na escala 1:5.000, e aspectos de visibilidade determinados a partir de pontos específicos de cada $\mathrm{PCH}$.

Como hipótese de pesquisa, as paisagens culturais podem ser estabelecidas e apresentar um bom desenho de conservação adotando-se medidas ecológicas da paisagem como um critério a mais nas práticas patrimoniais. 


\section{Materiais e métodos}

Para o desenvolvimento da pesquisa faz-se necessário estabelecer alguns procedimentos que envolvem atividades de gabinete e atividades de campo, pesquisa bibliográfica, fotográfica, produção cartográfica e checagem de dados.

Alguns temas da Geografia serão abordados na pesquisa para melhor compreensão dos fenômenos que ocorrem na área de estudo, que influenciam na dinâmica da paisagem, como a climatologia, biogeografia, geomorfologia e cartografia, bem como os aspectos históricos e econômicos que revelam o surgimento das PCHs no estado de São Paulo.

Inicialmente foram selecionados textos que envolvem os principais temas de pesquisa referentes à Paisagem, ao Patrimônio e às Pequenas Centrais Hidrelétricas. Também foram verificados os materiais cartográficos (analógicos e digitais) e imagéticos existentes para definição da escala espacial a ser considerada na pesquisa, bem como a legenda para as classes de uso da terra para posterior mapeamento em software de Sistemas de Informações Geográficas (SIG).

Os materiais cartográficos existentes para a área de estudo correspondem às cartas topográficas elaboradas pelo Instituto Brasileiro de Geografia e Estatística (IBGE) na escala 1:50.000, referentes às folhas Mogi-Guaçu e Águas de Lindóia, bem como as cartas topográficas produzidas pelo Instituto Geográfico e Cartográfico (IGC) na escala 1:10.000, correspondente às folhas Serrote Ponte Preta e Ribeirão dos Porcos. Quanto às imagens, foram obtidas do acervo da Emplasa ${ }^{1}$ as ortofotos digitais coloridas e georreferenciadas, de 2010 bem como fotos aéreas analógicas de 1962, fornecidas pelo IGC, e escala de voo 1:25.000. Também foram utilizadas bases do DataGeo - Sistema Ambiental Paulista e IDESP - Infraestrutura de Dados Espaciais via Web Map Sservice (WMS) correspondentes ao Bens tombados Condephhat e Imagens Digital Globe de 2017.

Para compatibilizar todas as informações geográficas em SIG foi necessário atribuir o mesmo sistema geodésico de referência, procedendo-se à conversão para SIRGAS 2000, UTM 23S, quando necessário.

Inicialmente, foram georreferenciadas as cartas topográficas IGC no sistema de referência original (Córrego Alegre) para posterior conversão ao sistema geodésico em vigor, citado anteriormente. Para melhor qualidade da imagem e melhor resposta das ferramentas de vetorização semi-automática foi realizado o processamento digital com a aplicação do filtro pas-

1 Imagem Ortoretificada, decorrente dos produtos do Levantamento Aerofotogramétrico dos anos de 2010 e 2011, do Projeto de Atualização Cartográfica do Estado de São Paulo (Projeto Mapeia São Paulo), abrangendo todo o território do Estado de São Paulo. Apresentam resolução espacial aproximada de 1 metro (pixel de 1 metro) e composição colorida (RGB). São recortadas segundo a Articulação em escala 1:25000 do Sistema Cartográfico Nacional - SCN. Empresa Paulista de Planejamento Metropolitano S.A. - EMPLASA. Fonte: http://datageo.ambiente.sp.gov.br/app/?ctx=DATAGEO\#. 
sa-baixa, de modo a reduzir os ruídos e homogeneizar a imagem (quadro 1). Com a aplicação deste filtro a vetorização da das feições lineares, rios e curvas de nível, torna-se mais dinâmica e produtiva.

Todos os documentos cartográficos foram utilizados como base para georreferenciar as fotografias aéreas de 1962.

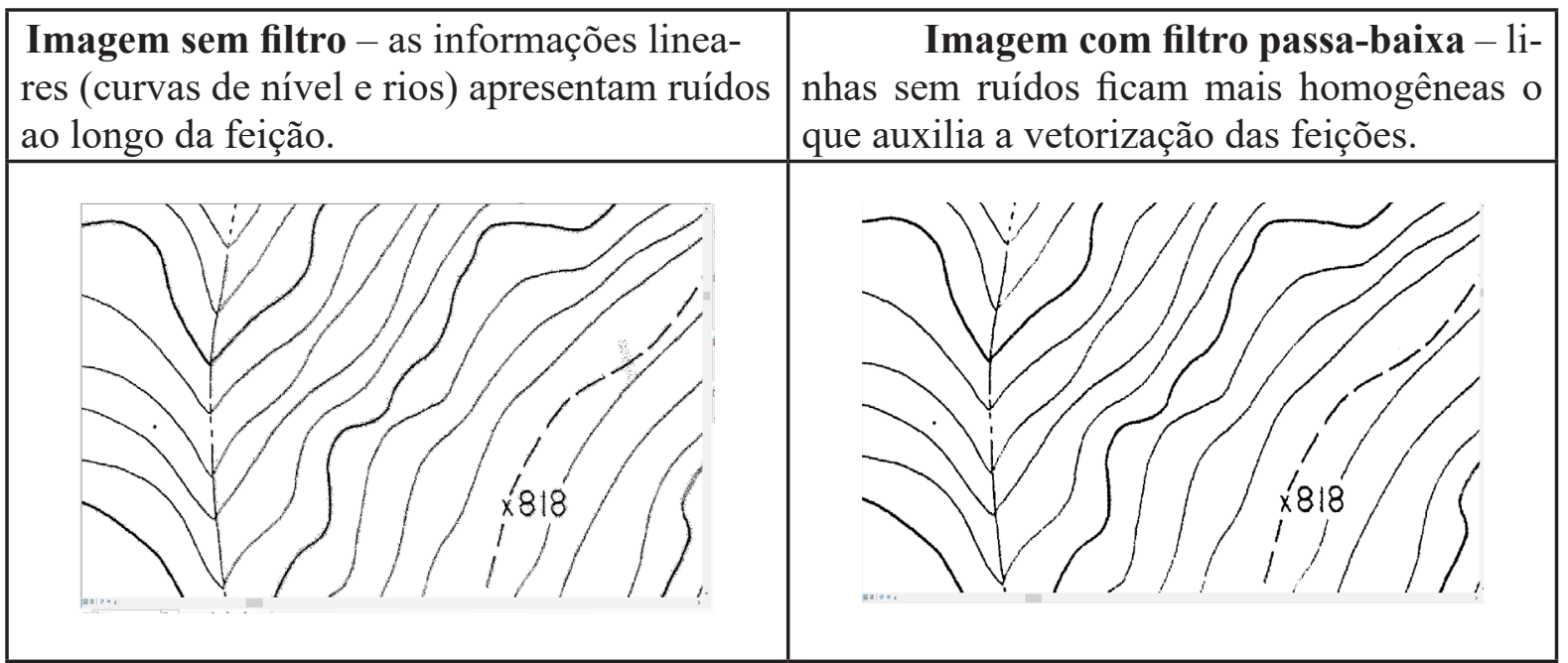

Figura 1. Exemplos de recortes da carta topográfica 1:10.000 antes e depois do processamento digital.

Após a preparação das bases cartográficas digitais foram definidas as classes de uso e cobertura da terra para a escala 1:5.000. A área mapeada corresponde à área rural abrangida pelas vertentes ou encostas voltadas para o Rio Mogi-Guaçu, desde o limite dos estados de Minas Gerais e São Paulo, à montante da barragem da usina Eloy Chaves, até a confluência do Rio Mogi-Guaçu com o Rio Eleutério. O mapeamento foi realizado diretamente no software Arcgis 10.2, por meio da interpretação visual das ortofotos coloridas de 2010 e, para atualização das informações, as classes mapeadas foram sobrepostas com a imagem de satélite Digital Globe ${ }^{2}$ do ano de 2017, via WMS (Web Map Service).

Os ambientes rurais caracterizam-se pela presença de coberturas vegetais em diversos estágios de sucessão, agriculturas, pastagens, acessos de terra, edificações esparsas e baixa densidade demográfica. Esses traços rurais são tanto naturais como culturais, com grau de naturalização intermediária entre os ambientes urbanos e naturais.

Esses atributos foram definidores das 17 classes de uso e cobertura da terra identificados

2 Acervo on-line de todas as imagens obtidas pelos satélites da constelação da operadora DIGITAL_GLOBE para a área de aproximadamente $205.900 \mathrm{Km}^{2}$ com atualizações diárias do portal, e carregadas três (03) meses após a data da tomada. DigitalGlobe - Acervo On-line de Imagens de Alta Resolução - Atualização Trimestral. Resolução: 0.60 metros. Data: 21/09/2017. Fonte: http://datageo.ambiente.sp.gov.br/app/?ctx=DATAGEO\#. Acesso em 16/11/2017. 
na área de estudo e apresentados no quadro 1. As classes foram agrupadas em duas categorias: cultural e natural. A primeira tem como principal característica a artificialidade denotando a presença da atividade humana. Observa-se traços geométricos, retilíneos, bem marcados na paisagem. A segunda configura a ausência da atividade humana, caracterizada pelas coberturas florestais nativas que exercem funções ecossistêmicas/ecológicas importantes no equilíbrio do ambiente.

\section{Quadro 1. Classes de uso e cobertura da terra}

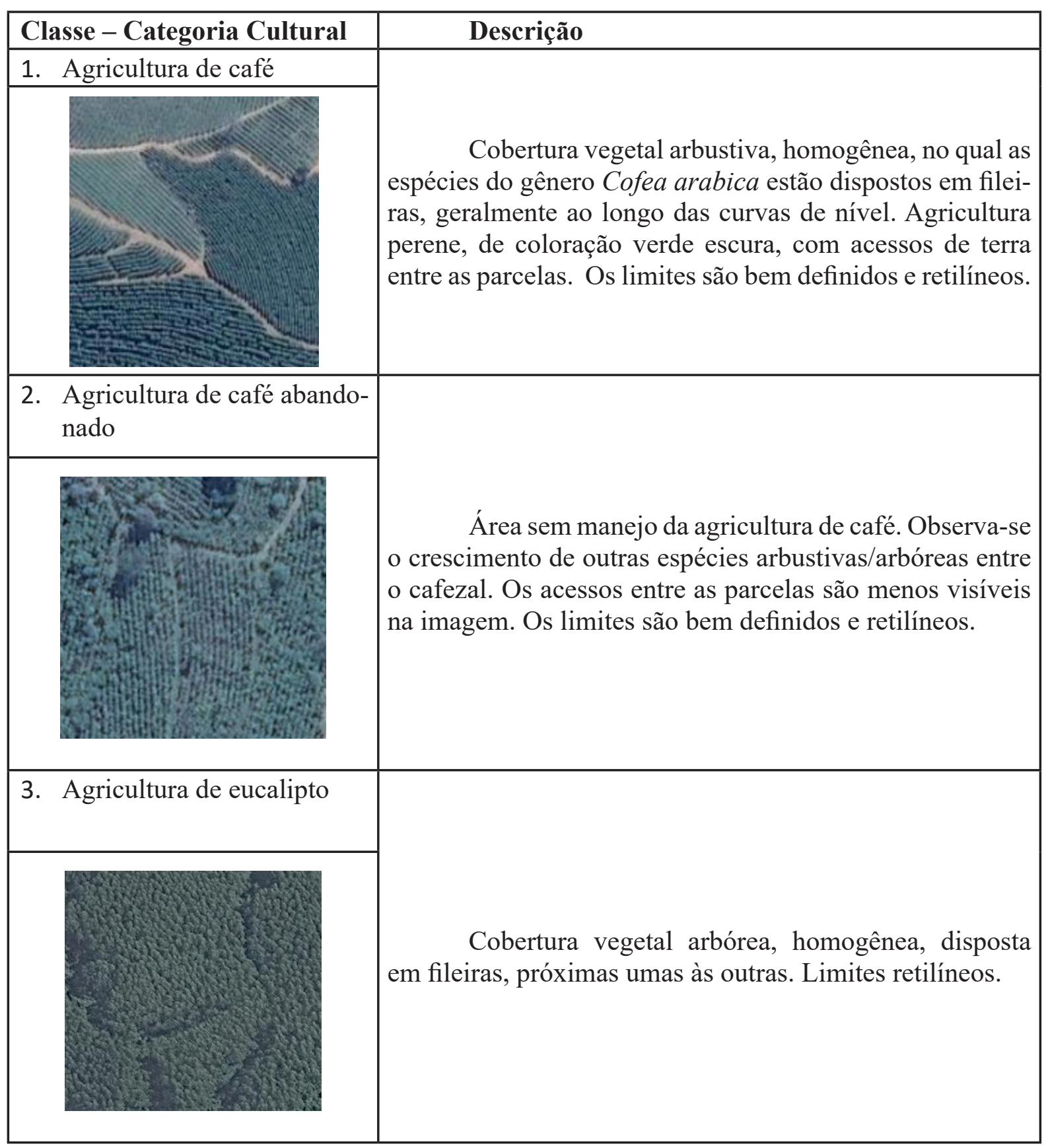




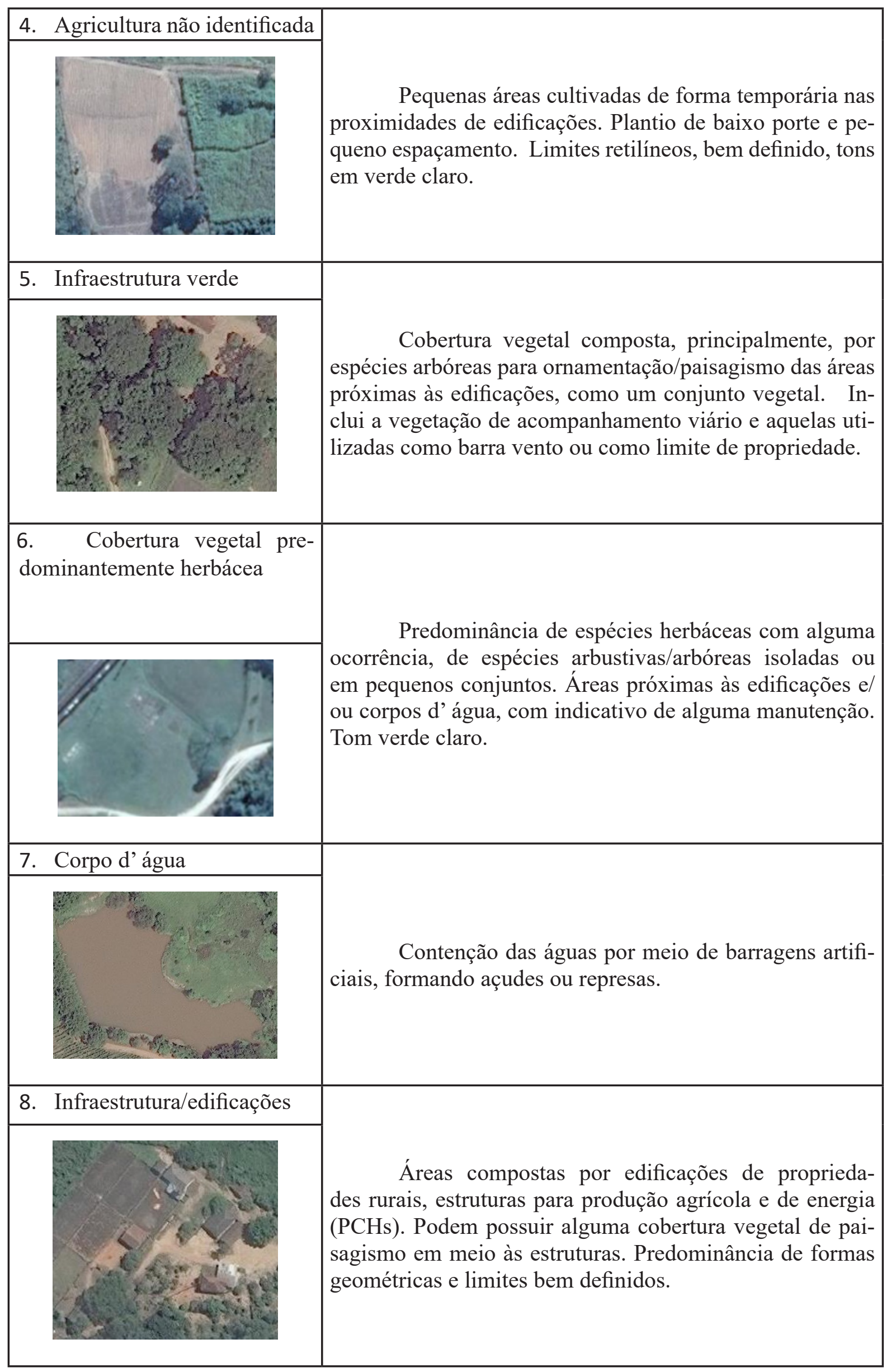




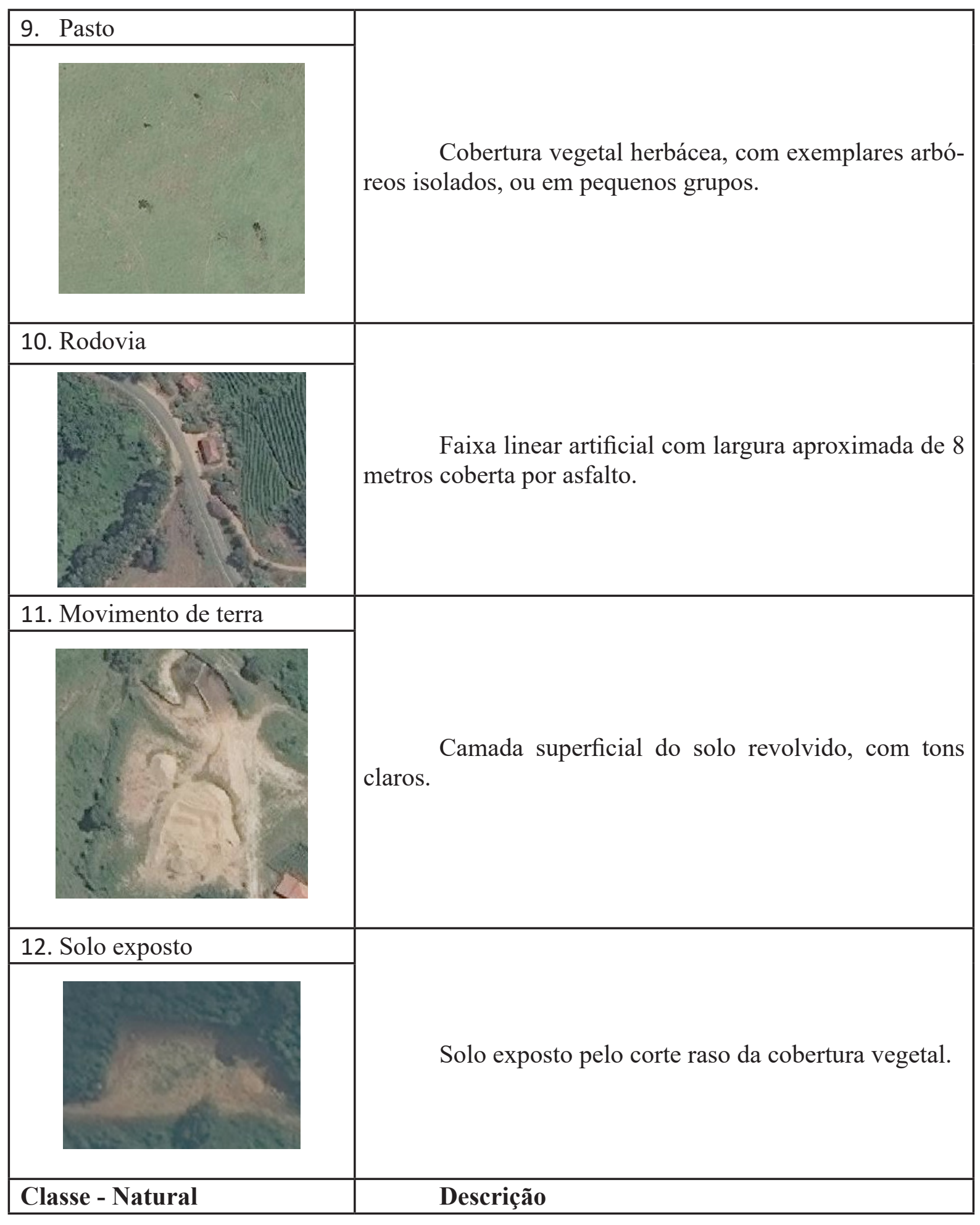




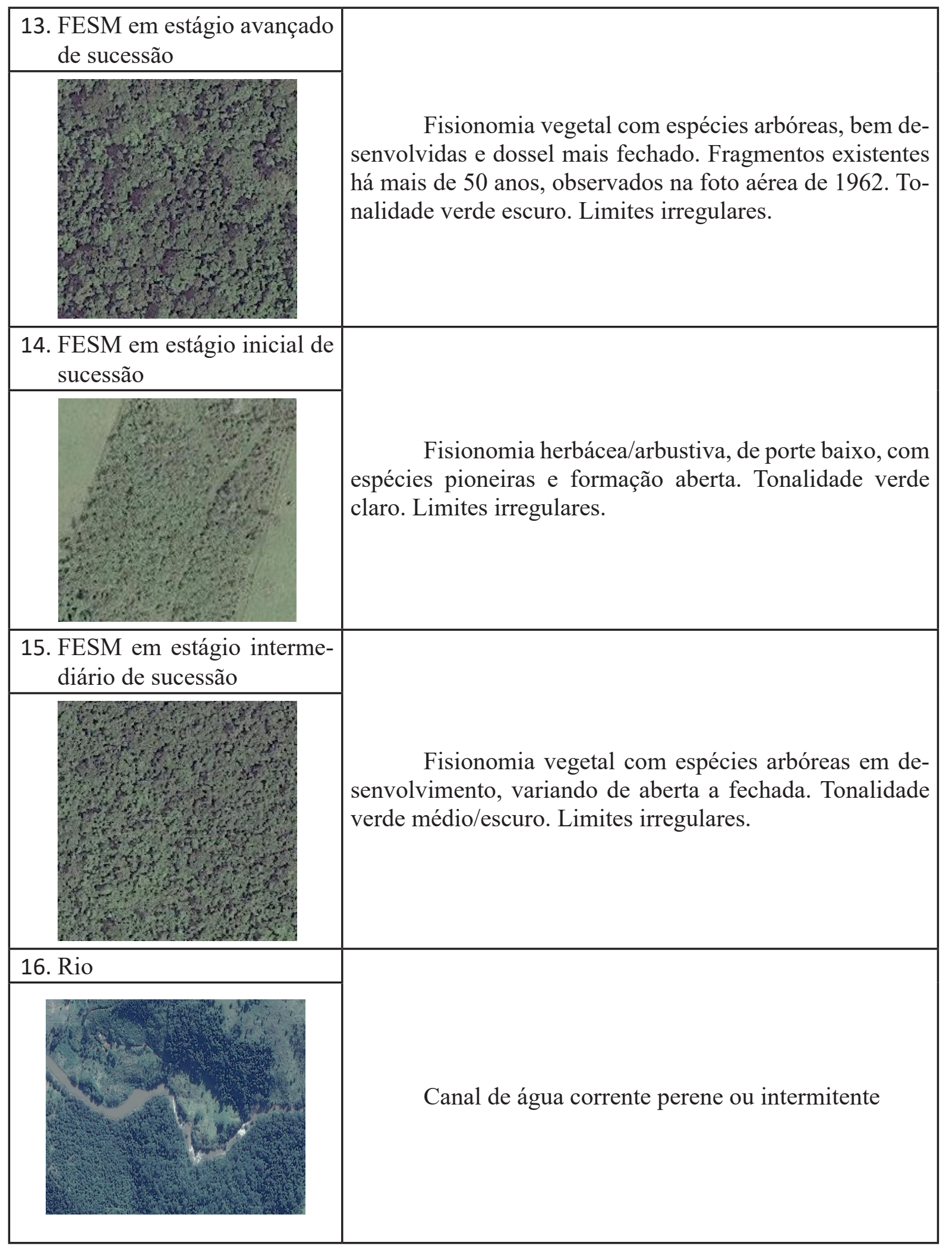




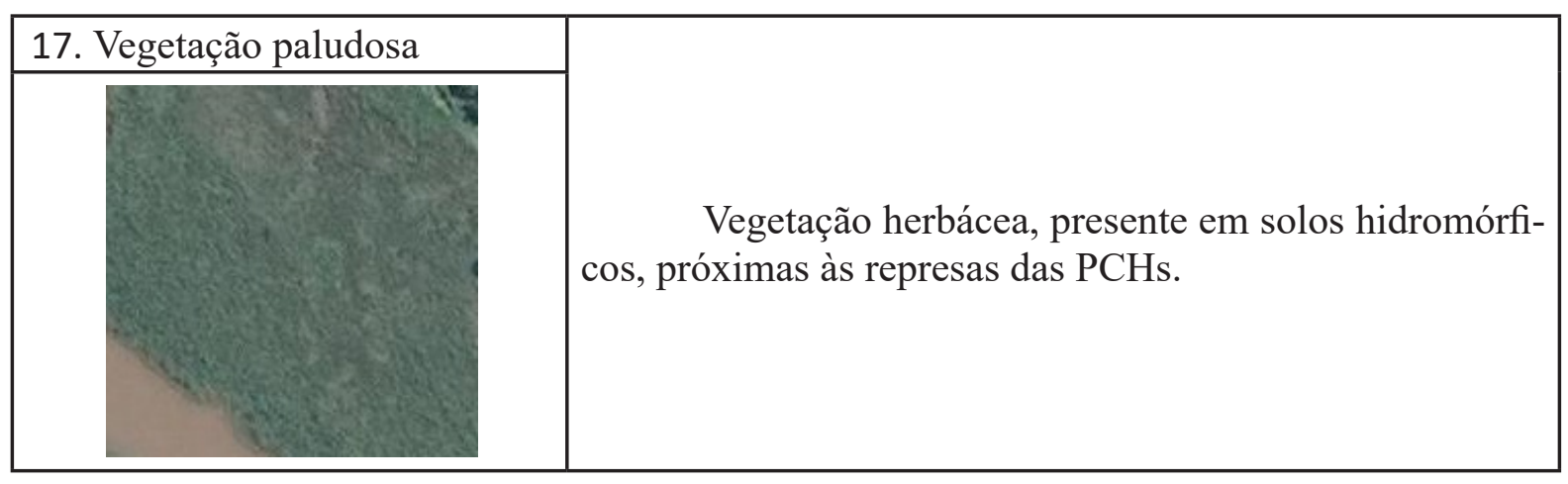

Recortes da imagem Digital Globe, 2017. Org: Giorgia Limnios, 2018.

Para LANG (2009, p. 16), “as características estruturais da paisagem são observáveis, descritíveis e quantificáveis" em três níveis de análise: manchas, classes e paisagem. Nessa pesquisa o uso das medidas será aplicado para a avaliação estrutural das classes, sem considerar a funcionalidade para as espécies.

As medidas a seguir foram escolhidas de forma a entender a composição e configuração da estrutura da paisagem rural do Espírito Santo do Pinhal com a finalidade de auxiliar no estabelecimento dos limites do patrimônio paisagístico. Os questionamentos e as descrições de cada métrica foram formulados por LANG (2009); MCARIGAL (2012). A análise da estrutura da paisagem será efetuada por meio de seis métricas analisadas nas extensões V-LATE 2.0 beta e Patch Analyst 5 para o software ArcGis 10.2, para dados vetoriais, e no software Fragstats 4, para dados raster. Para realizar o processamento das métricas de ecologia da paisagem no programa Fragstats, foi necessário converter o arquivo vetorial (formato shapafile), correspondente ao uso e cobertura da terra, para o formato imagem, na extensão .tif.

Algumas métricas foram aplicadas somente para a Floresta Estacional Semidecidual com a finalidade de apoiar na seleção das manchas mais relevantes para a composição do patrimônio.

- NP (Total de manchas por classe e total na paisagem) - Heterogeneidade - É uma medida de composição da paisagem que indica o número de manchas correspondentes a cada classe. Essa métrica avalia o grau de fragmentação da classe na paisagem. O número de manchas é maior que $1(\mathrm{NP} \geq 1)$, mas quando o valor é igual a $1(\mathrm{NP}=1)$ significa que a classe contém somente uma unidade.

$\mathbf{N P}=\mathbf{N} \mathbf{i}_{\mathbf{1}}$

Quantas manchas por classe ou no total? 
- CA (Área da Classe) - Análise da área - Medida de composição da paisagem que indica quanto dela é composta por uma classe específica. O CA se aproxima de 0 quando uma classe se torna mais rara na paisagem. $\mathrm{CA}=\mathrm{TA}$ (Área total da Classe) quando a paisagem inteira consiste em um único tipo de classe. A fórmula é definida por:

$$
C A=\sum_{j=1}^{n} a_{i j}\left(\begin{array}{c}
1 \\
10.000
\end{array}\right)
$$

A unidade de medida desse cálculo é apresentada em hectares. Qual o tamanho total da área da classe correspondente? O cálculo de área, muitas vezes, é requisito para avaliação de outras métricas da paisagem e auxilia na identificação das proporções relativas à área das classes.

- LPI (Índice da mancha maior) - Heterogeneidade - Métrica de área para medida de dominância. Corresponde à área $\left(\mathrm{m}^{2}\right)$ da maior mancha da classe dividido pela área de paisagem total (m2), multiplicado por 100, ou seja, o LPI é igual à porcentagem da paisagem composta pela maior mancha. LPI se aproxima de 0 quando a maior mancha é muito pequena e quando o LPI $=100$ significa que um tipo de mancha corresponde à toda paisagem. O resultado é dado em porcentagem que fica entre $0<\mathrm{LPI} \leq 100$. A fórmula é assim constituída:

$$
L P I=\frac{{ }_{j=1}^{a} \max \left(a_{i j}\right)}{A}(100)
$$

aij = área $\left(\mathrm{m}^{2}\right)$ mancha $\mathrm{ij}$.

$\mathrm{A}=$ área total da paisagem $\left(\mathrm{m}^{2}\right)$.

Essa métrica indica o grau de conectividade entre as entre as manchas da mesma classe. 
- MSI (Índice Médio da Forma) - Análise das formas - Essa métrica caracteriza o desvio da forma atual de uma mancha, da forma otimizada de um círculo. Por meio de uma formação de relação específica com a ajuda do número do círculo $\mathrm{Pi}(\pi)$, o valor para o índice de forma de uma forma circular pode ser estabelecido como 1, independente da área absoluta. Esse índice avalia a complexidade da forma de uma mancha por meio da comparação com uma feição padrão. A formula é representado por:

$$
\begin{aligned}
& \qquad \boldsymbol{S H A P E}=\frac{\boldsymbol{p}}{\sqrt[2]{\pi \cdot \boldsymbol{a}}} \\
& p=\text { perímetro } \\
& a=\text { área }
\end{aligned}
$$

Quão compactas são as manchas em comparação com uma circunferência de área igual? Para as classes de cobertura vegetal de origem natural, essa medida indica juntamente com o critério tamanho (área), quais manchas apresentam menores efeitos de borda.

- NNDIST (Distância ao vizinho mais próximo) - Análise de vizinhança - a distância do vizinho mais próximo é definida a partir da menor distância em linha reta entre duas manchas da mesma classe de uma reta entre os limites utilizando a geometria simples euclidiana como a menor distância em linha reta entre o ponto focal e seu vizinho mais próximo da mesma classe. Métrica utilizada para quantificar o isolamento das manchas. O resultado é fornecido em metros. A fórmula é dada por:

\section{$\mathbf{E N N}=\mathbf{H}_{\mathrm{ij}}(\mathbf{m})$}

ENN $=$ Distância euclidiana do vizinho mais próximo

Qual é a distância da próxima mancha vizinha da mesma classe? A análise das distâncias entre os fragmentos de vegetação possibilita avaliar as possibilidades de conexão entre os fragmentos que estão separados pelas menores distâncias.

- TCA/TCCA ÁREA NÚCLEO - A área núcleo representa a área efetiva do habitat, 
sem a influência do efeito de borda. A delimitação consiste na indicação do tamanho da borda, a partir do limite do fragmento em direção à área interna, sendo adotado o tamanho de 30 metros para a Floresta Estacional Semidecidual. As bordas variam em função das características abióticas locais, dos tipos de coberturas florestais e suas vizinhanças.

$$
\begin{gathered}
\text { Nucleo }=a_{i j}^{c}\left(\frac{1}{10.000}\right) \\
\text { aijc = área nucleo (m2) da mancha conforme a profundidade da borda especifi- } \\
\text { cada }
\end{gathered}
$$




\section{Capítulo 1. Paisagem}

Os diversos conceitos de paisagem como categoria na geografia, e em outras áreas do saber, apontam para o caráter polissêmico do termo. A paisagem é dinâmica e pode ter diversas dimensões no tempo e no espaço, cada olhar sobre o conjunto natural/cultural pode ter múltiplos significados e, talvez, esses sejam alguns dos principais desafios de aplicação do termo no âmbito patrimonial. Neste capítulo vamos percorrer algumas das abordagens geográficas da paisagem sem circunscrever o conceito apenas num único âmbito.

"A paisagem é o espelho de uma civilização". Assim definiu o geógrafo francês Pierre Monbeig ao olhar as marcas culturais em diversas paisagens européias ${ }^{1}$ e brasileiras. MONBEIG, 2004, p. 109). Nas áreas mais interioranas do território paulista prevaleceu a paisagem natural, dominada pelo conjunto de formas, cursos d' água e coberturas vegetacionais exuberantes, constituídas pelas fitofisionomias das Matas Atlânticas, pelos cerrados e matas de galeria, até meados do século XIX. Em seguida, a paisagem natural ${ }^{2}$ foi substituída pela paisagem cultural, dominada pelo café e algodão, que novamente se modificou no tempo, constituindo diversas paisagens que refletem outras formas, técnicas e estruturas sociais sobre um mesmo suporte natural. Como as marcas culturais de grupos sociais se transformam, as paisagens também possuem trajetividade (MARIA, 2016). Assim os diversos conceitos de paisagem constituem distintas "geografias da paisagem"

Besse $(2006)^{3}$ apresenta resumidamente algumas definições de paisagem que podem ser atribuídas a diversas áreas do saber: a) uma representação cultural (principalmente informada pela pintura); b) como um território produzido pelas sociedades ao longo de sua história; c) como um complexo sistêmico que articula os elementos naturais e culturais em uma totalidade objetiva; d) como um espaço de experiências sensíveis rebeldes à mais diversas formas possíveis de objetivação e e) um sítio ou projeto ou um contexto de projeto.

Retrospectivamente a landschaft (landschap, paese) se define pelo seu sitium, ou seja, ao mesmo tempo por uma posição e por uma vizinhança características" [...] A landschaft é de início um lugar que se define por vizinhanças,

$1 \mathrm{O}$ geógrafo se referiu às paisagens das regiões geográficas das terras baixas da Holanda e Flandres na Bélgica e França.

2 A dicotomia paisagem natural e cultural usada em muitos textos geográficos de uma geração de geógrafos do século XX, foi mantida nesta passagem do texto, pois os autores referidos assim a utilizaram. Mais adiante no texto assumimos a visão contemporânea de que a paisagem é um fato cultural que contém o natural (Meneses, Ulpiano, 2002)

3 BESSE, Jean-Marc. Las cinco puertas del paisaje: ensayo de uma cartografía de las problemáticas paisajeras contemporâneas. In: MADERUELO, J. "Paisaje y Pensamiento". Serie: $\mathbf{H}^{\mathrm{a}}$ del Arte y de la Arquitectura, ABADA Editores. Madrid, España. 2006. 
humanas e naturais, que se pode designar como objetivas, e que podem assim ser cartografadas. Além da mera consideração de sua posição relativa, a Landschaft se define também por um conjunto de propriedades, naturais e humanas, cujo inventário constitui sua qualidade ou natureza próprias (BESSE, 2006, p. 21)

Paisagem (landschaft) designa aspectos concretos da realidade geográfica, aqueles que se descrevem ao se percorrer uma região. Seu emprego científico pode diferir pouco do sentido pelo qual é utilizado na linguagem comum (TRICART, 1979).

Para Santos (2008), tudo aquilo que nós vemos, o que nossa visão alcança, é a paisagem. Esta pode ser definida como o domínio do visível, aquilo que a vista abarca. Não é formada apenas de volumes, mas também de cores, movimentos, odores, sons etc.

Nesse sentido a paisagem abrange uma parcela da totalidade espacial, ela é um fragmento de um complexo maior e esta perspectiva de horizonte significa para Besse (2006), a "ausência de totalização" possibilitando "a experiência da proximidade das coisas" Ainda, para este autor, mesmo a paisagem sendo

uma dimensão do visível, é o resultado, o efeito, ainda que indireto e complexo, de uma produção. A paisagem é um produto objetivo, do qual a percepção humana só capta, de início, o aspecto exterior. Há como que um "interior” da paisagem, uma substância, um ser da paisagem que só deixa ver seu exterior. É aliás, isto que dará, aos olhos de certos geógrafos, o limite da abordagem paisagística. (BESSE, 2006 p.65)

Assim, a interpretação de uma paisagem para ser compreendida deve ir além do visível, há um cenário invisível, longe e vasto que estimula o imaginário do observador pelo desconhecido, a descobrir outros lugares e ir mais além do que se pode ver.

No campo da representação espacial da paisagem exterior e interior são objetos da cartografia. Neste sentido há sempre um desafio, mapear o visível buscando traduzir a sua complexidade, nem sempre objetiva para os mapas.

Por essa razão a representação cartográfica do mundo e dos lugares ampliou a visão sobre a paisagem e com o advento das fotografias aéreas e imagens de satélite foi possível expandir os limites espaciais e também temporais para além do horizonte visível, mas não do sensível. A extensão da paisagem ganha uma pluralidade escalar com vários recortes possíveis do observador.

Considerado o fundador da geografia cultural nos Estados Unidos, Sauer analisa a paisagem morfologicamente, existindo uma preocupação em investigar como a cultura humana, analisada através de seus artefatos materiais, transforma essa paisagem (RIBEIRO, 2007). Carl 
Sauer (1925) apontou que não podemos formar uma ideia de paisagem a não ser em termos de suas relações associadas ao tempo, bem como suas vinculações ao espaço. Ela está em um processo constante de desenvolvimento ou dissolução e substituição [...] Na geografia o estudo da paisagem baseia-se, na realidade, na união dos elementos físicos e culturais nesse constante movimento. O conteúdo da paisagem é encontrado, portanto, nas qualidades biofísicas da área que são importantes para a sociedade e nas formas do seu uso, em fatos de base física e fatos da cultura humana.

Dente os enfoques desta análise não linear do conceito que estamos apresentando destacamos Milton Santos (2006), que considera a paisagem sempre heterogênea, pois é formada pelo conjunto de formas naturais e artificiais materializadas em momentos históricos diferentes e, ressalta, que o termo não é sinônimo de espaço, uma vez que este representa essas formas mais a dinâmica social, ou seja, "o espaço contém o movimento", condição que o autor considerou para separar os dois vocábulos em categorias distintas.

A paisagem é o efeito e a expressão evolutiva de um sistema de causas também evolutivas: uma modificação da cobertura vegetal ou uma mudança nos mecanismos da produção agrícola se traduzem nas aparências visíveis (BESSE, 2006). Essa compreensão da ideia de paisagem exprime o quanto esta categoria de investigação está sujeita à transformações, decorrentes da dinâmica das condições naturais e sociais. Indica tempo e movimento, intrínseco à realidade dos lugares.

O geógrafo Augustin Berque (1984) procurou compreender a lógica da existência da paisagem pela relação desta com a sociedade. Assim, a paisagem é ao mesmo tempo marca, "pois expressa uma civilização e matriz porque participa dos esquemas de percepção, de concepção e de ação - ou seja, da cultura - que canalizam, em um certo sentido, a relação de uma sociedade com o espaço e com a natureza e, portanto, a paisagem do seu ecúmeno" (BERQUE, 1998 p. 85). Para o autor deve-se entender a paisagem sob duas formas: primeiro, como ela é vista e assimilada

por uma consciência e valorizada por uma experiência, julgada por uma estética e uma moral, gerada por uma política etc. e, segundo, como determinadora (matriz) do olhar, da consciência, da experiência, da estética, da moral, da política etc., pois a paisagem é repleta de sentido (cultura), ou seja, "de significado e de tendência evolutiva." [...] Portanto, a paisagem e o sujeito (coletividade) são plurimodais (passiva-ativa-potencial etc.) e estão co-integrados em um conjunto unitário, que se autoproduz e se auto-reproduz. (BERQUE, 1984 p.86)

Quando Olivier Dollfus fez suas observações acerca dos escritos de Augustin Berque intitulado "Paisagem-Marca, Paisagem-Matriz: elementos da problemática para uma geografia cultural" o autor afirma que o conceito de paisagem é impreciso e assim deve permanecer, pois 
as paisagens são "expressões próprias de uma sociedade ao longo do tempo" Essa imprecisão está relacionada com a complexidade dos fatos paisagísticos, ou seja, cada lugar apresenta uma história e uma composição natural e cultural únicas. Diante dos diversos significados do termo e das subjetividades de cada olhar, Tricart (1979) também reconheceu sua imprecisão, devido à falta de necessidade em definir na paisagem, os elementos que o constituem. Mas o conceito científico não deve ser impreciso, porque abrange uma realidade que reflete profundas relações entre seus componentes.

Para Cosgrove (1989) a paisagem está intimamente ligada a uma nova maneira de ver o mundo como uma criação racionalmente ordenada, designada e harmoniosa. Nesta dimensão a estrutura e mecanismo são acessíveis ao cognitivo humano. Agem como orientação para as ações humanas que se organizam no sentido de alterar o meio ambiente, também para melhorar alguns aspectos. Neste sentido, paisagem é um conceito complexo e cujas implicações o autor especificou em três aspectos:

- "Foco nas formas visíveis de nosso mundo, sua composição e estrutura espacial”;

- "Unidade, coerência e ordem ou concepção racional do meio ambiente";

- "Ideia de intervenção humana e controle das forças que modelam e remodelam nosso mundo."

A paisagem não se cria de uma só vez, mas por acréscimos, substituições, pois como já dito acima a lógica pela qual se fez um objeto no passado era a lógica da produção daquele momento. Portanto uma paisagem é uma escrita sobre outra, é um conjunto de objetos que têm idades diferentes, é uma herança de muitas temporalidades (SANTOS, 2008).

Neste sentido do tempo a paisagem é sempre uma herança natural e cultural. Na verdade, ela é uma herança em todo o sentido da palavra: "herança de processos fisiográficos e biológicos, e patrimônio coletivo dos povos que historicamente as herdaram como território de atuação de suas comunidades". (Ab' SABER, 1977, p. 19)

Como a paisagem carrega marcas de diferentes tempos é possível conhecer ou estimar sua idade, quer pelas características físicas e/ou bióticas, quer pelos materiais ou objetos característicos de determinadas técnicas. No caso dos componentes artificiais referenciados por SANTOS (2002) a paisagem pode ser datada, exatamente, por intermédio das permanências de técnicas: de produção, transporte, comunicação, entre outros. É importante ressaltar que as permanências podem estar no imaginário social quando um aspecto da sociabilidade e da subjetividade são guardados na memória. Nesse sentido as técnicas são um fenômeno histórico e a memória um fenômeno social. É possível identificar o período, o momento de sua "origem"4

4 A ideia de origem é muito relativa, pois o tempo de partida de um artefato técnico pode não ser tão exatamente mensurável. Por exemplo: podemos ter o edifício da indústria têxtil datado por sua construção, mas a origem da ideia, da política e da técnica que o produziu pode não ser tão precisamente datado. Além disso o efeito na paisagem pode não ter registro preciso na memória dos sujeitos envolvidos nesta paisagem. O edifício da indústria pode 
e transformação. A datação dos objetos pode até ser objetiva. A data pode, no entanto, ter uma dimensão simbólica, pois os sujeitos guardam o tempo em sua trajetória de vida, por exemplo a memória dos trabalhadores das PCHs.

Essa datação é possível à escala de um lugar, quanto à escala do mundo. Como herança o lugar está no mundo assim como o mundo está no lugar.

$\mathrm{Na}$ visão sistêmica, a paisagem também pode ser entendida sob o enfoque da organização, ordem e hierarquia, que considera os elementos de suporte e cobertura na escala espacial, de acordo com o objetivo da pesquisa, conforme proposto por MONTEIRO (2001) que considera a paisagem como

Entidade espacial delimitada segundo um nível de resolução do geógrafo a partir dos objetivos centrais da análise, de qualquer modo, sempre resultando da interação dinâmica, portanto instável dos elementos de suporte e cobertura (físicos, biológicos e antrópicos) expressa em partes delimitáveis infinitamente, mas individualizadas através das relações entre eles, que organizam um todo complexo (sistema), verdadeiro conjunto solidário e único, em perpetua evolução (MONTEIRO, 2001, p. 39)

Neste breve percurso conceitual percebe-se que as definições de paisagem na geografia estabelecem relações entre os atributos naturais e as ações humanas no tempo e no espaço constituindo um amplo leque de possíveis abordagens de pesquisa. Seja na leitura dos processos (paisagem sistema) seja nas leituras do tempo que marca as trajetórias sociais de apropriação, vinculação afetiva e simbólica e transformação. Esses diversos olhares da paisagem na geografia revelam o quanto esse conceito é cultural e multitemporal, possibilitando vários caminhos investigativos.

conter um tempo no uso como edifício industrial, mas pode ser lido por diferentes gerações numa temporalidade com significados distintos. 


\section{Ecologia de paisagem}

Uma paisagem qualquer possui sempre uma compartimentação topográfica, uma estrutura superficial, uma cobertura vegetal específica, assim como determinada potencialidade em termos ecológicos. Em face das condições climáticas habituais da área, toda paisagem tem uma espécie de fisiologia particularizada. E, evidentemente, qualquer perturbação no ritmo e na intensidade dos processos fisiológicos e ecológicos poderá ser irreversível em termos de funcionalidade, fertilidade e produtividade". Aziz Ab' Saber (1969). Geografia e Planejamento" Revista de História, São Paulo, v. 39, n. 80, p. 257-272, 1969.

As perturbações do processo produtivo alteraram profundamente as paisagens brasileiras. Esse processo histórico gerou uma fragmentação de habitats que tornaram os fluxos biológicos difíceis para muitas espécies. Cientificamente as pesquisas sobre esse processo avançaram muito no entendimento da fragmentação, o que levou ao fortalecimento e ressurgimento da Ecologia de paisagens.

Quando as primeiras referências sobre ecologia da paisagem surgiram, no final da década de 1930, a ciência geográfica foi o principal campo do conhecimento do qual o geógrafo alemão Carl Troll se apoiou para desenvolver o conceito que integra a paisagem e a ecologia. Para este autor a ecologia da paisagem "é o estudo da totalidade espacial e visual" que forma um complexo holístico inteiro de causa e efeito entre as comunidades vivas e suas condições do meio físico que predominam em um setor da paisagem (TROLL, 1971 apud NAVEH; LIBERMANN, 1993 p.4). Essa definição também inclui o saber relacionado ao conceito de ecossistema, apresentado por Tansley, em 1935, do qual trata das interações e dinâmicas que ocorrem entre os componentes bióticos e abióticos, na atualidade o conceito foi ampliado e inclui as ações humanas. De acordo com Metzger (2001), três pontos caracterizam a abordagem geográfica: "a preocupação com o planejamento da ocupação territorial, através do conhecimento dos limites e das potencialidades de uso econômico de cada unidade da paisagem ${ }^{5}$; o estudo de paisagens fundamentalmente modificadas pelo homem - as paisagens culturais; e a análise de amplas áreas espaciais".

Muitas são as abordagens também neste campo. Vários autores consideram que a abordagem ecológica teve maior desenvolvimento a partir da década de 1980, em virtude dos produtos resultantes do sensoriamento remoto, onde o principal suporte foram as análises espaciais

5 Na visão do autor a unidade da paisagem é espaço de terreno com características comuns 
das imagens do satélite da série Landsat ${ }^{6}$, e as tecnologias computacionais que associadas as análises geoestatísticas (METZGER, 2001; LANG et al., 2009; TURNER, 2001). Forman e Godron (1986, p. 595) definiram ecologia de paisagem como o "estudo da estrutura, função e dinâmica em uma área heterogênea composta de ecossistemas interativos". A estrutura se refere às relações espaciais entre os ecossistemas ou elementos distintivos presentes. Estes autores propuseram inicialmente uma taxonomia muito simples de classificação espacial formada por uma Matriz, Mancha ou fragmento e Corredor). A esta estrutura relacionaram a ideia de fluxo, mais especificamente a distribuição de energia, materiais e espécies em relação ao tamanho, formas, tipos e configurações dos ecossistemas. Esta conceituação de estrutura e fluxo gerou uma ampla gama de considerações quanto aos processos. Lang $(2009$, p. 107) sugere que a estrutura horizontal de uma paisagem corresponde a um padrão específico, ou a sua fisionomia originária de um determinado ordenamento ou sequência de unidades homogêneas da paisagem. Em geografia o estudo dessas unidades homogêneas gerou uma produção voltada ao planejamento (CHAVEZ, 2005; MONTEIRO, 2001).

Metzger (1998) trabalha as relações horizontais da estrutura pela área, forma e disposição espacial das unidades interativas que interferem no habitat das espécies. Para Forman e Godron (1986, p. 11) a funcionalidade dos habitats se refere as possibilidades de interações entre os elementos da paisagem (Matriz, mancha e corredor) na qual ocorrem os fluxos de energia, trocas de materiais e deslocamento das espécies entre os ecossistemas. A dinâmica refere-se à alteração da estrutura e função do mosaico ecológico no tempo, ou seja, da paisagem modificada na trajetória do tempo.

Os elementos que compõem a paisagem são representados por um modelo conhecido como mancha-corredor-matriz ${ }^{7}$ (Figura 2). Sob este modelo simplificado, os três principais elementos paisagísticos são tipicamente reconhecidos e a extensão e configuração desses componentes define o padrão ou mosaico da paisagem (MCGARIGAL, 2012). A definição do padrão ou mosaico paisagístico está vinculada à escala espacial adotada pelo observador, ao recorte territorial e à localização geográfica. Quanto maior for a extensão territorial da paisagem analisada, em imagens de satélite ${ }^{8}$, mais homogênea será. Quanto menor for a extensão territorial da paisagem ${ }^{9}$, mais unidades poderão ser identificadas, principalmente se o suporte for fotografias aéreas e imagens de alta resolução espacial, evidenciando maior heterogeneidade. Portanto, uma mancha em uma determinada escala espacial pode configurar uma matriz em outra escala. As escalas do observador são igualmente importantes, pois a percepção do ambiente pela visão de uma espécie aquática, terrestre ou aérea determina matrizes distintas.

\footnotetext{
6 A série de satélites Landsat é o sistema de observação da Terra mais antigo dos Estados Unidos e, desde 1972, gera dados e imagens de todo globo terrestre. Cada novo satélite lançado, novas melhorias foram desenvolvidas para geração de imagens com melhor resolução espectral, espacial e cobertura terrestre.

$7 \quad$ Apresentado em 1986 por Forman \& Godron.

8 Trata-se de escalas de baixa ou média resolução; escala espacial pequena, por exemplo 1:1.000.000, $1: 500.000$

$9 \quad$ Trata-se de escala grande, por exemplo, 1:10.000, 1:5.000
} 


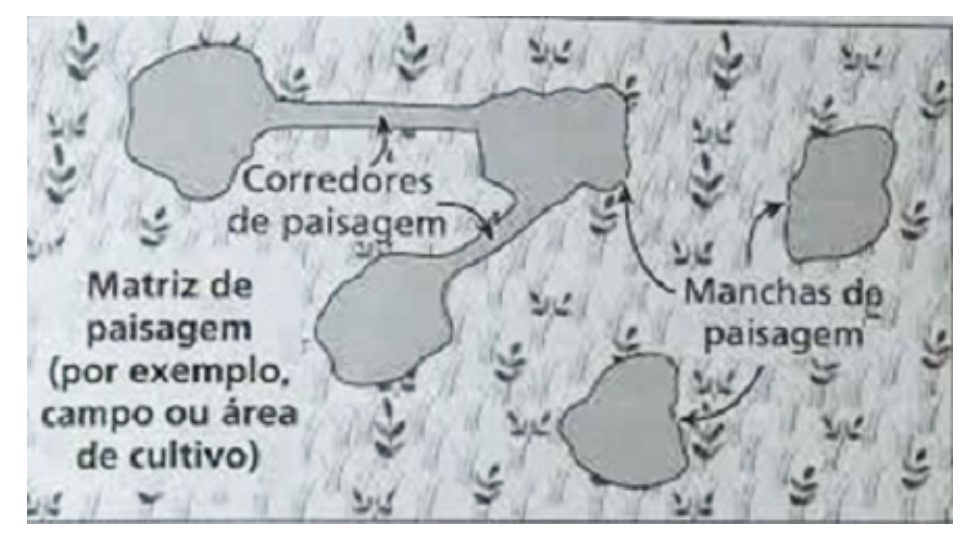

Figura 2 - Principais elementos da paisagem: mancha, corredor e matriz. Fonte: Odum, 2007, p. 401

Em seguida vamos explanar sobre as classes dessa taxonomia apresentadas por Forman e Godron (1986). As Manchas são áreas não lineares que se diferenciam na estrutura e/ ou composição em relação ao seu entorno. Variam em tamanho (grande ou pequeno), forma (mais ou menos arredondada), tipo (natural ou cultural) e características (idade, composição etc.), podendo apresentar alta ou baixa qualidade do remanescente de habitat em relação aos recursos disponíveis para as espécies. São elementos encravados na matriz que propiciam funções ecológicas de habitat: suporte, abrigo, fonte de alimentação e reprodução para as espécies ou mesmo utilizados como trampolins entre manchas. No mosaico da paisagem elas também são consideradas como "ilhas" e as relações entre esses fatores (tamanho e isolamento) foram considerados nos estudos de McArthur e Wilson, na década de 1960, ao propor a teoria da biogeografia de ilhas. Este modelo de estudo da paisagem também é conhecido como modelo de ilhas. O modelo ilhas refere-se à combinação área x espécie e distância x tamanho (Figura 3) 


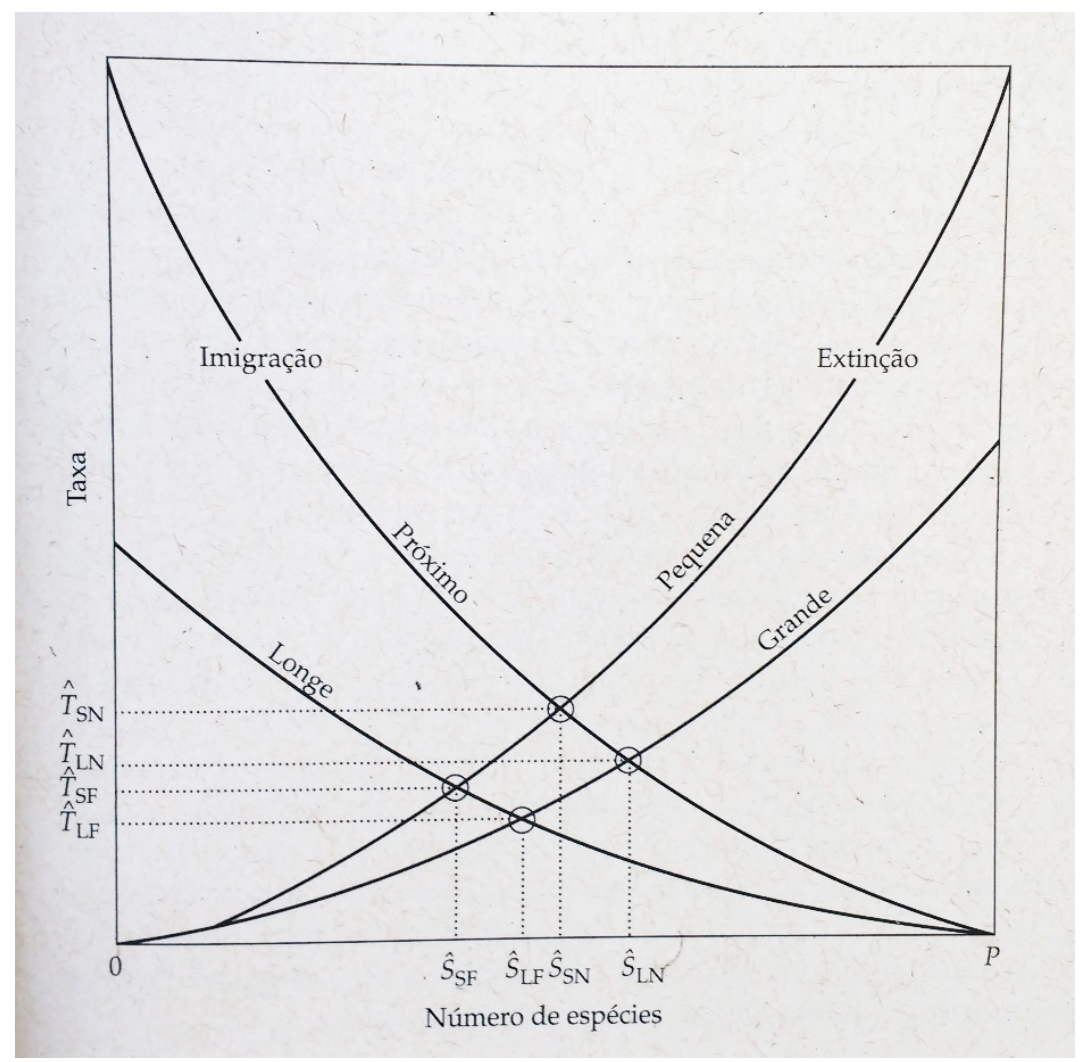

Figura 3 - Teoria da biogeografia de ilhas (MacArthur e Wilson). Nesta teoria o número de espécies em uma ilha (fragmento natural) é determinado pelo equilíbrio entre as taxas de emigração e extinção e a disponibilidade de nicho ecológico. Quatro pontos de equilíbrio são mostrados no gráfico, representando as combinações entre ilhas grandes e pequenas, próximas ou distantes do continente. Fonte: ODUM, 2007; BROWN, 2006.

Os Corredores da paisagem representam estruturas lineares que diferem da matriz em ambos os lados e, com frequência, conectam tanto de forma natural como artificial duas ou mais manchas. Naturalmente, os corredores são representados por coberturas vegetais remanescentes e pelos cursos d'água, caracterizados pela curvilinearidade de seus limites. Culturalmente, são constituídos por canais, linhas de transmissão de energia, estradas, ferrovias, vegetação plantada que tem como principais funções habitat para algumas espécies, um habitat de deslocamento, uma barreira ou filtro entre áreas e uma fonte de efeitos biofísicos na matriz circundante. Também podem ter efeitos negativos na paisagem como a propagação de fogo, doenças e maior exposição de espécies à predação. Além das funções apresentadas, McGarigal (2012: p. 9) aponta a possibilidade para três tipos diferentes de corredores estruturais:

"1) Linhas de corredores, em que a largura do corredor é estreita demais para permitir o desenvolvimento de condições ambientais internas;

2) Faixas de corredores, nos quais a largura do corredor é ampla o suficiente para permitir o desenvolvimento de condições internas; 
3) Corredores de fluxo, que são uma categoria especial ${ }^{10}$."

O mesmo autor sugere 4 tipologias funcionais para os corredores. São elas:

1. Corredor habitat- Paisagem linear que cumpre funções de sobrevivência, tais como facilitadora da natalidade, migrações temporárias, entre outros. Os corredores que funcionam como extensão de habitat aumentam as possibilidades de conectividade.

2. Corredor facilitador de movimento - Paisagem linear com funções semelhantes do Corredor habitat quanto a sobrevivência e conectividade, exceto para o parâmetro natalidade.

3. Corredor Filtro ou Barreira - Paisagem linear que dificulta o deslocamento das espécies. Funcionam como barreira seletiva, permitindo a conectividade para algumas espécies e não todas, exemplo uma represa, um rio etc.

4. Fonte de efeitos abióticos e bióticos na matriz circundante - Paisagem linear que modifica o efeito de inputs de energia, nutrientes e espécies causando efeitos na Matriz ao redor, por exemplo uma rodovia de grande porte, linhas de transmissão.

A paisagem é composta por vários tipos de elementos. A matriz é caracterizada pelo elemento mais extenso e conectado da paisagem, desempenhando o papel dominante no funcionamento (Forman; Godron, 1986). Nela estão incluídos os diferentes tipos de manchas e os corredores.

Existem, essencialmente, três critérios por meio das quais a matriz é determinada e pode ser descrita (Forman; Godron, 1986).

- Área: quando a classe da paisagem é mais extensa que as demais, recobrindo mais que $50 \%$ da área;

- Grau de conectividade;

- Controle sobre a dinâmica da paisagem: quando a classe exerce maior influência na paisagem do que qualquer outra.

Os padrões espaciais e processos ecológicos de uma determinada matriz resultam das interações existentes entre os elementos da paisagem que são influenciados, direta e indiretamente, pelas condições físicas e biológicas e pela unidade vizinha, podendo criar barreiras para algumas espécies ou facilitar o fluxo biológico entre os distintos ambientes. Estes efeitos de vizinhança foram definidos como efeito de borda. A borda é uma extensão dos efeitos de trocas

10 São corredores em que efetivamente se conhece a funcionalidade para as espécies. 
que ocorrem entre os elementos da paisagem: matriz x mancha; matriz x corredor, por exemplo. Os ambientes nas bordas são bons exemplos de zonas de transição originado pela influência mútua dos vizinhos, porém apresentam características variadas de distintos parâmetros, tais como do meio físico (luminosidade, umidade, temperatura, ventos) e biológicos (incursão de espécies adaptadas a condição de transição) e composição próprias. Neste enfoque ecológico os atributos naturais das paisagens, em especial as coberturas vegetais, têm maior ênfase nos estudos que envolvem a conservação da biodiversidade, o manejo dos recursos naturais e em algumas abordagens da sustentabilidade das paisagens.

A ecologia de paisagens pode ser assim uma oportunidade de combinação de uma análise espacial da geografia articulada aos estudos ecológicos. A problemática central é o efeito da estrutura da paisagem nos processos ecológicos. A ecologia de paisagens pode ser assim entendida como uma ecologia de interações espaciais entre as unidades da paisagem. (METZGER, 2001, pág. 5). Sartorello (2014) propõe uma aproximação entre ambas (Figura 4).

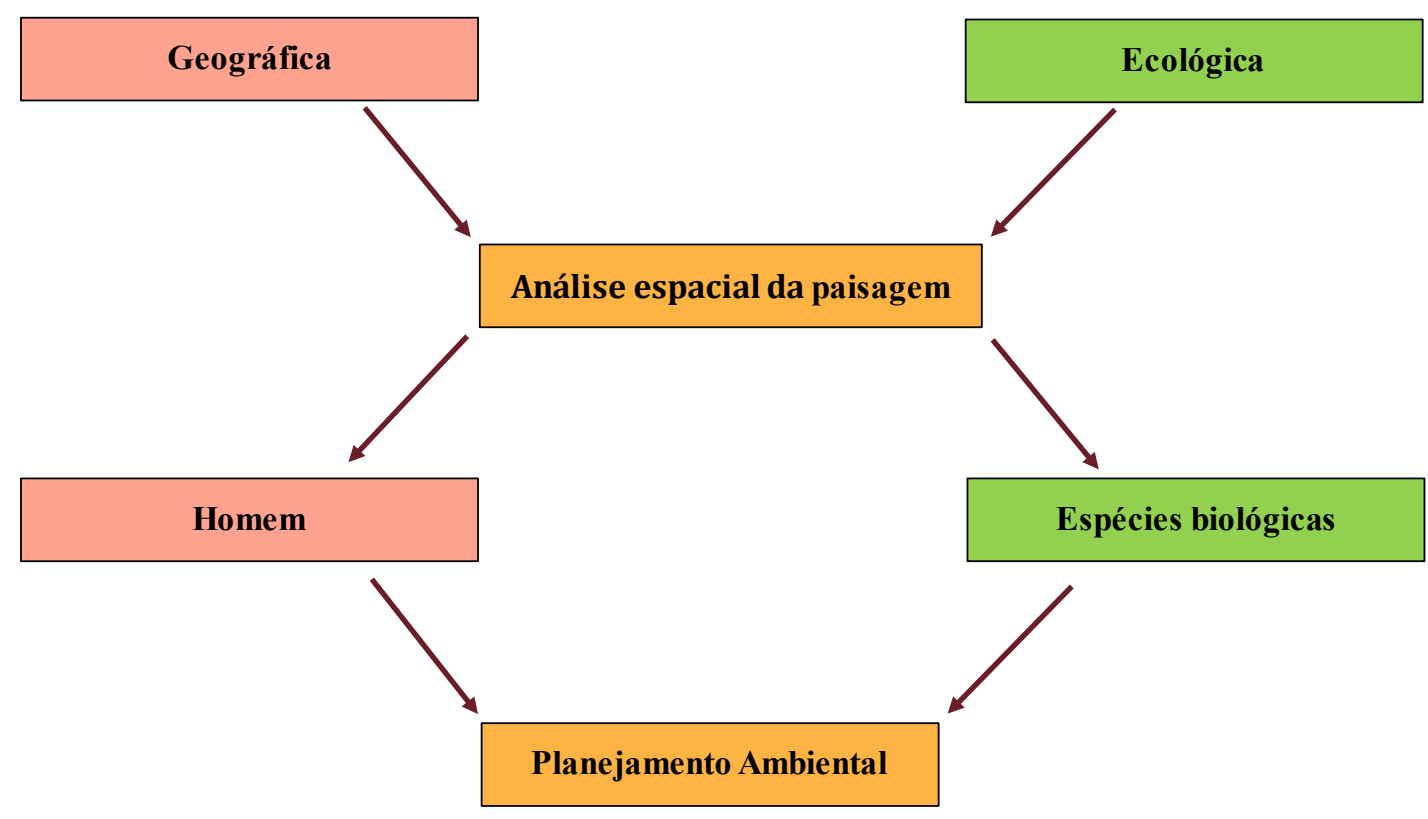

Figura 4 - Visões da Ecologia da Paisagem. Fonte: Sartorello, 2014, comunicação pessoal. 


\section{Ecologia da paisagem - uma discussão}

A paisagem é um continuum espacial, mas não o é nos elementos constituintes [...] ela reflete essa dialética com princípios de unidade e diversidade. Aliás são esses próprios princípios que, paralelamente, comandam as características e, sobretudo o funcionamento dos ecossistemas. (TRICART, 1979, p.25).

A busca pelo entendimento do funcionamento de sistemas de paisagem tem sido uma oportunidade para vários estudos que auxiliam as análises espaciais para melhor compreender a dinâmica da unidade e diversidade dos atributos interagentes numa paisagem.

Cada espaço concreto, cada paisagem, comporta alguns elementos comuns, que são os princípios da homogeneidade, que se constituem em apenas uma parte de suas características. Retomando a ideia sistêmica de todo-parte esses princípios, esse espaço encerra também aspectos diferentes que respondem a um princípio contrário: de heterogeneidade. Mas o arranjo desses elementos pode obedecer a regras, a leis, pois formam uma totalidade. (TRICART, 1979, p. 29-30).

Dentre os princípios ecológicos estabelecidos por Forman (1995) existem aqueles considerados prioritários no planejamento da paisagem: estabelecimento ou manutenção de grandes manchas de vegetação, amplos corredores de vegetação, conectividade para o fluxo de espécies e pequenos corredores e manchas de vegetação em meio às paisagens urbanizadas.

Essas grandes premissas auxiliam os desenhos de conservação. Geralmente as maiores manchas de vegetação proporcionam maior diversidade de ambientes que favorecem maior oferta de recursos para a sobrevivência dos indivíduos, possibilitando maior riqueza de espécies. Em grandes fragmentos, como por exemplo o Parque Estadual da Serra do Mar, protegido também como Patrimônio Natural Tombado, as taxas de extinção podem ser menores, assim como os efeitos de borda no interior do fragmento. A manutenção da vegetação nativa em fragmentos colabora com diversos outros benefícios atribuídos à cobertura vegetal. No Quadro 2, relacionamos os benefícios das manchas da vegetação predominante na área de estudo, assim como a paisagem corredor Rio.

Cabe ressaltar que o tamanho de uma mancha vai depender do contexto paisagístico no qual está inserido, ou seja das atividades que se desenvolvem no entorno do fragmento.

Os corredores de vegetação ao longo dos cursos dos rios, também denominados corredores de recurso ${ }^{11}$ são extremamente importantes na proteção das margens, como fontes de

11 Odum, 2007, pág. 377. 
recursos para as espécies ribeirinhas e aquáticas, no controle da temperatura e incidência de luz nas águas, na manutenção da qualidade e a quantidade de água, entre outras.

\begin{tabular}{|c|c|c|c|}
\hline $\begin{array}{l}\text { Classe de uso e co- } \\
\text { bertura da terra }\end{array}$ & Função Ecológica & $\begin{array}{l}\text { Função socioam- } \\
\text { biental }\end{array}$ & Função cultural \\
\hline $\begin{array}{c}\text { FES - todos os estágios } \\
\text { sucessionais }\end{array}$ & $\begin{array}{l}\text { •Função estabilizadora do } \\
\text { relevo; } \\
\text { •Proteção da qualidade e } \\
\text { da capacidade de reserva- } \\
\text { ção de água; } \\
\text { •Filtragem do ar e efeitos } \\
\text { indiretos na redução de } \\
\text { poluentes; } \\
\text { •Influência na evapo- } \\
\text { transpiração e no balanço } \\
\text { hídrico; } \\
\text { •Efeitos no clima e na } \\
\text { umidade relativa do ar; } \\
\text { •Fonte de alimento; } \\
\text { •Proteção das nascentes e } \\
\text { rios; } \\
\text { •Corredor, habitat e su- } \\
\text { porte para a vida silvestre; } \\
\text { •Obstáculo contra ventos } \\
\text { •Manutenção da biodiver- } \\
\text { sidade; } \\
\text { •Ciclagem de nutrientes; } \\
\text { •Polinização de culturas; } \\
\text { •Controle de pragas; } \\
\text { •Preservação e renovação } \\
\text { da fertilidade do solo; }\end{array}$ & $\begin{array}{l}\text { - Função estabilizadora } \\
\text { do relevo, controle do } \\
\text { risco ambiental, con- } \\
\text { trole de enchentes, ação } \\
\text { restauradora de áreas } \\
\text { degradadas; } \\
\text { - Qualidade e quantidade } \\
\text { de água disponível; } \\
\text { - Efeitos sobre a saúde } \\
\text { - Qualidade do ambiente; } \\
\text { - Efeito estético na paisa- } \\
\text { gem; } \\
\text { - Redução de ruídos } \\
\text { - Sustentabilidade da pai- } \\
\text { sagem } \\
\text { - Segurança alimentar } \\
\text { Recreação }\end{array}$ & $\begin{array}{l}\text { - Patrimônio Paisagístico } \\
\text { - Patrimônio Natural }\end{array}$ \\
\hline Rio & $\begin{array}{l}\text { - Corredor, habitat e fonte } \\
\text { de recursos para diver- } \\
\text { sas espécies; } \\
\text { - Barreira para algumas } \\
\text { espécies }\end{array}$ & $\begin{array}{l}\text { - Lazer e Recreação } \\
\text { - Via de acesso } \\
\text { - Fonte de recursos }\end{array}$ & $\begin{array}{l}\text { - Patrimônio Paisagístico } \\
\text { - Patrimônio Natural }\end{array}$ \\
\hline
\end{tabular}

Quadro 2 - Benefícios ecológicos, socioambientais e culturais da cobertura vegetal. Adaptado de Furlan (2004) e modificado por Giorgia Limnios, 2018.

Outro tema fundamental na discussão da importância dos estudos de ecologia de paisagem diz respeito aos marcos legais. Afinal o território se produz a partir da legislação que embasa as permissões de uso. Neste sentido as áreas protegidas (sensu lato) podem constituir recursos auxiliares a manutenção da estrutura e funcionamento de habitats. Neste sentido a lei florestal de 2012 trouxe o debate sobre a paisagem e as métricas de lei que foram contestadas 
por estudos da ecologia de paisagens (METZGER, 2010).

Os corredores de vegetação ao longo dos cursos dos rios, também denominados corredores de recurso são extremamente importantes, na proteção do perfil das margens, como fontes de nutrientes para as espécies ribeirinhas e aquáticas, no controle da temperatura e incidência de luz nas águas, na manutenção da qualidade e a quantidade de água, entre outras. Por essas funções a manutenção das coberturas vegetacionais nas margens dos devem ser preservadas. Desde 1934 as florestas que acompanham os rios são protegidas. A norma que protege esses vegetais é o código florestal, que desde 1965 definiu um conjunto de métricas de proteção conforme a largura do curso d'água. A nova lei florestal (Lei n ${ }^{\circ} 12.651$, de 25 de maio 2012), que alterou o código florestal de 1965,_manteve as métricas de largura das áreas de preservação permanente dos cursos d' água, porém com uma alteração que gerou grande polêmica. As medidas são tomadas a partir do leito menor do rio e não do leito maior como anteriormente. Isto acarreta em redução substancial da proteção. As larguras das faixas de vegetação são bastantes questionáveis em relação à efetividade de proteção do sistema hídrico, pois não há fundamentação científica para os tamanhos indicados. São as seguintes medidas:

0. 30 (trinta) metros, para os cursos d'água de menos de 10 (dez) metros de largura;

a. 50 (cinquenta) metros, para os cursos d'água que tenham de 10 (dez) a 50 (cinquenta) metros de largura;

b. 100 (cem) metros, para os cursos d'água que tenham de 50 (cinquenta) a 200 (duzentos) metros de largura;

c. 200 (duzentos) metros, para os cursos d'água que tenham de 200 (duzentos) a 600 (seiscentos) metros de largura;

d. 500 (quinhentos) metros, para os cursos d'água que tenham largura superior a 600 (seiscentos) metros;

Ainda no campo das extensões de habitat pesquisadores vem apontando para a necessidade de se pensar qual paisagem está protegida por essas métricas da lei florestal. Apoiado nos estudos de Silva (2003), Silva (2014) esquematizou a relação entre as funções ecossistêmicas e a largura da faixa de vegetação necessária para cumprir funções essenciais a proteção. A Figura 5 apresenta um diagrama esquemático para os diferentes aspectos relacionados ao ambiente fluvial, sem considerar a largura do rio. 


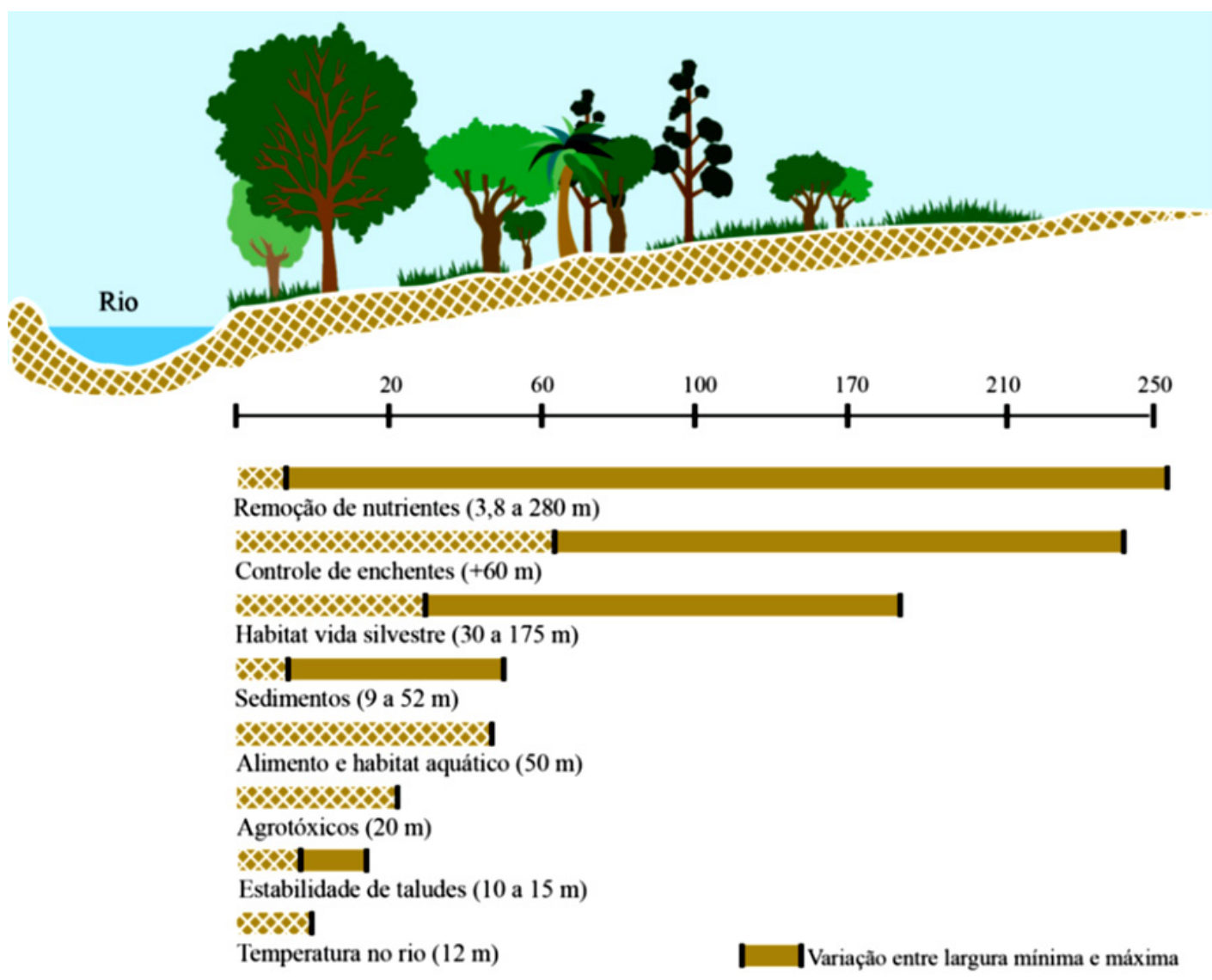

Figura 5 - Extensão da vegetação para o cumprimento das funções das zonas ripárias, segundo revisão realizadas por Silva (2003). Fonte: Silva, 2014.

Esse esquema pode auxiliar na determinação das larguras adequadas da vegetação que possibilitem a proteção das coberturas e dos processos ecológicos desempenhadas pelos corredores. Segundo Odum (2007, pág. 377) a função do corredor depende, entre outros fatores, de sua estrutura, de seu tamanho, de sua forma, de seu tipo e relação geográfica com os arredores.

Os corredores são mais eficientes para a biota quando há conectividade entre as manchas e para algumas espécies essa característica é mais importante que a largura da faixa de vegetação. Porém, a conexão de habitats com longo período de isolamento pode ter efeitos negativos com perturbações que podem causar desequilíbrios locais (VIANA, 1998)

Além das grandes manchas de vegetação, a paisagem contém, ou pode conter, manchas menores na matriz. Em áreas urbanas as manchas ocorrem, muitas vezes, de forma isolada, sem conexão, em uma condição que vários autores definem como "ilha" ambiental (CARBONARI, 1981; VIANA, 1998). Esses fragmentos isolados são habitats importantes para fauna e podem ser utilizados como trampolins (stepping stones) na matriz. Em projetos de paisagem recomenda-se melhorar o fluxo da biota, incrementando a paisagem artificial com manchas e corredores naturais ou artificiais para aumentar a conexão por entre fragmentos. As estruturas verdes urbanas melhoram a qualidade de vida da população, estimulam o uso dos espaços públicos, 
quebram a monotonia visual, possibilitam o lazer e a recreação, controlam a temperatura, entre outros benefícios (PELEGRINO, 2000).

Embora a área do fragmento seja muito importante ecologicamente, pois representa a quantidade de habitat, a configuração espacial do conjunto de fragmentos é ainda mais importante. A conectividade é considerada um "elemento vital da estrutura da paisagem" (TAYLOR et al., 1993), mas sua efetividade tem sido difícil quantificar e implementar na prática. Isso se deve às diferenças entre a continuidade ou "conexão estrutural" dos tipos de manchas (ou habitat) e a conectividade ou "conexão funcional" da paisagem como percebida pelos organismos ou processos ecológicos. A conectividade estrutural refere-se à disposição das manchas na paisagem em que o habitat está fisicamente situado. Se fragmentação, a cobertura vegetal, por exemplo, pode tornar-se desconectada. A noção de conexão e isolamento adota a perspectiva da biogeografia insular, porque o foco está na continuidade de atributos do meio físico de um único tipo de mancha. A conectividade ou “conexão funcional” entre as manchas, depende das funções que o organismo desempenha no nicho ecológico e está relacionada à permeabilidade no padrão de paisagem (MCGARIGAL, 2012).

Do ponto de vista do desenho de conservação houve, inicialmente uma conjectura em torno de três ideias básicas sobre a área e suas ligações numa matriz (Figura 6).

Modelo
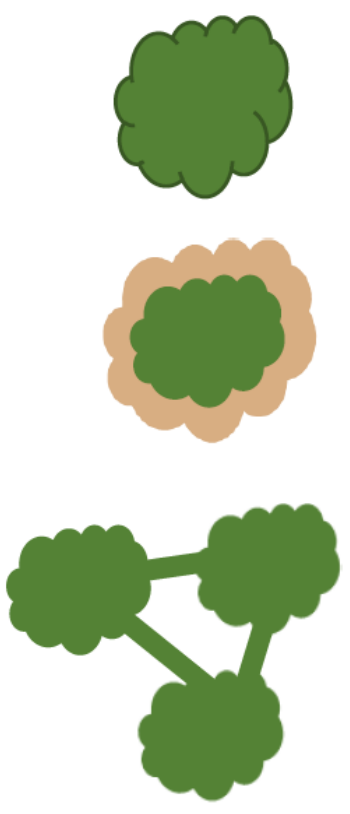

\section{Explicação}

A maior área é que deve ser preservada

A forma protegida com uma buffer - zona de amortecimento ou entorno

A forma deve estar conectada (criando continuidade de habitat)

Figura 6 - Modelo inicial para as manchas na paisagem. Org. Giorgia Limnios, 2018. 
A sustentabilidade dos processos ecológicos existentes nos fragmentos depende basicamente de ações voltadas à conservação e aumento da conectividade dos fragmentos. Devem ser conservadas as áreas com os maiores fragmentos e recuperadas áreas estratégicas de ligação entre manchas para restabelecer ou melhorar as conexões entre os remanescentes, facilitando o fluxo biológico e aumentando as possibilidades da manutenção da biodiversidade na paisagem. (SARTORELLO, 2013)

Esses princípios refletem, em parte, as recomendações e regras geométricas para o estabelecimento de reservas naturais e redes de reservas com princípios em biogeografia de ilhas, propostas Wilson e Willis, apud Brown, 2006 (Quadro 3). As bases conceituais para os desenhos de conservação foram, ao longo do tempo, somando vários conceitos. No Quadro 3 temos um quadro resumo dessas composições conceituais. 


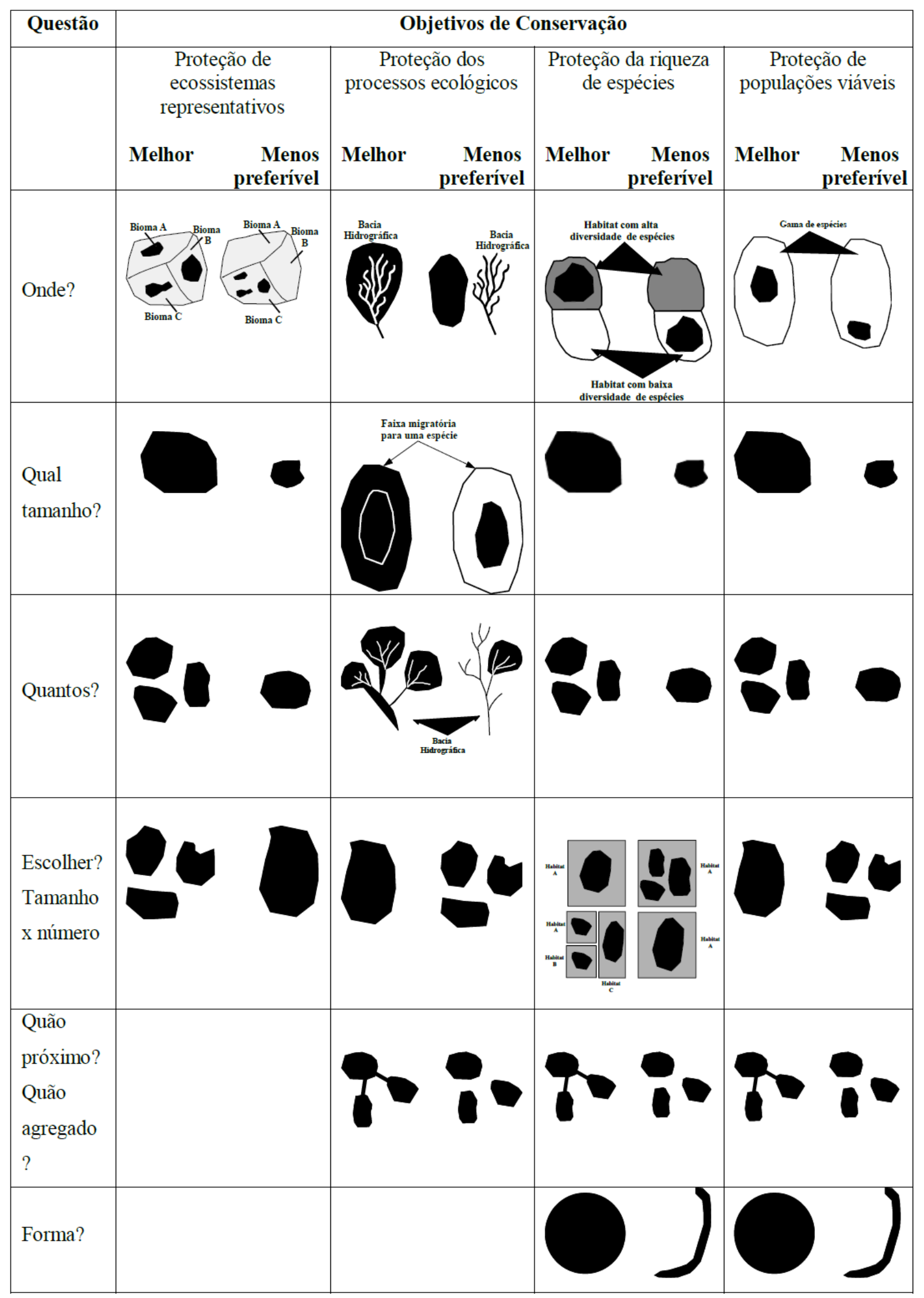

Quadro 3. Guia para seleção e melhor desenho de áreas protegidas em relação aos objetivos de conservação, apresentando exemplos melhores e menos preferíveis. Fonte: Lusigi, 1992. 
O emprego destes critérios é válido quando outros fatores são considerados para melhor desenho da conservação como a representatividade de ecossistemas, endemismo, proteção espécies ameaçadas de extinção, raridade, complementaridade, insubistituibilidade (PRESSEY; MARGULIS, 2000).

O relatório divulgado pela Ecological Society of America (Dale et al. 2000 apud Turner, 2001) destacou as implicações ecológicas do uso da terra quanto aos distúrbios na paisagem. Seis princípios ecológicos do uso da terra foram identificados: tempo, espécies, lugar, produtividade, perturbações e paisagem. Os processos ecológicos ocorrem num cenário temporal, significa que a mudança ao longo do tempo é fundamental para analisar os efeitos do uso da terra na paisagem. Além disso, espécies individuais e redes de interação de espécies têm fortes e amplos efeitos no processo ecológico. Cada local ou região tem um único conjunto de organismos e condições abióticas que influenciam nos processos ecológicos. Distúrbios são importantes eventos ecológicos que podem influenciar fortemente a população comunidade e dinâmicas ecossistêmicas. Finalmente, o tamanho, forma, e relações espaciais dos fragmentos na paisagem influenciam a estrutura e a função dos ecossistemas (TURNER, 2001. pág. 291). Nesta pesquisa esta análise foi o pano de fundo para pensar um possível desenho para a conservação da paisagem elétrica.

\section{Medições ecológicas da paisagem}

O padrão de uma paisagem pode ser melhor conhecido com o auxílio de medições ou métricas ou parâmetros ecológicos que são determinados a partir de mapeamentos de uso e cobertura da terra em diversas escalas espaciais. Pode-se, por exemplo, conhecer o total de classes presentes na paisagem e o quantitativo de cada uma delas, assim como a área que ocupam em determinado território, dando uma ideia da composição paisagística. Outras métricas podem fornecer informações sobre o arranjo espacial das unidades de paisagem. Estas parametrizam o grau de fragmentação, bem como o isolamento e conexão das unidades de uma mesma classe e também a área e forma de cada mancha. Medidas de área e forma correspondem as métricas de disposição.

Existem dois tipos de métricas aplicadas a dados espaciais com objetivos bem distintos: métricas estruturais e métricas funcionais. As métricas estruturais medem a composição física ou a configuração do mosaico de manchas, sem referência explícita a um processo ecológico. Grande parte das métricas da paisagem são deste tipo. As métricas funcionais medem, explicitamente, o padrão da paisagem que é funcionalmente relevante para o organismo ou processo sob consideração. Exigem parametrização adicional antes de seu cálculo, de modo 
que a mesma métrica possa retornar vários valores, dependendo das especificações do usuário. (MCGARIGAL, 2012)

Como visto acima, há duas categorias de métricas que calculam a composição e a configuração nos níveis de mancha, classe e paisagem, que veremos a seguir. As métricas de composição referem-se às características associadas à variedade e abundância dos tipos de manchas dentro do mosaico paisagístico. Não considera a localização das manchas na paisagem, não tem caráter espacial. O conjunto de métricas de composição são aplicáveis principalmente no nível da paisagem. A configuração reflete a espacialidade, a disposição, a posição das manchas dentro da classe ou da paisagem, podendo ser representadas cartograficamente.

Para as duas categorias de métricas, composição e configuração, os cálculos realizados a partir dos mapeamentos de uso da terra podem ser efetuados em três níveis, conforme apresentado por LANG (2009) e McGarigal (2012 p. 77):

1. Nível da mancha: as medidas são aplicadas para as manchas individualmente. Neste nível, as métricas servem como base para cálculos no nível da classe e da paisagem.

2. Nível da classe: as medidas são realizadas para todas as manchas de uma determinada classe pela média simples ou por média ponderada de forma a refletir a contribuição de grandes manchas no índice geral. As medidas desse nível classe analisam a configuração do conjunto de manchas.

3. Nível da paisagem: as medidas referem-se a toda paisagem e assim como as métricas de classe podem ser analisadas por média simples ou ponderada. O foco principal é a compreensão do padrão (composição e configuração) de todo o mosaico paisagístico.

Existem diversas métricas que quantificam a estrutura da paisagem e, muitas delas, são correlatas, pois calculam uma mesma informação de formas diferentes. Assim, é importante definir aquelas mais adequadas para os objetivos pretendidos, tarefa que exige conhecimento para alcançar os resultados que reflitam o arranjo espacial da paisagem. Para Turner (2001, p. 132), "uma métrica é insuficiente para caracterizar uma paisagem, mas não há uma receita padrão para determinar quantas e quais métricas são necessárias". Com base na facilidade de cálculo e interpretação, a autora sugere pelo menos cinco métricas que são relativamente independentes umas das outras. 


\section{Efeito de borda e fragmentação}

A fragmentação de paisagens gera efeitos sobre os habitats. Esses efeitos de contato entre um fragmento e seu entorno é chamado efeito de borda. O contato de ambientes distintos, como por exemplo, um fragmento florestal com outro não florestal, apresenta alterações dos fatores abióticos como a luminosidade, umidade do ar e do solo, temperatura e modificações na composição da biota. Essas áreas de transição apresentam características que variam de acordo com o tamanho e estrutura do fragmento, sua localização e orientação na paisagem.

A radiação solar nas bordas é mais intensa nas margens e gradativamente se reduz em direção ao interior, se estabilizando a partir de 20 metros de distância. A intensidade dos ventos altera a condição de umidade na faixa de borda, sendo mais seco nas margens e mais úmido para o interior, com alcance em torno de 60 metros adentro da floresta. A temperatura do ar também é alterada, sendo maior no limite de contato, atingindo equilíbrio a partir de 24 metros de distância. Essas características microclimáticas possibilitam a ocorrência de espécies mais adaptadas à essas condições, conhecidas como generalistas, que competem por espaços e recursos com as espécies anteriormente presentes, influenciando no aumento da diversidade da fauna e flora na borda (MURCIA, 1995; RODRIGUES, 1998; METZGER, 1998).

Os efeitos de borda são mais acentuados no limite dos contatos e diminuem para o interior do fragmento e para cada aspecto biótico e abiótico existe tamanhos diferenciados de bordas e estas irão variar conforme as características locais

A análise da paisagem a partir do estudo da configuração territorial permite avaliar os potenciais ecológicos (estruturais e funcionais) dos fragmentos que auxiliam no ordenamento territorial e na proteção paisagística. 


\section{Patrimônio}

O patrimônio ${ }^{1}$ carrega, historicamente o sentido e a ideia de monumento, seja por um objeto edificado com a função de remeter à memória de um tempo, de um estilo de vida, de uma técnica ou por representar a ideia de recordação de um tempo em seu sentido original. Pode ainda ser representado por uma obra do passado ressignificada em outro momento em função da leitura histórica (CHOAY, 2000). Na primeira perspectiva, a autora aponta que o passado manifestado no objeto edificado, não é um passado qualquer, foi localizado e selecionado para fins vitais, na medida em que pode, diretamente, contribuir para manter e preservar a identidade de uma comunidade, étnica ou religiosa, nacional, tribal ou familiar (CHOAY op.cit).

Tanto para os que edificam, como para aqueles que recebem as advertências, o monumento é uma defesa contra o traumatismo da existência, um dispositivo de segurança. O monumento assegura, sossega, tranquiliza, ao conjurar o ser do tempo. É garantia das origens e acalma a inquietude que gera a incerteza dos princípios. Desafio à entropia, à ação insolvente que o tempo exerce sobre todas as coisas, naturais e artificiais, o monumento procura apaziguar a angústia da morte e da aniquilação" (CHOAY, 2000, p.16 )

O monumento histórico pode estar associado à edificação, isolada ou em conjunto, sendo um testemunho do passado reconhecido a partir de recortes cronológicos, geográficos, estilísticos e tipológicos bem definidos pelos sujeitos que o valorizam. Portanto a valorização é uma perspectiva coletiva. As edificações tornam-se históricas, em momentos posteriores à sua construção, muitas vezes em situações em que a possibilidade de destruição ou desaparecimento são iminentes, quando está em risco por novas camadas de interpretação do seu valor como monumento. O reconhecimento já existe, mas a ação de proteger nasce em momentos em que a memória associada ao momento corre risco de ser apagada.

Em algumas situações, os movimentos sociais se organizam pela permanência de um bem que possui valor numa rede de significados de um coletivo. Um exemplo de ação pela proteção de conjunto edificado foi movido por moradores do bairro de Pinheiros, na cidade de São Paulo, no início dos anos 2000. A área envolvida pela Rua Mourato Coelho, Rua Arthur de Azevedo, Rua Teodoro Sampaio e Avenida Pedroso de Morais foi uma hípica entre as décadas de 1920 e 1950 e, pela impossibilidade de expansão desse uso, foi transferida para

1 A palavra patrimônio relacionava-se, originalmente, às estruturas familiares, econômicas e jurídicas de uma sociedade estável, enraizada no espaço e no tempo (CHOAY, 2000, pág. 11). A acepção do termo trata dos bens transmitidos hereditariamente e, a esse conceito, foram acrescidos adjetivos que atribuem novos significados para as heranças que marcam um tempo, um lugar, um saber fazer, um fato social. Cultural, ambiental, artístico, arqueológico, histórico, paisagístico, são algumas qualificações que designam os patrimônios mais representativos de uma sociedade, adotados conforme novos entendimentos e necessidades que surgiram para serem mais representativos às suas finalidades 
Santo $\mathrm{Amaro}^{2}$, dando lugar à construção de 56 edifícios de 3 pisos e 39 sobrados $^{3}$ ainda na década 1950. O conjunto prédios possui mesmo gabarito, com três andares, porém apresentam algumas características singulares em cada condomínio, como por exemplo, diferentes estilos de varandas e fachadas. A maioria das edificações apresenta pequenos jardins frontais e áreas para estacionamento de veículos. As vias secundárias são pavimentadas com paralelepípedos e arborizadas com espécies frutíferas. Faz parte do conjunto o edifício da Escola Estadual Fernão Dias Paes. No início dos anos 2000 dois edifícios localizados na Rua Simão Álvares foram demolidos para a construção de outro edifício em estilo neoclássico, com 17 andares. A partir deste fato moradores se organizaram num movimento para solicitar ao Conselho Municipal de Preservação do Patrimônio Histórico, Cultural e Ambiental da Cidade de São Paulo (Conpresp) o tombamento da área a fim de preservar as formas, arruamentos, pavimentação, arborização e recuos do conjunto urbanístico do que restava à época. Atualmente, a área deste residencial está classificada como Zona de Preservação Cultural ${ }^{4}$ (ZEPEC), pela Lei 16.402 de 22/03/2018, inseridas nas categorias Bens Imóveis Representativos ${ }^{5}$ (BIR), que compreende a escola, e Áreas de Urbanização Especial ${ }^{6}$ (AUE), que abrange o restante da área. O processo tramita no órgão do patrimônio municipal com decisão favorável a preservação. Nesse caso, a prefeitura de São Paulo reconheceu o valor histórico, urbanístico, paisagístico, simbólico e afetivo relacionados a esse conjunto, decidindo favoravelmente ao tombamento com existência de área envoltória, conforme solicitado pelos moradores. Uma vitória do movimento social local pela preservação, que em muitos outros casos não foi exitosa, como por exemplo a demolição criminosa do conjunto de mansões dos Barões do café da Av. Paulista e o Parque do Povo ${ }^{7}$ que teve seu uso modificado.

2 Nesta época Santo Amaro era outro município até 1935

3 Cássia C. Nobre. Conjunto residencial "Predinhos da Hípica". http://www.vitruvius.com.br/revistas/read/arquitextos/07.080/279. Acessado em 16/03/2018.

4 Lei 16.402 de 22/03/2018, que disciplina o parcelamento, o uso e a ocupação do solo no Município de São Paulo, de acordo com a Lei $n^{\circ} 16.050$, de 31 de julho de 2014 - Plano Diretor Estratégico (PDE).

5 As Zepecs-BIR (Bens Imóveis Representativos) são bens de valor arquitetônico ou histórico. Dentro dessa categoria estão igrejas, edifícios históricos e casas bandeiristas, entre outros. A Zepec-BIR oferece ao proprietário a possibilidade de obter recursos, vinculados à conservação do imóvel, por meio da TDC (Transferência do Direito de Construir). Ou seja, o potencial construtivo de sua propriedade (que equivale a uma vez a área do terreno para imóveis de até $500 \mathrm{~m}^{2}$ ) pode ser vendido para construtoras usarem em terreno apto a ser verticalizado.

6 As Zepecs-AUE (Áreas de Urbanização Especial) englobam conjuntos urbanos históricos de características singulares do ponto de vista da morfologia urbana, arquitetônica, paisagística ou do ponto de vista cultural e simbólico. Hoje em São Paulo, temos como exemplo os Bairros Jardim e outras ocupações históricas na cidade que podem vir a se enquadrar nessa categoria de Zepec e que já estão em processo de tombamento: Centro Histórico da Penha e Núcleo de São Miguel Paulista.

7 Resolução de Tombamento SC24/1995 de 03/06/1995. 


\section{Predinhos da Hípica - Bairro de Pinheiros - São Paulo/SP}

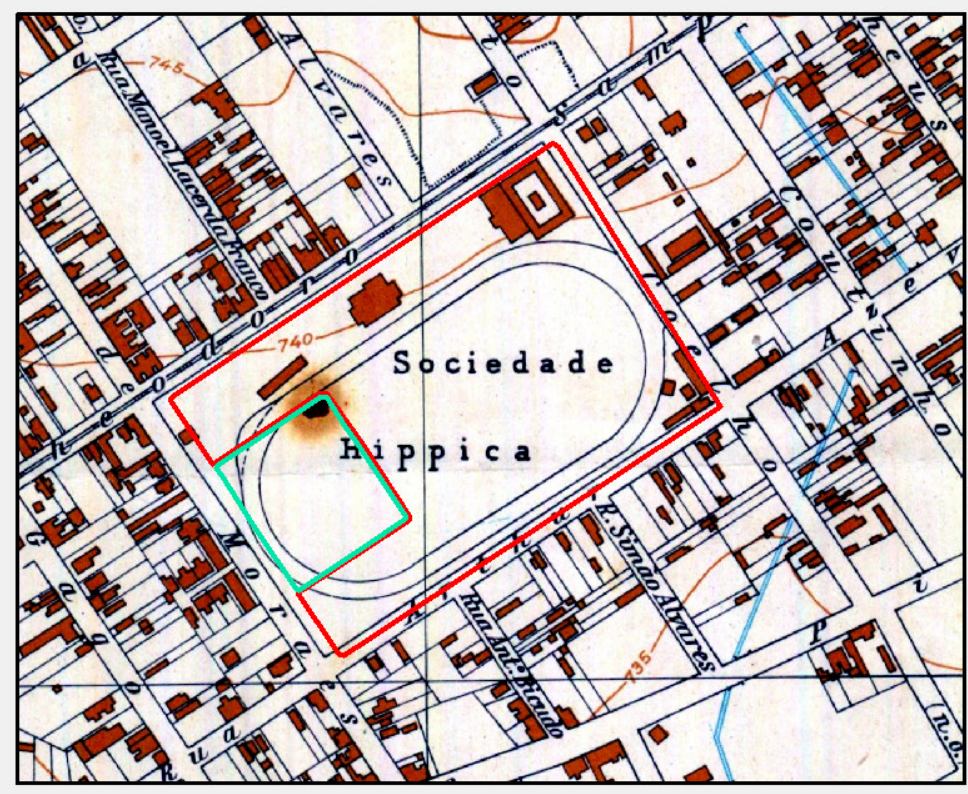

Figura 7 - Carta SARA BRASIL 1930. Escala da imagem: 1:7.000

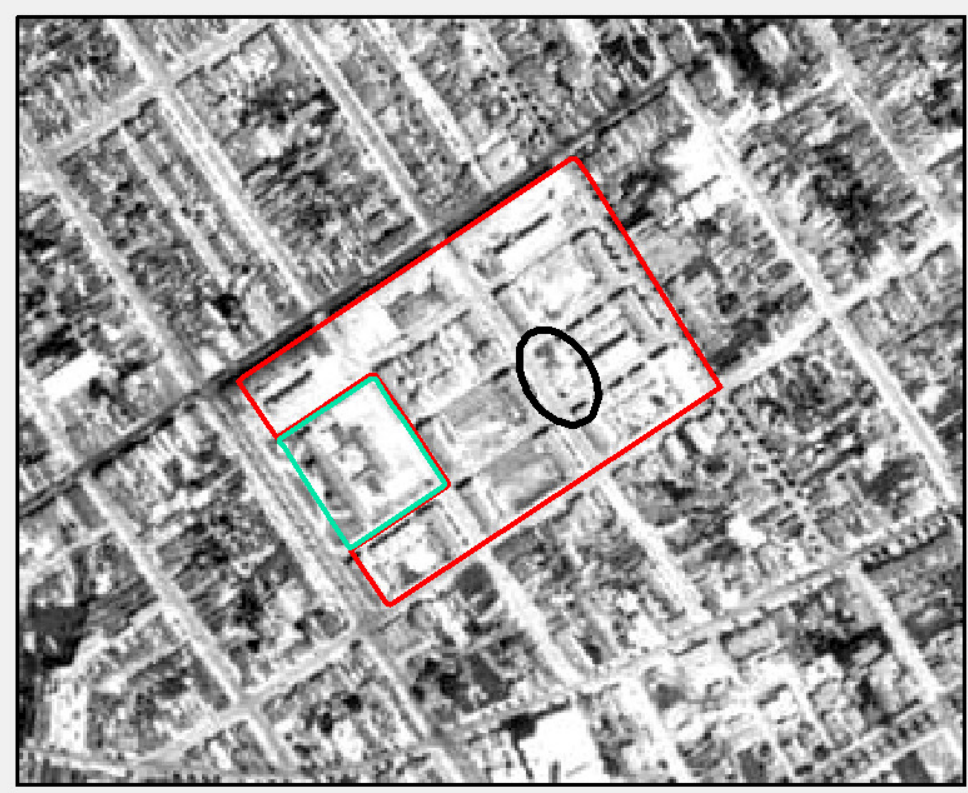

Figura 9 - Foto aérea 1954 (VASP). Escala da imagem: 1:8.000

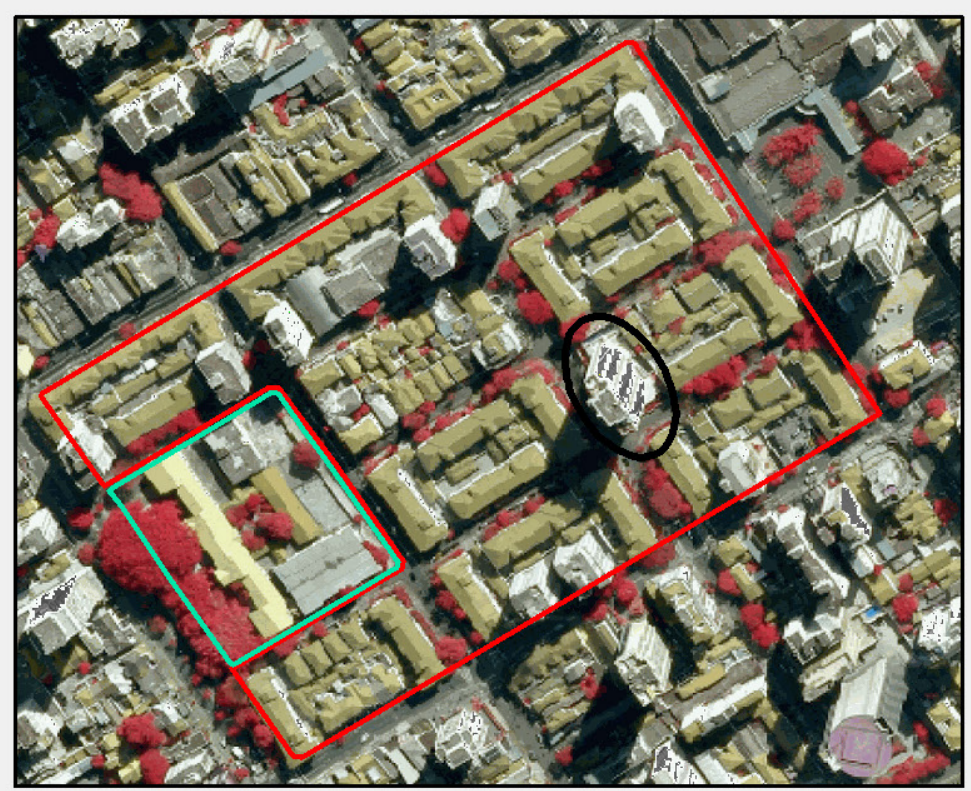

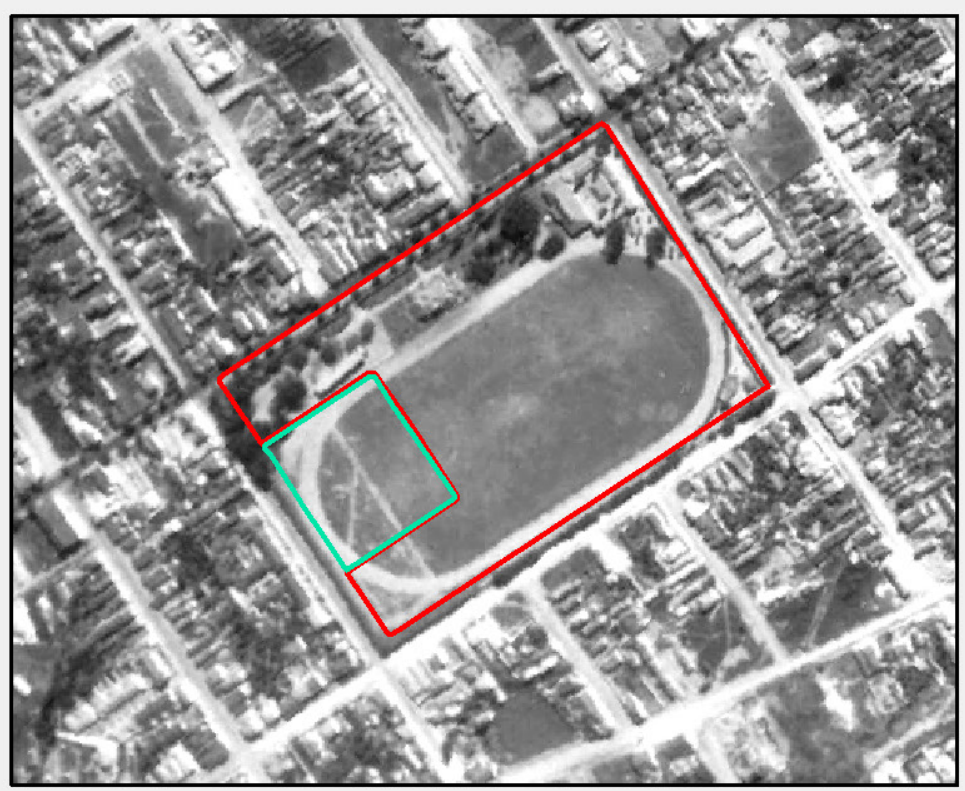

Figura 8 - Foto aérea 1940 (DNPM). Escala da imagem: 1:7.000

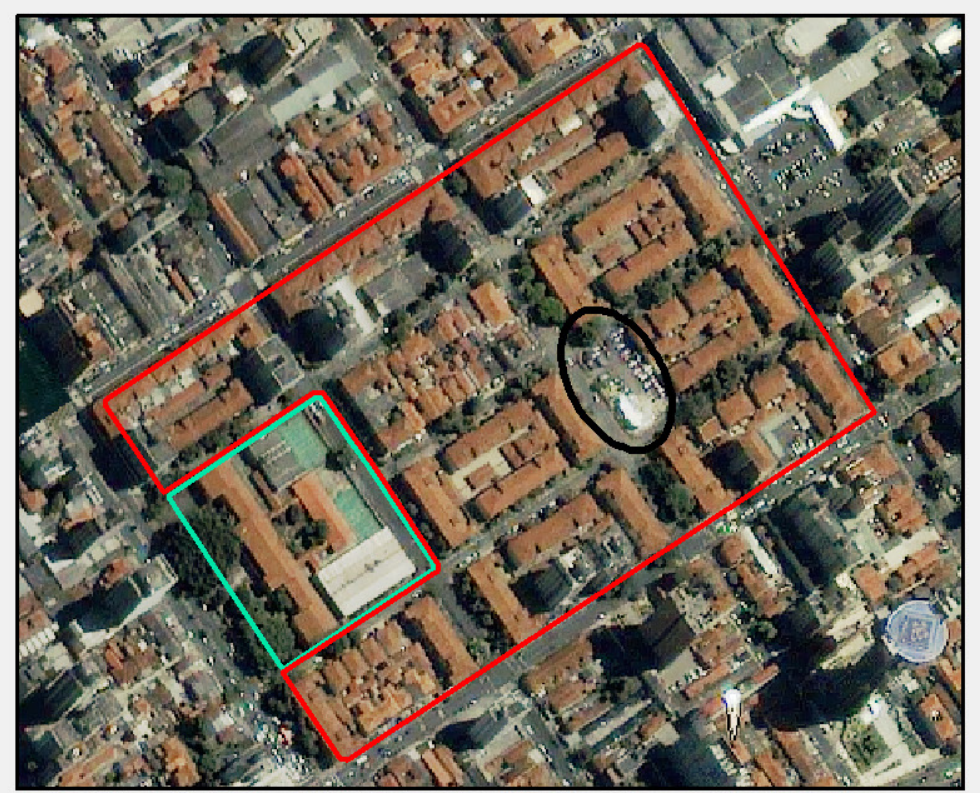

Figura 10 - Imagem de satélite 2002 (IKONOS).

Escala da imagem: 1:5.000

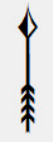

\section{Legenda}

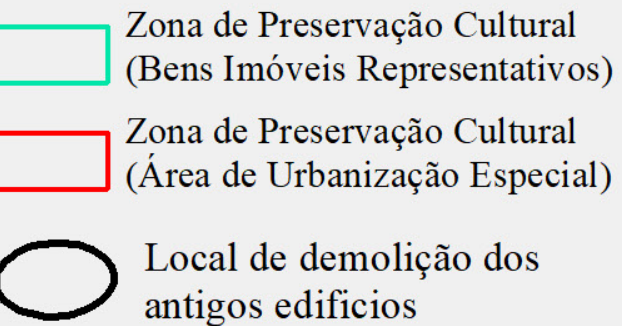


Retomando a trajetividade do conceito de monumento com o passar do tempo, outros significados foram atribuídos ao termo. A ele foi conferido valor arqueológico, valor estético, valor arquitetônico, valor artístico, valor natural, valor ambiental, geológico segundo os interesses em evidenciar determinado fato cultural e ampliando o sentido atribuído ao termo.

Muitos objetos foram sendo associados ao monumento, por exemplo os jardins, principalmente os chamados jardins históricos, facilmente assimilados às demais categorias do patrimônio histórico (Gouty, 1993 apud Meneses, 2002, pág. 51).

Ao recordar a expressão “estranho objeto-tempo" de Daniel Sibony, Dubost (1998 p.) "indaga a relação entre o patrimônio vegetal e a ideia de monumento, pois as plantas como seres vivos, perecíveis, efêmeros e reproduzíveis não fixam a imagem do passado". No entanto as plantas e os jardins formados pelos arranjos estéticos dos elementos vegetais são estruturantes de diversos espaços, que despertam lembranças e alimentam sonhos e o imaginário das pessoas.

Essa efemeridade da vegetação é relativa, pois sua permanência pode ser tanto ou mais duradoura que alguns monumentos construídos, por exemplo, o bosque de jequitibás do Parque Estadual de Vassununga (município de Santa Rita do Passa Quatro-SP) que possuem idade estimada de 500 anos, porém existe um exemplar com 3.020 anos, sendo considerada a árvore mais antiga do Brasil.

A noção de patrimônio vegetal associada aos jardins históricos surgiu na França, concomitante com a ideia de patrimônio natural, no início dos anos 1960. As pessoas amadoras, na conceituação de Dubost (op.cit) tiveram um papel pioneiro no processo de patrimonialização desses locais, pois foram elas que se mobilizaram pela salvaguarda de espécies vegetais em vias de desaparecimento, bem como a proteção e restauração dos jardins históricos, ao resgatar plantas antigas e nativas, além de promoverem a redescoberta da arte dos jardins. No Brasil os primeiros tombamentos de jardins históricos foram efetivados no final dos anos 1930, e mais recentemente, em 2015, o tombamento dos jardins de Roberto Burle Marx na cidade de Recife/ PE foi homologado pelo IPHAN. Em São Paulo um jardim do mesmo botânico foi tombado na antiga Chácara Tangará (Parque Burle Marx) e o Jardim da Luz, antigo Horto Botânico inaugurado em 1798 também recebeu proteção cultural, sendo tombado pelo Condephaat em 1981. A grande relevância cultural desses dois jardins paulistanos resultou na proteção nos níveis municipal e estadual. 


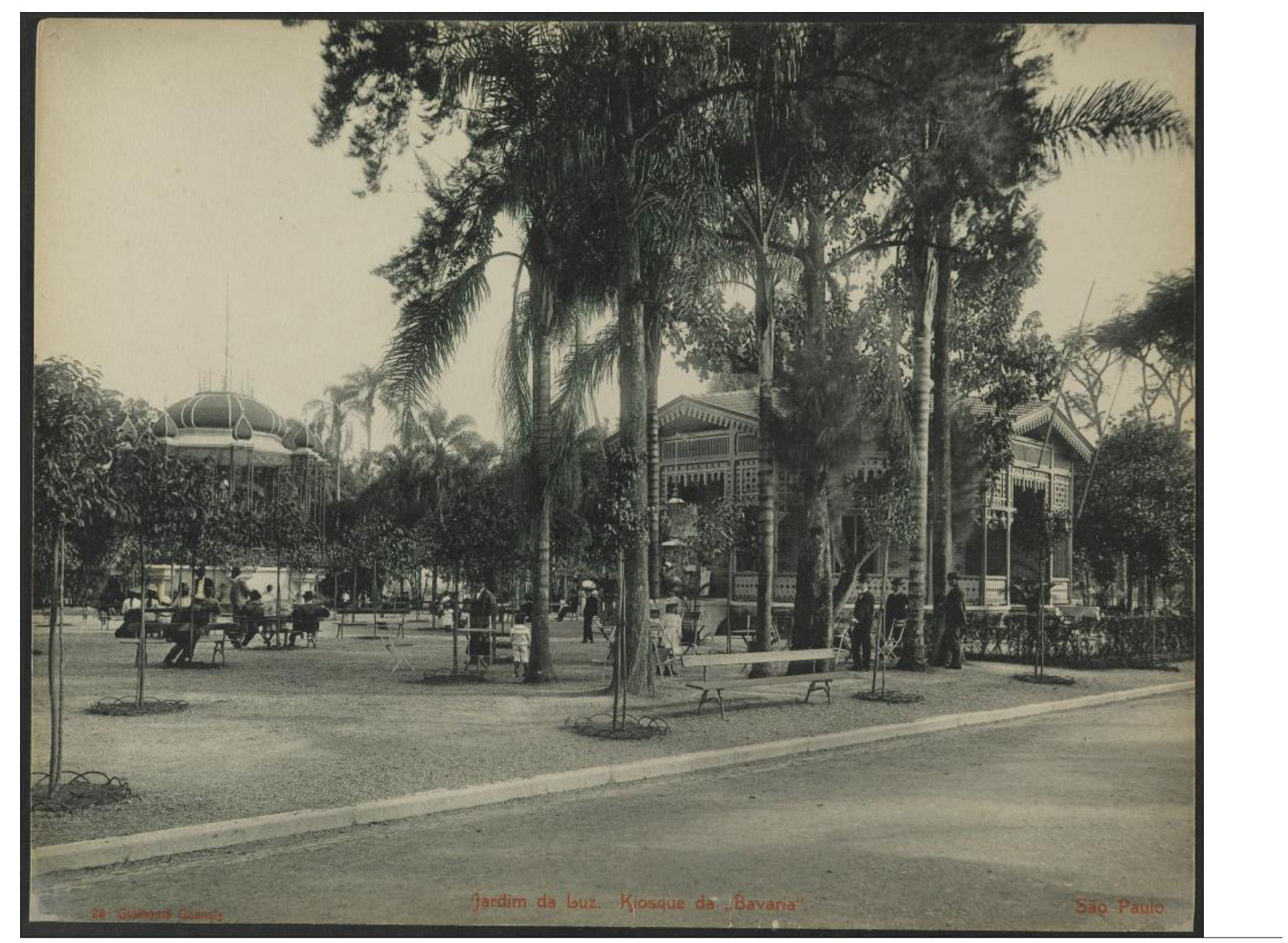

Figura 13 - Desde 1798 o Jardim da Luz, antigo Horto Botânico, é uma importante área de lazer de São Paulo. Fotografia: Guilherme Gaensly, 1902? Fonte: Biblioteca Nacional ${ }^{8}$.

Assimilando a ideia de jardim histórico como monumento, estabelecida na Carta de Florença de 1981, a Carta de Juiz de Fora ${ }^{9}$ define essa categoria como sítios e paisagens trabalhadas pelo humano, nos quais o elemento principal é a cobertura vegetal presente nos jardins botânicos, praças, parques, lagos, passeios públicos, alamedas, hortos, pomares, quintais, jardins privados e jardins de tradição familiar, zoológicos, claustros, hortas, cultivos rurais, cemitérios, vias arborizadas de centros históricos, espaços verdes circundantes de monumentos ou de centros históricos urbanos, áreas livres e espaços abertos, entre outros.

Valorizações da cobertura vegetal vem sendo indicada para proteção por seu valor paisagístico, estético e ecológico. Toda vegetação arbórea do município de São Paulo é considerada bem de interesse comum e alguns conjuntos arbóreos e exemplares isolados, identificados na publicação 10 "Vegetação Significativa do Município de São Paulo" de 1988, foram declarados

8 http://objdigital.bn.br/objdigital2/acervo_digital/div_iconografia/icon325123_1045448/icon1045427.jpg

9 Carta dos Jardins Históricos Brasileiros de 2010.

10 A publicação identifica e mapeia a vegetação e a flora presente nos seguintes locais: parques e reservas, praças e espaços urbanos, áreas institucionais e de uso público, cemitérios, clubes e áreas de recreação, escolas, logradouros públicos de bairros-jardins, bairros e logradouros arborizados, lotes de uso residencial, lotes industriais, agrupa- 
patrimônio ambiental, mediante o Decreto Estadual no. 30.443 de 1989. Este decreto foi fundamentado a partir dos princípios de proteção ambiental e não utiliza o instrumento de tombamento para a proteção, mas foi reconhecida nas palavras de Jorge Wilheim $(1988)^{11}$, que a

\begin{abstract}
vegetação presente na cidade de São Paulo, em suas ruas, seus parques, seus jardins refletem de algum modo a imagem da evolução da cidade: a ocorrência e o adensamento de determinadas espécies botânicas se explicam pelas particularidades culturais dos habitantes, por seus usos e costumes e, principalmente, pela maneira de pensar e agir diante da natureza.
\end{abstract}

Foi reconhecida a qualidade cultural da cobertura vegetal arbórea existente no município, mas o manejo e proteção são realizados somente pelo órgão vinculado ao meio ambiente. Essa determinação estadual também poderia ser apropriada pelo órgão cultural para o reconhecimento dos valores culturais associados à vegetação e flora, como uma normativa a mais dentro do escopo de proteção.

A visão monumental gerou uma série de desencadeamentos de proteção como vimos acima. Outro aspecto que podemos destacar é que o monumento também está associado a aspectos de grandiosidade, poder e beleza (CHOAY, 2000) sendo um superlativo atribuído a algumas construções e também aos atributos naturais da paisagem ou mesmo fragmentos de paisagens.

Uma das manifestações de poder praticadas por pessoas ou instituições, há centenas de anos até os dias atuais, está na magnitude de algumas edificações, pois obras imponentes se destacam na paisagem; podem ser vistas de vários pontos de vista e a partir delas pode-se ter uma visão abrangente; tornam-se referências espaciais; mudam os esquemas urbanísticos; concentram pessoas e atividades; apequenam as pessoas e qualquer outra coisa que esteja em seu entorno; ornamentos exclusivos e raros presentes nas construções determinam estilos e também lhe conferem o status.

A paisagem predominantemente natural, com feições excepcionais, notáveis pela raridade dos sítios ou que possuem grande valor cênico também são designadas como monumento. O Sistema Nacional de Unidades de Conservação da Natureza (SNUC), dispositivo federal, criado em 2000, estabelece critérios e normas para a criação, implantação e gestão das unidades de conservação, e especifica a categoria Monumento Natural como um tipo de unidade de proteção integral e prevê, dentre os objetivos gerais da lei, a proteção das características relevantes de natureza geológica, geomorfológica, espeleológica, arqueológica, paleontológica e cultural. No Estado de São Paulo, em 2014, foi criado o Sistema de Informação e Gestão de Áreas Pro- 
tegidas e de Interesse Ambiental do Estado de São Paulo - SIGAP ${ }^{12}$ que incluiu no Sistema Ambiental Paulista categorias da proteção patrimonial como Área Natural Tombada, Áreas do Patrimônio Mundial Natural, Monumento Geológico e Paisagem Cultural.

Durante muito tempo, porém, a paisagem que ingressa no rol do patrimônio cultural - reconhecida como um bem de interesse coletivo pelo poder público e merecedora de sua proteção - foi tratada como monumento". (Meneses, 2002 p. 50)

Na primeira carta patrimonial elaborada em Atenas (Grécia), em 1931, o monumento está associado às edificações isoladas ou em conjunto, localizadas em áreas urbanas ou rurais, que apresentam significado histórico ou artístico. Esses valores foram reconhecidos a partir da compilação das legislações dos países europeus sobre o tema, e foram mantidos neste documento e em outras recomendações publicadas posteriormente. Na Carta de Veneza, de 1964, permanece a noção de monumento histórico como criação arquitetônica isolada, bem como o "sítio urbano ou rural que testemunhe uma civilização particular, uma evolução significativa ou um acontecimento histórico". Esta noção estende-se não só às grandes criações, mas também às obras "modestas que adquirem com o tempo um significado cultural", por exemplo, a cabana ${ }^{13}$ localizada nas margens do Rio Pardo (São José do Rio Pardo-SP) onde o escritor Euclides da Cunha escreveu a obra "Os Sertões".

Quando os monumentos são eleitos isoladamente, dentro de um contexto no qual haja elementos que fazem sentido para sua existência, negam-se os vínculos socioculturais, espaciais, históricos e ambientais essenciais da sua permanência. Pois um bem está inserido numa rede de significados e possui vínculos afetivos com as pessoas. Separá-lo, descontextualizá-lo cria uma ruptura de entendimento.

Meneses (2002 p.) adverte que a

monumentalização toma elementos da paisagem e os transforma em fetiches, por assim dizer sacralizados, dotados de valores próprios, como se fossem autônomos, imutáveis, independentes das contingências da vida sociocultural, independentes também, do próprio contexto ambiental. O monumento é sempre algo que seu entorno não é. Ao sobressair, o monumento assume, sozinho, os significados dispersos no espaço de que faz parte. $\mathrm{O}$ autor ainda assinala uma mudança relevante ocorrida no final de década de 1960 quando o termo "bem cultural" passa a substituir a categoria monumento no campo patrimonial, conferindo novo significado aos bens; de condição isolada ou simplesmente justaposta para uma integração espacial mais consistente.

Segundo Scifoni (2006_a superação de uma visão monumental que separa o sentido

12 O SIGAP foi instituído por meio do Decreto Estadual no 60.302 de 27 de março de 2014.

13 A cabana foi um dos primeiros bens culturais tombados pelo IPHAN em 1938. 
e vínculo com o contexto social dos objetos de valor cultural re-aproxima os diversos grupos sociais do sentido do patrimônio, pois reconhece-se a "importância naquilo que é a expressão típica de suas culturas, entendidas como o produto de uma relação que é estabelecida com a natureza. Assim sendo, superou-se também uma visão de patrimônio centrada no edificado para valorizar outros objetos, entre eles os derivados da natureza, processo que se deu como fruto de uma conquista social na medida em que a sociedade, sob a forma de grupos organizados, colocou na agenda política esta nova demanda" (Scifoni, 2006, p. 6).

Os valores históricos e artísticos atribuídos às construções europeias merecedoras de atenção foram adotados nas primeiras jurisprudências brasileira sobre a proteção do patrimônio, bem como algumas orientações de valorização. A primeira menção referente ao patrimônio brasileiro ocorre na Constituição de 1934, a qual estabelecia a proteção "dos objetos de interesse histórico e o patrimônio artístico do País" pela União, Estados e Municípios, conforme texto constante no artigo 148. Posteriormente, foi publicado o Decreto-Lei n ${ }^{\circ} 25$, de 30 de novembro de 1937, como a primeira legislação que organiza a proteção do patrimônio histórico e artístico nacional, e que ainda vigora. Mas, a redação apresentada pelo governo Vargas não corresponde totalmente ao anteprojeto elaborado por Mário de Andrade, a pedido de Gustavo Capanema, então Ministro da Educação e Saúde no período de 1934 - 1945 qual seria a base da nova jurisprudência.

As propostas apresentadas no anteprojeto de 1936 seriam as bases da nova legislação nacional e Mário de Andrade "tentava preservar a totalidade dos bens culturais brasileiros o que incluía hábitos, crendices, cantos, lendas e superstições populares" e valorizar a diversidade cultural do Brasil (SALA, 1990, pág. 21). O autor ainda acrescenta que a adoção parcial das propostas de Mario de Andrade estava associada ao equilíbrio dado entre "o popular e o erudito" e ao enfoque expressivo "nos aspectos imateriais da cultura", óticas essas que não se alinhavam com as ideias do governo à época. Pode-se verificar, por exemplo, que o termo "popular" presente no entendimento sobre o patrimônio artístico nacional no anteprojeto (Quadro 4), foi excluído do artigo $1^{\circ}$ e do capítulo I do Decreto-Lei, e outros termos como "povo" e "cultura", sequer são citados.

\begin{tabular}{|l|l|}
\hline \multicolumn{1}{|c|}{ Projeto de Mário de Andrade (1936) } & \multicolumn{1}{c|}{ Decreto-Lei no 25/1937 } \\
\hline $\begin{array}{l}\text { Definição do Patrimônio Artístico Nacional: } \\
\text { Entende-se por Patrimônio Artístico Nacional }\end{array}$ & $\begin{array}{l}\text { Art. } 1^{\circ} \text { Constitue o patrimônio histórico e artís- } \\
\text { tico nacional o conjunto dos bens móveis e imó- } \\
\text { todas as obras de arte pura ou de arte aplica- } \\
\text { da, popular ou erudita, nacional ou estrangeira, } \\
\text { pertencentes aos poderes públicos, a organis- } \\
\text { mos sociais e a particulares nacionais, a parti- } \\
\text { culares estrangeiros, residentes no país e cuja conservação seja } \\
\text { de interêsse público, quer por sua vinculação } \\
\text { a fatos memoráveis da história do Brasil, quer } \\
\text { por seu excepcional valor arqueológico ou } \\
\text { etnográfico, bibliográfico ou artístico }\end{array}$ \\
\hline
\end{tabular}


Quadro 4: Perspectivas sobre patrimônio. Fonte: SALA, 1990

O decreto-Lei não é fiel ao anteprojeto de Mário. Não escapou aos teóricos e articuladores do Estado Novo o perigo representado pela iniciativa paulista em seu sentido de democratização da cultura, principalmente uma cultura imaterial representativa de etnias que tinham no Brasil o seu lugar geográfico e que atrapalhavam das mais diversas formas seu projeto nacionalista. Basta ver que nada foi feito em função do índio ou do negro, ou mesmo da cultura ligada ao sindicalismo anarquista dos operários italianos em São Paulo até que essas questões fossem recentemente recolocadas. Como também não escapou a esses mesmos teóricos, conhecedores que eram das técnicas fascistas de propaganda, a função do bem cultural material, no duplo sentido de cooptar elites dominantes proprietárias ou de passado ligado a esses bens e de utilizar a função teatral da monumentalidade arquitetônica transformada em símbolo da pátria (SALA, 1990. p. 25)

Nos primeiros anos de atuação do Serviço do Patrimônio Histórico e Artístico Nacional (SPHAN) ${ }^{14}$, atual instituto do Patrimônio Histórico e Artístico Nacional (IPHAN), foram declarados, até o final de década de 1930, 333 patrimônios nacionais, sendo que metade deste total se refere à edificações e acervos de religiosos, tais como capelas, conventos, mosteiros e igrejas construídos, em grande parte, no período colonial, e localizados, principalmente, nas cidades do Rio de Janeiro e Salvador. Nota-se também, na lista ${ }^{15}$ dos bens tombados, que imóveis relacionados a palácios, casas de personagens ilustres ou construídas por arquitetos renomados também foram selecionados para a proteção legal. Essa tendência continuou nos anos seguintes e indica a inclinação em proteger determinados modelos arquitetônicos, períodos históricos e estilos artísticos representativos de uma classe social dominante e influentes nas decisões do tombamento.

O conjunto eleito revela o desejo por um país do passado, com quatro séculos de história, extremamente católico, guardado por canhões, patriarcal, latifundiário, ordenado por intendências e casas de câmara e cadeia, e habitado por personagens ilustres, que caminham entre pontes e chafarizes" (RUBINO, 1996. p. 98).

Podemos de alguma maneira relacionar essa abordagem a especialização também das equipes técnicas na instituições de proteção patrimonial. O Iphan e também o Condephaat (Estado de São Paulo) raramente contaram com a contribuição de geógrafos no seu quadro profis-

14 O SPHAN foi instituído no Decreto-Lei n ${ }^{\circ} 25$ como o órgão federal responsável pela preservação, classificação, registro e pesquisa do patrimônio histórico e artístico nacional.

$15 \mathrm{http} / / /$ portal.iphan.gov.br/uploads/ckfinder/arquivos/Lista_bens_tombados_processos_andamento_2018.

Acesso em 13/03/2018 
sional. Mesmo historiadores e arqueológos estão menos representados.

No Brasil a aplicação do instrumento de tombamento às paisagens nem sempre encontrou eco dentro das instituições de patrimônio. No Iphan constam 24 bens protegidos que se enquadram na categoria de paisagem natural - representando pouco menos de $2 \%$ do total de bens tombados - e praticamente metade deles corresponde a formações naturais do Rio de Janeiro (Pão de Açúcar, Corcovado, Pedra da Gávea, Floresta da Tijuca). No Condephaat a polêmica sobre a gestão das paisagens se arrasta a anos, desde o tombamento da Serra do Mar em 1985.

Reconhecendo que muito há que se avançar nesta temática, em 2009, foi criada a Coordenação-Geral de Patrimônio Natural, Paisagem Cultural e Jardins Históricos, propiciando uma estrutura técnica mínima para se traçar uma nova estratégia de atuação nesta temática" (IPHAN, 2011).

Cabe destacar que, no Brasil, a paisagem é o conceito central na definição das Áreas Naturais Tombadas e a proteção patrimonial é uma dimensão geográfica utilizada apenas pelos órgãos de patrimônio. Daí a grande responsabilidade política e técnica destas instituições. Uma outra questão fundamental é a seleção de paisagens que podem e devem ser protegidas. Concordamos com Canclini quando afirma que

Atualmente, as diferenças regionais, originadas pela heterogeneidade de experiências e pela divisão técnica e social do trabalho, são utilizadas pelos setores hegemônicos para que obtenham uma apropriação privilegiada do patrimônio comum. Consagram-se como superiores certos bairros, objetos e saberes, porque estes foram gerados pelos grupos dominantes, ou porque tais grupos contam com a informação e formação necessárias para compreendê-los e apreciá-los, ou seja, para controlá-los melhor. O patrimônio cultural serve, assim, como recurso para produzir as diferenças entre os grupos sociais e a hegemonia dos que gozam de um acesso preferencial à produção e distribuição de bens" (Canclini, 1994, p.97).

É importante ainda destacar que um testemunho do passado, o patrimônio é um retrato do presente como registro "das possibilidades políticas dos diversos grupos sociais, expressas na apropriação de parte da herança cultural, dos bens que materializam e documentam sua presença no fazer histórico da sociedade. O patrimônio não é, porém, uma representação de "todos"; este modo de concebê-lo resultou de um momento histórico no qual os bens protegidos pelo Estado representavam a afirmação da identidade nacional” (RODRIGUES, 1996, p. 195). 


\section{O tombamento}

O instrumento de tombamento foi o primeiro dispositivo de proteção do patrimônio brasileiro, sendo instituído no Decreto-Lei 25 de 1937, como forma de proteção integral dos bens declarados pelo então Serviço do Patrimônio Histórico e Arqueológico Nacional - SPHAN. É o instrumento de proteção mais conhecido e adotado nas práticas de preservação em todas as esferas institucionais governamentais. $\mathrm{O}$ tombamento é um instrumento de preservação e, portanto, visto como muito restritivo, pois apesar de não desapropriar bens patrimoniais impõe a eles regras de uso e conservação. Isto tem desencadeado uma série de conflitos pelo fato ser aplicado sobre bens de domínio público ou privado, ocasionando obrigações de conservação dos proprietários sob a supervisão do poder público responsável.

Um bem protegido pelo instrumento de tombamento fica submetido a dispositivos jurídicos de forma a impedir descaraterizações ou destruição das qualidades que o levaram a ser objeto de proteção. Porém, nem sempre as diretrizes para conservação são compreendidas pelos proprietários e, na intenção de fazer melhorias em sua propriedade, acabam alterando os atributos originais.

Para RUBINO (1996, p. 98)

o tombamento não é a totalidade do trabalho da preservação - pois esta inclui inventário, inscrição, restauro, monumentalização, museus etc. enfim, toda a história que o bem atravessa antes e após ser inscrito em um livro de tombo - é o momento mágico da classificação. É quando se fixa o que antes se encontrava solto, se destaca e se distingue o que era parte de um contínuo, quando se agrega o que era fragmentado. Ao ganhar um número de inscrição o bem adquire uma segunda existência: passa a fazer parte do modelo reduzido de um país imaginado.

Os bens culturais reconhecidos por meio do tombamento devem ser inscritos em um dos quatro livros de tombo e museus sugeridos no Decreto-Lei:

1. Livro do Tombo Arqueológico, Etnográfico e Paisagístico, onde são inscritos os bens culturais em função do valor arqueológico, relacionado à vestígios da ocupação humana pré-histórica ou histórica; de valor etnográfico ou de referência para determinados grupos sociais; e de valor paisagístico, englobando tanto áreas naturais, quanto lugares criados pelo homem aos quais é atribuído valor à sua configuração paisagística, a exemplo de jardins, mas também cidades ou conjuntos arquitetônicos que se destaquem por sua relação com o território onde estão implantados.

2. Livro do Tombo Histórico, onde são inscritos os bens culturais em função do seu valor 
histórico. É formado pelo conjunto dos bens móveis e imóveis existentes no Brasil e cuja conservação seja de interesse público por sua vinculação a fatos memoráveis da história do Brasil. Esse Livro, para melhor condução das ações do Iphan, reúne, especificamente, os bens culturais em função do seu valor histórico que se dividem em bens imóveis (edificações, fazendas, marcos, chafarizes, pontes, centros históricos, por exemplo) e móveis (imagens, mobiliário, quadros e xilogravuras, entre outras peças).

3. Livro do Tombo das Belas Artes, onde são inscritos os bens culturais em função do seu valor artístico. $\mathrm{O}$ termo belas-artes é aplicado às artes de caráter não utilitário, opostas às artes aplicadas e às artes decorativas. Para a História da Arte, as belas artes imitam a beleza natural e são consideradas diferentes daquelas que combinam beleza e utilidade.

4. Livro do Tombo das Artes Aplicadas, onde são inscritos os bens culturais em função do seu valor artístico, associado à sua função utilitária. Essa denominação (em oposição às belas artes) se refere à produção artística que se orienta para a criação de objetos, peças e construções utilitárias: alguns setores da arquitetura, das artes decorativas, design, artes gráficas e mobiliário, por exemplo. Desde o século XVI, as artes aplicadas estão presentes em bens de diferentes estilos arquitetônicos.

Cada unidade da federação ou município pode estabelecer as categorias necessárias ao enquadramento dos bens localizados em seus territórios bem como a discriminação dos seus respectivos livros de tombo. O Estado de São Paulo ${ }^{16}$ adotou a sugestão federal e acrescentou o Livro de Tombo das Artes Populares para os bens relacionados às manifestações folclóricas, estabelecendo a proteção de bens imateriais posteriormente reconhecida na lei maior brasileira, tais como o tombamento nacional do Samba de Roda, no Recôncavo Baiano (Processo ${ }^{\circ}$ 01450.010146/2004-60 de 05/10/2004) e do Fandango Caiçara, no litoral sul do Estado de São Paulo e litoral norte do Estado do Paraná (Processo no 01450.014268/2008-59 de 29/11/2012)

Há sempre a possibilidade política de retirar a proteção de um bem patrimoniado, pois o tombamento pode ser cancelado. No entanto, a força de grupos sociais que inscrevem um bem numa rede de significados patrimoniais luta para que isso não ocorra. Neste sentido não simples nem fácil tombar um bem e destombar ao sabor dos grupos de interesse político.

O revés de proteção foi legitimado, em artigo único, de um decreto-lei em 1941, cabendo, à época, ao presidente da república a determinação do destombamento para atender motivos de interesse público. Essa possibilidade serviu, por exemplo, para atender aos interesses minerários sobre o Pico de Itabirito, no quadrilátero ferrífero de Minas Gerais, o qual havia sido tombado como Patrimônio Natural pelo IPHAN em 1962 e destombado no período da ditadura militar, em 1965. 
Bens foram des-tombados pelo estado de conservação decorrente do descuido de proprietários e dos governantes responsáveis. Exemplos deste descuido foi a demolição das igrejas tombadas Bom Jesus do Calvário e São Pedro dos Clérigos, construídas no século XVIII, para a abertura da Avenida Presidente Vargas no Rio de Janeiro em 1944. O maior interessado na consolidação dessa via foi o responsável pelo despacho de cancelamento do tombamento, ocorrido em 1943, no governo do presidente Vargas. Na cidade de São Paulo a igreja Nossa Senhora do Rosário dos Homens Pretos foi originalmente construída na Rua XV de Novembro, na data aproximada de 1737, onde está localizada a Praça Antônio Prado. No governo de João Teodoro, em 1872, começaram algumas demolições de casas e do antigo cemitério de escravos para criar o Largo do Rosário, sendo mantida a igreja. Na gestão de Antônio da Silva Prado (1899-1911) a cidade passou por diversas obras de saneamento e embelezamento que culminou com a demolição da igreja em 1904, sendo reconstruída, com dimensões menores, no Largo do Paissandu, em 1908, onde está atualmente.

As práticas de invalidação do patrimônio nacional atingiram 14 bens protegidos nacionalmente e ocorreram de forma arbitrária para beneficiar demandas específicas sobre os usos dos espaços e dos recursos paisagísticos, principalmente nos regimes de governos militares, mas também ocorrem no período democrático, como no caso da revisão do tombamento dos bairros jardins em São Paulo, que não foi destombado, mas teve seu decreto significativamente modificado.

Passados 50 anos de atividades patrimoniais no Brasil, um novo entendimento foi estabelecido no artigo 216 da Constituição Federal de 1988, que define patrimônio cultural como "os bens de natureza material e imaterial, tomados individualmente ou em conjunto, portadores de referência à identidade, à ação, à memória dos diferentes grupos formadores da sociedade brasileira, nos quais se incluem:

I - As formas de expressão;

II - Os modos de criar, fazer e viver;

III - As criações científicas, artísticas e tecnológicas;

IV - As obras, objetos, documentos, edificações e demais espaços destinados às manifestações artístico-culturais;

V - Os conjuntos urbanos e sítios de valor histórico, paisagístico, artístico, arqueológico, paleontológico, ecológico e científico".

O termo cultural aparece vinculado ao patrimônio e os bens imateriais, relacionados nos itens I e II, foram então reconhecidos como heranças importantes a serem protegidas. Nessa nova definição, os bens que antes estavam limitados àqueles relacionados ao histórico e ao 
artístico, tornaram-se mais abrangentes e representativos da diversidade cultural do território brasileiro. A Constituição estabeleceu que a promoção e proteção do patrimônio cultural será realizado com a participação popular e ainda prevê outras formas de acautelamento e preservação, daí as possibilidades abertas para muitas formas de participação e também de governança de um bem protegido.

Para a salvaguarda desses bens imateriais, criou-se no ano de 2000 o instrumento "Registro de Bens Culturais de Natureza Imaterial" que deverá ser inscrito em um dos quatro livros especificados: Livro de Registro dos Saberes - associado à produção de objetos e/ou prestação de serviços que podem ter sentidos práticos ou rituais; Livro de Registro das Celebrações - relacionado aos ritos e festividades; Livro de Registro das Formas de Expressão - são as manifestações artísticas que envolvem expressões literárias, musicais, plásticas, cênicas e lúdicas; e Livro de Registro dos Lugares - representam os locais de práticas culturais coletivas como feiras, mercados, praças, cachoeiras, rios, entre outros. Na ocasião, foi criado o Programa Nacional do Patrimônio Imaterial (PNPI) - e consolidado o Inventário Nacional de Referências Culturais (INCR).

Muitos destes dispositivos constitucionais necessitam de leis de regulamentação. Portanto, a preservação é um gênero que pode ter uma diversidade de formas ou tipos de proteção do qual o tombamento é dos instrumentos. O uso de uma ou outra tipologia de instrumento jurídico para preservação do patrimônio cultural brasileiro depende do seu desenho normativo. "É a norma infraconstitucional que dirá para que serve cada tipo de instrumento de preservação, sua finalidade, seu objeto e a forma de usá-lo (RABELLO, 2015 p. 4).”

A multiplicidade da tipologia dos bens culturais poderá implicar o uso também diversificado dos instrumentos jurídicos de preservação; e a aplicação diferenciada desses instrumentos jurídicos também acarretará formas e efeitos diferenciados de preservação. Portanto, tombamento é uma forma específica de preservação de bens culturais dirigida a determinados tipos de bens para alcançar aqueles efeitos jurídicos determinados na lei. (RABELLO, 2015 p. 4)

Todo esse caminho percorrido pelas normas, instituições e instrumentos demonstram a riqueza de possibilidades e desafios da proteção do patrimônio cultural. Este termo consagrado e mesmo no senso comum sempre está associada à memória contida nos diversos bens, sejam eles bens tangíveis (grandes monumentos, sítios históricos e obras de arte etc.) ou intangíveis (lugares de realização de manifestações religiosas, tradições culturais, música entre outros). A evolução e extensão do conceito resultam foi sendo construída a partir da própria manifestação dos povos, dos cientistas e também de equipes técnicas dos órgãos de proteção do patrimônio. Trata-se, portanto, de uma "construção social, reunindo indivíduos e grupos em torno de um sentimento de identidade coletiva, visível pelos bens e símbolos preservados por aqueles que aí se reconhecem, incluindo se também a natureza, pois além de provedora de recursos, se 
apresenta como um marco cultural, contribuindo, fundamentalmente para a definição de uma identidade" (MELO, 2015)

Era o poder público que instituiu o patrimônio cultural, o qual só se comporia de bens tombados. O tombamento, portanto, tinha papel instituinte do valor cultural - daquele valor que credenciou a inclusão do bem num rol formalmente definido. Ao inverso, a nova constituição federal reconheceu aquilo que é posição corrente, há muito tempo, nas ciências sociais: os valores culturais não são criados pelo poder público, mas pela sociedade. O patrimônio é antes de mais nada um fato social - essa afirmação nos órgãos de preservação, nas décadas de 1970 e 1980, provocava escândalo e alimentava mal-entendidos". (MENESES, 2009)

O tombamento é, portanto, um dos instrumentos de proteção patrimonial abrangente que foi amplamente utilizado para a tomada de decisão sobre o valor de um bem para a sociedade. No entanto é preciso reconhecer que seria fundamental desenvolver todos os dispositivos constitucionais e ampliar as possibilidades de proteção. Sendo o tombamento um ato preservacionista ele tem muita força, mas gera um impasse quanto às funções de estado e as responsabilidades da sociedade. O tombamento "é antes de tudo, um ato de discernimento cultural, que procura atender às reclamações de muitas vozes e de muitas gerações. Como tal, é um ato de inteligência e de coragem coletiva. Trata-se de uma estratégia trans-ideológica, destinada a ter permanência validade histórica" (Ab’ SABER, 1986 p.3).

\section{Chancela da Paisagem}

Ampliando um pouco o exercício da proteção e gestão patrimonial no território temos o instrumento da Chancela. A Chancela da Paisagem, que é um instrumento de reconhecimento do valor cultural de uma determinada área do território nacional, que possui características especiais na interação entre o homem e o meio ambiente. Foi instituída por meio da Portaria $\mathrm{n}^{\circ} 127$ de 2009 para contribuir na preservação do patrimônio cultural, complementando e integrando os instrumentos de promoção e proteção existentes, pois havia a consciência de que os instrumentos vigentes não contemplam integralmente o conjunto de fatores implícitos nas paisagens culturais.

Quando tratamos da Chancela da paisagem permanece um sentido fortemente de meio rural (Meneses, 2002), mas essa associação já foi mais arraigada nas tomadas de decisões sobre o que deveria ser uma paisagem protegida pela Chancela. A necessidade de considerar a dinâ- 
mica paisagística dos processos naturais e culturais integrados foram decisivos para a criação deste novo instrumentos de proteção.

Muitas paisagens foram protegidas pelo tombamento utilizando unicamente estes dispositivo legal a tratar do paisagístico. Um sítio paisagístico contém a integração histórica e dos processos da natureza e das apropriações culturais. Por exemplo um Morro testemunho de níveis erosivos do passado, um remanescente de vegetação da semiaridez quaternária, ou mesmo um contexto "ou o envoltório natural que confere situação de qualidade estética a um conjunto construído. No entanto, como aponta Scifoni (2016), a proteção da paisagem (natural-cultural) teve durante décadas o tombamento como único instrumento acionado para proteger e indicar caminhos para a gestão de bens paisagísticos utilizando muitas vezes conceitos praticados para outros tipos de bens com outras características, tais como os objetos arquitetônicos. Essa visão, apesar de considerar no paisagístico processos históricos e geoecológicos, não considerou as necessidades específicas destes bens no desenvolvimento de posturas sobre sua proteção. Ao final o que temos é um conjunto de tombamentos de paisagens cuja gestão é bastante dificultosa em função do não desenvolvimento e consolidação de um repertório conceitual, teórico e técnico específico para proteção da paisagem.

A motivação para adoção de um novo mecanismo de proteção de paisagens deve-se ao novo sentido dado ao patrimônio na Constituição de 1988 e à introdução da categoria "paisagem cultural" no rol de proteção da UNESCO em 1992. A proposta dessa organização internacional inclui critérios e tipologias de paisagens em que a cultura permeia as interações com o ambiente, seja pelas atividades desenvolvidas e/ou vínculos afetivos associados, numa tentativa de se aproximar dos conceitos desenvolvidos na geografia cultural, principalmente nas obras de Carl Sauer, que entendia que a cultura é o agente determinante dessas paisagens (Meneses, 2002).

As três classes principais que a Unesco propõe como critérios operativos para analisar a paisagem cultural são as seguintes:

- Paisagens projetadas e criadas pelo homem - representadas por parques e jardins construídos por razões estéticas que podem estar associados ou não a edificações. A vegetação constitui o elemento principal de inspiração do planejamento desses espaços.

- Paisagens evoluídas organicamente - São aquelas representadas pelos processos evolutivos na forma e seus componentes. Podem ser paisagens que permanecem vivas (sistemas agrícolas em operação) ou que testemunhem sistemas pretéritos (paisagens industriais obsoletas). A manutenção dos modos de vida tradicionais e de um papel social ativo na sociedade contemporânea têm sido considerados fatores importantes de credenciamento destas paisagens.

- Paisagens associativas - São consideradas as fortes associações artísticas, religiosas ou culturais com o elemento natural, em vez de evidências culturais materiais, que podem ser insignificantes ou mesmo ausentes. 
O Conselho da Europa em 1995, discutiu a conservação das paisagens culturais ameaçadas, no âmbito do ordenamento territorial e produziu o documento "Recomendação da Europa", retomando e acentuando a importância das paisagens abrindo o caminho para a o delineamento de diretrizes na Convenção Europeia da Paisagem, realizada em 2000 na cidade de Florença/ Itália. Três aspectos ${ }^{17}$ podem ser destacados desta Convenção:

- Incorporação da ideia de transformação: "Gestão da paisagem”. Esta ação visa assegurar a manutenção da paisagem, numa perspectiva de desenvolvimento sustentável, no sentido de orientar e harmonizar as alterações resultantes dos processos sociais, econômicos e ambientais;

- Incorporação da perspectiva simbólica: "Paisagem" designa uma parte do território, tal como é apreendida pelas populações, cujo carácter resulta da ação e da interação de fatores naturais e/ou humanos;

- Gestão Participativa: Construir procedimentos para a participação das pessoas, das instituições locais e autoridades regionais, e de outros intervenientes interessados na definição e implementação das políticas da paisagem

A convenção Europeia influiu em muitos países que passagem a discutir e buscar caminhos para proteção de suas paisagens. No Brasil essa iniciativa resultou na elaboração da Carta de Bagé em 2007, motivada pela proteção das paisagens do território dos Pampa, das paisagens culturais de fronteira, ameaçadas por usos predatórios, como o reflorestamento de grandes extensões resultando em forte ameaça à biodiversidade dos campos sulinos, dos mananciais e a sociodiversidade da região. A Carta de Bagé prevê medidas de intervenção e preservação que envolvem identificação, proteção, inventário, registro, documentação, manutenção, conservação, restauração, recuperação, renovação, revitalização, restituição, valorização, divulgação, administração, uso, planejamento e outros; mediante certificação ou chancela, com valor de proteção legal, concedida pelos órgãos de patrimônio (FIGUEIREDO, 2014).

O instrumento da Chancela passa a ser tematizado nos órgãos do patrimônio, lembrando que por meio dela, ficam assegurados o reconhecimento e o respeito aos valores éticos, estéticos, ambientais, ecológicos, econômicos e culturais da paisagem, em sua relação com as comunidades. (BRASIL, 2009).

Para celebrar a assinatura da chancela da paisagem em um território torna-se necessário a definição prévia de um pacto de gestão entre os diversos atores sociais que tem vínculos com este território e sobretudo com a paisagem a ser protegida. Isto pressupõe um reposicionamento dos agentes do Estado em relação à participação social na gestão.

As primeiras experiências com este instrumento mostram uma série de questões. Melo 
(2015) estudando a Chancela da paisagem cultural da cidade do Rio de Janeiro, discute as questões de planejamento e dos desenhos de proteção de paisagens culturais como um grande desafio. Para Meneses (1998) é indispensável que a preservação da paisagem se faça sempre nos quadros da gestão territorial.

A compreensão de que as paisagens e as culturas a elas associadas estão ameaçadas por fenômenos como expansão urbana, padronização de costumes, banalização do valor cultural das paisagens históricas e massificação das paisagens urbanas e rurais, cria a necessidade de ampliar a adoção de estratégias que envolvam a participação social e gestão colaborativa ou co-gestão dos envolvidos no território chancelado. Apesar do imenso desafio essa postura indica um avanço importante nas práticas patrimoniais, pois "legitima os direitos das comunidades sobre seus os territórios e sobre seus costumes e mostra que a cultura está sendo revalorizada como um recurso para o desenvolvimento sustentável” (LEFF, 2001, p.61).

Nosso contexto de políticas públicas participativas passa por imensos desafios. Numa perspectiva avaliativa da proteção da paisagem cultural Melo (2015) ressalta que não há no instrumento "não há uma definição quanto ao conteúdo do pacto para a gestão compartilhada, limitando-se a indicar de forma facultativa a pluralidade de atores que podem participar deste processo e a possibilidade deste vir a ser integrado em um plano de gestão acordado entre as diversas entidades, órgãos e agente públicos e privados envolvidos”. Isto revela que não há uma orientação quanto a composição o que pode levar a uma balança muito desigual de forças sociais num território francamente em disputa.

Também há fragilidades quanto a conceituar o conteúdo de uma paisagem cultural. Certo é que é representa um recorte territorial, mas o seu conteúdo ainda precisa ser especificado diante da ampla polissemia, que salvo melhor juízo, pode incorrer em exclusões importantes da interação sociedade e natureza. A ideia de um conjunto espacial representado por morfologias e dinâmicas naturais apropriadas por um certo uso que constitui a referência valorizada socialmente, mas como delinear essa porção territorial ainda é vago. Neste sentido é importante destacar que

\footnotetext{
"A chancela parte do princípio de que os ambientes podem ser dotados de significados culturais, uma vez que o homem no decorrer da história manipulou o meio físico para expressar nele sua cultura. Assim, uma mesma porção territorial pode ter ao mesmo tempo valor cultural e ambiental. Juntamente com a legislação ambiental brasileira, a Portaria $n^{\circ} 127 / 2009$ pode contribuir com a preservação da biodiversidade, de ecossistemas e os modos tradicionais de vida" (VASCONCELOS, 2012).
}

No quadro 5 procuramos estabelecer uma pequena síntese comparativa. 


\begin{tabular}{|c|c|c|}
\hline Itens & Tombamento & Chancela da paisagem \\
\hline $\begin{array}{l}\text { Procedimentos para } \\
\text { indicação do bem }\end{array}$ & $\begin{array}{l}\text { Grande parte dos tombamentos } \\
\text { ocorreram sem participação so- } \\
\text { cial. Mais recentemente, qualquer } \\
\text { cidadão pode solicitar abertura de } \\
\text { processo para o tombamento de } \\
\text { um bem. }\end{array}$ & $\begin{array}{l}\text { Qualquer pessoa natural ou jurídica } \\
\text { é parte legítima para requerer a ins- } \\
\text { tauração de processo administrativo }\end{array}$ \\
\hline Finalidade & $\begin{array}{l}\text { Proteção integral. Intervenções } \\
\text { mais restritivas, conforme os graus } \\
\text { de proteção }\end{array}$ & $\begin{array}{l}\text { Preservação dos contextos culturais } \\
\text { complementando e integrando os } \\
\text { instrumentos de promoção e prote- } \\
\text { ção existentes. }\end{array}$ \\
\hline Gestão & $\begin{array}{l}\text { Poder público. Sem Plano de Ges- } \\
\text { tão }\end{array}$ & $\begin{array}{l}\text { Compartilhada pelas partes interes- } \\
\text { sadas. Podendo integrar Plano de } \\
\text { Gestão }\end{array}$ \\
\hline Fiscalização & Poder público & Poder público \\
\hline Decisões & $\begin{array}{l}\text { Poder público e Conselho Consul- } \\
\text { tivo }\end{array}$ & $\begin{array}{l}\text { Poder público e Conselho Consul- } \\
\text { tivo }\end{array}$ \\
\hline Vigência & Indeterminado & $\begin{array}{l}10 \text { anos, podendo ou não ser reva- } \\
\text { lidada }\end{array}$ \\
\hline Abrangência & $\begin{array}{l}\text { Não há recorte espacial. Esse re- } \\
\text { corte depende de uma base concei- } \\
\text { tual. Paisagem Natural x Paisagem } \\
\text { Cultural (conj. Urbanos). }\end{array}$ & $\begin{array}{l}\text { Recorte espacial definido. Envolve } \\
\text { atributos naturais e culturais asso- } \\
\text { ciados (integrados). }\end{array}$ \\
\hline
\end{tabular}

5 - Síntese comparativa dos instrumentos de Tombamento e Chancela da paisagem.

A criação deste conceito no Brasil se apoiou em iniciativas científicas e de organizações profissionais, particularmente dos arquitetos. Alguns princípios que fundamentam a Chancela da paisagem e, que contribuem para uma abordagem geográfica desta questão, foram formulados a partir de uma solicitação da Federação Internacional de Arquitetos Paisagistas (IFLA) à Associação Brasileira de Arquitetos Paisagistas (ABAP) que elaborou em 2010 princípios para alcançar a Convenção Global da Paisagem. Os "Doze Princípios da Carta Brasileira da Paisagem" constituem uma declaração de princípios éticos (que abrange a ecologia, a justiça social e as políticas culturais e econômicas de desenvolvimento) para promover o reconhecimento, avaliação, proteção, gestão e planejamento sustentável de paisagens em cada país, através da adoção de convenções (leis, acordos) que reconhecem a diversidade paisagística e os valores locais, regionais e nacionais, bem como os princípios e processos relevantes para salvaguardar os recursos da paisagem (ABAP, 2010). São eles:

1. A paisagem e seu papel coletivo - deve ser assegurada indiscriminadamente a toda a população brasileira

2. O reconhecimento das paisagens brasileiras e seus ecossistemas - deve se dar a partir da delimitação de seu suporte físico 
3. As relações entre a paisagem e a população - o reconhecimento e o respeito aos seus valores éticos, estéticos, ambientais, ecológicos, econômicos e culturais devem ser assegurados.

4. A paisagem como instrumento de planificação do desenvolvimento sustentável do país - toda a dimensão paisagística (natural e cultural) deve ser incluída nos planos de ordenamento do território e nos projetos de intervenção, considerando a participação das comunidades e o conhecimento popular

5. A paisagem e seu valor econômico para a sociedade brasileira - além das qualidades estéticas e ecológicas, a paisagem é suporte e recurso para diversas atividades produtivas. Populações devem ter suas tradições produtivas reconhecidas, protegidas e avaliadas, e garantida a sua participação nas reformulações sobre as paisagens.

6. Necessidade do respeito e da preservação de nossas paisagens - preservação de morfologias e tipos vegetacionais significativos da memória coletiva dos nossos habitantes. Paisagens de exceção, devido à sua unicidade como testemunhas de uma história climática, evolutiva e cultural, devem ser consideradas como prioritárias à preservação. $\mathrm{O}$ reconhecimento, a partir das comunidades locais e suas referências, dos elementos simbólicos e significativos, a serem preservados dentre suas paisagens cotidianas. Os critérios cênicos e de monumentalidade devem sofrer o acréscimo de outros critérios para a delimitação do que seja patrimônio. Considerar o respeito à paisagem e o direito à paisagem como meios de garantia da cidadania e da própria sobrevivência das cidades.

7. O direito democrático à qualidade ambiental e paisagística - qualidade ambiental e paisagística é direito de todos os brasileiros.

8. Os princípios locais e nacionais para gestão efetiva da paisagem no Brasil - A gestão da paisagem no Brasil, deve ser operacionalizada a partir da identificação de dois princípios gerais constituintes: sua condição física ambiental associada à sua condição físico- ambiental associada a condição socioambiental. A interação entre estes dois princípios vai determinar o grau e a direção de sua vulnerabilidade (sócio e físico-ambiental), cujo controle deve ser o objetivo da gestão nas diferentes escalas.

9. A necessidade da visão integrada para os projetos e políticas governamentais - adoção de uma visão integrada da paisagem com base na sua compreensão como todo o território, incluindo a percepção que se tem sobre ele. Isso possibilita a superação de entendimentos fragmentários relacionados às paisagens adjetivadas: naturais ou culturais, urbanas ou rurais, históricas ou atuais. Também constitui base para uma política da paisagem, como instrumento-guia para uma administração sustentável do território nacional, uma política que compreenda e reconheça a paisagem como 
fenômeno integrado e sistêmico.

10. Intercâmbios paisagísticos na américa através dos grandes compartimentos territoriais de nossas paisagens. - Os intercâmbios paisagísticos devem ser abordados inicialmente dentro de sua unidade de maior escala morfofuncional, que vem a ser o domínio morfoestrutural.

11. As paisagens urbanas em degradação e as relações com o crescimento populacional nas metrópoles - problema a ser enfrentado com novas visões tecnológicas. - Reestruturação de paisagens urbanas degradadas de modo integrado, como propulsores de novas dinâmicas: urbanas, sociais, culturais, biofísicas e econômicas, e de melhoria do quadro de vida da população. Maior controle quanto a densidade construtiva e atenção especial deve ser dada à proteção dos jardins históricos.

12. A realidade das áreas rurais e a necessidade de valorização e restauração de paisagens pioneiras - Proposta de ordenação de áreas rurais através da implementação de atividades agro-silvi-pastoris que contemplem a inter-relação e conservação relativas aos sistemas biofísicos e socioculturais, respeitando as comunidades locais.

\section{Proteção da paisagem no Estado de São Paulo}

Para a proteção das paisagens no Estado de São Paulo, o governo conta com um órgão de Patrimônio: Conselho de Defesa do Patrimônio Histórico, Arqueológico, Artístico e Turístico do Estado de São Paulo (CONDEPHAAT) que instituiu, em 1982, um grupo de pesquisadores $^{18}$ designado para a importante tarefa de elaborar um documento com diretrizes para a proteção das paisagens no território paulista, intitulado "Plano Sistematizador de Proteção das Paisagens do Estado de São Paulo". O ponto de partida foi a análise dos processos de tombamento ${ }^{19}$ abertos pelo órgão, especificamente aqueles referidos genericamente de "quadro natural", relacionados às feições geomorfológicas, às coberturas vegetais nativas, comunidades tradicionais, etc., dotados de qualidades ecológicas, físicas e culturais relevantes. Este grupo de especialistas definiu o conceito de paisagem como a "globalidade dos componentes naturais articulados num determinado contexto espacial e temporal" e, ainda que não incorpore a ação humana nesse sentido, é reconhecida a importância de preservar os atributos culturais presentes nas paisagens.

O documento afirma que toda paisagem é um bem cultural e, portanto, deve ser entendida de modo mais abrangente, para além dos componentes do "quadro natural". Essa pers-

18 Lea Goldnstein, Gil Sodero de Toledo, João Régis Guillaumon, José Pedro de Oliveira Costa, Maria Helena de Almeida Mello e Rodolfo Geiser. 
pectiva se refere aos modos de vida das comunidades sobre o território, que ocorrem de forma harmoniosa, mantenedoras dos saberes tradicionais e dos processos ecológicos e dos recursos naturais, que devem ser alvos de proteção.

Este trabalho orienta as diretrizes para o tombamento de paisagens, que devem considerar: 1) as formas de vegetação nativa remanescentes, em especial as áreas onde a cobertura esteja ameaçada de extinção; 2) as formas de vegetação secundária que se destacam pelo valor científico ou pela escassez de formas originais; 3 ) áreas que se destacam pela existência de monumentos geológicos, de feições geomorfológicas e pedológicas particulares; 4) às paisagens que conservam o equilíbrio do sistema ambiental, garantindo a manutenção dos mananciais; 5) áreas consideradas "habitat" de espécies raras; 6) às paisagens alteradas ou não pela ação antrópica que se destacam pela expressividade, raridade e beleza excepcional representativas pela importância turística, social ou científica. Essas orientações foram elaboradas para servir como um instrumento a mais de preservação do patrimônio, juntamente com outros aplicados em todas as esferas de governo.

Esse trabalho serviu de base para a conceituação e estabelecimento de normas para o tombamento da Serra do Japi, Guaxinduva e Jaguacoara, o Parque Estadual do Jaraguá, a Reserva Florestal da Fundação José Pedro de Oliveira (Fazenda Santa Genebra), Serra do Boturuna, Serra de Atibaia ou de Itapetinga e a Reserva Estadual da Cantareira e o Parque Estadual da Capital (Horto Florestal), todos efetuados em 1983. Importante destacar que o órgão também contratou uma equipe técnica específica para instruir as demandas destes tombamentos. Esta equipe era formada por um geógrafo, uma bióloga e uma antropóloga.

Havia na instituição um grande volume de estudos sobre a proteção paisagística aguardando conclusão. A Serra do Mar, como paisagem de exceção, foi tombada como patrimônio natural em 1985, depois de um longo período de instrução. O autor do pedido de tombamento foi o geógrafo Aziz Nacib Ab'Saber. Para Ab' Saber (1977) 'tudo aquilo que escapa da banalidade topográfica e paisagística, sublinhado por um tipo qualquer de excepcionalidade ecológica e biótica, mereceria desde o início, uma proteção legal”. Essa unidade paisagística estava parcialmente protegida pela legislação ambiental estadual desde 1977, como unidade de conservação de proteção integral e desde 1984 como unidade de conservação de uso sustentável. O tombamento abrangeu vários parques estaduais na Serra do Mar e Paranapiacaba (áreas de proteção integral) e foi mais além, incluiu esporões, praias, restingas, mangues, ilhas e algumas áreas do reverso da escarpa, conforme critérios estabelecidos para os bens naturais. Também abrangeu as infraestruturas da Usina Hidrelétrica de Itatinga, em funcionamento desde 1910, e importante testemunho do processo de eletrificação paulista.

Os critérios considerados no tombamento de áreas naturais, independentemente da ordem de grandeza espacial, envolvem, segundo as Diretrizes para uma Política de Preservação de Reservas Naturais do Estado de São Paulo, Ab’ Saber (1977 p. 3): 
1. preservação de áreas críticas e ecologicamente estratégicas, correspondentes a filtros de Biosfera, reservas naturais de preservação obrigatória, amostras representativas de diferentes ecossistemas ou geofácies das paisagens paulistas: Serra do Mar, Escarpas da Mantiqueira oriental, Bocaina, entre outras;

2. tombamento das áreas pelo princípio da distinção entre paisagens consideradas banais e paisagens reconhecidamente de exceção (morros testemunhos, topografias ruineformes, altos picos rochosos, domos de esfoliação, mares de pedras, canyons e furnas, feições cársticas, cavernas e lapas, lajedos dotados de minienclaves ecológicos, ilhas continentais, promontórios e pontas costeiras, estirãncios de praias);

3. uma política de revalorização, controle e planejamento de algumas paisagens de substituição ou de elaboração mais ou menos artificial. Com vistas a um reaproveitamento para fins de turismo e lazer (beirada de lagos feitos pelo homem, velhos hortos em desativação, ilhas e glebas que foram colônias penais, fazendas e sítios do Estado, passíveis de serem transformados em parques regionais ou locais, terras doadas ao Estado ou a ele incorporadas por ações executivas ou por eventuais desapropriações).

Apesar da grande inovação deste processo na década de 1980, é importante destacar que desde a criação do CONDEPHAAT, em 1968, houve uma preocupação à primeira vista, com o patrimônio natural. Nos anos iniciais deste órgão era fundamentado na visão estética e turística, mas o tombamento de alguns patrimônios paulistas já apresentavam a conjugação da dimensão histórica e dos atributos naturais, como por exemplo o Bosque dos Jequitibás (Campinas), O caminho do Mar (Cubatão), Parque da Independência (São Paulo), Parque das Monções (Porto Feliz), Horto Florestal de Rio Claro, Maciço da Juréia (Peruíbe), todos protegidos na década de 1970. (Scifoni, 2006)

As diretrizes estabelecidas por geógrafos no interior da instituição, para as paisagens e áreas naturais, dão uma nova tratativa ao assunto por incluir conhecimentos científicos da ciência geográfica, fortalecendo os pareceres a favor da proteção frente às contestações encaminhadas por loteadores, mineradores, proprietários de grandes glebas e empresas de serraria e abrindo portas a favor das paisagens paulistas. Serra do Mar é um exemplo emblemático desta questão. 
Áreas envoltórias ou entornos

As áreas envoltórias ou entornos referem-se às extensões localizadas nas proximidades do bem protegido, em que há relação ou vínculo com o patrimônio. Marchesan (2011, p. 2) elucida que estas conformam uma paisagem que pode ser composta de vazios, cheios, bens imóveis, móveis, naturais e artificiais. A constituição da área de entorno pode ser extremamente ampla, contando com todos os elementos que integram aquele espaço previamente delimitado como tal e que, por sua natureza, pode ser tanto urbano como rural.

Mas também pode ter dimensões reduzidas, mas não menos importantes, para expressar o fato cultural em questão. Independentemente da extensão espacial, o bem cultural e sua envoltória devem ser compreendidos como um conjunto de atributos naturais e culturais complementares no contexto histórico, social e geográfico compartilhados no espaço.

Para a existência da área envoltória, é necessário o estabelecimento do tombamento como critério de proteção do bem cultural, pois é no estudo que fundamenta a proteção de um bem que se define como o entorno deve ser ordenado para garantir essa proteção.

De acordo com Marchesan (2011, pág. 4)

toda a zona adjacente definida como envoltória ou de entorno assume um caráter instrumental na proteção do bem tombado. Assim, o entorno não se confunde com o bem tombado. Ele se resume a uma determinada superfície espacial incorporada à tutela dos bens culturais pela sua relação, conexão, participação literária (de entendimento), de fruição e conservação do bem dotado, esse sim, de valor intrínseco. Dessa forma, pode-se defini-lo como uma técnica de proteção, um aliado a mais na compreensão do bem cultural tombado.

Sobre as áreas envoltórias incidem diretrizes de uso da terra, geralmente determinados nos planos de ordenamento territorial municipais e, aos planos, podem ser incorporados zonas de proteção do patrimônio histórico, cultural, ambiental e paisagístico com a finalidade de manter a visibilidade, a integridade física, a fruição, a ambiência e a memória do fato cultural em questão.

Algumas tratativas que norteiam, além dos usos e proteção, a definição dos limites da área envoltória, foram propostas, em 1992, nos estudos de Ulpiano T. Bezerra de Meneses, intitulado "Sugestões para o tratamento do entorno de bens imóveis tombados pelo Condephaat" (SCIFONI, 2008, pág. 97). A necessidade de empregar uma fundamentação teórica, até então insuficiente, para a regulamentação do entorno demonstra a importância dessas áreas para a conservação do patrimônio. Foi assimilada a compreensão de que os bens tombados compõem, 
com o contexto em que estão inseridos, um "ambiente", referindo-se às paisagens adjacentes, ou a ambiência de um bem considerando suas características. Para as áreas naturais tombadas a ambiência deve ser entendida também no aspecto da funcionalidade do bem tombado, pois a paisagem que as integram faz parte de um sistema.

O documento de Meneses (1992) serviu de base para a regulamentação de perímetros envoltórios de bens de valor ambiental, como o Bosque dos Jequitibás, em Campinas; Parque Modernista e Parque da Aclimação, em São Paulo; e Haras São Bernardo, em Santo André, por exemplo.

Especificamente para entorno das áreas naturais tombadas, inseridas ou contíguas aos espaços urbanos, foram determinadas três tipologias e respectivos critérios (Quadro 6) adotados para regimentar suas envoltórias e que devem levar em conta os seguintes aspectos (Scifoni, 2006 p.97):

- Que a integridade física do bem tombado depende dos fatores do contexto no qual ele está inserido;

- Que a fruição social é uma das justificativas para o tombamento e ela deve se apresentar pelo menos como fruição visual (embora outros níveis sejam o mais desejável), que não pode ser impedida ou dificultada;

- Que o bem tombado compõe com o seu contexto um ambiente para o qual é necessário manter condições de convivência adequada, a chamada ambiência do bem tombado."

\begin{tabular}{|l|l|}
\hline \multicolumn{1}{|c|}{ Tipologia } & \multicolumn{1}{c|}{ Critérios ambientais adotados } \\
\hline Parques e Áreas Verdes & $\begin{array}{l}\text { Assegurar as condições de insolação direta no local, de ven- } \\
\text { tilação, de permeabilidade e manutenção dos níveis freáti- } \\
\text { cos, e valores estéticos da paisagem (composição com a área } \\
\text { do entorno) }\end{array}$ \\
\hline Monumentos Geológicos & $\begin{array}{l}\text { Assegurar os valores estéticos da paisagem, de modo a evi- } \\
\text { tar o isolamento do contexto paisagístico; integridade física } \\
\text { desses suportes (diretamente relacionada à intervenções no } \\
\text { subsolo) }\end{array}$ \\
\hline $\begin{array}{l}\text { Paisagens de Montes Mor- } \\
\text { ros e Serras }\end{array}$ & $\begin{array}{l}\text { Assegurar as condições de insolação direta, ventilação, per- } \\
\text { meabilidade e manutenção dos níveis freáticos, valores esté- } \\
\text { ticos da paisagem e a integridade física dessas áreas (direta- } \\
\text { mente relacionada aos usos da terra no entorno) }\end{array}$ \\
\hline
\end{tabular}

Quadro 6 - Tipologias e critérios estabelecidos para a regulamentação de áreas envoltórias de bens naturais tombados. Fonte: CONDEPHAAT, 1992. Org. Giorgia Limnios.

O documento ainda sugere que para cada área natural tombada, os critérios para a regulamentação das áreas envoltórias devem ser ponderados de acordo com as condicionantes 
locais, adotando-se pesos diferenciados para a setorização, conforme a expressividade dos atributos naturais ou antrópicos presentes, além do estabelecimento de zonas de proteção de diferentes gradações.

A adoção desses critérios tem como objetivo não só a proteção do bem tombado, como também da paisagem local, com grandes benefícios sociais e ambientais.

Nos estudos de RUIZ (1995, p. 2) para a determinação do entorno dos bens protegidos em áreas urbanas o autor pontua algumas exigências que irão determinar o conhecimento e composição dessas áreas em relação ao bem. São os seguintes parâmetros urbanísticos:

- Proteção física: monitoramento das edificações em mal estado existentes nas imediações, controle de ruídos e de contaminantes industriais que possam afetar o bem, etc.

- Significação e visualização: a identificação como "lugares" dos bens imóveis conjuntamente com seu entorno, a integração do bem imóvel na paisagem, a valorização das perspectivas estéticas consolidadas histórica e/ou coletivamente, etc.

- Uso: ordenação e resolução das demandas de conexão, segundo as funções do bem imóvel, que possam existir entre o (bem imóvel cultural) BIC e seu entorno com a finalidade de satisfazer adequadamente a função do bem.

- Proteção dos espaços relacionados historicamente: todos aqueles que, sem dispor de outra proteção superior, são necessários para o entendimento da histórica conexão do BIC com seu meio.”

Estes indicativos devem sempre considerar as relações paisagísticas com o contexto da paisagem predominantemente natural, portanto varia com suas tipologias.

Para RUIZ (1997, p. 662)

Ao que se refere ao bem, sua localização, sua extensão, sua composição espacial, a histórica importância de suas relações paisagísticas e sua apreciação, etc., serão alguns aspectos a ter em conta. Ao que se refere ao meio, sua condição fechada (montanhas que rodeiam o imóvel) ou aberta (monumento sobre um vale, por exemplo) seu grau de transformação, sua situação jurídica (se se trata de espaços protegidos ou não), etc. serão aspectos que vão condicionar a inserção espacial do entorno."

Na legislação do Estado de São Paulo, por meio do Decreto n 13.426 , de 16/03/1979, o 
entorno foi determinado pelo raio de 300 metros a partir dos limites de qualquer edificação ou sítio tombado para a proteção da visibilidade. Essa métrica vigorou até 2003, quando um novo decreto (Decreto 48.137, de 07/10/03) estabeleceu que as dimensões das áreas envoltórias serão definidas caso a caso, quando estas áreas "se revelarem aptas a prejudicar a qualidade ambiental do bem sob preservação". Essa nova redação não garante a existência das áreas envoltórias, pois se não for reconhecido algum dano sobre a qualidade ambiental do bem protegido, algo bastante específico, pode-se livrar a proteção envoltória de diversas tipologias do patrimônio cultural, deixando-os ainda mais suscetíveis à especulação desses espaços, principalmente nas áreas urbanas mais valorizadas.

Foi o que aconteceu com o entorno de alguns bens tombados na cidade de São Paulo, a exemplo do Colégio Sion, localizado no valorizado bairro de Higienópolis. Quando foi publicada a resolução de tombamento do edifício pelo seu valor histórico, arquitetônico e ambiental, na data de 11/11/1986, não houve considerações específicas sobre a área envoltória, prevalecendo, portanto, o raio de 300 metros a partir dos seus limites. Na resolução publicada em 2015, que redefine a área envoltória, o novo limite foi estabelecido pelas calçadas adjacentes ao bem tombado, na Avenida Higienópolis e Rua Maranhão, sob a alegação de que não há elementos que agreguem valor à qualidade ambiental do patrimônio, além da área apresentar verticalização consolidada. Essas alegações são bastantes pertinentes quando se pretende, por interesses particulares ou de minorias, um entorno zero, ou quase zero, para áreas muito valorizadas e alvos de exploração urbanística. É como desconectar o bem protegido do contexto ao qual estava inserido.

Na data de 13/11/2013 foi publicado um "pacote" de resoluções que redefinem as áreas envoltórias de diversos bens tombados situados na Avenida Paulista, a saber: Casa das Rosas ${ }^{20}$, E.E.P.G Rodrigues Alves ${ }^{21},{ }^{22}$, Casarão ${ }^{23}$ na Avenida Paulista, Parque Trianon. Todos possuíam área envoltória de 300 metros, o que garantia, pelo menos, a manifestação do Condephaat para aprovação ou não de intervenções nas proximidades dos bens tombados. Com a redefinição do entorno, todas essas referências culturais passaram a ter as calçadas adjacentes como limites envoltórios. Os textos com as justificativas para os novos limites são praticamente iguais, com pequenas variações, com a falsa ideia de que "área envoltória já não contemplava ocupação merecedora de proteção, apresentando, atualmente, verticalização consolidada que carece de qualquer função que permita evitar eventual prejuízo à qualidade ambiental do bem protegido" (Diário Oficial, Executivo I, 13/11/2013, p.59).

Por outro lado, o critério da "distância fixa parece pouco apropriado, já que impede reconhecer na delimitação do entorno, a singularidade espacial e, também, jurídica de cada

20 Resolução SC 101, de 01-11-2013

21 Resolução SC 102, de 01-11-2013

22 Resolução SC 103, de 01-11-2013

23 Resolução SC 104, de 01-11-2013 
bem imóvel e de cada meio onde se encontra..." (RUIZ, 1997, p. 642), destarte para os demais bens protegidos. Portanto, se as medidas fixas antes adotadas na legislação estadual, não eram eficazes aos objetivos de proteção, a ausência de parâmetros mínimos na definição dos limites envoltórios também não avança como solução desta questão. Essa nova jurisprudência não fortalece as ações de conservação do patrimônio natural e cultural, não valoriza a importância dos instrumentos de proteção, além do próprio bem protegido, e abre-se precedentes para usos da terra incompatíveis. Contrariamente, a área envoltória determinada caso a caso pode ser a melhor maneira de alcançar os objetivos de proteção, desde que haja afastamentos mínimos que assegure a existência desses espaços.

A determinação de área envoltória mínima em lei, desde que seja possível adequá-la de acordo com estudos técnicos, "ampliaria o grau de segurança jurídica e reforçaria, a atuação reguladora dos órgãos vinculados à preservação”. (MARCHESAN, 2011, pág. 20). Ainda, segundo a autora, o entorno maximiza a proteção do bem tombado e assim o definiu como uma "técnica de proteção", auxiliando na compreensão do bem cultural tombado.

Algumas recomendações internacionais destacam a importância das áreas envoltórias como uma estratégia na proteção dos bens; como foi previsto nas Normas de Quito - Reunião sobre Conservação e utilização de monumentos e lugares de interesse histórico e artístico OEA (Organização dos Estados Americanos) em 1967. Como medida legal, foram sugeridas zonas de proteção com diferentes condicionantes, conforme a proximidade espacial dos núcleos ou conjuntos monumentais e de interesse ambiental, ou seja, quanto mais próximas forem as zonas da área de interesse, maior será a restrição de uso.

- Z Zona de proteção rigorosa, que corresponderá a de maior densidade monumental ou de ambiente;

- Z Z Zona de proteção ou respeito, com maior tolerância;

- Zona de proteção da paisagem urbana, a fim de procurar integra-la com a natureza circundante.

Outra recomendação internacional, que trata especificamente das áreas envoltórias, refere-se à Declaração de Xian sobre a Conservação do Entorno Edificado, Sítios e Áreas do Patrimônio Cultural, publicada em 2005. No documento, é reconhecido que o entorno contribui para o significado dos monumentos, sítios e áreas de patrimônio cultural, pois é parte integrante tanto nos aspectos físicos e visuais como também nas práticas sociais e espirituais, nos costumes e conhecimentos tradicionais, além de outros aspectos. Assim, o patrimônio só tem sentido quando é compreendido por essas relações que o estruturaram.

A preservação de um entorno coerente com o bem cultural - além de ser fundamental para conservar sua autenticidade e sua história - ajuda a 
manter a memória dos habitantes do local onde esse bem se situa, favorecendo os sentidos de identidade e pertencimento, os quais contribuem ao equilíbrio emocional da população e melhor qualidade de vida. (MARCHESAN, 2011, p.5)

\section{Patrimônio industrial}

O patrimônio industrial paulista é representado por diversas tipologias que envolvem engenhos, usinas hidrelétricas, fábricas, estações ferroviárias e complexos ferroviários. (Mapa 1) A grande maioria corresponde ao período compreendido entre a segunda metade do século XIX e as primeiras décadas do início do século XX, período conhecido como Segunda Revolução Industrial. A estruturação espacial e temporal destes patrimônios industriais tem estreita relação entre eles, bem como a expansão de núcleos urbanos. As novas técnicas que transformaram o trabalho manual em mecânico, o novo mundo das tecnologias das máquinas que surgiam, possibilitou expandir as fronteiras de produção e circulação.

Essa fase industrial é marcada pelas inovações no campo científico e tecnológico aplicados na geração de energia, nos transportes, comunicações e nas fábricas pela incorporação e/ ou aperfeiçoamento das máquinas, para elevar a produção de produtos e serviços, assim como o uso de novos materiais. O que estava circunscrito nos países mais desenvolvidos da Europa e América do Norte, rapidamente se espalhou aos demais Estados europeus e continentes e, o Brasil assimilou bem inovações. No território paulista, o desenvolvimento industrial ocorreu, com mais ênfase, na cidade de São Paulo, muito determinado pela existência de um centro urbano estruturado e pela proximidade com o porto de Santos, para depois alcançar novas áreas, desenvolvendo cidades, modificando as paisagens e o cotidiano social.

Para melhor compreender como algumas atividades industriais foram instituídas nos lugares é preciso olhar a paisagem, pois a organização de sistemas permanentes e complexos tem estreita relação com os sítios onde foram instalados. A implementação de usinas hidrelétricas, por exemplo, depende do suporte geológico do canal fluvial, altura da queda d'água, vazão do rio e amplas áreas para acomodação das estruturas. O traçado ferroviário prioriza terrenos planos, com pouca inclinação por isso, muitas ferrovias "acompanham" os cursos d' água, as curvas de nível quando possível, caso contrário quando o relevo é dissecado, pontes, túneis, sistemas de cremalheira possibilitaram a estruturação deste meio de transporte. Muitas fábricas foram instaladas nas margens do curso d'água, seja pela necessidade deste recurso, seja por causa da proximidade dos aglomerados urbanos que se desenvolviam próximos aos rios. A paisagem era, e ainda é, o suporte e fonte de recursos necessários para a operação industrial. 


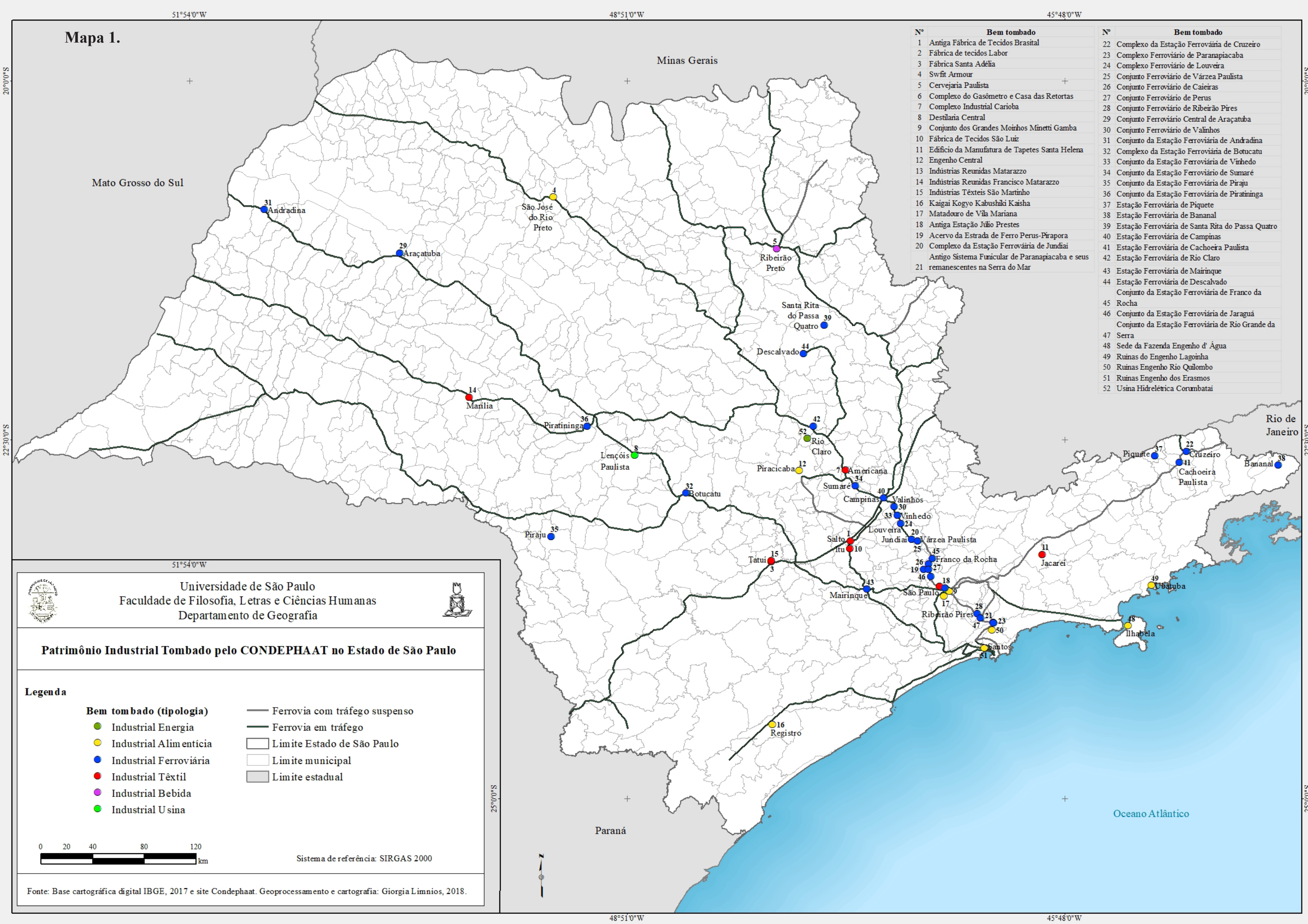


A implementação da industrialização significou o desenvolvimento da complexidade social e produtiva. Por um lado, foram criadas relações entre empresas do mesmo setor, entre empresas de diferentes setores, entre centros de produção e centros populacionais e centros de produção e o ambiente natural. O resultado deste processo é a configuração de paisagens industriais formadas principalmente por centros de produção, habitação, centros sociais, vias de comunicação e infraestruturas de serviços, que fazem parte da identidade do território. A paisagem industrial como paisagem cultural é de vital importância para entender o que era a industrialização" (Areces, 2010 p.94)

Os vestígios da indústria e todo o cenário produzido em torno da vida industrial constitui patrimônio industrial por ter valor histórico e muitas vezes arquitetônico e do saber das engenharias industriais. Este grande acervo compreende objetos tecnológicos, memória social, projetos arquitetônicos e objetos e documentos de valor científico. Os "vestígios englobam edifícios e maquinaria, oficinas, fábricas, minas e locais de processamento e de refinação, entrepostos e armazéns, centros de produção, transmissão e utilização de energia, meios de transporte e todas as suas estruturas e infraestruturas, assim como os locais onde se desenvolveram atividades sociais relacionadas com a indústria, tais como habitações, locais de culto ou de educação" (Carta Nizhny Tagil, 2003 p.3).

Essa definição foi apresentada pela Comissão Internacional para a Conservação do Patrimônio Industrial (TICCIH), em conferência realizada na Rússia em 2003, a qual afirma e reconhece a importância de conservar a proteger não somente as edificações, estruturas, processos, objetos vinculados às atividades industriais como também as paisagens e locais, além de outras manifestações tangíveis e intangíveis, considerando preferencialmente os fatos ocorridos a partir da segunda metade do século XVIII.

Ao patrimônio industrial foram indicadas algumas considerações que justificam a proteção e sua importância nesse campo de ação, segundo consta na Carta Nizhny Tagil:

- O património industrial representa o testemunho de atividades que tiveram e que ainda têm profundas consequências históricas. As razões que justificam a proteção do património industrial decorrem essencialmente do valor universal daquela característica, e não da singularidade de quaisquer sítios excepcionais.

- O patrimônio industrial reveste um valor social como parte do registro de vida dos homens e mulheres comuns e, como tal, confere-lhes um importante sentimento identitário. Na história da indústria, da engenharia, da construção, o patrimônio industrial apresenta um valor científico e tecnológico, para além de poder também apresentar um valor estético, pela qualidade da 
sua arquitetura, do seu design ou da sua concepção.

- $\quad$ Estes valores são intrínsecos aos próprios sítios industriais, às suas estruturas, aos seus elementos constitutivos, à sua maquinaria, à sua paisagem industrial, à sua documentação e também aos registos intangíveis contidos na memória dos homens e das suas tradições.

- A raridade, em termos de sobrevivência de processos específicos de produção, de tipologias de sítios ou de paisagens, acrescenta-lhes um valor particular e devem ser cuidadosamente avaliadas. Os exemplos mais antigos, ou pioneiros, apresentam um valor especial.

Essas definições remetem a pontos muito importantes. "Em primeiro lugar, circunscrever o campo de ação e os objetos de interesse, evidenciando-se mais uma vez que a definição engloba todo o processo relacionado à industrialização, incluindo as unidades de produção de energia, os meios de transporte e todo complexo relacionado à unidade de produção, temas esses necessários para uma compreensão mais ampla do processo de industrialização". (Kuhl, 2010)

A paisagem da indústria está registrada na arquitetura dos edifícios de produção, de moradia, de transporte e nos locais de usos coletivos. Verifica-se algumas similaridades arquitetônicas das plantas industriais, pois o objetivo das edificações estava voltado para a funcionalidade produtiva. Assim, formas, volumes, dimensões e organização interna e externa dos espaços correspondem à finalidades específicas e à disponibilidade técnica.

De modo geral, as primeiras pequenas centrais hidrelétricas, não só no Brasil como em outros países, são compostas pela casa de máquinas (ou casa de força) e estruturas a ela conectadas como barragens, canal de adução, condutos, comportas e subestação. Em muitos casos, foram construídas vilas residenciais para os funcionários, além de escolas de ensino primário. Dependendo da localização e do distanciamento em relação aos centros urbanos o conjunto comportava áreas de lazer como cinema e campos de futebol, local para a prática religiosa como capela ou igreja, mercado e sistema de transporte de bondes. A arquitetura do edifício da casa de máquinas, geralmente, é constituída de planos retangulares, praticamente livre de divisões internas, com um ou mais níveis, grande porta do corpo central, composta de duas folhas, grandes janelas frontais e laterais retangulares ou em conjunto com janelas semicirculares, em caixilho de madeira ou pedra. As edificações foram construídas em alvenaria de tijolos ou pedras. Os acabamentos são constituídos de ladrilho hidráulico, os ornamentos expressam delicadeza e bonito detalhamento moldados em ferro, em bronze, em concreto ou trabalhados na rocha, a exemplo de mãos francesas, luminárias, guarda corpo, escadas, fechaduras, fachadas, etc.

Diversas obras arquitetônicas apresentam características que as associam a determinados momentos históricos, como os estilos e materiais empregados ou, ainda, quando apre- 
sentam inscrições do ano em que foram instituídas. Muitos equipamentos industriais também revelam seu momento histórico e sua origem, muitas vezes inscritos nas placas de identificação do fabricante.

$\mathrm{Na}$ ocasião em que Mario de Andrade apresentou o anteprojeto de Lei em 1936, as técnicas e processos industriais foram reconhecidas como pertencentes às categorias de artes aplicadas, nacional e estrangeira, com exposição dos objetos em Museus de Artes Aplicadas e Técnica Industrial. Tal manifestação, especificamente relacionado ao café, como arte foi motivo de contestação e antes que fosse excluída da jurisprudência de 1937, foi assim esclarecida pelo autor:

\footnotetext{
Arte é uma palavra geral, que neste seu sentido geral significa a habilidade com que o engenho humano se utiliza da ciência das coisas e dos fatos. [...] Imagine-se a "Sala do Café", contendo documentalmente desde a replanta nova, a planta em flor, a planta em grão, a apanha da fruta; a lavagem, secagem, os aparelhos de beneficiamento, desmontados, com explicação de todas as suas partes e funcionamento; o saco, as diversas qualidades de café beneficiado, os processos especiais de exportação, de torrefação e de manufatura mecânica (com máquinas igualmente desmontadas e explicadas) da bebida e enfim a xícara de café. Grandes álbuns fotográficos com fazendas, cafezais, terreiros, colônias, os portos cafeeiros; gráficos estatísticos, desenhos comparativos, geográficos, etc., etc. Tudo o que a gente criou sobre o café, de científico, de técnico, de industrial, reunido numa só sala. E o mesmo sobre algodão, açúcar, laranja, extração do ouro, do ferro, da carnaúba, da borracha; o boi e suas indústrias, a lã, o avião, a locomotiva, a imprensa, etc., etc.
}

\section{A Pequena Central Hidrelétrica como patrimônio}

Em 1973, a Câmara Municipal de Rio Claro solicitou a abertura do processo de tombamento ao Condephaat para a Usina Hidrelétrica de Corumbataí com o objetivo de instalar no edifício o Museu de Energia Elétrica. Nessa ocasião a usina pertencia à empresa estatal Companhia Energética de São Paulo (CESP) e estava paralisada devido à desativação ocorrida três anos antes, após fortes chuvas causarem inundações e rompimentos das barragens. O pedido 
de tombamento tem fundamentação histórica, pois é reconhecida pela municipalidade a importância da usina pelo "pioneirismo na geração de energia elétrica para a iluminação pública no interior do território paulista" (CONDEPHAAT, 1973).

A usina de Corumbataí foi administrada inicialmente pela empresa Real e Portela, e foi tombada pelo CONDEPHAAT, em 16 de abril de 1982, por meio da resolução $n^{\circ} 10$. No rol dos patrimônios industriais paulistas tombados, essa usina é a única representante dos processos e técnicas de geração e transmissão de energia elétrica implantadas no Estado, no final do século XIX e nas primeiras décadas do século XX.

A cidade de Rio Claro foi a segunda localidade brasileira e, a primeira do território paulista, a implantar o sistema de iluminação pública elétrica ocorrido em 1885. Inicialmente, a energia era proveniente de uma usina térmica, inaugurada em dezembro de 1884 . O dínamo "Weston" movido a vapor, a partir de caldeiras aquecidas a lenha, gerava a eletricidade para o centro urbano, mas a iluminação só ocorria nos dias em que não houvesse luar. O relato de uma testemunha sobre o ocorrido na inauguração da usina, em que estava presente o presidente da Província de São Paulo o Sr. Conselheiro Antônio Prado, expõe as falhas desta realização: “... Chovia terrivelmente e as lâmpadas, á medida que eram "ligadas", talvez por defeito nos aparelhos que graduavam o afastamento dos carvões, iam queimando, uma após outra; ao chegarem á décima lâmpada, embora esta queimasse também”. Os problemas na iluminação pública continuaram nos anos seguintes e a ineficiência deste sistema levou a Companhia Mechanica Industrial Rio Clarense, responsável por iluminar a cidade, a planejar a construção da usina hidrelétrica de Corumbataí.

"O Rio Claro correndo sobre rochas basálticas possui alguns mananciais de hulha branca, o que levou a administração previdente do município a construir a pequena usina para a iluminação da cidade”. (Ab’ SABER, 1954, p.7)

O local escolhido para a implantação da hidrelétrica foi a confluência dos rios Corumbataí e Claro, ao sul da área urbana, distante aproximadamente $7 \mathrm{~km}$. As obras foram iniciadas 1892 e a operação é iniciada em 1895, tornando-se a quinta usina hidrelétrica no território paulista, precedida pelas usinas Monjolinho I (1893) no município de São Carlos e Luís de Queiroz (1893) no município de Piracicaba. No mesmo dia da inauguração acontece um incêndio que paralisou as atividades até o ano de 1900, quando foi reinaugurada.

As estruturas da usina passaram por algumas mudanças para assegurar a geração de energia, como o redimensionamento da represa, após as estiagens ocorridas em meados da década de 1910; instalação de uma nova unidade geradora para atender às demandas de eletrificação da Cia. Paulista de Estradas de Ferro, em 1925; reativação da usina térmica e além de outras reformas ocorridas posteriormente. A operação da usina foi paralisada em 1970 após enchentes e as atividades são retomadas quase uma década depois, em 1979. 
O tombamento envolveu as obras, edificações e equipamentos que compõem o sistema da usina (Mapa $\mathrm{x}$ ) sendo discriminados em quatro agrupamentos conforme publicado do Diário Oficial do Estado de São Paulo, em 23/04/1982, páginas 25 e 26: 1) As obras do reservatório do Rio Corumbataí, 2) As obras do reservatório do Rio Claro, 3) As obras e instalações de adução e 4) A Usina Hidrelétrica. As obras dos reservatórios referem-se às infraestruturas compostas pelos próprios reservatórios, às barragens, vertedouros, muros, pontes, extravasores, câmara de pressão e túnel que interliga os reservatórios dos dois cursos d' água. As obras de instalações de adução correspondem à tomada de água do reservatório, ao canal de adução, ao canal de entrada da câmara de pressão, à ponte sobre o canal de entrada, à câmara de pressão, ao canal de fuga (Figura 14) e aos condutos forçados. Por fim, integram ao conjunto da Usina Hidrelétrica a casa de força (Figuras 15 e 16), o edifício anexo à casa de força, onde está localizada a subestação elevadora; o edifício anexo à casa de força, onde está localizada a central térmica; os remanescentes do muro e dos pilares de tijolos aparentes do barracão da caldeira; o duto de tiragem abobadado e a chaminé de tijolos aparentes; os filtros e o reservatório enterrado de água de alimentação da caldeira; o canal de fuga; as pontes sobre o canal de fuga; a caixa d'água; a escadaria do caminho de acesso de pedestres à casa de força; os equipamentos de geração de energia compostos por geradores e turbinas; os equipamentos elétricos de comando, sinalização, controle e proteção; a subestação elevadora e a primeira torre de sustentação da linha de transmissão.

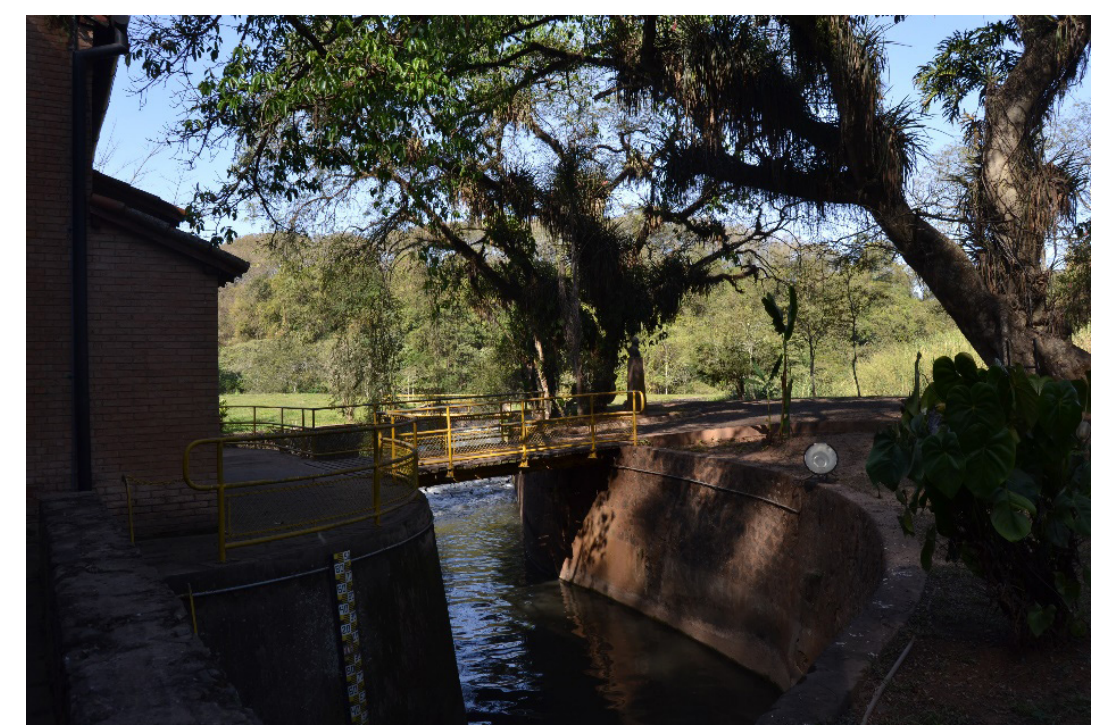

Figura 14 - Canal de fuga Usina Corumbataí. Fotografia: Gildo Magalhães. Data: 21/07/2014. 


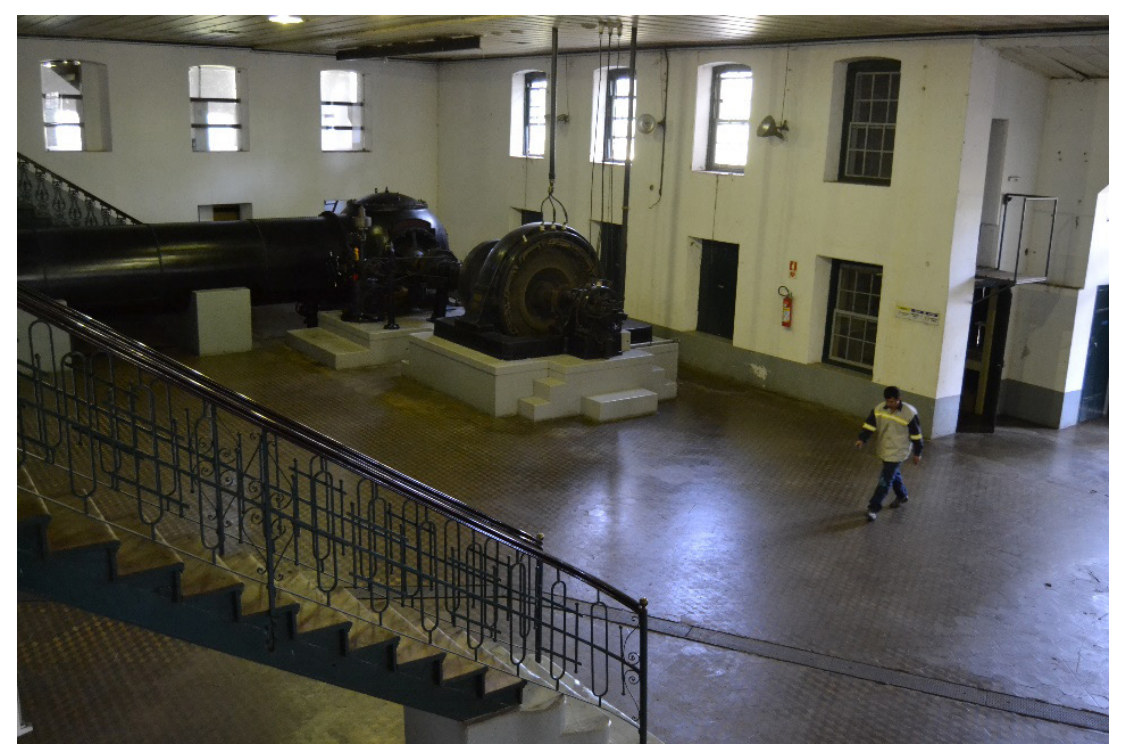

Figura 15 - Casa de máquinas Usina Corumbataí. Fotografia: Gildo Magalhães. Data: 21/07/2014.

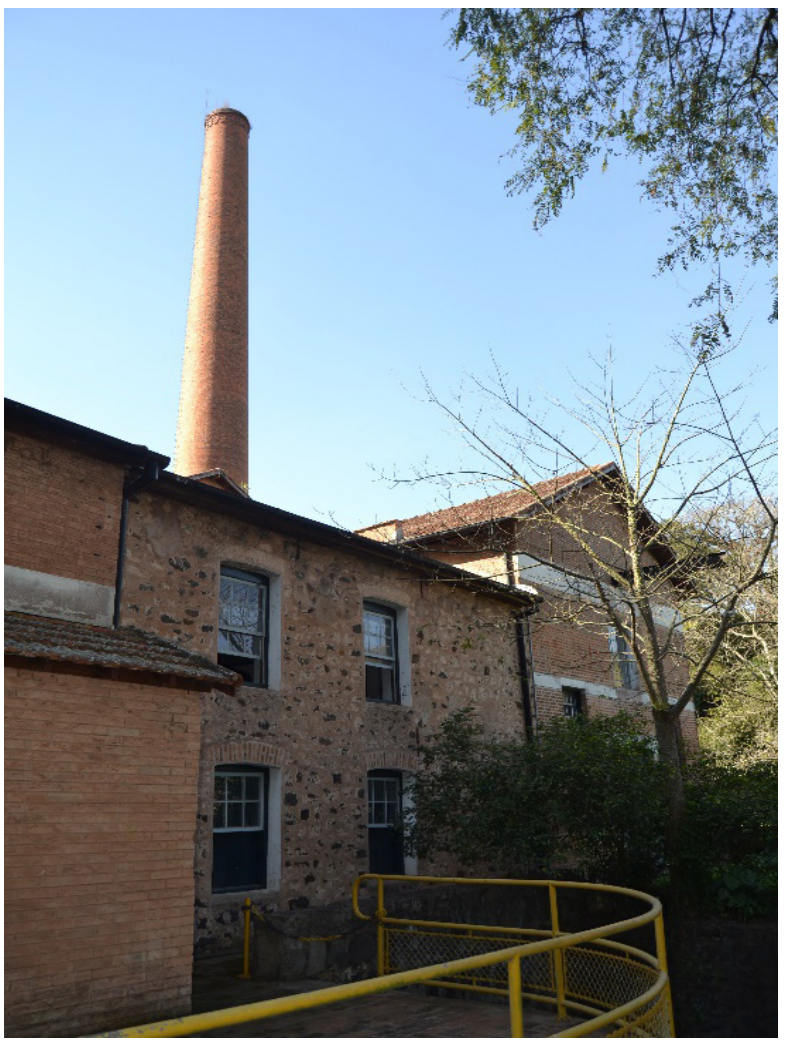

Figura 16 - Fachada casa de máquinas Usina Corumbataí. Fotografia: Gildo Magalhães. Data: 21/07/2014.

A usina possui área envoltória de 55, 20 hectares para proteção do aspecto visual ou qualquer outra característica. Algumas benfeitorias da usina foram incluídas no tombamento com restrição parcial, ou seja, conservam-se as fachadas permitindo alterar o uso, são elas: casa sede e anexos; piscina; sauna; lavanderia; garagem; depósito; casa; caramanchão; bebedouro; viveiro de pássaros; galinheiro; cocheira; pombal e caixa d'água. Para algumas estruturas foram autorizadas demolições ou remoções para recomposição do perfil do terreno: ponte; oficina e 
casa do diesel. Para outras, não houve qualquer proteção, porém, encontram-se localizadas na área envoltória estabelecida: quiosque, telheiro, pocilga, galpão de recreação, caixa d'água, abrigo para caprinos, quadra de tênis, campo de futebol, parque infantil, galpão, escritório, almoxarifado, diversas casas, forno, piscina infantil, cabine de alta tensão, guarita, heliporto, estrada de acesso, estrada de acesso à usina, estrada de acesso à barragem, estrada de serviço, estrada de serviço, ponte.

Nota-se que os locais destinados ao lazer, à moradia (Figura 17, ao abrigo de animais e alguns locais de trabalho, construídos para os operários e suas famílias, não foram incluídos na proteção do tombamento. Mesmo estando na área envoltória, que requer anuência do Condephaat para qualquer intervenção, esses locais de convivência não foram considerados como parte da memória e da história do setor energético paulista.

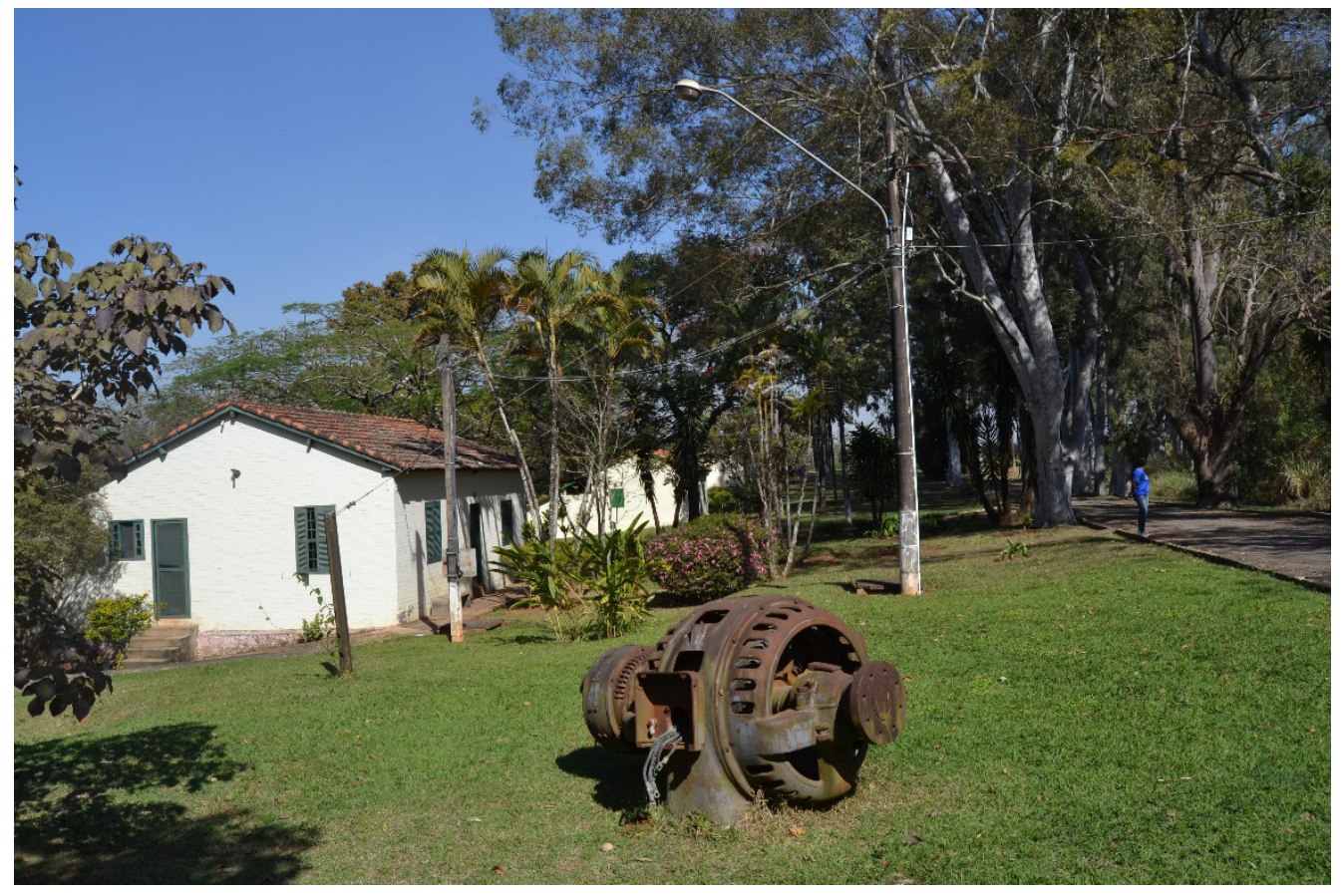

Figura 17 - Vila operária Usina Corumbataí. Fotografia: Gildo Magalhães. Data: 21/07/2014.

A vegetação localizada na paisagem que envolve a usina também recebeu menção para a conservação. A mata presente nas margens do Rio Corumbataí e Ribeirão Claro devem preservadas e onde há necessidade de recomposição, deverá ser efetuado conforme projeto botânico, inclusive nas margens das represas. Os renques de eucaliptos localizados na entrada da usina também deverão ser conservados, pois esses plantios serviam como fonte de energia para o aquecimento das caldeiras da usina térmica e, possivelmente, podem ter sido plantados pelo engenheiro agrônomo Edmundo Navarro de Andrade, devido às diversas pesquisas dedicadas a esse gênero botânico e pela implantação do Horto Florestal de Rio Claro em 1909, basicamente constituído de eucaliptos. 


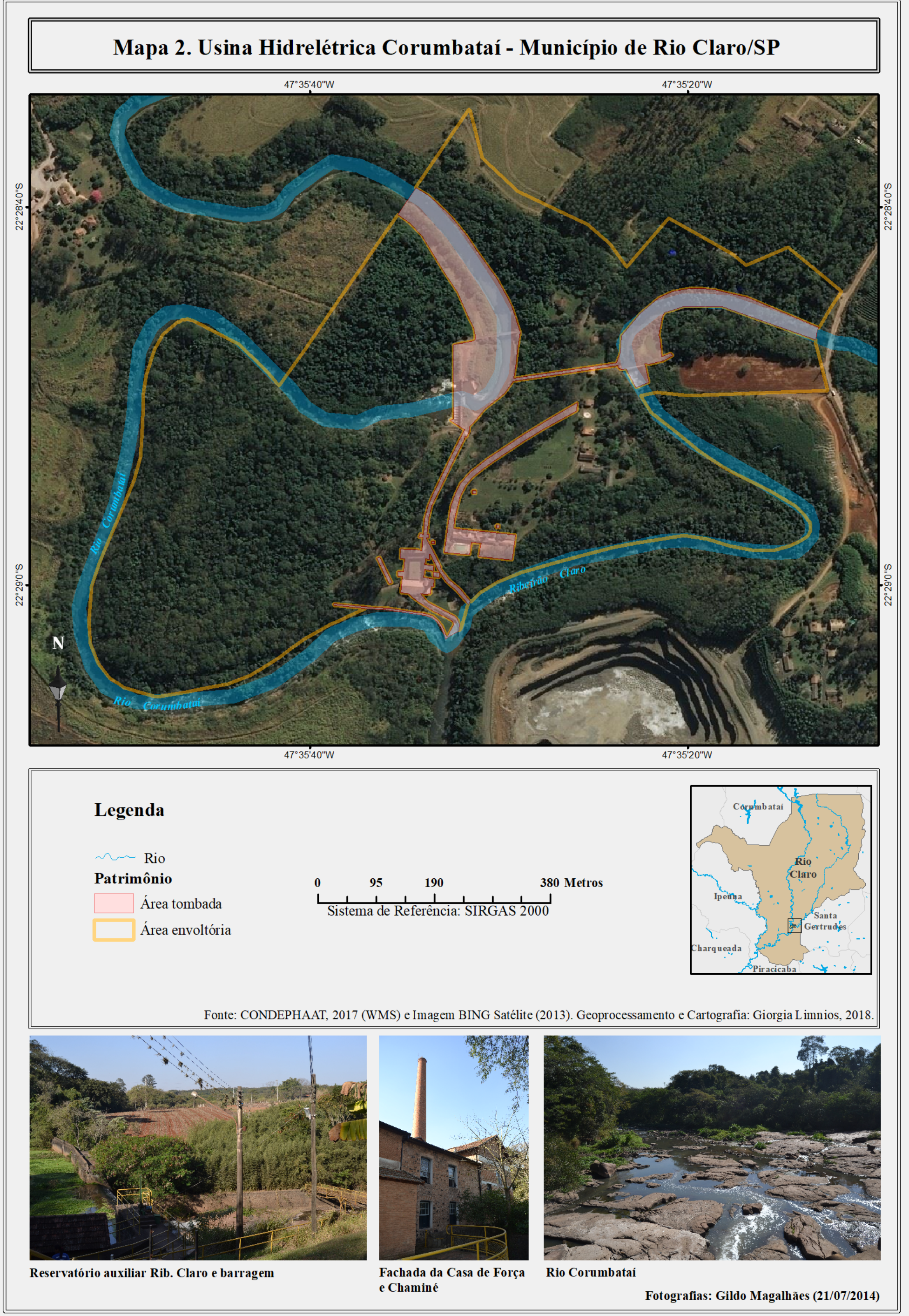




\section{Usina-Parque}

As usinas-parque são constituídas por pequenas centrais hidrelétricas doadas pela CESP e EMAE à Fundação de Energia e Saneamento de São Paulo no final de década de 1990. O conjunto envolve as instalações das usinas Corumbataí (1895), São Valentim (1911) Jacaré (1944) e Salesópolis (1913) que foram reestruturadas para receber visitantes interessados na temática energética, cultural e ambiental. Antes das doações à fundação, essas unidades haviam sido desativadas nas décadas de 1970 e 1980, por causas naturais devido às enchentes e/ou pela falta de interesse e investimentos na manutenção e operação. Essas usinas de pequeno porte eram consideradas pouco lucrativas em comparação às grandes unidades hidrelétricas que estavam sendo construídas.

Motivada a recuperar as atividades operacionais das usinas com a finalidade de atender à demanda energética local e obter recursos para o desenvolvimento das atividades culturais e ambientais, a Fundação Energia e Saneamento solicitou, em 1999, à Agência Nacional de Energia Elétrica (ANEEL) licença para a geração de energia por meio da reativação das quatro unidades. Os pedidos foram aprovados e duas usinas voltaram a operar em 2008: Corumbataí e Salesópolis, porém esta última teve uma tubulação rompida e seu funcionamento foi novamente paralisado seis anos depois, mas as atividades educacionais continuam no programa da usina.

Durante a década de 2000 a Usina de Corumbataí (Figura 18) manteve programas em colaboração com a UNESP de Rio Claro, para atividades educativas nas escolas da região sobre princípios do eletromagnetismo, utilizando maquetes e fazendo experimentos científicos; e ações de exploração (trilhas) e práticas de conservação do meio-ambiente. Estes programas tiveram boa aceitação, mas foram descontinuados pela Fundação Energia e Saneamento, notando-se atualmente a franca degradação das instalações de auditório e de experimentos, atualmente fechadas. (Relatório Técnico $5^{\mathrm{a}}$ expedição Projeto Eletromemória)

Se o conjunto das PCHs estivessem em operação, poderiam gerar, aproximadamente, 36 mil megawatts hora por ano (MWh/ano), suficientes para atender 15 mil residências com um consumo mensal de 200 quilowatts hora por mês ( $\mathrm{kWh} / \mathrm{mês}$ ). Além disso, a usina histórica em funcionamento valoriza o passado industrial deste setor, realça o potencial educativo, complementa a rede de transmissão e garante os recursos necessários para sua manutenção. 


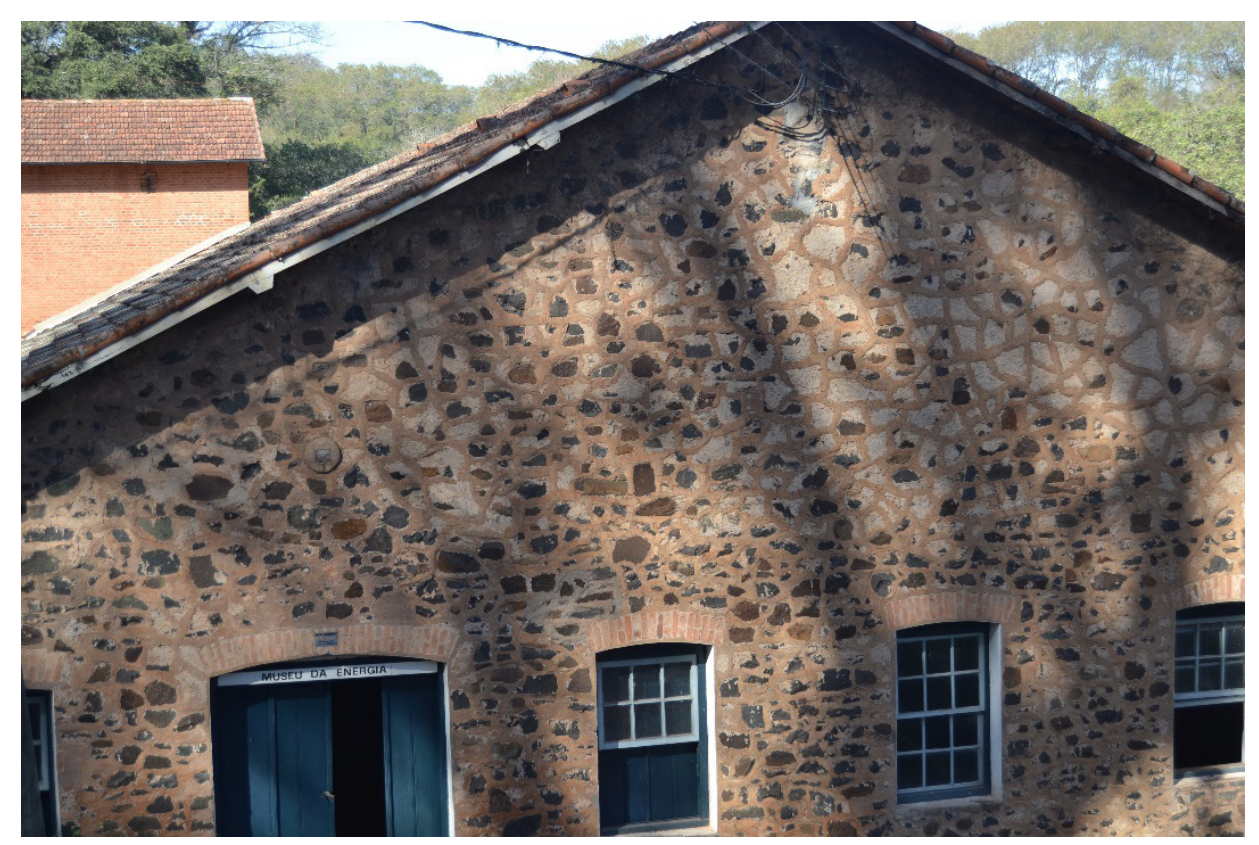

Figura 18 - Museu da Energia - Usina Corumbataí. Fotografia: Gildo Magalhães. Data: 21/07/2014. 


\section{Capítulo 3 - Café, Ferrovia e Eletricidade}

\section{O café}

Quando as primeiras pequenas centrais hidrelétricas foram construídas no Estado de São Paulo, a partir do final do século XIX, a economia paulista estava fortemente dependente do cultivo do café ${ }^{1}$. A expansão da cultura cafeeira se iniciou no Estado do Rio de Janeiro, em meados do século XVIII, e a produção em larga escala transformou esse produto em um dos principais recursos econômicos de exportação. Apesar deste fato é importante lembrar que tentativas de cultivo foram feitas em outros estados brasileiros como Pará ${ }^{2}$ e Maranhão e em virtude das condições ambientais não prosperou como no sudeste do Brasil.

Nas colinas dos mares de morros fluminenses do Planalto Atlântico o cultivo do café foi amplamente estabelecido, por volta do final do século XVIII, devido às condições naturais ideais de solos e climas promoviam o bom desenvolvimento do cultivo em larga escala (Figura 19). Dean (1994) em seu livro clássico “A Ferro e Fogo" descreve os fatores físicos ideais para o crescimento do café:

A planta encontrou na província do Rio de Janeiro um ambiente adequado, senão ideal, para o seu cultivo. Exige precipitação pesada de chuvas, de 1300 a $1800 \mathrm{~mm}$ por ano, porque transpira continuamente e, como uma árvore de sub-bosque, não tem nenhum mecanismo para armazenar ou conservar umidade. Submetida a uma estação seca em seu habitat nativo, retira umidade do solo a profundidades consideráveis - três metros ou mais - como reserva de água. O café foi a princípio plantado ao longo do litoral, onde pode ter sofrido um pouco com os ventos salinos oceânicos. Logo foi transferido para o planalto um pouco mais fresco, onde se dispõe de uma temperatura ótima de $20^{\circ}$ a $24^{\circ} \mathrm{C}$. A estação mais seca pronunciada do interior também é favorável porque o início das chuvas é o principal indutor da florescência e porque a floração promove o amadurecimento simultâneo dos frutos. A estação seca, de maio a agosto, quando se realiza a colheita, oferece outra vantagem competitiva, porque facilita a secagem dos grãos ao ar livre, um processo que, em outras circunstâncias, teria de ser realizado em fornos de lenha." (Dean,1994, p.195)

1 O café é uma planta de sub-bosque, originária dos planaltos da Etiópia, que se desenvolve em ambiente úmido e sombreado, porém com estação seca bem definida.

2 Estado onde possivelmente houve a segunda introdução desta espécie em 1727 segundo Dean (1994). 


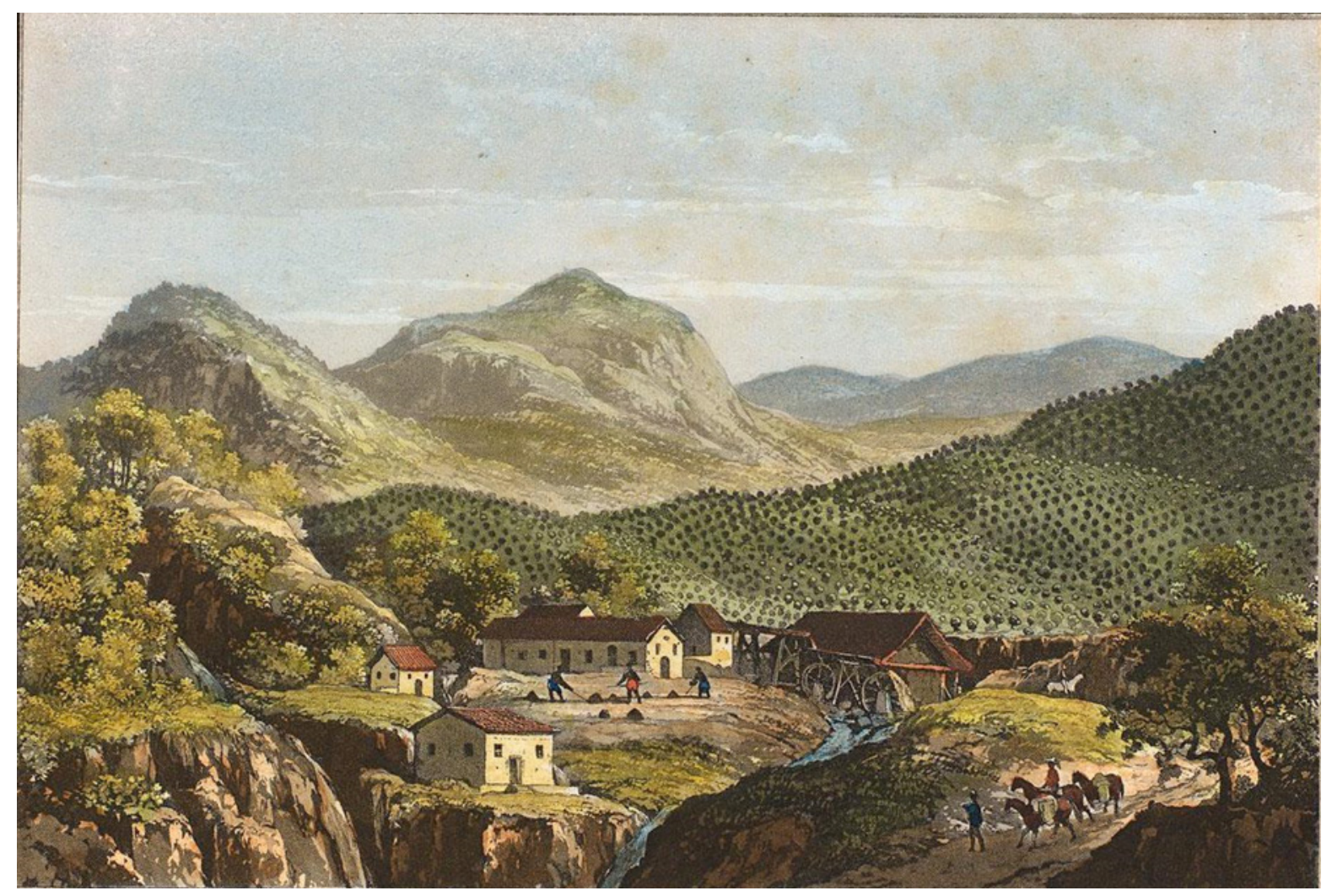

Figura 19. Plantação e café nas encostas do Rio de Janeiro. Gravura de Friedrich Salathé, sem data. Fonte: Arquivo digital da Biblioteca Nacional.

A boa produção cafeeira no Rio de Janeiro precisava expandir e novas frentes começavam a surgir no estado de São Paulo, em torno de 1790. O vale do Rio Paraíba foi a porta de entrada do café no território paulista e grandes fazendas surgiram nessa região, ocupando as encostas dos "mares de morros"3 do reverso da Serra do Mar e no sopé da Serra da Mantiqueira.

A floresta foi desalojada ${ }^{4}$ para o estabelecimento desta cultura, pois acreditava-se que a lavoura deveria ocorrer sobre solo recoberto por florestas, em condições ecológicas totalmente adversas do habitat original. Mas o desmatamento também oferecia outro recurso natural: a madeira para construção e carvão para os mercados, proporcionando bom retorno financeiro além do café. Essa região foi caracterizada por Monbeig (1984) como "primeira zona cafeicultora do Estado", mantendo boa produtividade até 1880.

Cabe destacar que a procura de condições bioclimáticas para a cultura do café levou a um intenso desmatamento no Estado de São Paulo, pois diversidade de tipologias florestais no estado de São Paulo responde a distintas combinações dos fatores físicos e a cultura do café se expandiu em função destas condições. Durante o período da economia do café, o conhecimento

3 Expressão utilizada por Aziz Ab' Saber para se referir à sucessão maciça de morros com formas de “meia-laranja”, arredondadas.

4 Expressão utilizada por Warren Dean (1994) 
empírico dos trabalhadores sobre os aspectos da natureza, em especial do repertório botânico como indicador de solos e clima, possibilitou "identificar fertilidades e adequações dos solos que serviam de suporte ecológico para determinados tipos de mata" (Ab' SABER, 2003, p. 50). As floradas permitiam aos observadores reconhecer empiricamente as espécies arbóreas indicadoras de áreas para a prática agrícola e, onde fosse constatada a presença do jacarandá (Jacaranda sp), peroba (Aspidosperma polyneuron), cedro (Cedrella fissilis), pau d' alho (Gallesia integrifolia), cabreúva (Myrocarpus frondosus), entre outras, significava terra boa para o cultivo; enquanto que outras espécies como palmeiras e árvores resinosas indicavam solos degradados. (DEAN, 1996; MOREIRA, 1873; SAMPAIO, 1890). Em raras ocasiões em que alguns exemplares nativos da Mata Atlântica eram poupados do corte, o pau d' alho permanecia como indicador de boa produtividade local aos potenciais interessados nas terras. Até os dias atuais essa árvore permanece como testemunho em muitas fazendas do interior de São Paulo. O efeito do desmatamento e da cultura do café sem considerar as curvas de nível levou a uma intensa degradação dos solos.

A prática de plantar cereais ou vegetais em linhas retas não era apenas um modo eficiente de aproveitar espaços escassos; também representava um meio agradável de impor a ordem humana ao mundo natural desordenado [...] Esmero, simetria e regularidade eram traços essenciais de uma boa agricultura e sempre foram a maneira caracteristicamente humana de indicar a separação entre cultura e natureza" (THOMAS, 1988. p. 304-305).

A expansão do café em São Paulo percorre um arco descrito por Monbeig (1984) como uma fronteira em movimento. Com o declínio do café no Vale do Paraíba a segunda região de expansão foi o arco "formado desde o município de Itu, ao sul, até o município de Mococa, ao norte, passando por Campinas, nos contrafortes ocidentais da Serra da Mantiqueira" (Monbeig, op.cit). Nessa região, a produtividade era maior. Campinas e Itu já não possuíam o mesmo dinamismo das cidades localizadas nos limites das franjas de café, enquanto que Mococa e Espírito Santo do Pinhal apresentavam expressiva produção. No início do século XIX, o viajante naturalista Auguste de Saint-Hillaire, em sua expedição pela província de São Paulo entre 1816 e 1822, descreve que a região também era muito apropriada ao cultivo de cana e nela existe um grande número de engenhos de açúcar, os quais enviam a produção para o Rio de Janeiro, via porto de Santos, e São Paulo.

A terceira e última região de expansão da cultura cafeeira compreendeu a depressão periférica paulista. Nestas algumas áreas apresentavam plantações isoladas entre Campinas e Botucatu enquanto que as maiores extensões de café estavam localizadas entre os municípios de Rio Claro e Batatais, ao norte, sendo fragmentadas principalmente por ferrovias ou cursos 
d'água. As vastas superfícies contínuas de cafezais desta fronteira, que coincide com o solo denominado "terra roxa", desenvolvido sobre basaltos, foram responsáveis pela superprodução entre os anos de 1900 e 1905, totalizando 110 milhões $^{5}$ de cafeeiros.

A grande demanda internacional e os altos lucros provenientes da produção tornaram o café o principal produto de exportação do Brasil (Figura 20), até ser abatida pela grande crise econômica mundial de 1929. Alguns poucos plantios se expandiram para o oeste do estado, mas a publicação do Decreto ${ }^{\circ}$ 22.121, de 22 de Novembro de 1932, em que foi proibido o plantio de novas lavouras no território nacional desanimou os produtores. Os altos impostos cobrados pelo governo, as condicionantes climáticas de secas e geadas ocorridas nos primeiros anos da década de 1940, além do esgotamento dos solos, levaram muitos fazendeiros a destruírem suas plantações.

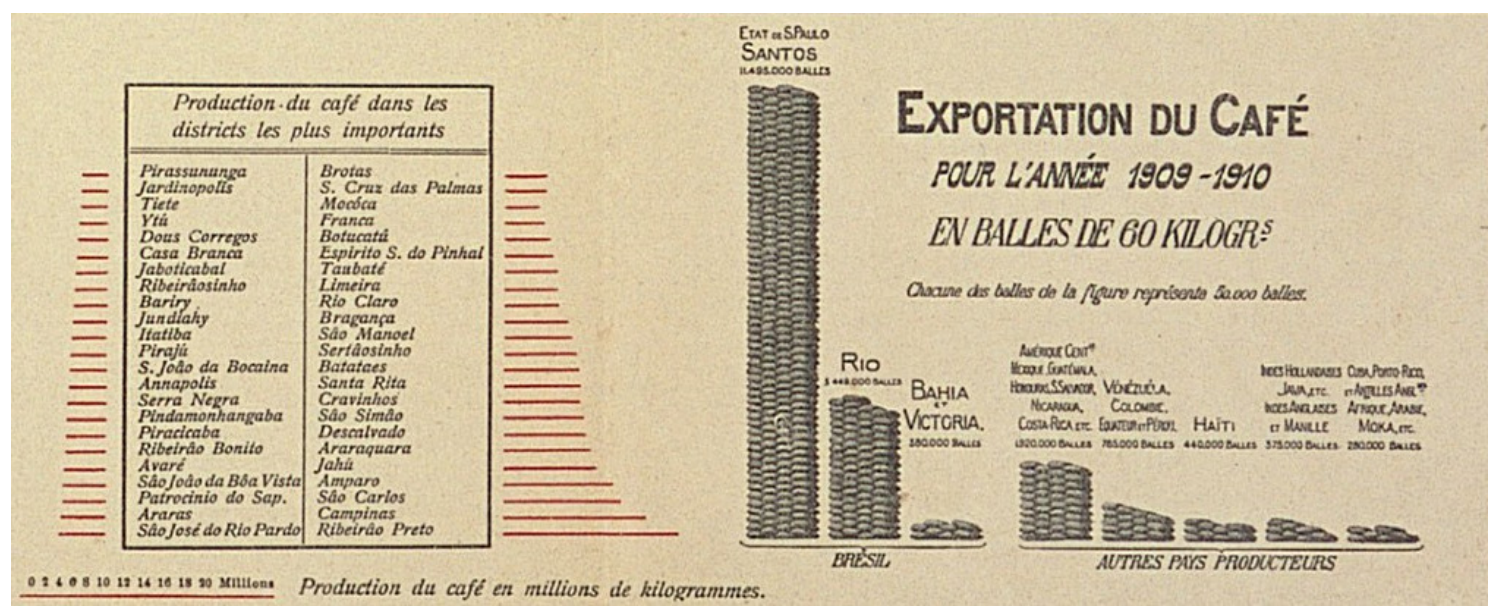

Figura 20. Informação extraída do mapa "Carta Geral do estado de São Paulo" elaborado pela CGG em 1910.

Todas as etapas de produção do café eram realizadas por negros escravizados nas duas primeiras regiões cafeicultoras e, após à abolição da escravatura em 1888, por imigrantes vindos de outras regiões do Brasil e de outros países. Esse processo foi facilitado pelo governo republicano que "pagou as passagens de imigrantes europeus dispostos a assinar contratos de trabalho com as plantações de café" (Dean, 1996), que garantiram altos rendimentos aos seus proprietários no sistema de colonato que se implantou na economica do café. Mais de um milhão de europeus aportaram no Brasil, entre italianos, espanhóis, portugueses, alemães e outros. Dados de população apresentados pelo $\mathrm{IBGE}^{6}$ indicam que o Estado de São Paulo apresentava, em 1890, 1.384.753 habitantes; em 1920 esse número saltou para 4.592 .188 habitantes, ou seja,

5 Monbeig, 1984.

6 IBGE, Directoria Geral de Estatística, [187?] / 1930, Recenseamento do Brazil 1872/1920; IBGE, Censo demográfico 1940/2010. Até 1991, dados extraídos de: Estatísticas do Século XX. Rio de Janeiro: IBGE, 2007 no Anuário Estatístico do Brasil 1994. Rio de Janeiro: IBGE, vol. 54, 1994. 
o aumento populacional foi mais de $330 \%$ para esse período e, em 1950 a contagem da população era de 9.134 .423 habitantes.

Os primeiros ensaios com o trabalho livre já haviam sido realizados em São Paulo em 1854, mediante o sistema de parceria e o contrato de colonos suíços e alemães [...] O sistema de parceria, embora não produzisse todos os resultados que seus promotores esperavam, contribuiu, contudo, para o estabelecimento e fixação dos primeiros colonos europeus, embora não contribuísse tanto para alterar o sistema de divisão da propriedade e nem para modificar os quadros de relacionamento em face da mão de obra escravizada predominante no país. (MATTOS, 1974, p. 40)

Mas o café não era a única cultura que proporcionava bom retorno econômico ao produtor. O mapa elaborado pela Comissão Geográfica e Geológica, em 1910, intitulado "Carte Générale de L'Etate de São Paulo” (Figura 21) apresenta, entre outras informações, as áreas de agricultura onde observa-se grandes extensões de cultivo do algodão, nas regiões de Sorocaba e Tatuí, que se expandiu para o oeste paulista nos anos posteriores onde surgiram as indústrias têxteis; o arroz amplamente cultivado no Vale do Rio Ribeira de Iguape e em algumas áreas do Vale do Paraíba; além de plantações de cana-de-açúcar na região de Piracicaba, litoral norte e Vale do Paraíba e diversas culturas no centro oeste do estado, entre eles o chá. 


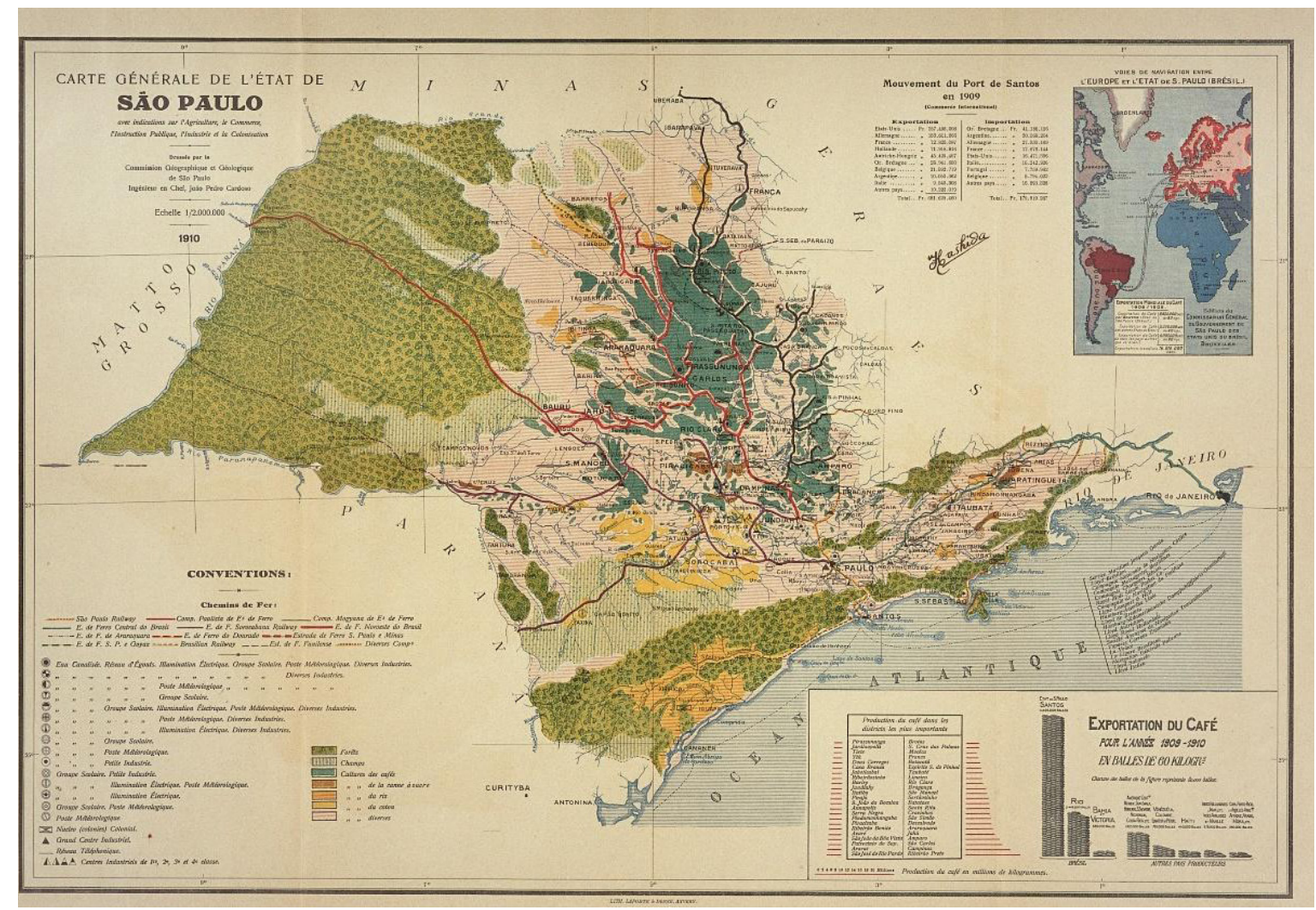

Figura 21. Mapa elaborado pela Comissão Geográfica e Geológica, em 1910, com a indicação da produção de café, algodão, arroz e outras culturas, além da cobertura vegetal remanescente no estado e infraestruturas de transportes e localização de indústrias.

Para escoar a produção agrícola para os principais centros consumidores utilizou-se a tração animal por caminhos já estabelecidos para o transporte, mas o tempo de viagem e a limitação no volume de carga eram entraves no desenvolvimento comercial e econômico de São Paulo. Portanto, havia necessidade de investimentos no transporte de carga e de passageiros mais eficaz para impulsionar os negócios, principalmente para o café, e assim as locomotivas entram em cena.

\section{As Ferrovias}

A primeira ferrovia paulista, a São Paulo Railway, começou a ser construída em 1860 com investimentos ingleses, tendo iniciado as atividades em 1867. Essa linha de $159 \mathrm{~km}$ e 11 estações $^{7}$ (Figura 22) conectou as cidades de Jundiaí, São Paulo e Santos, superando os 800 metros de desnível entre o planalto e o litoral e, por isso, tornou-se uma referência na engenharia ferroviária. A empresa obteve concessão de 90 anos para a exploração da linha, tornando-se o mais importante eixo ferroviário do Brasil, em termos de tráfego e rentabilidade, mesmo não tendo expandido seus trilhos para outras regiões do Estado. O longo de tempo de concessão e 7 Estações entre Jundiaí e Santos: Jundiaí, Belém, Perus, Água Branca, São Paulo, Braz, São Bernardo, Rio Grande, Alto da Serra, Raiz da Serra, Cubatão e Santos. 
o monopólio do único caminho ferroviário até Santos revelam o desinteresse na ampliação dos trilhos por essa companhia e, qualquer outra linha expandida para o interior viria ser sua tributária no sistema paulista. Isso favoreceu a organização de outras companhias ferroviárias. A partir dela, surgem, a Estrada de Ferro Sorocabana, ligando São Paulo a Ipanema; a Companhia Paulista de Estradas de Ferro, conectando Jundiaí a Campinas, ambas implementadas em 1872; a Companhia Mogyana de Estradas de Ferro e a Estrada de Ferro São Paulo-Rio, inauguradas em 1875; a Estrada de Ferro São Paulo-Minas em 1893; a Estrada de Ferro Araraquara em 1895; a Estrada de Ferro Noroeste do Brasil em 1904 entre outras. Esses eixos ferroviários, segundo Caio Prado Junior (1998) $)^{8}$ se assemelham "como uma vasta mão espalmada", ao observar os traçados nos mapas de São Paulo, caracterizada pela quase independência entre as vias devido à falta de articulação entre elas, exceto na capital.

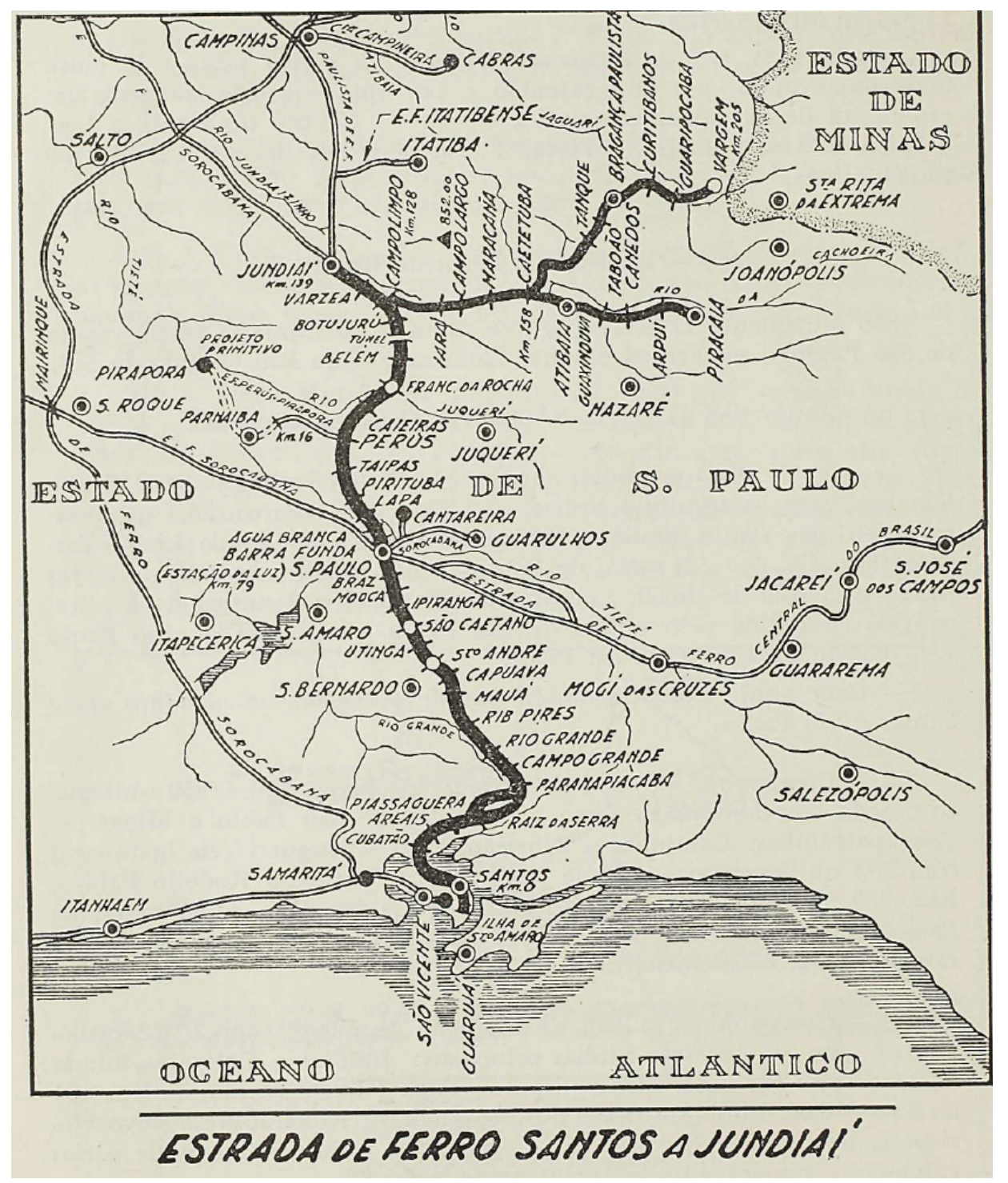

Figura 22. Mapa das linhas da São Paulo Railway. Fonte: IBGE, 1954.

8 Texto integrante do livro Evolução Política do Brasil e Outros Estudos de 1933.

9 Expressão utilizada por Teodoro Sampaio aos predecessores dessas vias na antiga capitania. 
Se o café foi decisivo no desenvolvimento ferroviário, este também foi importante para o desenvolvimento do café. A vinculação café-estrada de ferro vai começar a acentuar-se precisamente a partir de 1870 e a década de 1880-1890 é o período de maior desenvolvimento das ferrovias em São Paulo. (MATOS, 1974)

Investir no sistema de transporte ferroviário significava a possibilidade de aumento nos rendimentos e diversificação nos negócios, apesar dos altos custos de investimento e manutenção.

Das companhias ferroviárias existentes no Estado de São Paulo, "três se destacam pelo pioneirismo ferroviário, pela extensão das linhas e volume de transporte, e consequentemente pelo impacto no surgimento das cidades, das atividades econômica e tecnológica no interior do estado, as quais foram construídas na década de 1870-1880”. (Oliveira, 2012):

1. Companhia Paulista de Estradas de Ferro, popularmente conhecida como Paulista, que surgiu com os recursos financeiros da elite do café em 1868. A Paulista foi uma iniciativa do presidente da Província Saldanha Marinho. Essa empresa tinha o objetivo de prolongar em $45 \mathrm{~km}$ o trecho entre Jundiaí e Campinas, o que ocorreu em 1872, incentivado por garantia de juros ${ }^{10}$, pela zona privilegiada ${ }^{11}$ e pela desistência da São Paulo Railway em continuar sua expansão. Impulsionada pela intensidade da cultura cafeeira, sua expansão rumo ao interior paulista ocorreu posteriormente para Rio Claro, São Carlos, Barretos e Colômbia, até chegar no Rio Grande; mais tarde, Jaú, Bauru e Panorama, até o Rio Paraná. Também incorporou diversas ferrovias tributárias menores ao longo desses dois troncos principais, criando ampla rede ferroviária que atendia à região central do estado de São Paulo, destacando-se a E.F. Douradense e E.F. São Paulo-Goyaz. Operou em conjunto com outras ferrovias que partiam desde suas linhas tronco, como a Companhia Mogyana de Estradas de Ferro, em Campinas, e E.F. Noroeste do Brasil, em Bauru, que atuava no fluxo de passageiros e carga até a capital paulista e o porto de Santos. (GORNI, 2009). No final do século XIX, os trilhos se estendem por $823 \mathrm{~km} \mathrm{e}$ em meados do século XX totaliza $2.155 \mathrm{~km}$ de linhas férreas ( Quadro 7) com três tipos de bitola: $864 \mathrm{~km}$ com bitola de 1,60 m, $1.229 \mathrm{~km}$ com bitola de 1,00 m e $62 \mathrm{~km}$ com bitola de $0,60 \mathrm{~m}$.

10 A garantia de juros dava aos empresários a segurança de recuperar uma determinada margem do capital investido, mesmo que se revelasse menos rentável. As empresas deveriam reembolsar o dinheiro a mais que receberam do governo quando o negócio se mostrasse pujante, mas a única empresa a devolver a diferença dos juros foi a Companhia Paulista, em 1877. Fonte: http://revistapesquisa.fapesp.br/wp-content/uploads/2016/07/082-083_ Ferrovia_245.pdf?ce61d0

11 A região de Campinas prosperou muito com a cafeicultura e era conhecida na época como "capital agrícola". Houve investimentos em educação, indústria, centros de pesquisa, saúde, comércio e o transporte viria a contribuir no desenvolvimento urbano e cultural do interior paulista. 


\begin{tabular}{|l|l|l|l|l|l||l|l|}
\hline Ano & 1895 & 1901 & 1911 & 1920 & 1928 & 1942 & 1952 \\
\hline Extensão (km) & 991 & 1022 & 1.151 & 1.290 & 1.505 & 1.536 & 2.155 \\
\hline
\end{tabular}

Quadro 7. Evolução dos trilhos da Companhia Paulista de Estradas de Ferro entre 1901 e 1952. Fonte: Annuario Estatistico do Estado de São Paulo (1901, 1911, 1920, 1928 e 1942) e IBGE (1954). Org. Giorgia Limnios.

2. Companhia Sorocabana, fundada em 1870 por Luis Mateus Maylasky, ligado a um grande produtor de algodão da região de Sorocaba. O trecho inicial de $128 \mathrm{~km}$ foi inaugurado em 1875 e compreendia as cidades de Jundiaí e Sorocaba, passando por Itu, e depois foi ampliada até a antiga Real Fábrica de Ipanema para o transporte de ferro fundido, que seguia para o Rio de Janeiro passando por São Paulo. Com a incorporação da Estrada de Ferro Ituana em 1892 a nova empresa Companhia União Sorocabana e Ituana totalizava em 1899, $905 \mathrm{~km}$ de linhas. Em 1903 o governo federal assumiu o controle da empresa e entre 1907 e 1919 passa para o domínio da Brazil Railway Company, sendo renomeada para Sorocabana Railway Company. Retomada pelo Estado de São Paulo em 1919, passa a se chamar Estrada de Ferro Sorocabana e chegou a ter $2.171 \mathrm{~km}$ de linhas pelo interior paulista em 1952 (Quadro 8), todas de bitola de 1,00 m. (OLIVEIRA, 2012; MATOS, 1974). Uma importante realização dessa companhia foi a quebra do monopólio do acesso ao porto de Santos, dominada pela São Paulo Railway, com a construção do trecho entre Mairinque e Santos em 1937, possibilitando alcançar o mais importante porto brasileiro.

\begin{tabular}{|l|l|c|l|l|l|l|l|}
\hline Ano & 1895 & 1901 & 1911 & 1920 & 1928 & 1942 & 1952 \\
\hline Extensão (km) & 1.003 & - & 1.309 & 1.707 & 1.867 & 2.144 & 2.171 \\
\hline
\end{tabular}

Quadro 8. Evolução dos trilhos da Companhia Sorocabana entre 1901 e 1952. Fonte: Annuario Estatistico do Estado de São Paulo (1901, 1911, 1920, 1928 e 1942) e IBGE (1954). Org. Giorgia Limnios.

3. A terceira empresa ferroviária é a Companhia Mogyana. Foi fundada na cidade de Campinas em 1872 para expandir o trecho entre esta cidade e Mogi-Mirim. Assim como as demais, a construção foi patrocinada pelos barões de café da região que estabeleceram as suas linhas no sentido norte, até o Rio Grande, e no sentido do contraforte ocidental da Serra da Mantiqueira, adentrando no Estado de Minas Gerais, estabelecendo uma importante conexão férrea para além do território paulista. Nesse período essas eram as maiores áreas produtoras de café, juntamente com as novas áreas do noroeste do Estado. Essa companhia foi a que mais construiu ferrovias no decênio 1880-1890 no Estado de SP, além de ter empreendido linhas em Minas, como prolongamento de rede 
paulista, porém com ramais de menores extensões, com tamanho médio de 40km; denominadas como "cata-café”, já que serviam aos interesses das fazendas da região. "Direta ou indiretamente todo o triângulo mineiro e o Estado de Goiás, na cidade de Araguari, estavam articulados com as extensões da Mogyana, e outras companhias paulistas estenderam seus trilhos para os estados vizinhos, ao sul de Mato Grosso e norte do Paraná sendo esses caminhos os únicos elementos de ligação dessas região tão distantes dos principais centros de desenvolvimento do país, o que significou que as vinculações eram maiores com o Estado e São Paulo do que com seus próprios estados”. (Mattos, 1974)

\begin{tabular}{|l|l|l|l|l|l|l|l|}
\hline Ano & 1895 & 1901 & 1911 & 1920 & 1928 & 1942 & 1952 \\
\hline Extensão (km) & 1.071 & 925 & 1.201 & 1.521 & 1.513 & 1.963 & 1.959 \\
\hline
\end{tabular}

Quadro 9. Evolução dos trilhos da Companhia Mogiana entre 1901 e 1952. Fonte: Annuario Estatistico do Estado de São Paulo (1895, 1901, 1911, 1920, 1928 e 1942) e IBGE (1954). Org. Giorgia Limnios.

Como dito anteriormente (página 79), a expansão do café no Estado de São Paulo ocorreu a partir do Vale do Paraíba e com a ampliação da linha férrea do Rio de Janeiro até a cidade de Cachoeira/SP, que veio a ser a Estrada de Ferro Central do Brasil. Para conectá-la à capital paulista foi construída uma ligação, a partir de São Paulo, por caminhos bastante conhecidos pelos barões do café da região, nas proximidades do Rio Paraíba do Sul, passando pelas cidades de Mogi das Cruzes, Jacareí, São José dos Campos, Caçapava, Taubaté, Pindamonhangaba, Guaratinguetá e Lorena até estabelecer a ligação em Cachoeira no ano de 1877. O inconveniente era a diferença da bitola dos trechos conectados; em terras paulistas, era bitola estreita e em terras fluminenses, bitola larga, que exigia a baldeação para seguir viagem.

Tecnicamente, as empresas ferroviárias construíram as linhas com três tipos de bitolas, a Paulista optou por utilizar a bitola larga $(1,60 \mathrm{~m})$ no tronco principal, a mesma utilizada pela São Paulo Railway, o que proporcionou fluidez no deslocamento, possibilidade de transportar maior quantidade de cargas e maior velocidade das locomotivas, apesar do custo mais alto. As demais optaram pela bitola de 1,00 m e 0,60 m, e isso implicava, necessariamente, na mudança de locomotivas para a continuidade dos percursos.

Os caminhos ferroviários tornaram-se os principais vetores de ocupação no estado, além de servirem como transporte, produziam cidades e agrupavam indústrias. Os terrenos lindeiros aos trilhos eram mais baratos e isso criava condições para a instalação de infraestruturas fabris, grandes armazéns para café, cereais e outros produtos agrícolas, depósitos de combustíveis e oficinas. As estações ferroviárias eram estabelecidas, em média, a cada $13 \mathrm{~km}$, seja como ponto de abastecimento de água ou lenha, por cruzamento de linhas ou para atender a localidade, convertendo-se em um ponto agregador de pessoas, mercadorias e serviços, determinando, muitas 
vezes o desenvolvimento de cidades; no período de maior expansão ferroviária (1872 -1941) o total de municípios paulistas saltou de 89 para $270^{12}$.

Essa centralidade gerada pelas estações significou o surgimento de hotéis, pensões, barracões de armazenagem, fábricas, bairros dos funcionários da companhia e, invariavelmente um bem cuidado jardim público, como cartão de apresentação aos viajantes. Apareceram, ao seu lado, também as primeiras iniciativas de integração dos transportes, com pontos de carros de aluguel (charretes em sua maioria) e linhas de bondes, mesmo que ainda de tração animal. (NOGUEIRA; ARGOLLO FERRÃO, 2015, p.21)

Duas companhias ferroviárias vincularam o sistema ferroviário ao sistema de navegação fluvial, criando um sistema misto de transportes. Foi o caso da Sorocabana e Ituana que aproveitaram $238 \mathrm{~km}$ das águas dos rios Tietê e Piracicaba e a Cia. Paulista que utilizou o potencial dos rios Mogi-Guaçu e Pardo, inclusive essa empresa, em um certo momento, foi denominada Companhia Paulista de Vias Férreas e Fluviais. Porém, o baixo interesse no desenvolvimento desse sistema de transporte e os esforços voltados quase que totalmente para as ferrovias, implicou no abandono da navegação fluvial (MATOS, 1974).

A adoção de tecnologias no sistema ferroviário brasileiro tem como principais referências as inovações aplicadas nas ferrovias europeias e americanas. A discussão sobre a eletrificação ferroviária foi assunto em 1915, no Clube de Engenharia do Rio de Janeiro, quando Artur de Miranda Ribeiro apresentou estudos ${ }^{13}$ publicados na revista Techique Moderne que envolvem o uso da tração elétrica nas locomotivas, conforme consta no livro Energia Elétrica em Questão Debates no Clube de Engenharia (GORNI, 2009).

1. A eletrificação das grandes linhas de estrada de ferro deve ser estudada individualmente, de acordo com os elementos fornecidos por caso isolado, tendo-se em vista não só o caráter militar e estratégico da linha, como também suas características de ordem econômica e técnica;

2. A eletrificação das linhas na Estrada de Ferro Central do Brasil deve abranger somente as que servem os subúrbios e a serra, até a estação de Barra do Piraí;

3. A eletrificação é sempre vantajosa para as explorações a curta e a média distâncias;

4. O estabelecimento da tração elétrica é muito mais dispendioso que o

12 IBGE, Evolução da Divisão territorial do Brasil 1872-2010. Rio de Janeiro, 2011.

$13 \mathrm{O}$ engenheiro francês Hippolyte Parodi implementou a eletrificação das ferrovias francesas. 
estabelecimento de tração a vapor;

5. Sob o ponto de vista econômico, a tração elétrica para as linhas de tráfego intenso exige grandes prazos para a exploração das concessões;

6. A locomotiva elétrica está naturalmente indicada toda vez que se necessitar de maior velocidade e maior tonelagem rebocada;

7. Nas linhas de forte rampa ou de montanha, o emprego de locomotiva elétrica não sofre mais contestação lógica de qualquer espécie ou natureza;

8. Na viação urbana, suburbana e nas linhas de interesse local, a adoção de unidades simples é mais vantajosa do ponto de vista técnico-econômico;

9. A tração elétrica é sempre recomendável nas linhas de montanha e de tráfego contínuo.

No Brasil, o uso da eletricidade no transporte ferroviário teve início nas linhas de bondes do Rio de Janeiro e São Paulo linhas em substituição à tração animal no início do século XX. Para implementar a eletrificação ferroviária foi necessário interligar os trilhos à rede geral de eletricidade, o que exigiu grandes instalações fixas de redes de alimentação, subestações, catenária ou terceira linha férrea, além de grandes investimentos financeiros (PICARD, 1997).

A eletrificação das ferrovias no Estado de São Paulo, se iniciou em 1922 pela Cia Paulista de Estradas de Ferro, no trecho entre Jundiaí e Campinas, como uma alternativa à energia gerada à vapor, cada vez mais difícil de obter de forma abundante e barata para atender ao crescente tráfego de suas linhas, o que exigiu a compra de locomotivas pela General Eletric e Westinghouse para se adequar ao sistema elétrico ferroviário. O rápido retorno dos investimentos após a adoção do sistema elétrico para a linha em questão, motivou a continuidade no projeto para outros trechos (Quadro 10), totalizando 20,9 \% de linhas eletrificadas entre 1922 e 1948. Cabe ressaltar que uma viagem experimental com trem de tração elétrica ocorreu em 1921 entre as estações Jundiaí e Louveira. A companhia não dispunha de usina própria para obtenção de energia, sendo adquirida pela São Paulo Tramway Light and Power Co. Ltd. com subestação conversora localizada na cidade de Louveira.

\begin{tabular}{|c|c|c|c|}
\hline Trecho & $\begin{array}{c}\text { Extensão total } \\
\mathbf{( K m )}\end{array}$ & $\begin{array}{c}\text { Extensão eletrificada } \\
\mathbf{( K m )}\end{array}$ & $\begin{array}{c}\text { Data da Inaugura- } \\
\text { ção }\end{array}$ \\
\hline Jundiaí-Campinas & 44,04 & 44,04 & 1922 \\
\hline
\end{tabular}




\begin{tabular}{|c|c|c|c|}
\hline Campinas - Tatu & 93,79 & 49,75 & 1925 \\
\hline Tatu - Rio Claro & 133,84 & 40,04 & 1926 \\
\hline $\begin{array}{c}\text { Rio Claro - São } \\
\text { Carlos }\end{array}$ & 206,38 & 72,46 & 1928 \\
\hline São Carlos - Rincão & 285,75 & 79,45 & 1928 \\
\hline Itirapina - Jaú & 387,17 & 101,41 & 1941 \\
\hline Jaú - Bauru & 452,14 & 64,97 & 1948 \\
\hline
\end{tabular}

Quadro 10. Trechos eletrificados pela Cia. Paulista de Estradas de Ferro no Estado de São Paulo. Fonte: IBGE, 1954.

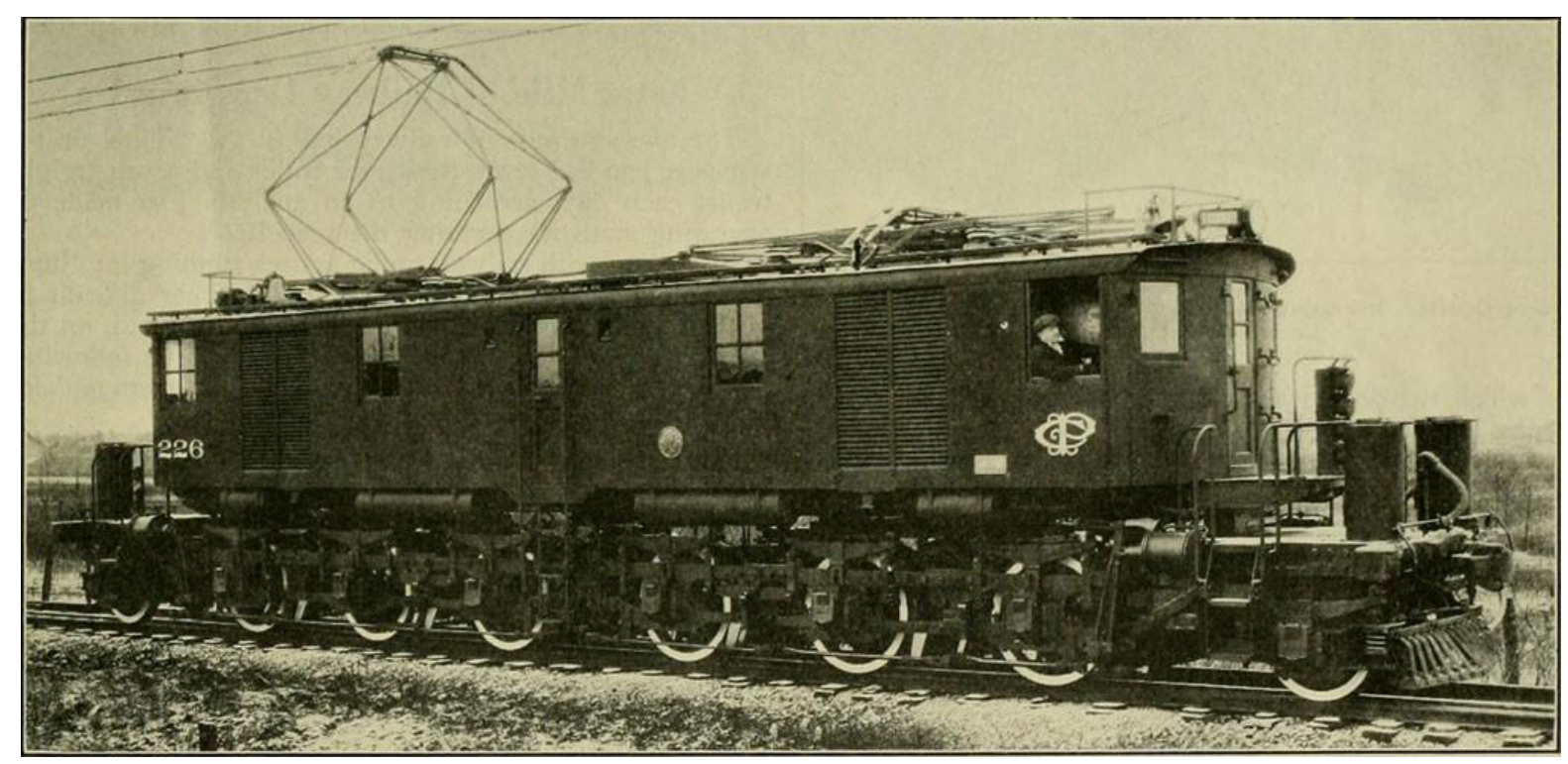

Foto 23. Locomotiva elétrica no 226 da Companhia Paulista - General Electric - década de 1920 (Foto de Railway and locomotive engineering: a practical journal of railway motive power and rolling stock. New York: A. Sinclair Co, 1928.). Fonte: http://museusferroviarios.net.br/antigas-companhias/companhia-paulista/. Acesso em 10/05/2018.

A Estrada de Ferro Sorocabana implementou a eletrificação em 1944, devido às dificuldades em conseguir combustível necessário para a movimentação dos trens, em virtude do baixo poder calorifico do carvão nacional, elevado custo do carvão estrangeiro e insuficiência de lenha. Inicialmente, foi favorecido o trecho de $63 \mathrm{~km}$ entre as cidades de Sorocaba e Amador Bueno e, no ano seguinte, a companhia finalizou essa inovação alcançando a cidade de Iperó, totalizando 139,43 km de linhas elétricas. Como a produção de energia elétrica era abundante e os preços vantajosos, a companhia decidiu adquirir da empresa Light and Power o suprimento necessário para expansão de suas linhas eletrificadas, conforme Quadro 11. As linhas eletrificadas dessa empresa correspondiam a $16,82 \%$ do total da rede. 


\begin{tabular}{|c|c|c|c|}
\hline Trecho & $\begin{array}{c}\text { Extensão total } \\
\mathbf{( K m )}\end{array}$ & $\begin{array}{c}\text { Extensão eletrificada } \\
(\mathbf{K m})\end{array}$ & $\begin{array}{c}\text { Data da Inaugu- } \\
\text { ração }\end{array}$ \\
\hline São Paulo - Sorocaba & 104,34 & 104,34 & 1944 \\
\hline Sorocaba - Iperó & 139,47 & 35,13 & 1945 \\
\hline Iperó - Laranjal Paulista & 186,33 & 46,86 & 1947 \\
\hline $\begin{array}{c}\text { Laranjal Paulista - Ju- } \\
\text { quiratiba }\end{array}$ & 217,20 & 30,86 & 1949 \\
\hline Iperó - Tatuí & 235,77 & 18,57 & 1950 \\
\hline Tauí - Itapetininga & 278,60 & 42,83 & 1951 \\
\hline Juquiratiba - Botucatu & 329,31 & 50,70 & 1951 \\
\hline Botucatu - R. Junior & 335,08 & 5,77 & 1952 \\
\hline R. Junior - Pátio 3 & 365,29 & 30,21 & 1953 \\
\hline Q
\end{tabular}

Quadro 11 - Trechos eletrificados pela Estr. de Ferro Sorocabana no estado de São Paulo. Fonte: IBGE, 1954.

Apesar dos dados positivos ${ }^{14}$, em termos econômicos, decorrentes da implantação da rede elétrica no sistema ferroviário, nem todas as linhas foram eletrificadas e os motivos se devem ao alto custo para adequação do sistema à rede elétrica; algumas falhas na transmissão de energia, que provocava a paralização dos trens; e o uso de motores à óleo diesel. Além disso, as políticas favoráveis ao rodoviarismo no Brasil, acentuado a partir da década 1950, desanimou as companhias a promoverem modernizações e investimentos de suas estruturas, tornando-as obsoletas nos anos seguintes, a ponto de algumas estruturas desaparecerem da paisagem como os trilhos, locomotivas e oficinas. Algumas estações resistiram ao tempo e foram convertidas em museus, bibliotecas ou tiveram outros usos. (MATOS, 1974; IBGE, 1954)

\section{As primeiras usinas hidrelétricas paulistas}

A instalação dos empreendimentos hidrelétricos sempre exige grandes conhecimentos da paisagem e sua dinâmica, mas as geografias do território paulista necessita de dados especializados e sofisticados para a concretização do desenvolvimento industrial.

Os primeiros empreendimentos hidrelétricos estão associados a eletrificação urbana das cidades nos territórios cafeicultores. Os cafeicultores paulistas vislumbravam um território industrial, mais moderno e avançado em termos tecnológicos. Já possuíam investimentos nos transportes e nas indústrias têxteis, a energia elétrica por fontes térmicas era um fato, mas ao que parece pretendiam melhorar a infraestrutura.

Importantes estudos geográficos dos rios de São Paulo foram conduzidos por equipes de 14 Dados econômicos publicados no I Centenario das Ferrovias Brasileiras 
engenheiros da Comissão Geográfica e Geológica (CGG) a partir do 1886. Inicialmente, foram realizadas expedições no curso dos rios Itapetininga e Paranapanema, até a foz no Rio Paraná. A pedido do então presidente da província de São Paulo Conselheiro João Alfredo Correa de Oliveira, a recém-formada Comissão, era chefiada por Orville Adelbert Derby e seu primeiro ajudante era o engenheiro Theodoro Fernandes Sampaio, cujo objetivo foi o levantamento de dados climatológicos, geológicos, pedológicos, hidrográficos, botânicos, sociais, agrícolas, cartográficos, etc. A caracterização dos cursos d' água abrangeu informações sobre a largura e comprimento, condições de navegabilidade, vazão, velocidade, altimetria, toponímias, morfologias, etc. registrados em relatórios, mapas (Figuras 24 e 25) e fotografias. Outras importantes expedições foram realizadas nos rios Feio e Aguapeí, em 1905, e também no Rio Grande e seus afluentes, em 1910. Para auxiliar os levantamentos de campo, os engenheiros utilizaram os poucos mapas existentes do território de SP, mas os levantamentos realizados pelas companhias ferroviárias foram de bastante valia para as equipes da CGG.

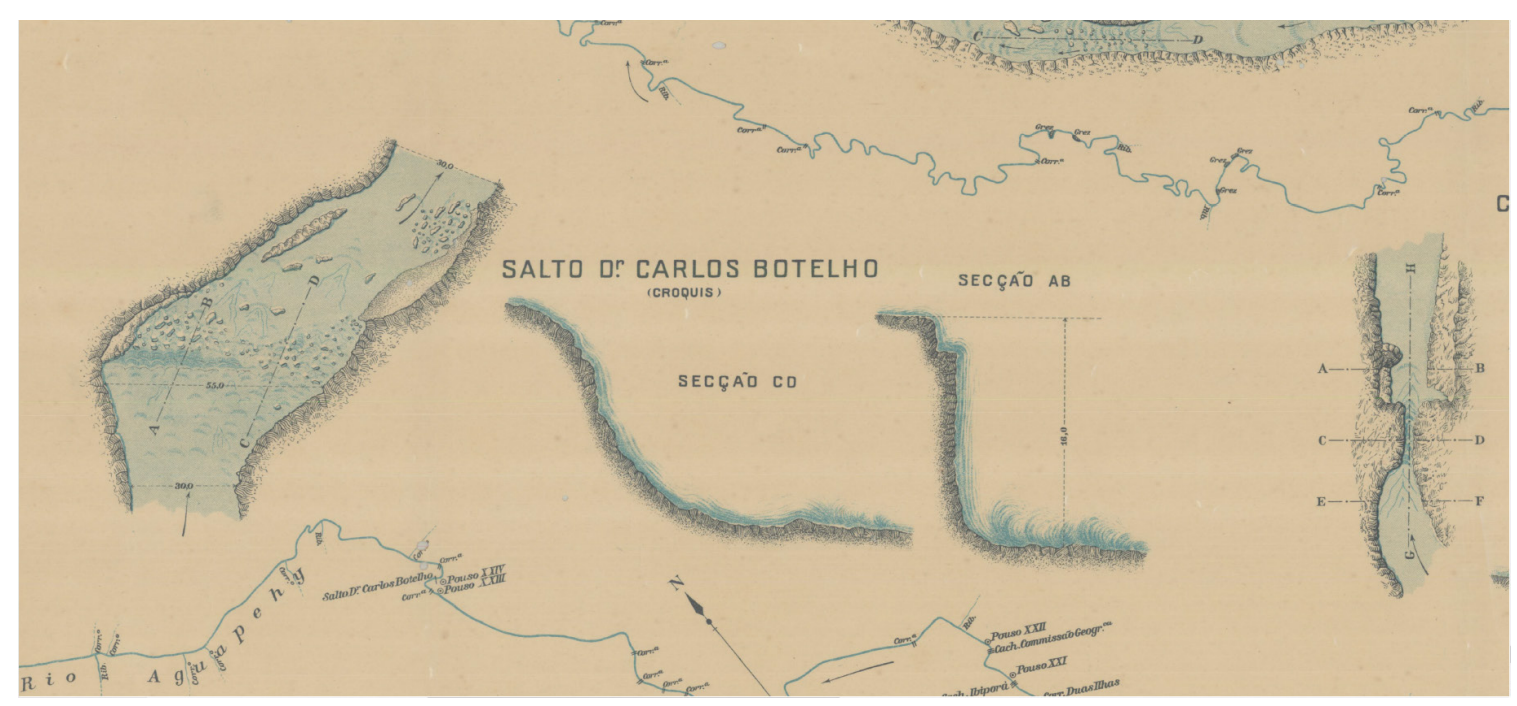

Figura 24. Trecho da planta Rio Aguapehy, escala 1:50.000, elaborado pela CGG, 1906.

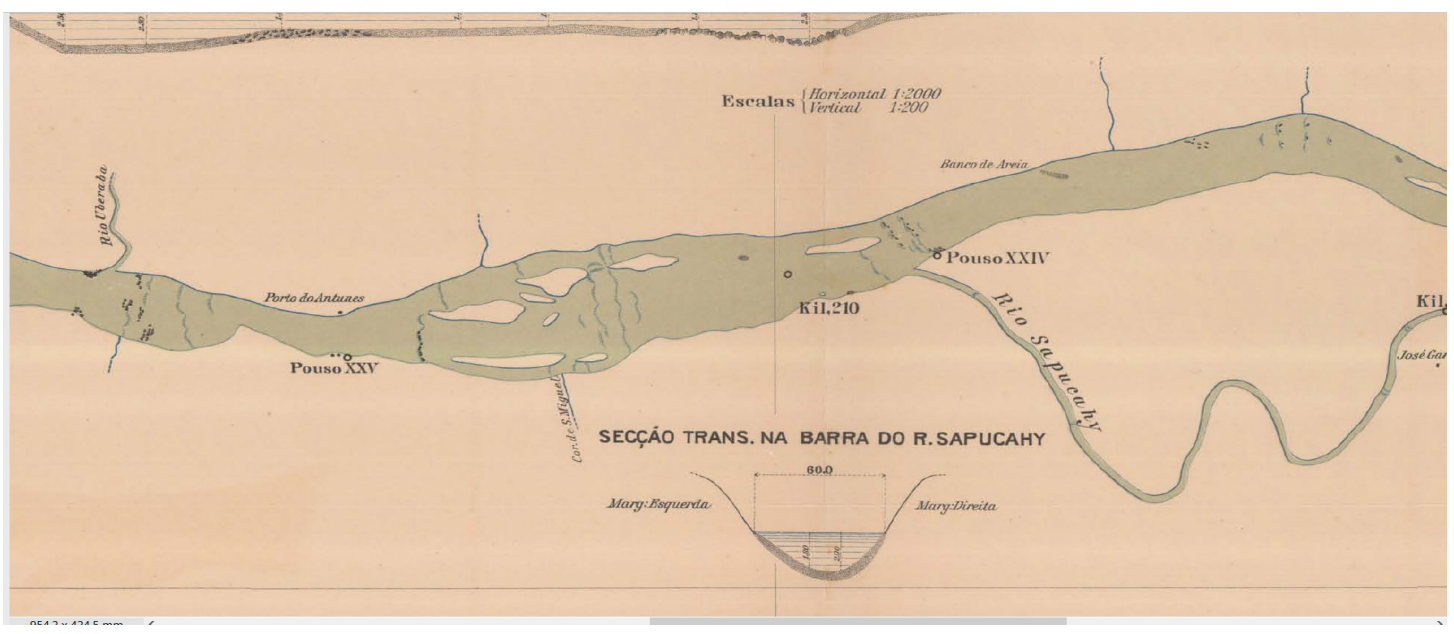

Figura 25. Trecho da planta Rio Grande, escala 1:50.000, elaborado pela CGG, 1910. 
No relatório da expedição do Rio Grande e seus afluentes, de 1913, os engenheiros Guilherme Wendel e Arthur Horta O'Leary descrevem que o futuro deste rio não está na navegabilidade, apesar do potencial, e sim na "força hydraulica colossal, armazenada nas suas águas". Em outro trecho do relatório, o chefe da Comissão João Pedro Cardoso deixa claro os objetivos da missão geográfica:

É tempo de deixarmos de olhar só para o lado do Oceano e voltarmos nossas vidas para o centro do país, estudando o aproveitamento das quedas d' água, já para a utilização de força e luz, já para forçar a produção de certas regiões fazendo-se a irrigação em alta escala...

Ao se referir à cachoeira do Marimbondo e o Salto dos Patos o chefe reforça a potencialidade hidrelétrica desses locais e em quais atividades a energia poderia ser empregada:

Creio que eles representam uma reserva explendida que temos guardada para o futuro, pois, não possuindo carvão de pedra, teremos que ir procurar na hulha a força para eletrificar as nossas estradas de ferro e desenvolver as nossas industrias; por isso mandamos fazer um levantamento bem detalhado dessa região na sua escala 1:2.000, afim de torna-la conhecida.

Wendel, em artigo publicado na Revista Polythechnica ${ }^{15}$ de 1907 trata das potencialidades hidráulicas dos rios paulistas, principalmente dos rios estudados pela CGG, e cita como exemplo, as grandes usinas hidrelétricas construídas na Noruega ${ }^{16}$ e nos Estados Unidos, pois estes eram os modelos hidrelétricos vislumbrados para a concretização do desenvolvimento industrial em São Paulo. Na engenharia, a execução de grandes projetos hidrelétricos, ao estilo americano, era totalmente possível em termos hidrográficos, visto que os dados ${ }^{17}$ relativos à vazão d'água dos saltos de Itapura e Urubupungá, no Rio Grande, foram comparados aos das Cataratas do Niágara, apresentando valores equivalentes de 6 milhões de litros por segundo.

O emprego da energia elétrica no Estado de São Paulo ocorreu ainda no século XIX, principalmente por iniciativa privada, para atender a iluminação pública (ruas, praças e estações ferroviárias) de algumas cidades, como forma de melhoramento urbano, ou para fornecimento de energia nas atividades industriais. Inicialmente a energia era fornecida por centrais térmicas e, em seguida, foram combinadas ou substituídas pelas usinas hidrelétricas, que só foi possível 15 Vol. 3, nº 15, pág. 140-146 de 1907.

16 Provavelmente o autor se referiu à usina Rjukan-Notodden, de 1901, correspondente a um complexo industrial que compreende centrais hidrelétrica, ferrovias, fábricas, redes de transporte e núcleos urbanos. Foi declarado Patrimônio Industrial pela UNESCO em 2015.

17 A comparação da vazão foi apresentada por Francisco Ferreira Ramos na Revista Polytechnica, São Paulo, v. 2, n. 9, p. 107-111, dez. 1905. 
em consequência do grande avanço técnico-científico de geração e transmissão de energia. "A grosso modo um gerador térmico ou hidráulico só se diferem pela presença ou não da caldeira; o maquinário e seu funcionamento é praticamente o mesmo" (Mortatti, 2000).

As usinas hidrelétricas devem ser consideradas como um sistema para compreender seu funcionamento. Há o componente físico, que envolve a bacia hidrográfica; o componente relacionado à infraestrutura técnico e mecânica, adaptado ao suporte natural, e o componente geração-transmissão e setor consumidor (STERNBERG, 1990).

No que se refere às características físicas para a instalação de hidrelétricas, o território paulista apresenta uma "combinação de fatos climáticos, morfológicos, estruturais e hidrográficos" favoráveis para o aproveitamento energético em quase todas as regiões (Ab'Saber, 2004, p. 87). O autor estabeleceu sete agrupamentos de situações topográficas e hidrográficas que favoreceram a instalação de centrais hidrelétricas:

1. "Cabeceiras dos rios nascidos no reverso continental da Serra do Mar, com reversão das águas para as grandes escarpas atlânticas;

2. Área de fall line ("linha de quedas") e de fall zone ("zona de quedas"), de tipo apalachiano ${ }^{18}$, situadas entre os terrenos cristalinos do Planalto Atlântico e os primeiros terrenos sedimentares da Depressão Periférica;

3. Áreas de cachoeiras de diabásio ${ }^{19}$, postas a aflorar na Depressão Periférica;

4. Areas de percées $^{20}$ consequentes dos rios paulistas, frente às escarpas arenítico-basálticas;

5. Áreas das sucessivas e grandes quedas basálticas do Planalto Ocidental;

6. Áreas dos pequenos maciços mamelonizados e de meandros encaixados, existentes nas regiões serranas acidentadas da Bacia do Paraíba do Sul;

7. Alguns cursos d'água da Serra do Mar, no Médio e Alto Ribeira e seus afluentes".

Em seus estudos, Ab'Saber considera que pode-se distinguir dois principais agrupa-

18 Enquadramento em função da direção dos rios e falhamentos.

19 Rocha eruptiva intrusiva de coloração preta ou esverdeada. Distingue-se dos basaltos por causa de sua textura.

20 Refere-se ao fluxo segundo o declive do terreno. 
mentos que diferenciam a rede hidrográfica paulista: no Planalto Atlântico (Serra do Mar e Serra da Mantiqueira) onde grande parte dos cursos d' água se caracterizam por suas pequenas dimensões, tanto na extensão quanto no volume em terrenos de grande diferença altitudinal, apresentando sucessivos saltos de fluxos rápidos "constituindo um verdadeiro alinhamento de pequenos rios encachoeirados na paisagem". A rede hidrográfica do Planalto Ocidental apresenta traços bem distintos como grandes cursos d' água se estendendo por centenas de quilômetros em uma paisagem de baixa variação altimétrica, com grande poder de entalhamento na bacia sedimentar do Paraná, constituída de diversas formações geológicas, originando quedas substanciais e/ou uma série saltos em determinados pontos do curso dos rios, revelando muitas vezes os derrames basálticos nos leitos fluviais; indicativos de uma condição natural favorável à instalação das usinas, tão procurados nos primórdios hidrelétricos (Ab’Saber, 1954).

A geração de energia hidrelétrica a partir dos demais componentes do sistema foi produzida por um significativo conhecimento da engenharia civil na construção de barragens, canais de adução, casa de máquinas e também da engenharia elétrica que produziu geradores e linhas de transmissão (Magalhães, 2000, p. 36).

As características dos empreendimentos hidrelétricos estão relacionadas à morfologia e hidrografia do local. A vazão e a altura da queda d' água dependem dos fatores hidrográficos, topográficos e geológicos da bacia que, por sua vez, definem a capacidade energética da usina, bem como o tipo de turbina mais adequada para a conversão da energia hidráulica em elétrica, os tipos de barragens e dimensões do reservatório. Quando há necessidade de acumulação de água para a operação da usina, as barragens e reservatórios localizam-se nos níveis mais altos, próximos às cabeceiras de drenagem, de forma a aproveitar o potencial hidráulico da queda d' água. Se o rio oferecer condições de vazão suficiente para o aproveitamento direto de seu fluxo, ou seja, sem a necessidade de acumulação, as usinas podem operar a fio d'água. A casa de máquinas sempre está localizada no nível mais baixo terreno, pois as águas que chegam nas turbinas, pelos canais de adução e/ou condutos forçados, voltam rio pelo canal de fuga. A paisagem e seus recursos foram determinantes para a instalação do sistema hidrelétrico, e à engenharia coube a função de adaptar cada componente ao quadro paisagístico, nos locais mais apropriados para suas finalidades, para melhor aproveitamento da força das águas.

A rapidez na disseminação dos usos da energia elétrica, ainda no início da eletrificação, está associada à duas qualidades essenciais: à transmissibilidade, pelo alcance da energia a grandes distâncias e com pequenas perdas e, à flexibilidade, pela possibilidade de converter eletricidade, de forma fácil e eficiente, em outras formas de energia como luz e calor. (Cabral et. Al., 1988, p.17).

As cidades de ocupação mais antiga do interior paulista, principalmente aquelas surgidas pelo advento da agricultura do algodão e café, foram as primeiras a se beneficiarem pela construção de hidrelétricas, pois além das condições hidrográficas propícias, algumas possuíam 
infraestruturas fabris e/ou ferroviárias que optaram por essa fonte energética para modernizar e ampliar a capacidade produtiva.

"Até o século XX, a produção e distribuição de energia circunscreviam-se aos centros urbanos [...] pois as possibilidades técnicas de transmissão eram restritas ao lugar" (SANTOS, 2001, p.37). O surgimento e desenvolvimento das cidades sempre estiveram condicionadas à dependência dos recursos hídricos. A localização das fábricas nas proximidades dos rios foi um facilitador para que algumas delas implantassem seu próprio sistema hidrelétrico, como é o caso da Usina Luiz de Queiroz em Piracicaba, construída no Rio Piracicaba para atender a fábrica de tecidos em 1893. As potencialidades hidrelétricas do Rio Tietê, nos municípios de Itu e Salto, favoreceram a construção de diversos empreendimentos têxteis e, a eles associados, foram implantadas em 1901 as usinas Jupter (fábrica José Galvão) e Fortuna (fábrica Barros Júnior); e posteriormente a usina Porto Góes, concluída pela Brasital em 1923. Concomitante à construção das fábricas e usinas, a cidade se beneficiava com o surgimento de praças, pontes, acessos, iluminação pública e residências nas suas proximidades.

O aperfeiçoamento na transmissão de energia, por meio da expansão da rede e maior capacidade de atendimento ao consumidor, "contribui para uma reorganização das oportunidades locacionais, especialmente para as indústrias e sistemas de transporte" que puderam se estabelecer em locais mais afastados e privilegiados, tornando-os espacialmente independentes (STERNBERG, 1990).

Nesse sentido, as atividades industriais se espalham para outros locais considerando, prioritariamente, a proximidade com as estações ferroviárias; e os locais onde havia oferta de energia, o que acontecia perto da linha de transmissão. (Mortatti, 2013). Atualmente, os eixos rodoviários são os principais vetores de ocupação industrial. Essas preferências se devem às possibilidades de escoamento da produção, de deslocamento e terrenos mais baratos.

Essa nova perspectiva geográfica dos usos dos espaços, desencadeada pela industrialização, significou uma nova ordem produtiva e social estabelecidas pelas

relações entre empresas do mesmo setor, entre empresas de diferentes setores, entre centros de produção e centros populacionais e centros de produção e o ambiente natural. O resultado deste processo é a configuração de paisagens industriais formadas principalmente por centros de produção, habitação, centros sociais, vias de comunicação e infraestruturas de serviços, que fazem parte da identidade do território. A paisagem industrial como paisagem cultural é de vital importância para entender o que foi a industrialização. (Areces, 2010, p.94)

A implantação gradual das pequenas centrais hidrelétricas no território paulista entre 1880 e 1940 é caracterizada, por Lorenzo (1994/1995), a partir de três períodos: o primeiro 
corresponde à implantação de hidrelétricas e introdução da energia elétrica nas atividades industriais, o segundo período refere-se ao aumento da capacidade de produção de eletricidade e o uso cada vez maior no setor industrial, e o terceiro período é marcado por transformações ocorridas após a grande crise mundial de 1929. Esses períodos indicam diferentes momentos

\begin{tabular}{|c|c|c|}
\hline \multicolumn{3}{|c|}{ Pequena Central Hidrelétrica Salto de Pinhal } \\
\hline $\begin{array}{l}\text { Município: Espirito } \\
\text { Santo do Pinhal }\end{array}$ & Temática: Patrimônio Industrial/Paisagístico & Data: 1911 \\
\hline $\begin{array}{l}\text { Situação: } \\
\text { Desativada desde } \\
1994\end{array}$ & Curso d' água: Rio Mogi-Guaçu & Proprietária: CPFL \\
\hline Descrição & \multicolumn{2}{|c|}{$\begin{array}{l}\text { A usina Salto de Pinhal é uma das primeiras usinas instaladas no estado de } \\
\text { São Paulo. A construção das edificações e infraestruturas foram } \\
\text { implementadas na margem direita do Rio Mogi-Guaçu, próximos ao "salto" } \\
\text { que deu nome à usina. Orginalmente, o conjunto edificado era composto de } 4 \\
\text { residências, } 1 \text { escola, a casa de máquinas e três edificações para os } \\
\text { funcionários. A escola original e as residências }(1,2,6,7,8) \text { não existem mais } \\
\text { e os usos foram transferidos para as casas } 3,4 \text { e } 5 \text { até a desativação da usina } \\
\text { em } 1994 \text { (mapa 1). As estruturas das edificações estão em bom estado de } \\
\text { conservação, porém necessitam de reparos. A casa de máquinas ainda possui } \\
\text { os antigos geradores da AEG de Braunschweig, com inscrição das iniciais em } \\
\text { estilo "Art Nouveau", o painel de controle original e as luminárias do tipo } \\
\text { arandela. As demais estruturas como canal de adução, condutos, comportas e } \\
\text { barragens estão em bom estado de conservação. Próximo à usina, na margem } \\
\text { esquerda do Rio Mogi-Guaçu, foi construida a PCH Pinhal, em } 1928 \text {, com } \\
\text { único acesso pela ponte que interliga as duas PCHs. }\end{array}$} \\
\hline $\begin{array}{l}\text { Elementos } \\
\text { característicos }\end{array}$ & \multicolumn{2}{|c|}{$\begin{array}{l}\text { - Barragem em concreto com os muros laterais em enrocamento com } 97 \\
\text { metros e } 4,25 \text { metros de altura; } \\
\text { - Canal de adução alvenaria de pedra argamassada com } 72 \text { metros; } \\
\text { - Comportas em madeira; } \\
\text { - Dois condutos de } 15,3 \text { metros de comprimento e } 1,75 \text { e } 1,95 \text { metros de } \\
\text { diâmetro. } \\
\text { - Casa de força de pequeno porte, em alvenaria de pedra com fundação em } \\
\text { rochas graniticas; } \\
\text {-Vila operária } \\
\text { - Escola }\end{array}$} \\
\hline $\begin{array}{l}\text { Importância } \\
\text { Patrimonial }\end{array}$ & \multicolumn{2}{|c|}{$\begin{array}{l}\text { Valor Histórico-Usina da primeira década do século XX, foi implementada } \\
\text { pela empresa geradora e distribuidora de energia elétrica Companhia Luz } \\
\text { Elétrica e Telefônica Pinhalense, fundada em novembro de } 1896 \text { na cidade } \\
\text { paulista de Espirito Santo do Pinhal, onde o serviço de iluminação pública foi } \\
\text { inaugurado em } 1898 \text {. Posteriormente, a Companhia passou a ser denominada } \\
\text { Empresa Pinhalense de Eletricidade, sendo vendida em } 1920 \text { para a empresa } \\
\text { The Southern Brazil Electric Co., que mudou seu nome para Companhia } \\
\text { Mogiana de Luz e Força integrando a Empresa Elétrica de Itapira, que } \\
\text { explorava o serviço de energia elétrica no vizinho municipio de Itapira desde } \\
1905 \text { e havia sido comprada pela Southern em } 1917 \text {. A Companhia Mogyana } \\
\text { passou a atender os municipios de Espirito Santo do Pinhal e Itapira e em } \\
1929 \text { foi vendida à Amforp (American \& Foreing Power). Em 1950 foi } \\
\text { incorporada à CPFL. Fonte: http://memoriaviva.cpfl.com.br/nossas- } \\
\text { origens/s\%C3\%A3o-paulo/cia-mogiana-de-luz-e-for\%C3\%A7a.aspx?view= }\end{array}$} \\
\hline & & \\
\hline
\end{tabular}


retangular em "L", em um único nível, e dispõe de uma sala anexa. As esquadrias da edificação são constituídas pela porta principal em madeira, com duas folhas retangulares e, acima dela, janelas semicirculares em caixilho de madeira. No alto da fachada, próximo ao telhado há mais duas janelas semicirculares. De cada lado da porta principal há uma janela de abrir, em formato retangular e finalizada em semicírculo. Aquelas localizadas nas laterais são em formato retangular. As residências da vila operária foram construídas em alvenaria de pedra, com telhas de barro e possuem varanda na entrada principal. São exemplares da primeira época da eletrificação.

Valor Paisagístico - A usina foi construída na meia encosta da margem direita do Rio Mogi-Guaçu, próximo à confluência com o Ribeirão da Areia Branca, na zona rural do município. Área de grande beleza cênica, com cobertura vegetal da Floresta Estacional Semidecidual em diversos estágios de sucessão nas proximidades da usina. Essa formação florestal é considerada patrimônio nacional pela Constituição do Brasil de 1988. Defronte à casa de máquinas avista-se a queda d" água, o "salto" que deu nome à usina e onde foi construída a barragem que é compartilhada com a PCH de Pinhal. O Rio Mogi-Guaçu apresenta fluxo turbulento encachoeirado onde avista-se diversas ilhas fluviais florestadas à montante e à jusante das barragens. $\mathrm{O}$ paisagismo da usina é composto por espécies arbóreas nativas e exóticas bem desenvolvidas além de palmeiras. O paisagismo da usina é composto por espécies herbáceas, arbustivas e arbóreas nativas e exóticas além de palmeiras. Nas proximidades observa-se chácaras, pasto e culturas de café e eucalipto. Os acessos são feitos por caminhos de terra. A visibilidade a partir da barragem alcança 1.400 metros até a linha do horizonte para sudoeste onde também se avista as vertentes cobertas pela vegetação arbórea.

Valor Tecnológico - A geração e distribuição de energia hidráulica foi possível a partir das novas tecnologias e materiais empregados nos equipamentos e no campo das engenharias. As máquinas utilizadas nas primeiras PCHs representavam a vanguarda para eletrificação paulista. As novas tecnologias aplicadas eram representadas por:

-Duas unidades do conjunto Turbina (eixo horizontal, tipo Francis) Gerador (eixo horizontal, fabricante $\mathrm{AEG}$ ) que tiveram a velocidade de rotação aumentada em 20\% em 1929.

- Operação da usina por meio de painéis de comando;

- Uso da corrente alternada que, do ponto de vista técnico, apresenta as seguintes vantagens (Carvalho, 1912):

a) possibilidade de construção de unidades de uma potência qualquer e uma tensão qualquer independentemente da voltagem estabelecida para transmissão;

b) independência absoluta das unidades geradoras;

c) regulagem de velocidade constante aplicada em cada uma; 


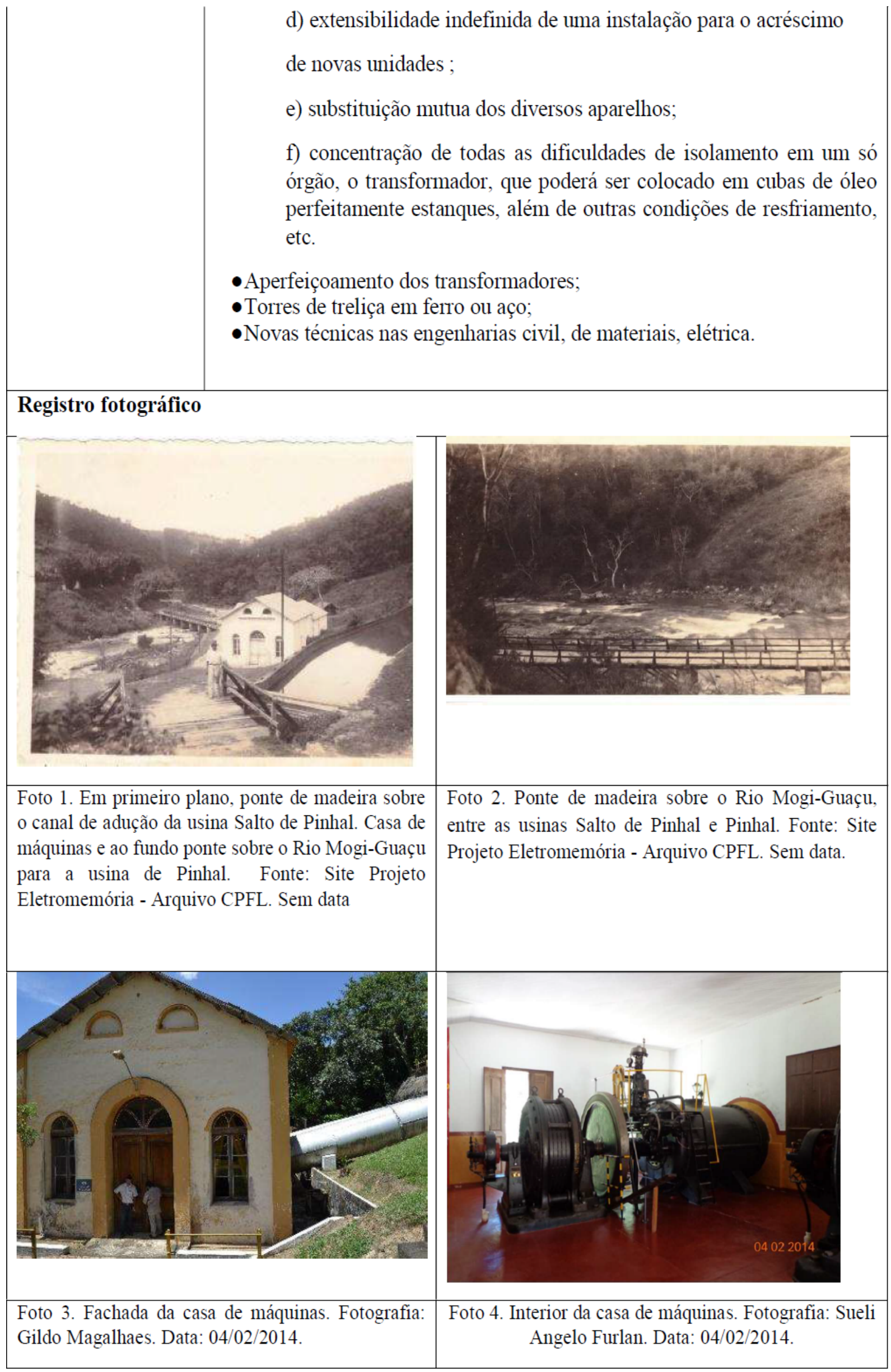




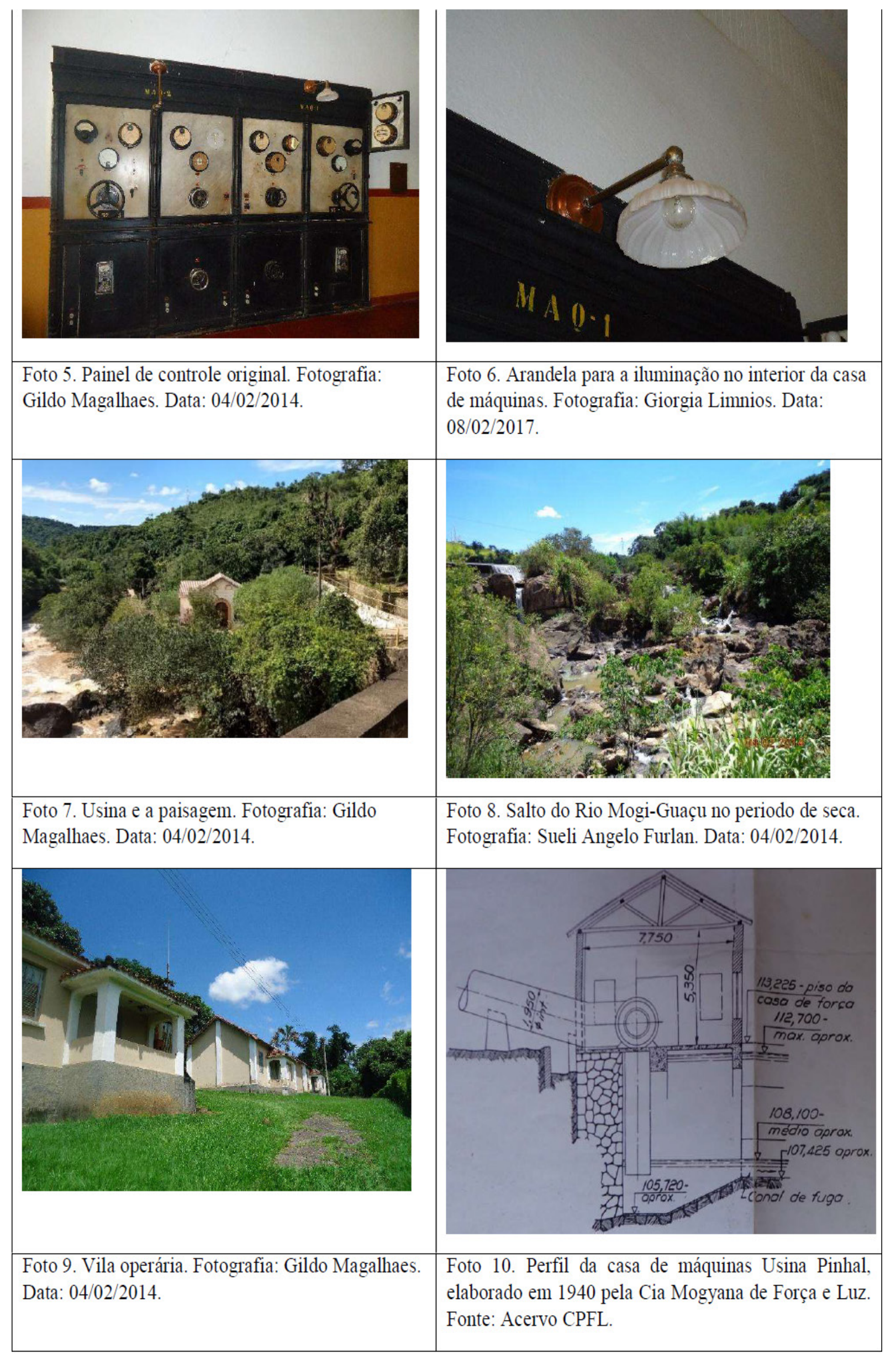


Pequena Central Hidrelétrica Pinhal

\begin{tabular}{|c|c|c|}
\hline $\begin{array}{l}\text { Município: Espírito } \\
\text { Santo do Pinhal }\end{array}$ & Temática: Patrimônio Industrial/Paisagístico & Data: 1928 \\
\hline $\begin{array}{l}\text { Situação: Em } \\
\text { operação }\end{array}$ & Curso d' água: Rio Mogi-Guaçu & Proprietária: $\mathrm{CPFL}$ \\
\hline Descrição & \multicolumn{2}{|c|}{$\begin{array}{l}\text { A usina Pinhal foi construída } 17 \text { anos depois da sua vizinha "Salto de Pinhal" } \\
\text { na meia encosta da margem esquerda do Rio Mogi-Guaçu. Por causa da } \\
\text { proximidade, as duas usinas compartilham a barragem e estão interligadas } \\
\text { pelas linhas de energia e o acesso é feito a partir da usina Salto de Pinhal. O } \\
\text { canal de adução foi construído na meia encosta, na cota altimétrica, } \\
\text { aproximada, de } 665 \text { metros. Devido à ruptura da encosta, ocorrida em agosto } \\
\text { de } 1994 \text {, parte dessa estrutura foi reconstruída assim como o caminho entre } \\
\text { as duas usinas. O gerador original da usina foi desativado e está em exposição } \\
\text { na vila residencial da usina de Americana. }\end{array}$} \\
\hline $\begin{array}{l}\text { Elementos } \\
\text { característicos }\end{array}$ & \multicolumn{2}{|c|}{$\begin{array}{l}\text { - Barragem em concreto com os muros laterais em enrocaento com } 97 \\
\text { metros e 4,25 metros de altura; } \\
\text { - Canal de adução alvenaria de pedra e concreto com } 360 \text { metros de } \\
\text { comprimento; } \\
\text { - Câmara de carga com duas comportas semiautomatizada; } \\
\text { - Dois condutos de } 56 \text { metros de comprimento e } 2,60 \text { metros de diâmetro. } \\
\text { - Casa de máquinas em alvenaria de pedra rejuntada. }\end{array}$} \\
\hline Valor Patrimonial & \multicolumn{2}{|c|}{$\begin{array}{l}\text { Valor Histórico - Usina da primeira década do século XX, foi implementada } \\
\text { pela empresa geradora e distribuidora de energia elétrica Companhia Luz } \\
\text { Elétrica e Telefônica Pinhalense, fundada em novembro de } 1896 \text { na cidade } \\
\text { paulista de Espírito Santo do Pinhal, onde o serviço de iluminação pública foi } \\
\text { inaugurado em 1898. Posteriormente, a Companhia passou a ser denominada } \\
\text { Empresa Pinhalense de Eletricidade, sendo vendida em } 1920 \text { para a empresa } \\
\text { The Southern Brazil Electric Co., que mudou seu nome para Companhia } \\
\text { Mogiana de Luz e Força integrando a Empresa Elétrica de Itapira, que } \\
\text { explorava o serviço de energia elétrica no vizinho município de Itapira desde } \\
1905 \text { e havia sido comprada pela Southern em 1917. A Companhia Mogyana } \\
\text { passou a atender os municípios de Espírito Santo do Pinhal e Itapira e em } \\
1929 \text { foi vendida à Amforp (American \& Foreing Power). Em } 1950 \text { foi } \\
\text { incorporada à CPFL. Fonte: http://memoriaviva.cpfl.com.br/nossas- } \\
\text { origens/s\%C3\%A30-paulo/cia-mogiana-de-luz-e-for\%C3\%A7a.aspx?view= } \\
\text { A usina iniciou sua operação em } 1928 \text { e esteve paralisada entre } 1967 \text { e } 1985 .\end{array}$} \\
\hline & \multicolumn{2}{|c|}{$\begin{array}{l}\text { Valor Arquitetônico - A casa de máquinas foi construída em alvenaria de } \\
\text { pedras rejuntada, com plano geométrico retangular em dois níveis. No térreo } \\
\text { estão localizados os equipamentos de geração de energia e o nível superior, } \\
\text { cujo acesso se dá por uma escada de madeira bem inclinada, abriga a sala de } \\
\text { comando. A porta principal é constituída por duas folhas de madeira, }\end{array}$} \\
\hline
\end{tabular}




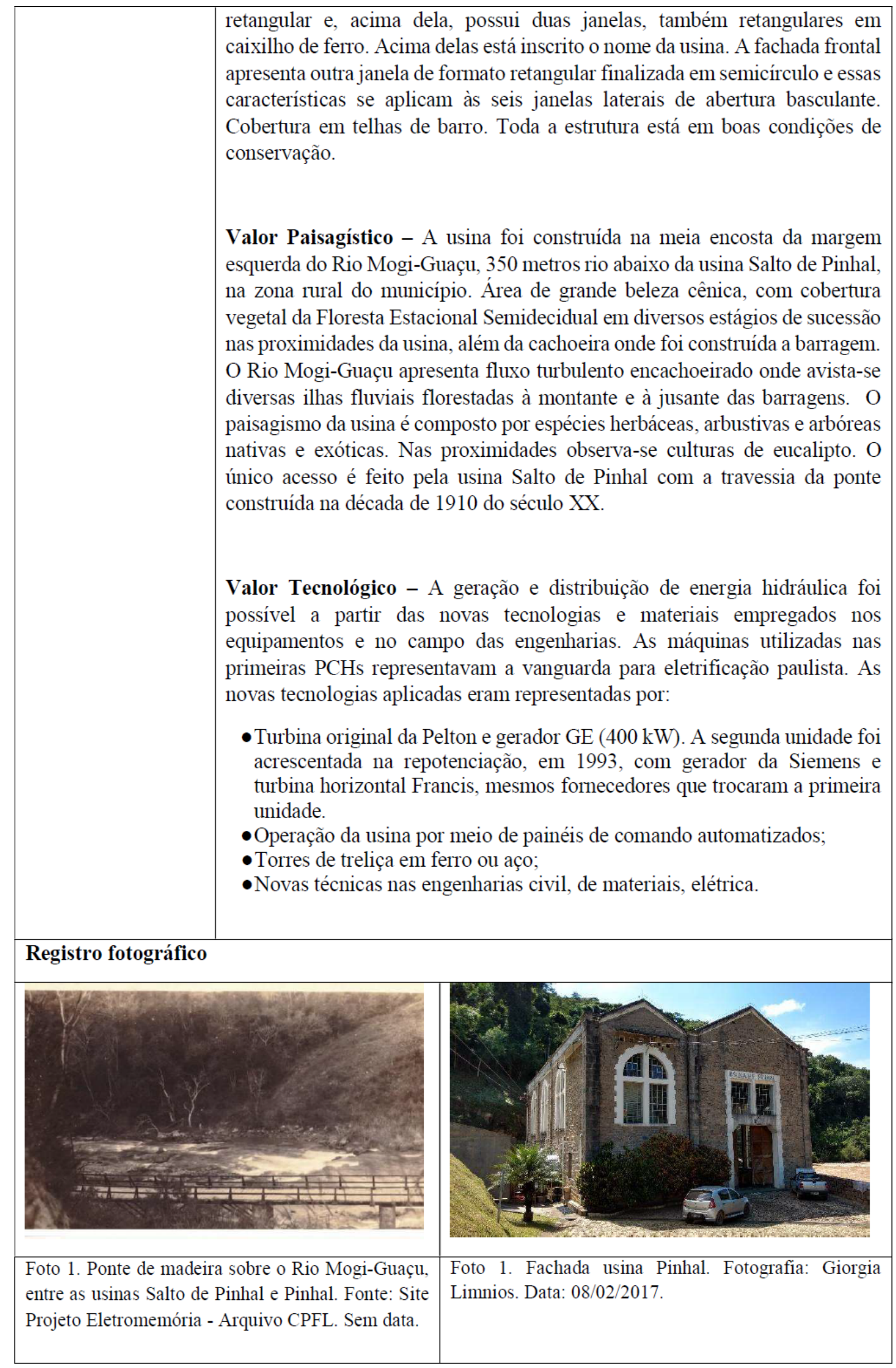



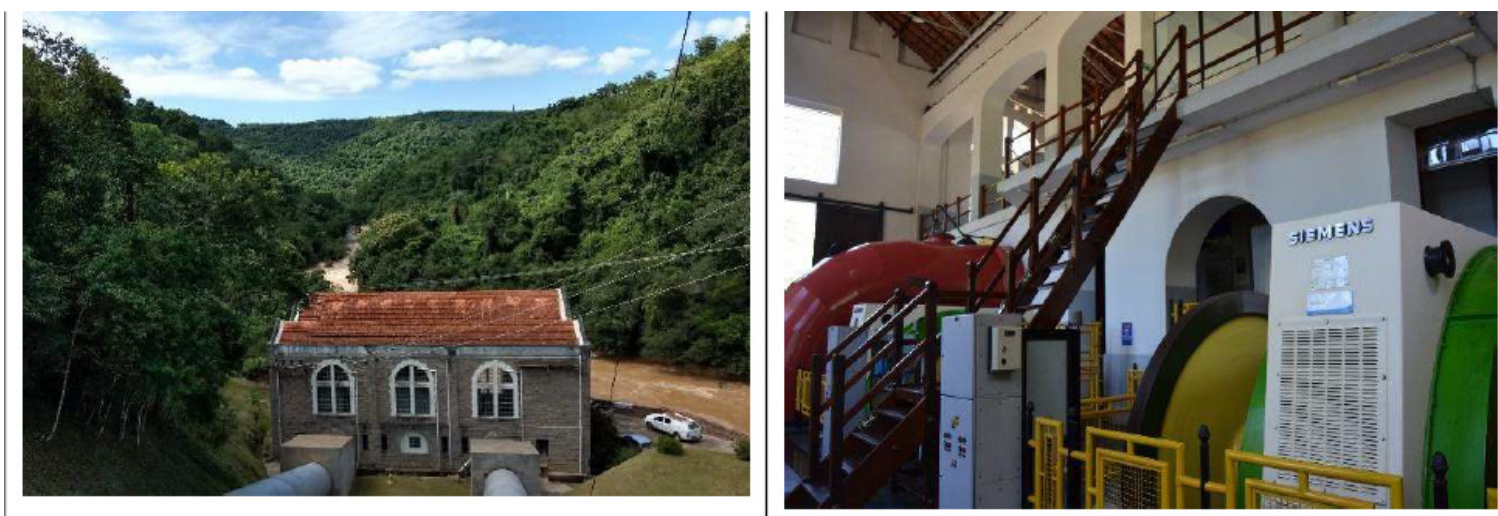

Foto 3. Vista lateral da casa de máquinas e paisagem. Fachada da casa de máquinas. Fotografia: Giorgia Limnios. Data: 08/02/2017.

Foto 4. Interior da casa de máquinas. Fotografia: Gildo Magalhaes. Data: 04/02/2014.
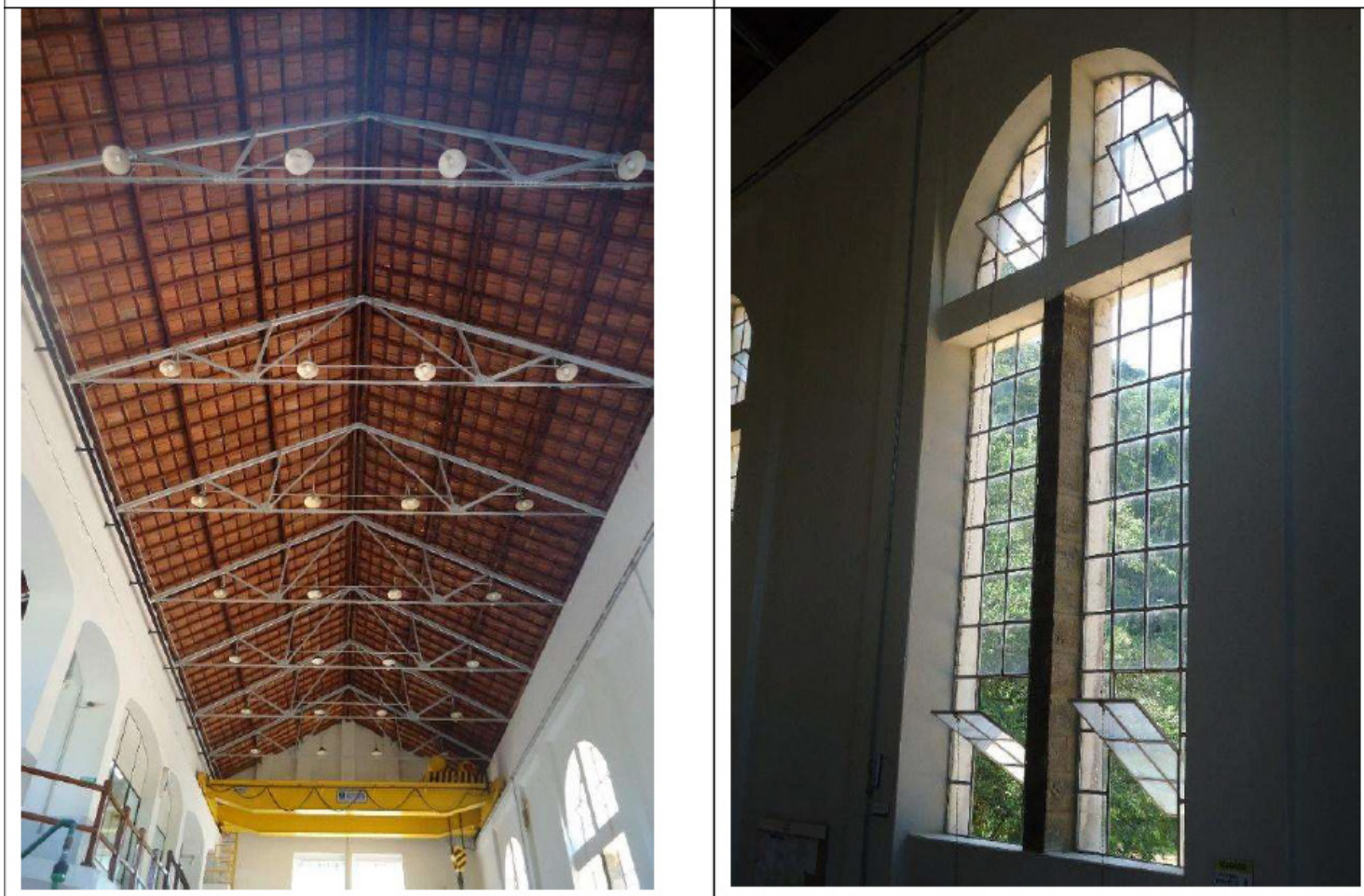

Foto 5. Teto da casa de máquinas. Fotografia: Giorgia Limnios. Data: 08/02/2017.

Foto 6. Janela da casa de máquinas. Fotografia: Giorgia Limnios. Data: 08/02/2017. 


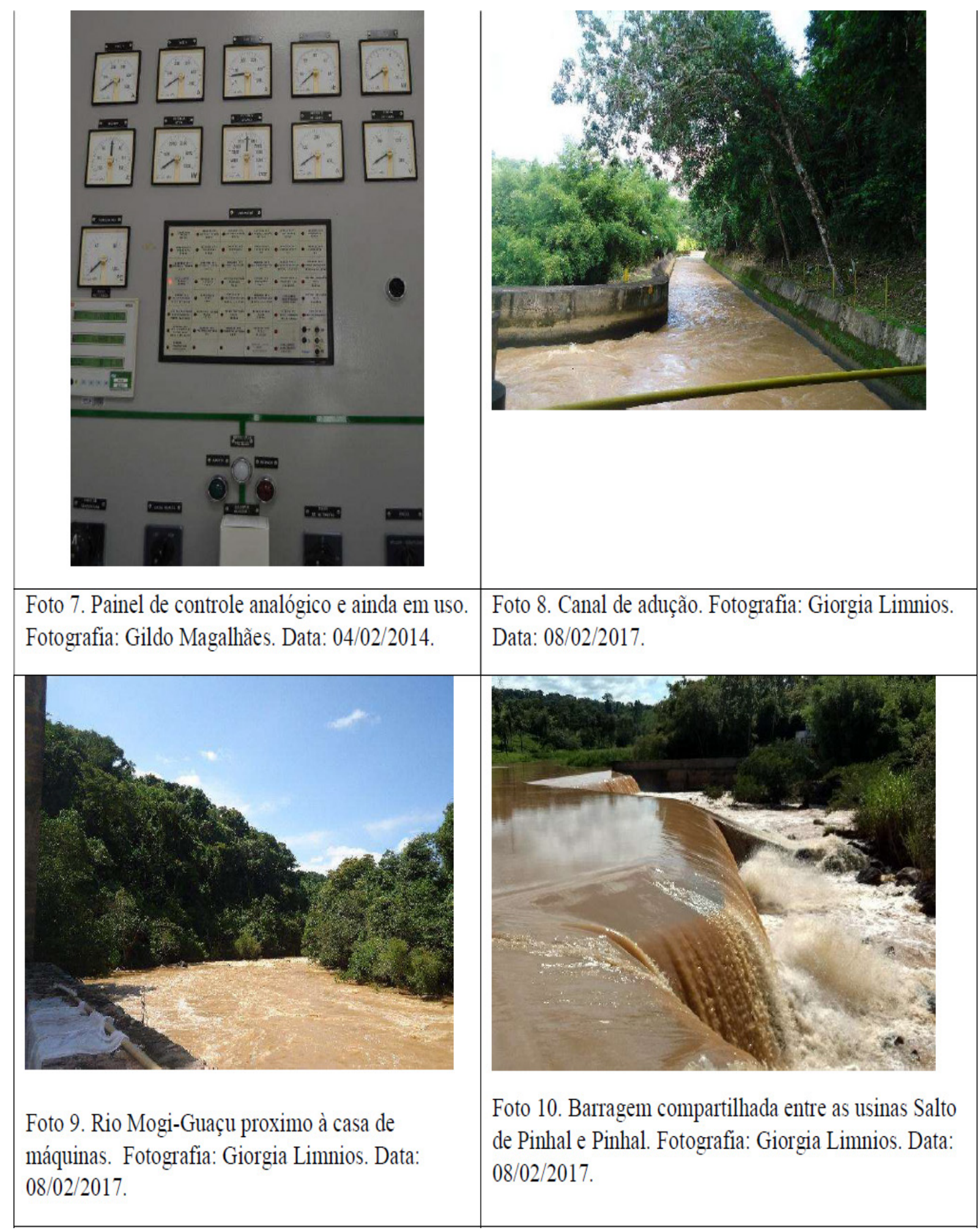




\section{Infraestrutras Pequenas CentraisHidrelétricas Salto de Pinhal e Pinhal em 1962 e 2010 Espírito Santo do Pinhal/SP}

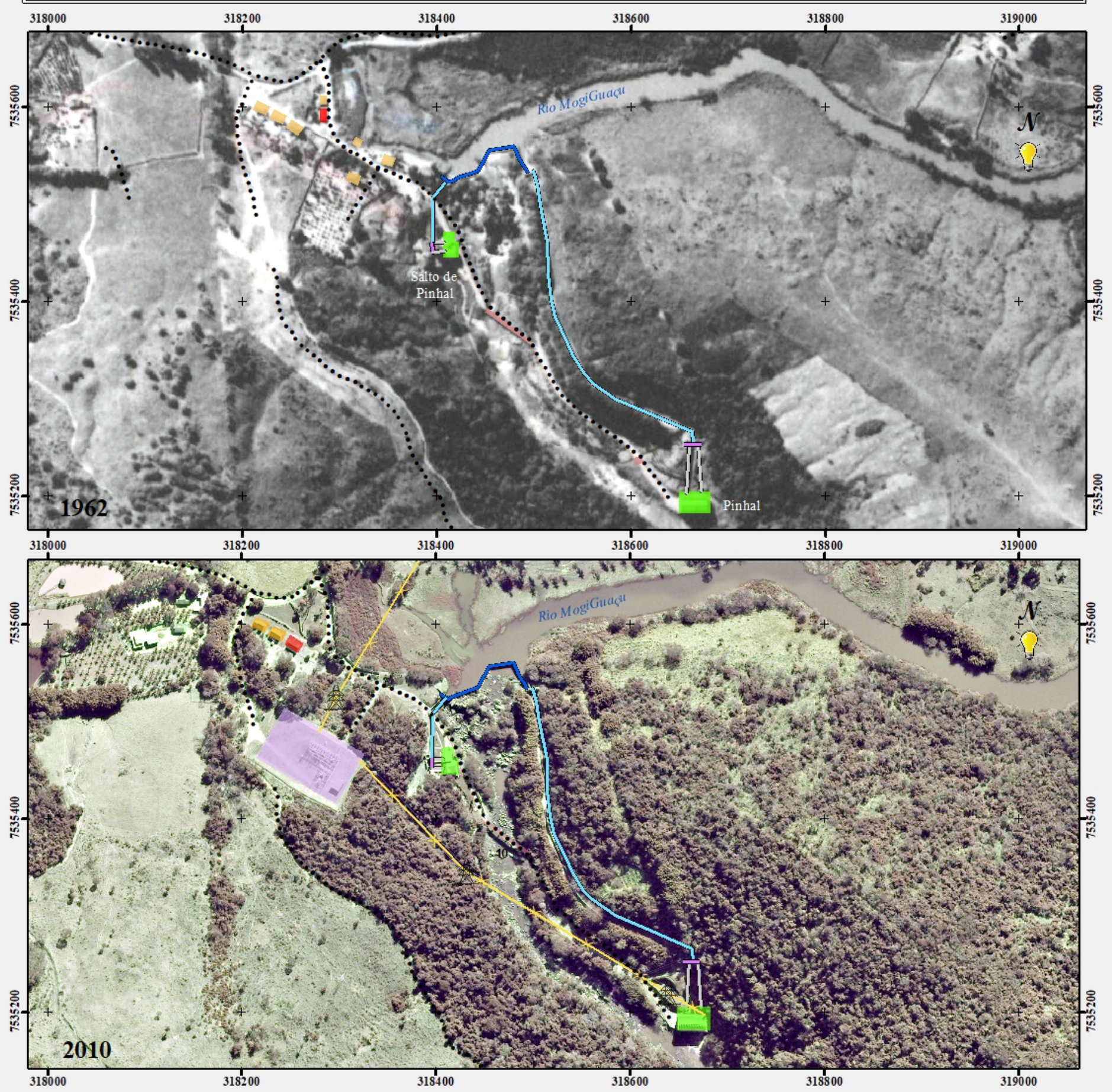

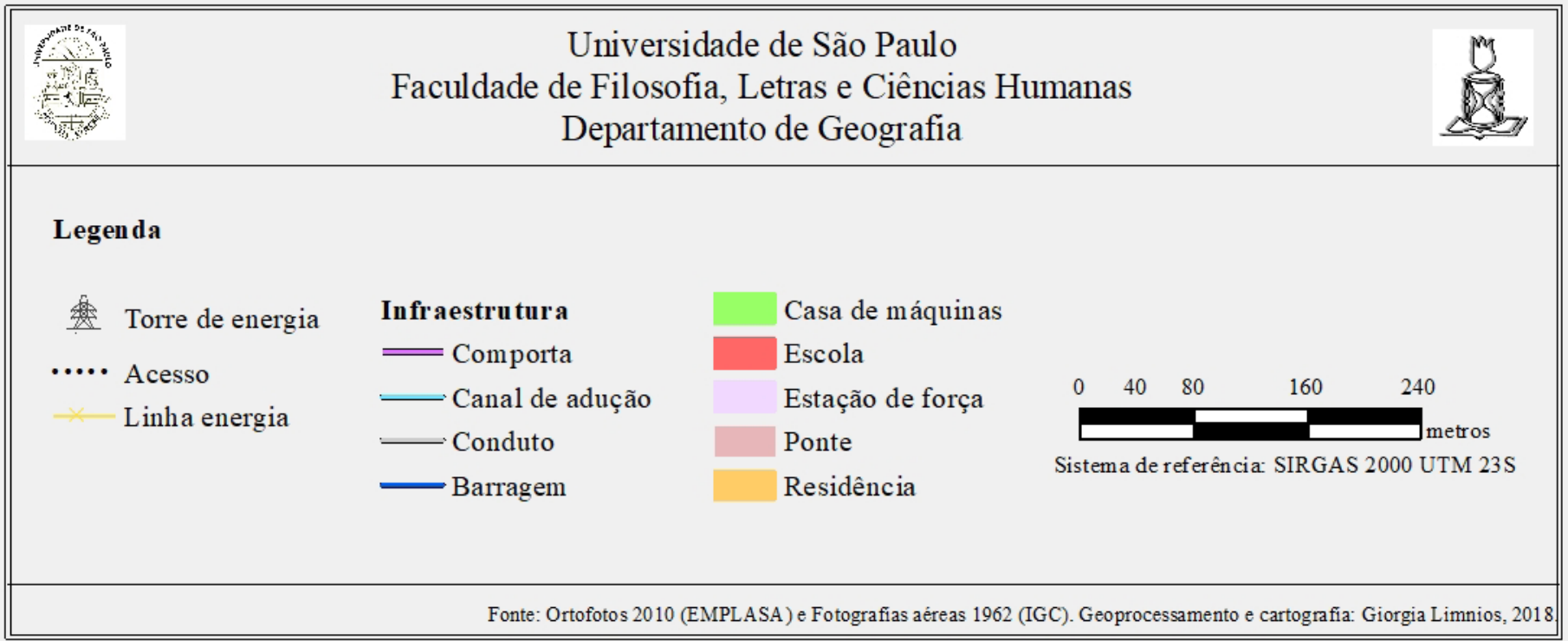


Pequena Central Hidrelétrica Eloy Chaves

\begin{tabular}{|c|c|c|}
\hline $\begin{array}{l}\text { Município: Espirito } \\
\text { Santo do Pinhal }\end{array}$ & $\begin{array}{l}\text { Temática: Patrimônio } \\
\text { Industrial/Paisagístico }\end{array}$ & Data: 1954 \\
\hline Situação: Em operação & Curso d' água: Rio Mogi-Guaçu & Proprietária: CPFL \\
\hline Descrição & \multicolumn{2}{|c|}{$\begin{array}{l}\text { A usina Eloy Chaves está localizada } 6 \mathrm{~km} \text { rio acima da barragem das } \\
\text { usinas Pinhal e Salto de Pinhal, na margem esquerda do Mogi-Guaçu. A } \\
\text { usina pertenceu a Eloy de Miranda Chaves, um dos pioneiros do setor } \\
\text { elétrico paulista e proprietário de outras usinas no interior de São Paulo, a } \\
\text { saber: Usina Monte Serrat (1905) e Usina Quilombo (1913), em Jundiaí; } \\
\text { Usina do Corumbataí (1895), em Rio Claro; Usinas Emas Velha (1922) e } \\
\text { Emas Nova, em Pirassununga; Usina do Tatu ou Ribeirão do Pinhal } \\
\text { (1924), em Limeira; Usina Lobo (1936), em Itirapina; Usina do Jacaré } \\
\text { (1927), em Brotas e Usina Jacutinga, na cidade do mesmo nome no Estado } \\
\text { de Minas Gerais. Foi um dos fundadores da Empresa Luz e Força de } \\
\text { Jundiaí em 1905, adquirida pela Light } 15 \text { anos depois. Também foi } \\
\text { proprietário de companhias já existentes, como a Empresa Força e Luz de } \\
\text { Mogi Mirim, Empresa Melhoramentos de Mogi-Guaçu e Companhia Luz } \\
\text { e Força Jacutinga, que se associaram à S.A. Central Elétrica Rio Claro - } \\
\text { SACERC. Também foi proprietário de termoelétricas em Rio Claro, Três } \\
\text { Lagoas e Jundiaí. (MORTATI, 2013). }\end{array}$} \\
\hline $\begin{array}{l}\text { Elementos } \\
\text { característicos }\end{array}$ & $\begin{array}{l}\text { - Barragem em concreto-gravidade co } \\
\text { metros. } \\
\text { - Vertedouros de superfície com comp } \\
\text { - Câmara de compensação e câmara d } \\
\text { - Chaminé de equilíbrio; } \\
\text { - Dois condutos de baixa pressão com } \\
\text { outros dois segmentos de alta pressã } \\
\text { 2, } 60 \text { metros. } \\
\text { - Casa de máquinas em alvenaria de ti } \\
\text { - Vila operária; }\end{array}$ & $\begin{array}{l}\text { metros e altura de } 21 \\
\text { de } 10 \text { metros de largura; } \\
\text { a; } \\
\text { metros de extensão e } \\
226 \text { metros e diâmetro de }\end{array}$ \\
\hline
\end{tabular}

Valor Histórico - A usina entra em operação em 1954 para complementar o fornecimento de energia em razão da crise energética vigente no período de 1946 a 1955, momento de grande crescimento industrial e demográfico paulista, além de estiagens que afetaram tanto a produção como a distribuição de energia. Para aumentar a capacidade produtiva, o porte da usina refletia tal necessidade. Foi construída pela CPFL que tem como origem a Companhia Luz Eletrica e Telefônica Pinhalense, fundada em novembro de 1896 na cidade paulista de Espírito Santo do Pinhal, onde o serviço de iluminação pública foi inaugurado em 1898. Posteriormente, a Companhia passou a ser denominada Empresa Pinhalense de Eletricidade, sendo vendida em 1920 para a empresa The Southern Brazil Electric Co., que mudou seu nome para Companhia Mogiana de Luz e Força integrando 
Valor Patrimonial a Empresa Elétrica de Itapira, que explorava o serviço de energia elétrica no vizinho município de Itapira desde 1905 e havia sido comprada pela Southern em 1917. A Companhia Mogyana passou a atender os municípios de Espírito Santo do Pinhal e Itapira e em 1929 foi vendida à Amforp (American \& Foreing Power). Em 1950 foi incorporada à CPFL. Fonte: $\quad$ http://memoriaviva.cpfl.com.br $/$ nossas-origens $/ \mathrm{s} \% \mathrm{C} 3 \% \mathrm{~A} 30-$ paulo/cia-mogiana-de-luz-e-for $\% \mathrm{C} 3 \% \mathrm{~A} 7 \mathrm{a}$.aspx?view $=$

Valor Arquitetônico - A casa de máquinas foi construída em alvenaria de tijolos, em plano geométrico retangular com dois níveis. No térreo estão localizados os equipamentos de geração de energia e o nível superior, abriga a sala de comando. As esquadrias da edificação são compostas pela porta principal, de formato retangular, constituída por vidros em caixilho de ferro abrigado por uma marquise de concreto. Acima da porta, há uma grande janela retangular, em caixilho de ferro com abertura basculante e essas características se aplicam às janelas laterais inferiores e superiores. A denominação da usina está gravada na fachada. Faz parte do conjunto industrial a vila residencial com edificações localizadas nas proximidades da barragem e da casa de máquinas.

Valor Paisagístico - As estruturas da usina foram construídas na margem esquerda do Rio Mogi-Guaçu, na zona rural do município. Área de grande beleza cênica, com cobertura vegetal da Floresta Estacional Semidecidual em diversos estágios de sucessão nas proximidades da usina. O Rio MogiGuaçu apresenta fluxo turbulento encachoeirado onde avista-se diversas ilhas fluviais florestadas à montante e à jusante das barragens. No período de construção da usina a área rural estava bastante degradada em virtude de intensos usos da terra para a agricultura e pastagem, e alguns fragmentos florestais existentes foram retirados para a execução da obra. Desde então, observa-se a regeneração da cobertura vegetal nativa, em especial nas áreas entre as três PCHs, até mesmo nas ilhas fluviais deste trecho. O paisagismo da usina é composto por espécies herbáceas, arbustivas e arbóreas nativas e exóticas bem cuidadas, além de palmeiras. Nas proximidades observa-se chácaras, pasto e culturas de café e eucalipto. Os acessos são feitos por caminhos de terra e por pontes ligando as duas margens.

Valor Tecnológico - As tecnologias de operação e transmissão de energia já eram bastante conhecidas e avançadas em meados do século XX. Verifica-se a preferência por empreendimentos hidrelétricos cada vez maiores, com mais unidades geradoras de energia e com maiores alcances espaciais. A usina reflete, em parte, esses novos modelos. A casa de máquinas apresenta características parecidas, em relação ao tamanho e volume, das primeiras PCHs, porém abriga duas unidades turbina (eixo vertical Francis) gerador (eixo vertical Allis Chalmer e Siemens) capazes 
de gerar mais energia. A maior diferença está nas dimensões da barragem (142 m comprimento X 21 metros altura) e no volume de água represado $\left(0,47 \mathrm{~km}^{2}\right.$ área e volume $\left.1,25 \times 10^{6} \mathrm{~m}^{3}\right)$ o que propicia maior vazão turbinada. Essa usina, praticamente, nasce automatizada e é um bom exemplo dessa fase de transição entre hidrelétricas de menor e maior capacidade produtiva.

\section{Registro fotográfico}
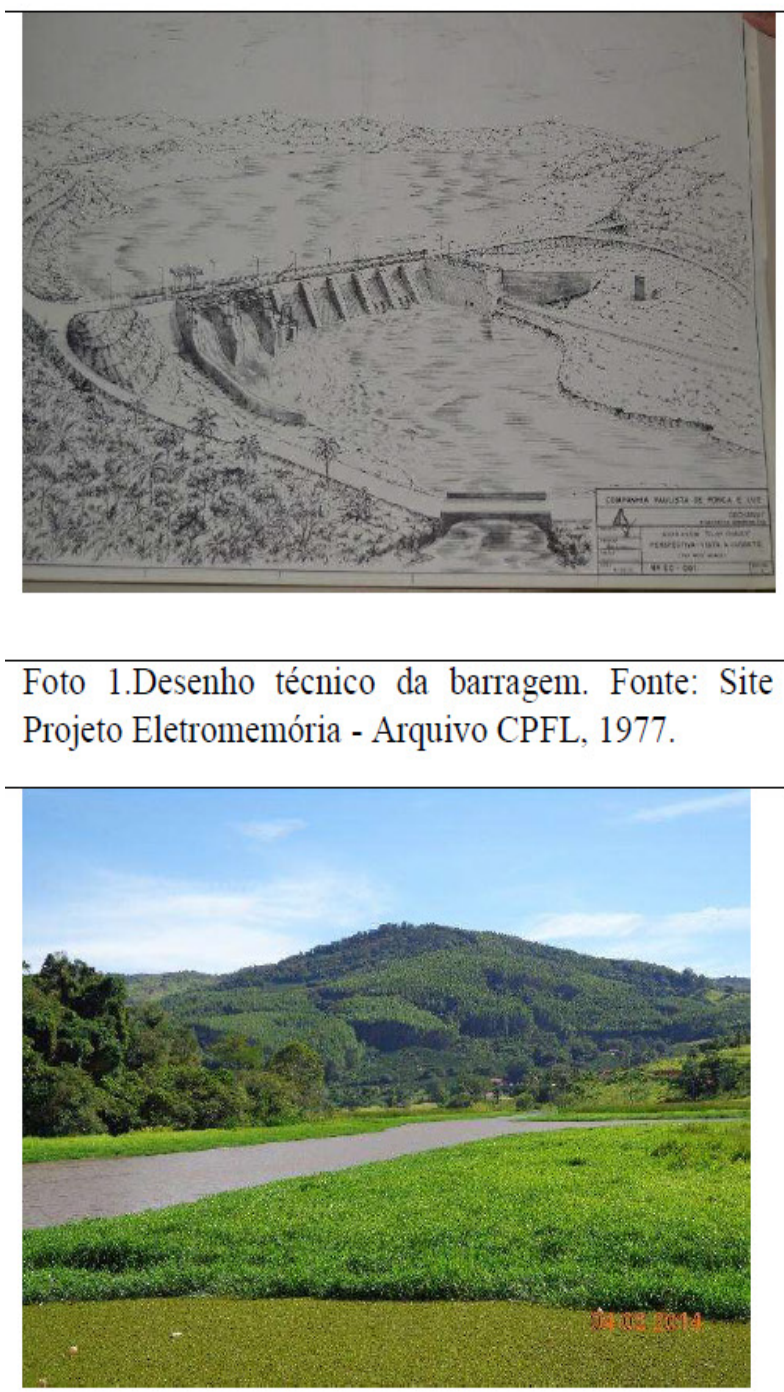

Foto 1. Construção da usina na década de 1950. Fonte: Site Projeto Eletromemória - Arquivo CPFL.

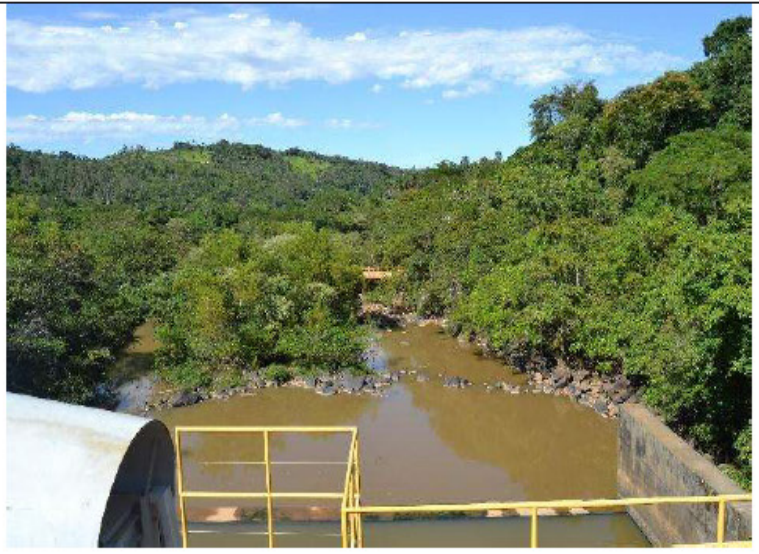

Foto 3. Vista da barragem para a represa. Fotografia: Sueli Angelo Furlan. Data: 04/02/2014.

Foto 4. Vista da barragem para o Rio Mogi-Guaçu e ilha fluvial. Fotografia: Gildo Magalhães. Data: $04 / 02 / 2014$. 

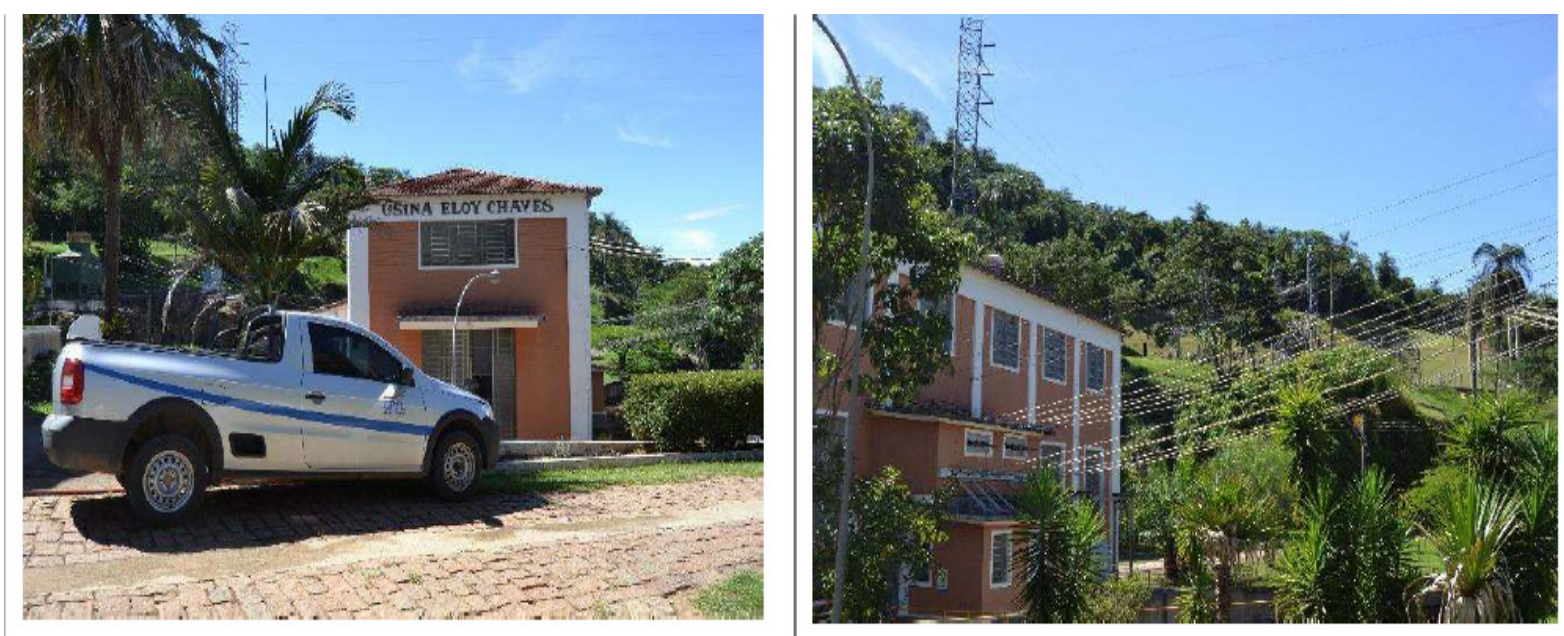

Foto 5. Fachada da casa de máquinas. Fotografia: Gildo Magalhães. Data: 04/02/2014.

Foto 6. Fachada lateral da casa de máquinas. Fotografia: Gildo Magalhães. Data: 04/02/2014.
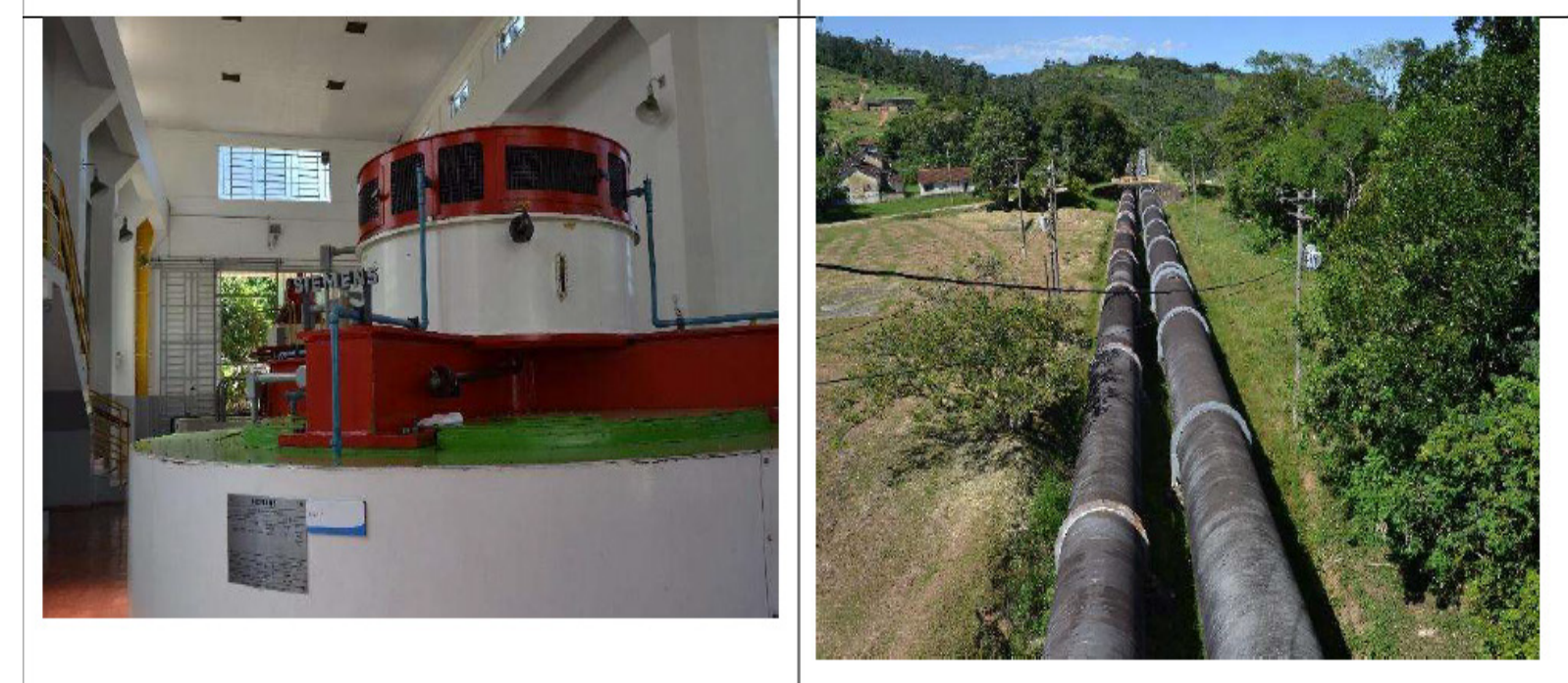

Foto 7. Interior da casa de máquinas. Fotografia: Gildo Magalhães. Data: 04/02/2014.

Foto 8. Canal de adução e vila operária. Fotografia: Gildo Magalhães. Data: 04/02/2014.

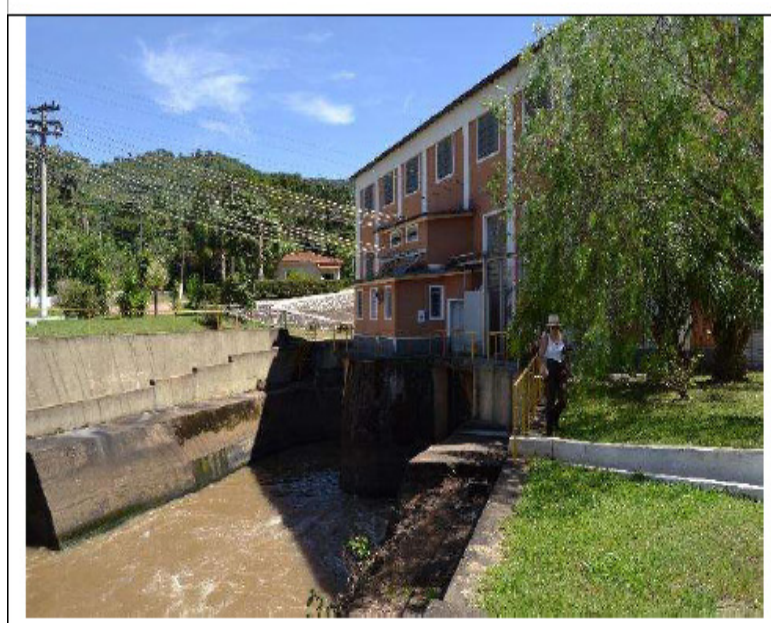

Foto 9. Canal de fuga da casa de máquinas.

Fotografia: Gildo Magalhães. Data: 04/02/2014.

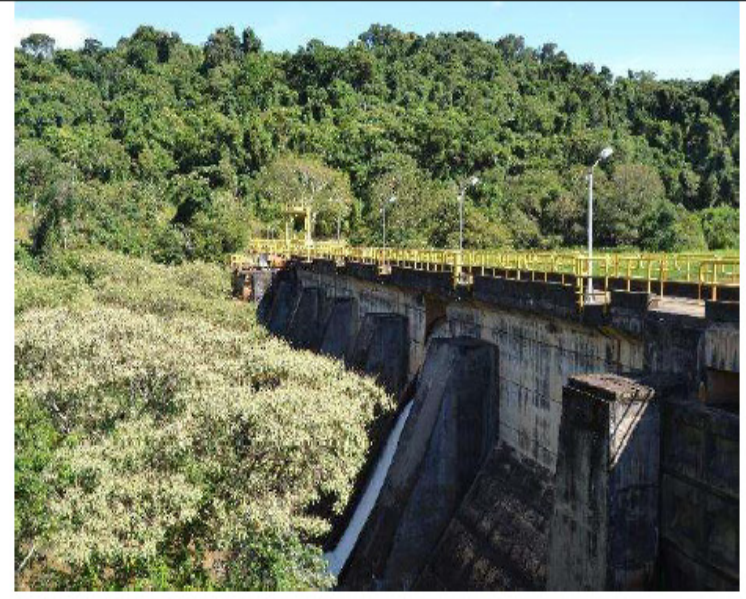

Foto 10. Vista da barragem. Fotografia: Gildo Magalhães. Data: 04/02/2014. 
Mapa 4

\section{Infraestrutras Pequena Central Hidrelétrica Eloy Chaves em 1962 e 2010 Espírito Santo do Pinhal/SP}

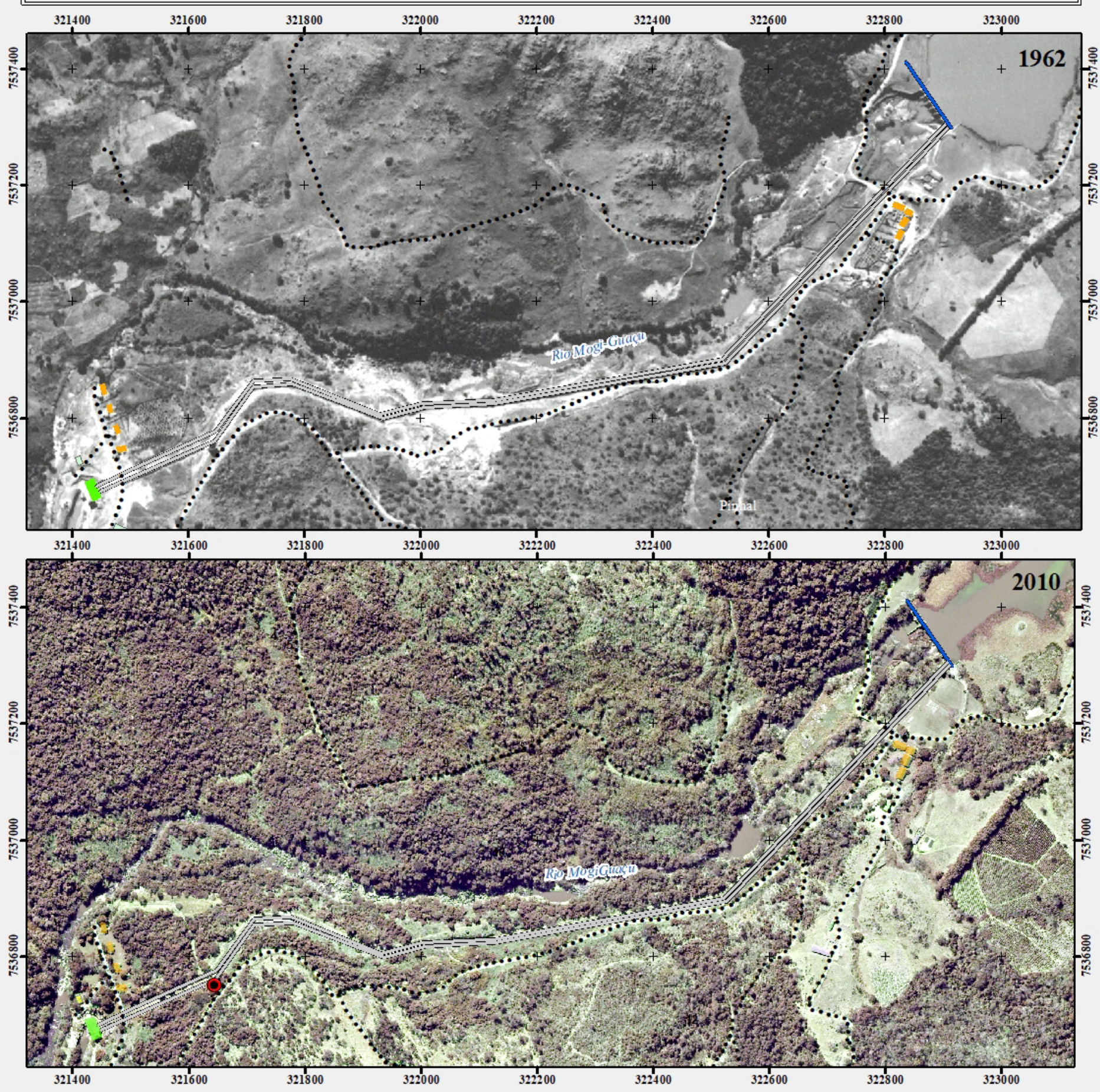

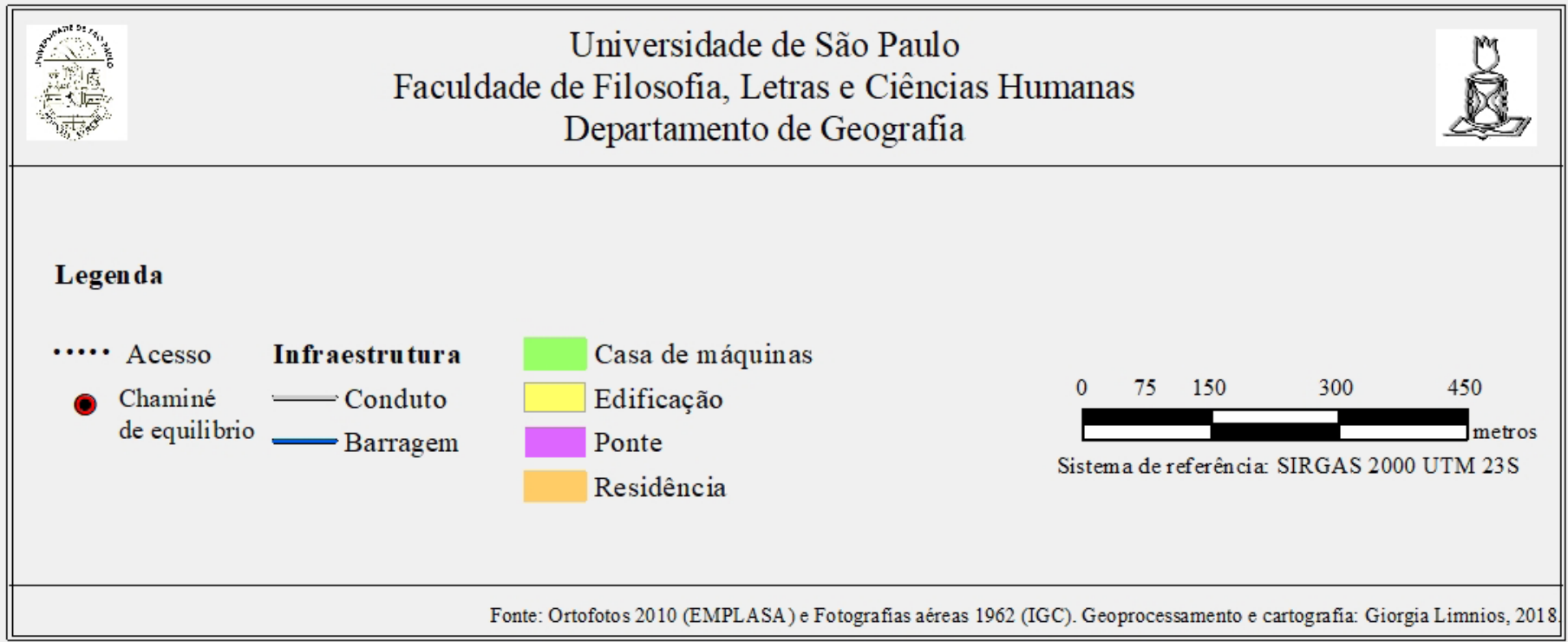




\section{Resultados - Ecologia da Paisagem}

A partir da interpretação visual e mapeamento de uso e cobertura da terra, na escala 1.5000 , foram determinadas 17 classes para a paisagem rural pesquisada, divididas nas categorias cultural e natural. A primeira envolve 12 classes e a segunda 5 classes respectivamente (Mapa 5).

Da análise visual de fotografias aéreas de 1962 e 2010 percebe-se o restabelecimento das coberturas vegetais da Floresta Estacional Semidecidual (FES). Em determinados locais, apresenta crescimento lento ou e/ou baixa capacidade colonização e tais situações podem estar associadas à intensa degradação dos solos, historicamente causado pelas atividades agrícolas e agropecuárias. Nas áreas de pastagens verifica-se a ocorrência de processos erosivos, principalmente nos fundos de vale desprovidos de cobertura arbórea.

Pode-se afirmar que as terras situadas na margem direita do Rio Mogi-Guaçu são predominantemente culturais, com notável extensão de pastagens e cafezais, diferente do predomínio natural da margem esquerda.

As áreas culturais que serão selecionadas para indicação de proteção patrimonial correspondem àquelas onde estão incluídas as infraestruturas/edificações associadas as pequenas centrais hidrelétricas. Estas pertencem à categoria cultural. Todas as classes da categoria natural serão consideradas parte da paisagem a ser protegida devido à relevância social, funções ecossistêmicas e ecológicas, bem como pelo aspecto marcante na paisagem. A seleção das manchas correspondentes irá refletir os melhores resultados das métricas ecológicas, de forma a considerar a sustentabilidade da paisagem.

Na tabela 1 estão representadas as classes conforme as métricas. Sendo a Métrica 1 Total de manchas por classe e total na paisagem (NP), a heterogeneidade, e a Métrica 2 - Área da Classe (CA), a análise da área.

\begin{tabular}{|l|c|c|}
\hline \multicolumn{1}{|c|}{ Uso e Cobertura da Terra } & $\begin{array}{c}\text { Total de } \\
\text { manchas } \\
\text { (NP) }\end{array}$ & $\begin{array}{c}\text { Área total classe (ha) } \\
\text { (CA) }\end{array}$ \\
\hline Cultural & 18 & 193,73 \\
\hline Agricultura de café & 10 & 41,21 \\
\hline Agricultura de café abandonado & 11 & 124,64 \\
\hline Agricultura de eucalipto & 7 & 9,04 \\
\hline Agricultura não identificada & 43 & 136,65 \\
\hline Cobertura vegetal predominantemente herbácea & 33 & 10,64 \\
\hline Corpo d'água & 16 & 12,51 \\
\hline Infraestrutura verde & 46 & 53,86 \\
\hline Infraestrutura/edificação & & \\
\hline
\end{tabular}




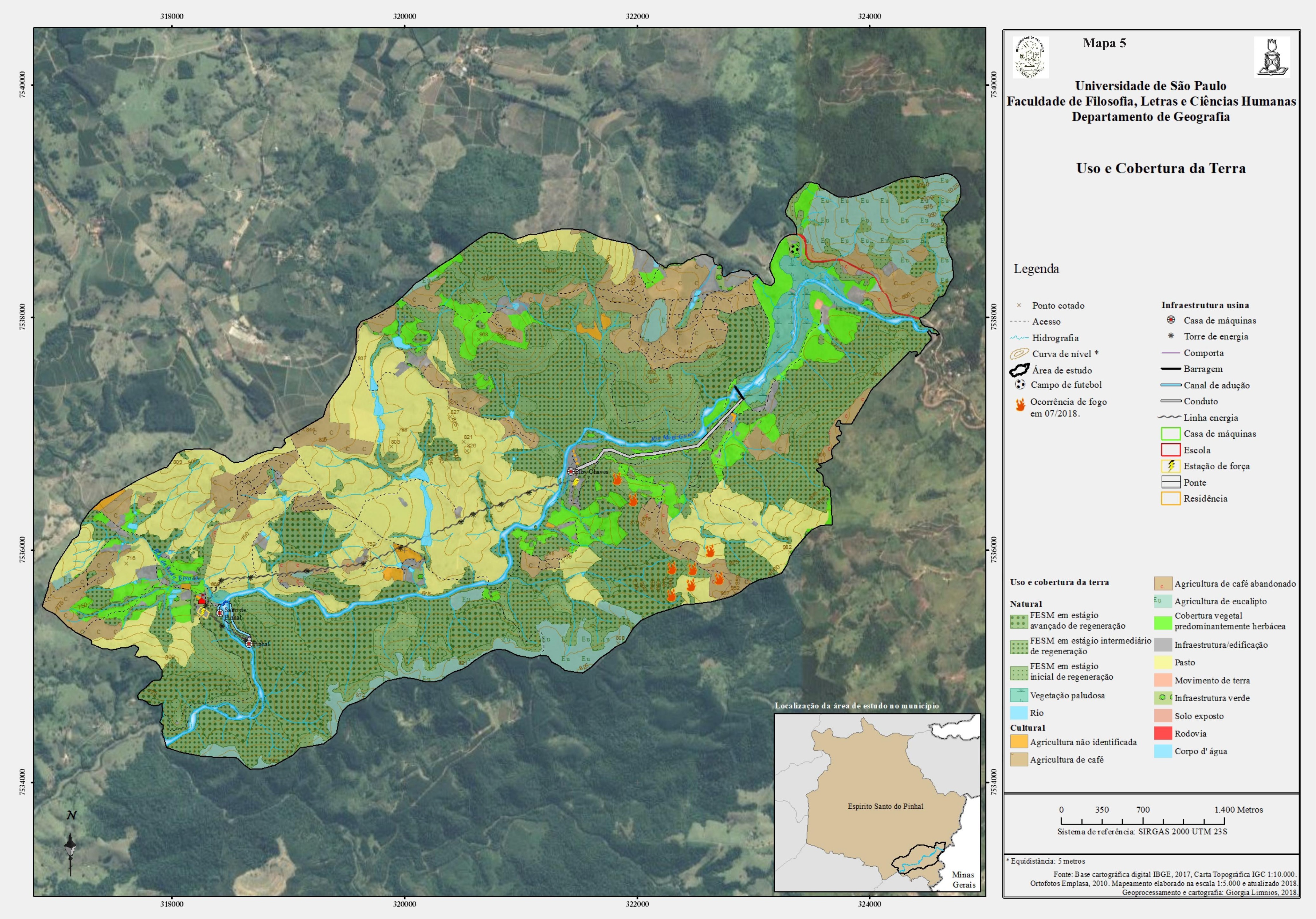




\begin{tabular}{|l|c|c|}
\hline Movimento de terra & 3 & 0,68 \\
\hline Pasto & 12 & 478,87 \\
\hline Rodovia & 1 & 1,94 \\
\hline Solo exposto & 2 & 0,32 \\
\hline Natural & 106 & 292,88 \\
\hline FES em estágio inicial de sucessão & 76 & 460,58 \\
\hline FES em estágio intermediário de sucessão & 19 & 191,64 \\
\hline FES em estágio avançado de sucessão & 3 & 32,76 \\
\hline Vegetação paludosa & 1 & 34,01 \\
\hline Rio & $\mathbf{4 0 7}$ & $\mathbf{2 . 0 7 5 , 9 6}$ (ha) \\
\hline Total Paisagem
\end{tabular}

Tabela 1 - Classes de uso e cobertura da terra e respectivas métricas. Fonte: Giorgia Limnios, 2018.

O recorte paisagístico é composto por 17 classes que totalizam 407 manchas em uma superfície de 2.075,96 hectares. A classe que apresenta o maior quantitativo de manchas (NP) refere-se à Floresta Estacional Semidecidual (FES) em estágio inicial de sucessão com 106 unidades, que ocupam 292,88 ha. Essas áreas estão localizadas próximas e entre as florestas mais desenvolvidas, bem como em locais de nascentes e fundos de vales, próximos aos cursos d' água. Com o desenvolvimento dessa cobertura vegetal, a área florestal pode ter um bom incremento na paisagem com funções ecossistêmicas importantes como estabilização dos terrenos, maior capacidade de reservação de água e melhor qualidade, proteção da biodiversidade, entre outras; e ecologicamente podem potencialmente conectar alguns fragmentos e auxiliar a função de dispersão de espécimes animais e vegetais. Das classes de vegetação nativa, a que possui maior área de cobertura é a FES em estágio intermediário de sucessão com 460,58 ha e todas as coberturas florestais naturais correspondem a um pouco mais da metade do total de manchas, com 201 fragmentos, equivalente a 945,10 hectares. Se for considerado o tipo vegetacional, ou seja, uma única classe FES para todos os estágios sucessionais, o número de fragmentos diminui para 96. No mapa 6 podemos verificar que existe muitos fragmentos pequenos e poucos fragmentos maiores, estes últimos correspondem, no geral, às coberturas em estágio intermediário e avançado de sucessão. 


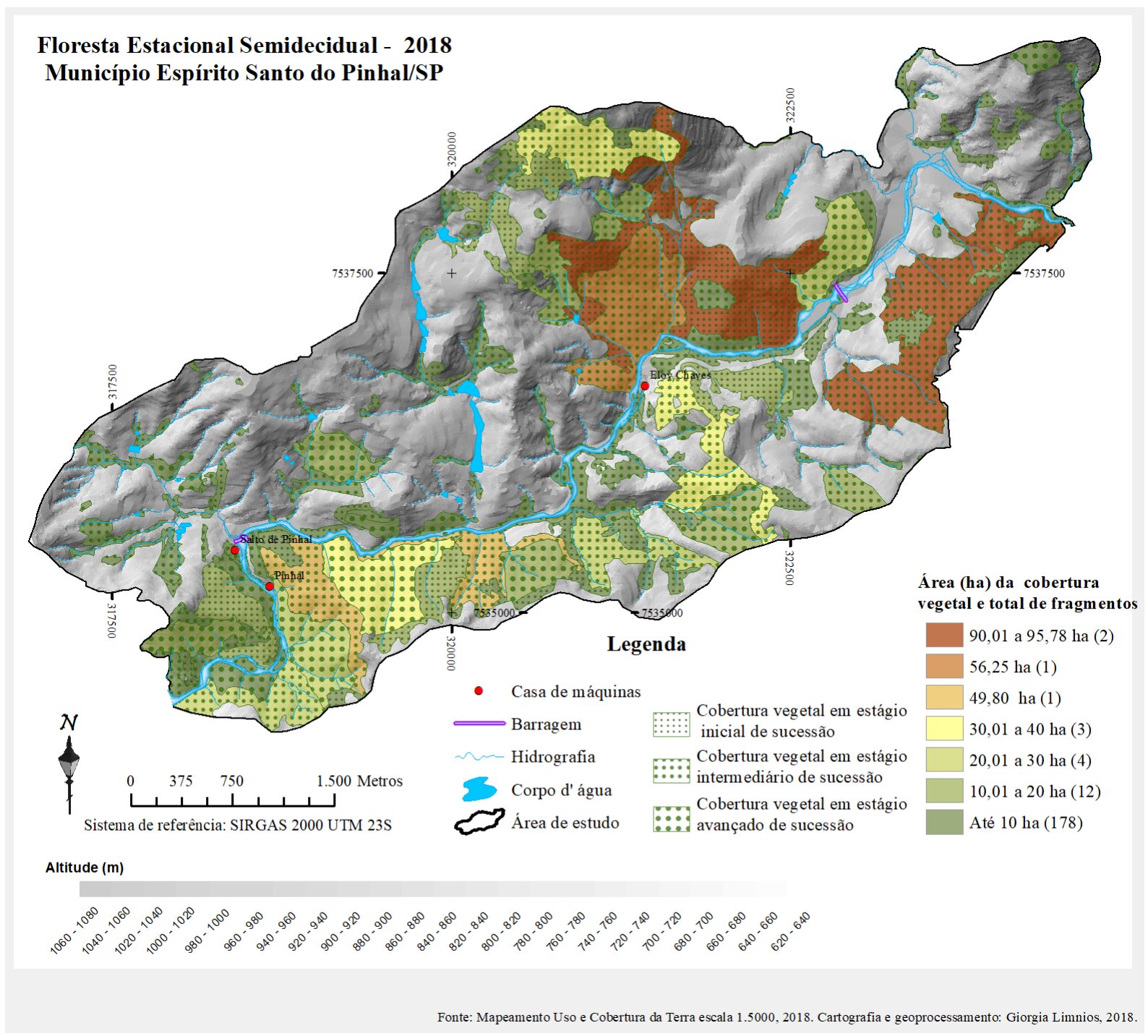

Mapa 6 - Total de fragmentos e área dos remanescentes florestais da Floresta Semidecidual Estacional.

As áreas utilizadas para a agricultura somam 36 manchas que abrangem as culturas de eucalipto, café e outras não identificadas, numa superfície de 327,41 ha. A agricultura não identificada é do tipo temporária e está associada à pequena produção, em virtude da reduzida área cultivada. A área plantada do eucalipto vem aumentando no município de Espírito Santo do Pinhal desde 2014, muitas vezes ocupando as áreas antes destinadas à produção de café. Há também 10 manchas de culturas de café sem manejo, que evidenciam o abandono dessa atividade, devido ao desenvolvimento de outras espécies vegetais em meio ao cafezal.

A área de estudo possui diversos cursos d' água perenes distribuídos em 38 sub-bacias do Rio Mogi-Guaçu, sendo 22 na margem esquerda e 16 na margem direita, em geral de baixas ordens $\left(1^{\mathrm{a}}, 2^{\mathrm{a}}\right.$ e $\left.3^{\mathrm{a}}\right)$. Diversos rios apresentam barramentos, a partir da confluência das drenagens 
de primeira ordem, formando corpos d'água que totalizam 33 manchas com superfície de 10,64 hectares, a maioria localizada na margem direita do rio Mogi-Guaçu e não possuem cobertura vegetal protetora.

Uma classe bastante representativa, no que se refere à área, é o uso para pasto. Ocupa quase $1 / 4$ da paisagem total pesquisada, com 460,58 ha distribuídos em 12 manchas, localizadas principalmente na margem esquerda do Rio Mogi-Guaçu. Apesar das poucas manchas, estas são bastante consideráveis na sua extensão.

As infraestruturas foram relacionadas em duas classes, uma associada à cobertura vegetal arbórea presente nos limites de propriedade, como cerca viva ou barra vento, como acompanhamento viário ou no paisagismo. A outra está relacionada às edificações de propriedades rurais, às estruturas de produção agrícola e de produção de energia, podendo conter algumas espécies vegetais arbóreas/arbustivas entre esses tipos de coberturas. A primeira apresenta 16 manchas com superfície de 12,51 ha e a segunda apresenta 46 manchas com 53,86 ha no total.

Na paisagem, existe duas classes de característica linear, além das matas ciliares, que foram mapeadas como área devido à significativa largura e extensão. São elas a rodovia e o rio. Enquanto a primeira tem como principal característica a artificialidade e função de barreira para muitas espécies da fauna e flora, a segunda é determinada por sua naturalidade, mas pode ser tanto barreira como corredor de espécies, pois o rio Mogi-Guaçu, no trecho da área de estudo tem fluxo interrompido e modificado pelas barragens, principalmente pela PCH Eloy Chaves. A rodovia é também um corredor, mas essa função é bem menos utilizada pelos animais devido à maior exposição a predação e mudanças microclimáticas (Forman, 1986), porém é importante destacar que os acessos, geralmente, são fontes de distúrbios na paisagem como a propagação de fogo, poluentes, porta de entrada para espécies generalistas, etc. Na área de pesquisa, o Rio Mogi-Guaçu apresenta diferentes larguras, variando de 10 a 60 metros, aproximadamente, e entre as margens mais afastadas observa-se ilhas fluviais florestadas que podem ter a função de trampolins (stepstones) para algumas espécies ou mesmo como habitat para outras.

Prevalecem os usos e coberturas de origem antrópica, com destaque para a classe "pasto" que ocupa $23,4 \%$ do total da área da paisagem. As atividades agrícolas somam 15,74\%, exluindo-se as culturas de café abandonados. As classes da categoria natural preenchem $48,67 \%$ da paisagem, com predomínio da Floresta Estacional Semidecidual em estágio intermediário de sucessão (22,16\%). (Gráfico 1) 


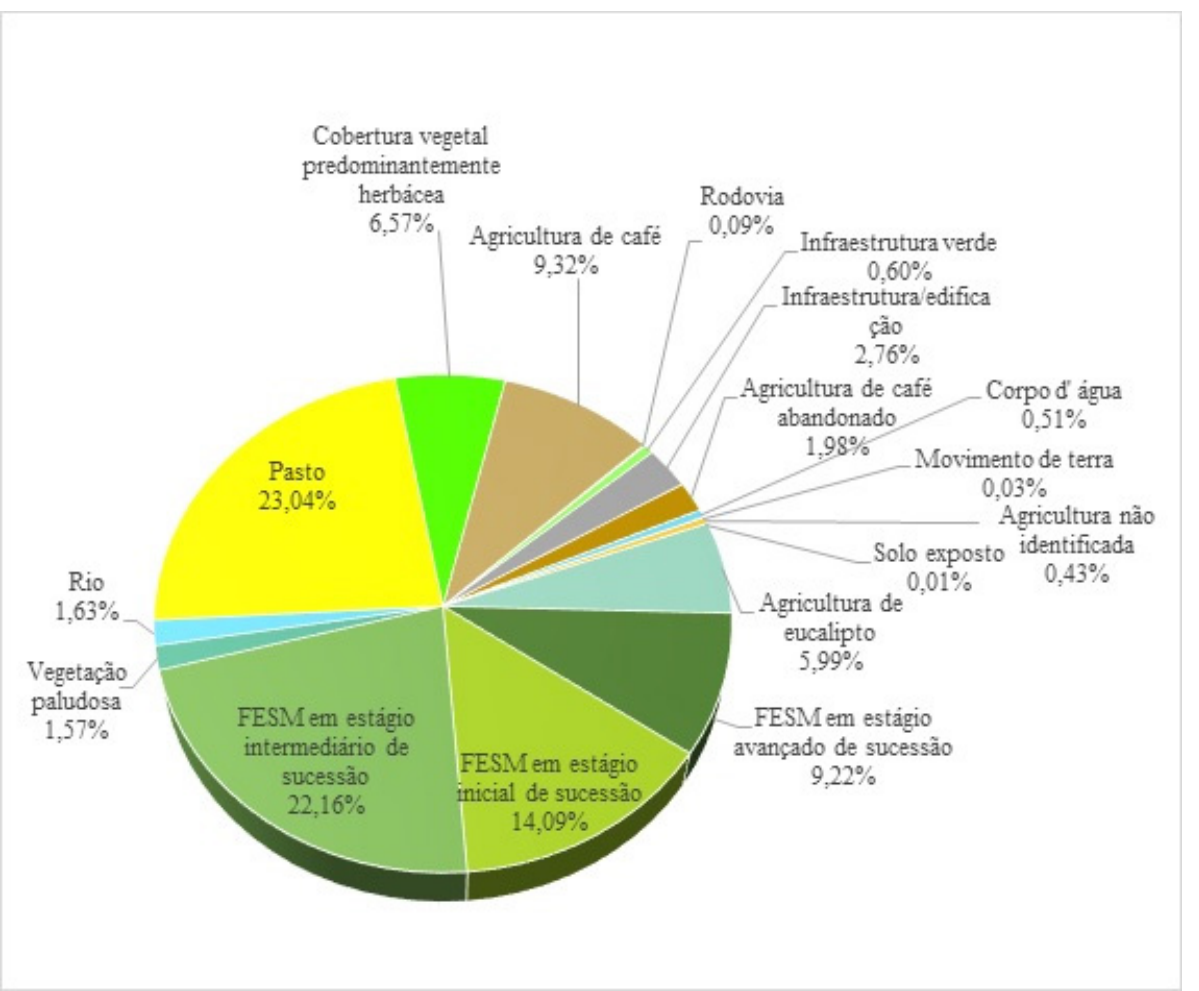

Gráfico 1 - Distribuição proporcional das classes de uso e cobertura da terra. Observa-se que os remanescentes da cobertura florestal nativa representam 45,47\% na área estudada. Fonte: Mapeamento do Uso e Cobertura da Terra, escala 1:5.000, 2018. Elaboração: Giorgia Limnios, 2018.

A caracterização da matriz paisagística foi definida pelo grau de continuidade da maior mancha, pois nenhuma classe da paisagem estudada ocupa mais de 50\% de área, que seria o primeiro critério para o estabelecimento da matriz. A partir dos resultados do índice de mancha maior (LPI) observa-se que a maior mancha da classe pasto ocupa 19,93\% do total. Ainda na categoria cultural, a maiores manchas de cada classe correspondem às atividades agrícolas de café e eucalipto, com percentuais de 3,10\% e 2,80\% do total. Na categoria natural, a maior mancha corresponde à FES em estágio intermediário de sucessão e ocupa 4,41\% da paisagem (Tabela 2 e Mapa 7) 


\begin{tabular}{|c|c|}
\hline Uso e Cobertura da Terra & LPI (\%) \\
\hline \multicolumn{2}{|l|}{ Cultural } \\
\hline Agricultura de café & 3,10 \\
\hline Agricultura de café abandonado & 0,87 \\
\hline Agricultura de eucalipto & 2,80 \\
\hline Agricultura não identificada & 0,1 \\
\hline $\begin{array}{l}\text { Cobertura vegetal predominantemente herbá- } \\
\text { cea }\end{array}$ & 0,85 \\
\hline Corpo d' água & 0,12 \\
\hline Infraestrutura verde & 0,09 \\
\hline Infraestrutura/edificação & 0,49 \\
\hline Movimento de terra & 0,02 \\
\hline Pasto & 16,70 \\
\hline Rodovia & 0,09 \\
\hline Solo exposto & 0,01 \\
\hline \multicolumn{2}{|l|}{ Natural } \\
\hline FES em estágio inicial de sucessão & 4,61 \\
\hline FES em estágio intermediário de sucessão & 4,41 \\
\hline FES em estágio avançado de sucessão & 1,83 \\
\hline Vegetação paludosa & 0,86 \\
\hline Rio & 1,23 \\
\hline
\end{tabular}

Tabela 2 - Dados da Métrica 3 - Índice da mancha maior (LPI) - Heterogeneidade. Fonte: Giorgia Limnios, 2018. 


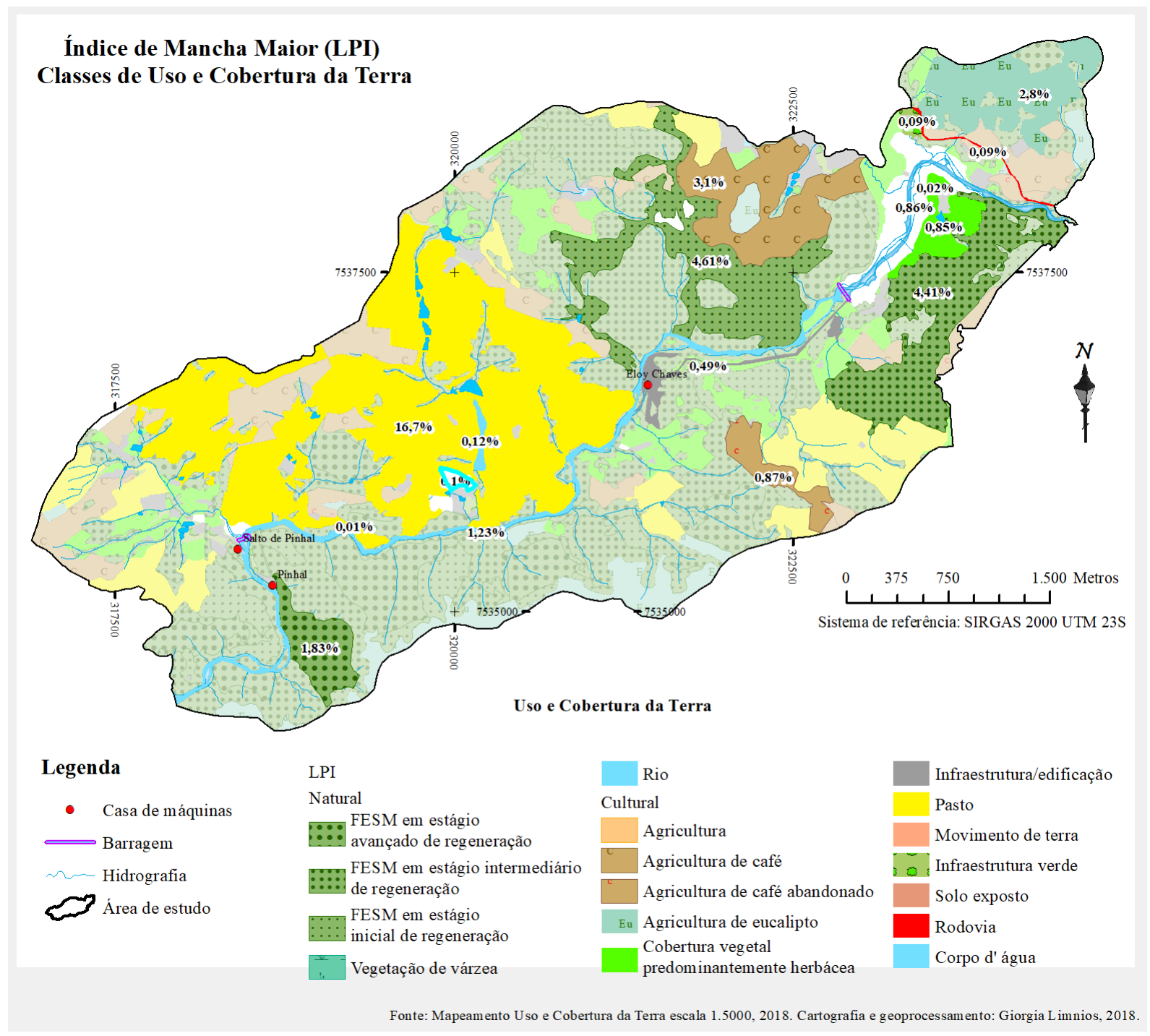

Mapa 7 - Representação espacial da Métrica 3 - Índice da mancha maior (LPI) Heterogeienidade.

O isolamento de um fragmento de cobertura vegetal natural pode ser avaliado pela métrica da distância do vizinho mais próximo da mesma classe. O cálculo foi efetuado na extensão V-LATE para Arcgis, considerando menor afastamento em linha reta entre uma mancha e seu vizinho (distância euclidiana). No mapa, observa-se que quase $78,10 \%$ dos fragmentos (157 de 201 manchas) apresentam distâncias máximas de 100 metros do seu vizinho mais próximo. Desse total 85 fragmentos correspondem ao FES em estágio inicial, 61 ao estágio intermediário e 11 ao estágio avançado. As maiores distâncias entre os vizinhos de mesma classe superam $1 \mathrm{~km}$ e correspondem a dois fragmentos de cobertura em estágio avançado de sucessão. $\mathrm{O}$ mais isolado está localizado no setor NE da área de estudo, distante 1.558,40 metros, e está 
parcialmente envolvido pela agricultura de eucalipto. Se for considerada toda a vegetação, sem distinção do estágio sucessional, como uma única classe de cobertura 92,7\% dos fragmentos apresentam distâncias inferiores a 100 metros em relação ao vizinho, e o mais isolado está distante 353,57 metros. As menores distâncias podem representar potenciais de conexão para o movimento de algumas espécies, dependendo das características do ambiente circundante, como a existência ou não de barreiras (naturais ou artificiais) e grau de artificialidade. (Mapa 8)

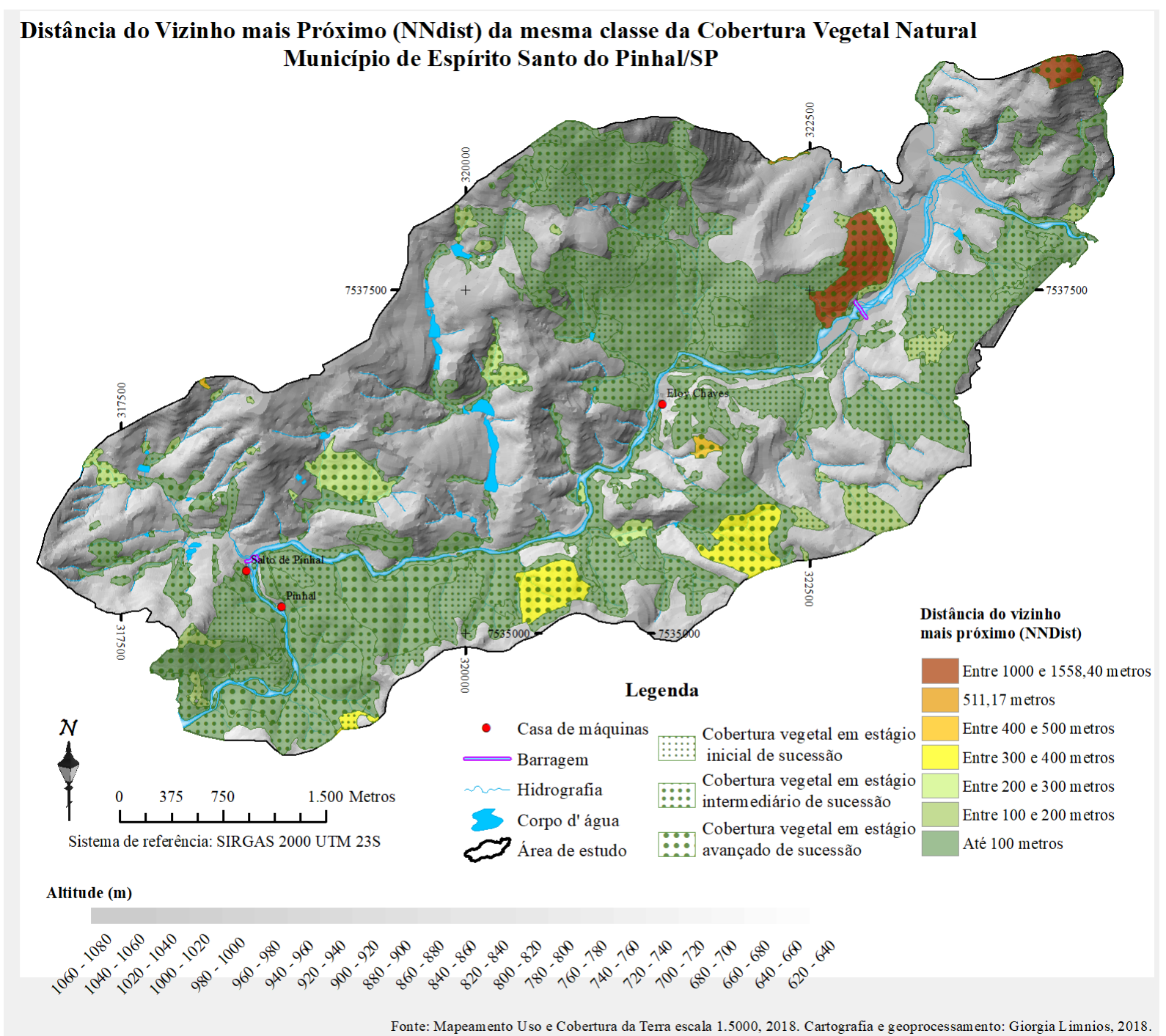

Mapa 8 - Representação espacial da Métrica 4 - Distância ao vizinho mais próximo (NNDIST) - Análise de vizinhança

O cálculo do Índice Médio da Forma (MSI) para os fragmentos de vegetação foi realizado na extensão Patch Analyst para o Arcgis. Os índices variam de 1,03 a 4,65 em uma escala da forma mais circular (valores mais próximos a 1) à forma mais alongada (valores mais distantes de 1). A maior parte dos fragmentos apresenta índices mais próximos a 1 e correspondem, principalmente, à cobertura vegetal florestal em estágio inicial de sucessão, com área máxima de 10 ha, localizados na margem direita do Rio Mogi-Guaçu. (Mapa 9) 


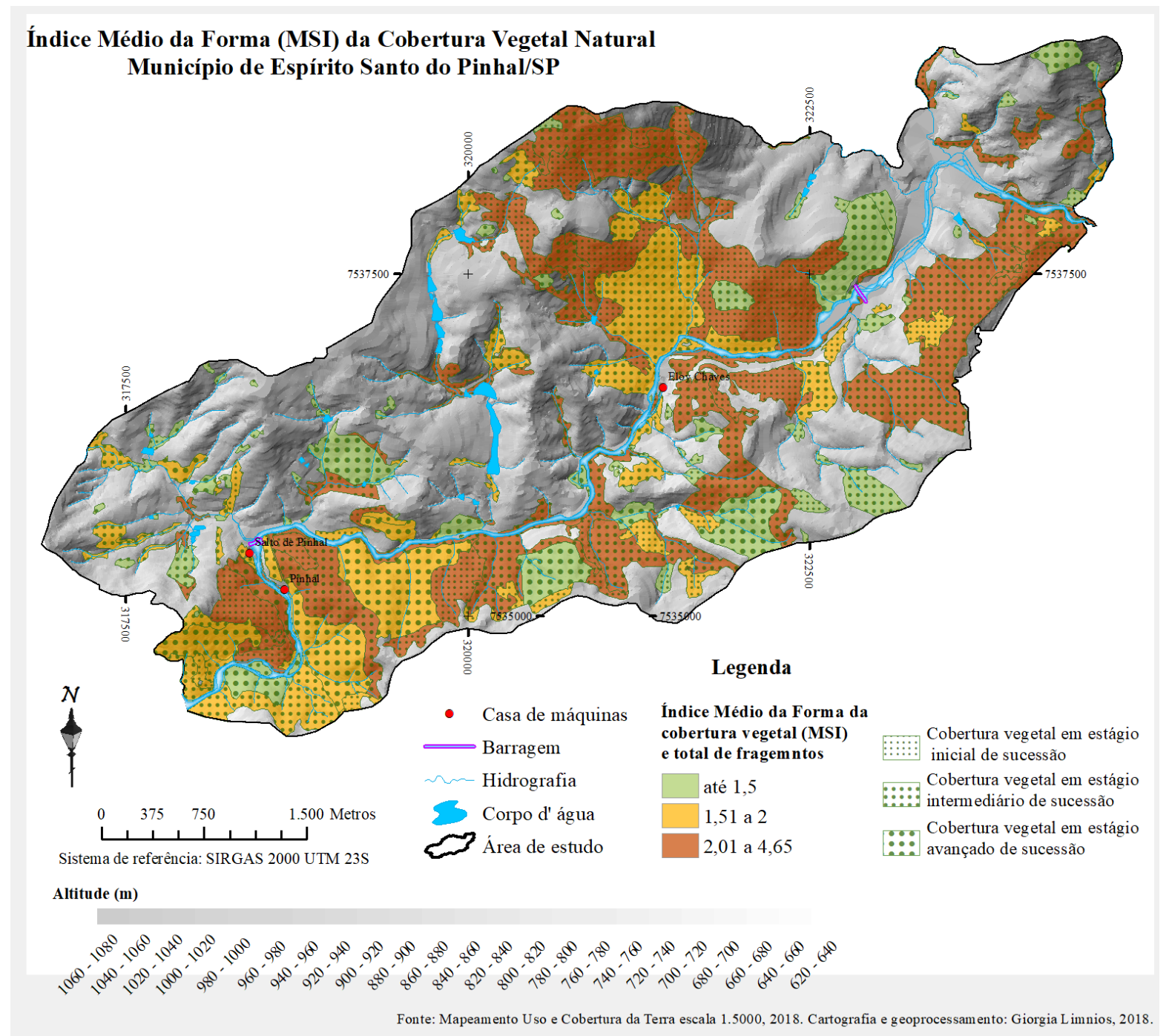

Mapa 9 - Representação espacial da Métrica 5 - Índice Médio da Forma (MSI) Análise das formas

Dentro dos valores mais baixos (até 1,5), existe 5 fragmentos de cobertura vegetal mais desenvolvida, que apresentam áreas superiores a 10 ha. Os valores intermediários correspondem principalmente aos fragmentos de estágios intermediário e avançado de sucessão florestal. De forma geral, os fragmentos que apresentam formas mais arredondadas são pequenos e estão localizados na margem direita do rio Mogi-Guaçu e, na margem oposta, localizam-se os maiores fragmentos, mais desenvolvidos, com índices de forma mais altos. Se o objetivo é preservar fragmentos com área núcleo, os índices próximos do valor 1 são mais apropriados, considerando também o tamanho da mancha. Se o objetivo é o estabelecimento de corredores, os índices mais distantes de 1 podem ser mais interessantes nesse aspecto.

O cálculo da métrica de área núcleo remanescente (área efetiva do habitat) dos fragmentos da Floresta Estacional Semidecidual foi realizado na extensão V-LATE para o Arcgis, 
considerando o tamanho de borda de 30 metros. Essa formação vegetacional apresenta 201 manchas (NP) que ocupam área (CA) de 945,11 ha, conforme dados informados na Tabela 2.

Após o processamento da métrica, a área núcleo total (TCA) é de 452,52 ha, resultado da predominância de pequenas manchas de vegetação e pela forma alongada de alguns fragmentos. A influência da forma e da área nos resultados pode ser avaliado também pelo número de áreas núcleo disjuntas, ou seja, um único fragmento pode apresentar mais de uma área efetiva de habitat (NCA $>$ NP). No recorte paisagístico temos 201 fragmentos que possuem 34 áreas núcleo disjuntas, ou seja, um único fragmento pode conter 1 ou mais áreas núcleo; além de existir 97 manchas sem habitat interno. Na tabela 2 a seguir são apresentados os resultados para todas as classes da Floresta Estacional Semidecidual.

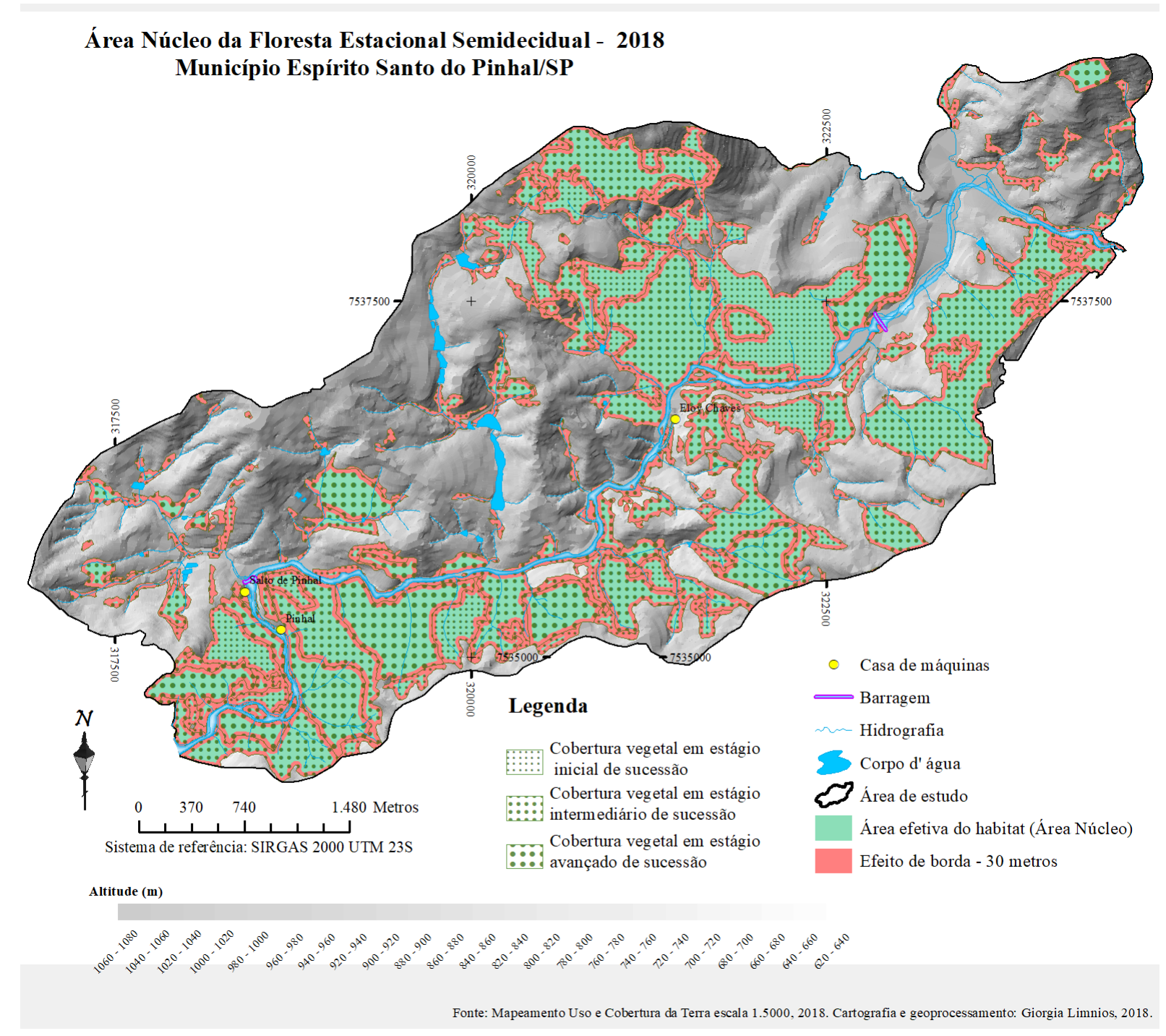

Mapa 10 - Representação espacial da Métrica 6 - Área Núcleo Remanescente (TCA/TCCA) 


\begin{tabular}{|l|c|c|c||c|c|c|}
\hline \multicolumn{1}{|c|}{ Classe } & $\begin{array}{c}\text { Sem área } \\
\text { núcleo }\end{array}$ & NP & NCA & CA & $\begin{array}{c}\text { TCCA } \\
(\mathbf{m} 2)\end{array}$ & $\begin{array}{c}\text { CAI } \\
(\mathbf{\%})\end{array}$ \\
\hline $\begin{array}{l}\text { FESM em estágio avançado de } \\
\text { sucessão }\end{array}$ & 3 & 19 & 21 & 191,64 & 119,39 & 62,30 \\
\hline $\begin{array}{l}\text { FESM em estágio intermediário de } \\
\text { sucessão }\end{array}$ & 35 & 76 & 105 & 459,90 & 231,90 & 50,42 \\
\hline $\begin{array}{l}\text { FESM em estágio inicial de suces- } \\
\text { são }\end{array}$ & 60 & 106 & 147 & 293,57 & 101,23 & 34,48 \\
\hline Total & 97 & 201 & 273 & 945,11 & 452,52 & - \\
\hline
\end{tabular}

Tabela 2 - Classes da FES e respectivos NP $=$ Número de fragmentos / (NCA) = Número de Áreas Core $/ \mathrm{CA}=$ Área da classe $/(\mathrm{TCCA})=$ Total de Área Core da Classe $\mathrm{em} \mathrm{m}^{2} /(\mathrm{CAI})=$ Índice de Área em $\%$

Apesar do baixo número de fragmentos (NP) e menor área ocupada (CA), podemos verificar que o melhor índice de área núcleo (CAI) refere-se à floresta em estágio avançado de sucessão, com percentual de $62,30 \%$, pois essa classe apresenta os melhores valores de forma (MSI) e tamanho médio aproximado do fragmento em torno de 10 ha, que resulta em um baixo número de áreas disjuntas e áreas sem habitat. Opostamente, com a mais baixa porcentagem de área núcleo (34,48\%), a cobertura vegetal em estágio inicial apresenta, em geral, o maior número de fragmentos com menores áreas, tamanho médio de 2,77 ha, que influencia na maior quantidade de manchas sem áreas núcleo. Essa classe também apresenta o maior total de áreas disjuntas devido à influência da forma nesse resultado.

\section{Resultados de todas as métricas agrupadas}

Os resultados das métricas da paisagem são importantes indicativos dos fragmentos ecologicamente e ambientalmente mais expressivos na proteção do patrimônio paisagístico.

A seleção dos fragmentos mais significativos obedeceu aos seguintes critérios para Estágio sucessional, Área, Área remanescente, Forma e Vizinhança:

- Estágio Sucessional: Seleção das coberturas em estágio avançado e intermediário de sucessão - Todos os estágios sucessionais da vegetação são importantes para a proteção, porém as florestas estruturalmente mais desenvolvidas apresentam funções ecossistêmicas, sociais e ambientais relevantes. Esse filtro seleciona 95 fragmentos da área de estudo.

- Área (CA): Fragmentos com áreas superiores a 3 ha - Nos modelos de conservação 
é preferível áreas grandes a pequenas. As maiores áreas tendem a apresentar taxas de extinção menores, maior riqueza, maior continuidade na paisagem, maior quantidade de recursos e menor efeito de borda. Os tamanhos mínimos variam de acordo com a espécie estudada, e aqui adotamos o tamanho de 3 ha, pela possibilidade de proteger manchas que contenham área núcleo de, pelo menos, 1 ha. Além disso, há baixa representatividade de fragmentos acima desse tamanho. A aplicação desse filtro sobre as classes anteriormente mencionadas seleciona 44 fragmentos do FESM.

- Área remanescente (TCCA): Fragmentos com área remanescente superior a 1 ha. A aplicação desse filtro seleciona 55 fragmentos, do total de 126 áreas remanescentes.

- Forma (MSI): Melhores índices de forma $\leq 2-$ A adoção de índices mais baixos ou mais altos depende dos objetivos de proteção das coberturas vegetais. Nos modelos de conservação é preferível formas mais circulares a formas mais alongadas em virtude do menor efeito de borda, assim foi adotado o valor 2 como índice máximo. Esse filtro seleciona 34 , do total de 44 fragmentos.

- Vizinhança (NNdist): Menores distâncias do vizinho mais próximo da mesma classe até 100 metros. Quanto menores forem as distâncias entre os fragmentos de mesma classe, maior será a permeabilidade das espécies na paisagem e maior possibilidade de estabelecer conexão entre as manchas por meio de ações de restauração ou recuperação, desde que não haja barreiras efetivas. Esse filtro seleciona 40, do total de 44 fragmentos.

Os critérios Estagio de sucessão e Área (CA) selecionam conjuntamente 44 fragmentos e esse total foi a base para a observação dos demais critérios. Cada mancha pode apresentar entre 2 e 5 resultados de métricas e quanto for a quantidade de resultados, dentro dos filtros estabelecidos, mais relevante é para a proteção. No mapa 11, podemos verificar as manchas que reúnem a maior quantidade de medidas da paisagem, sendo estas a mais relevantes para a proteção. 


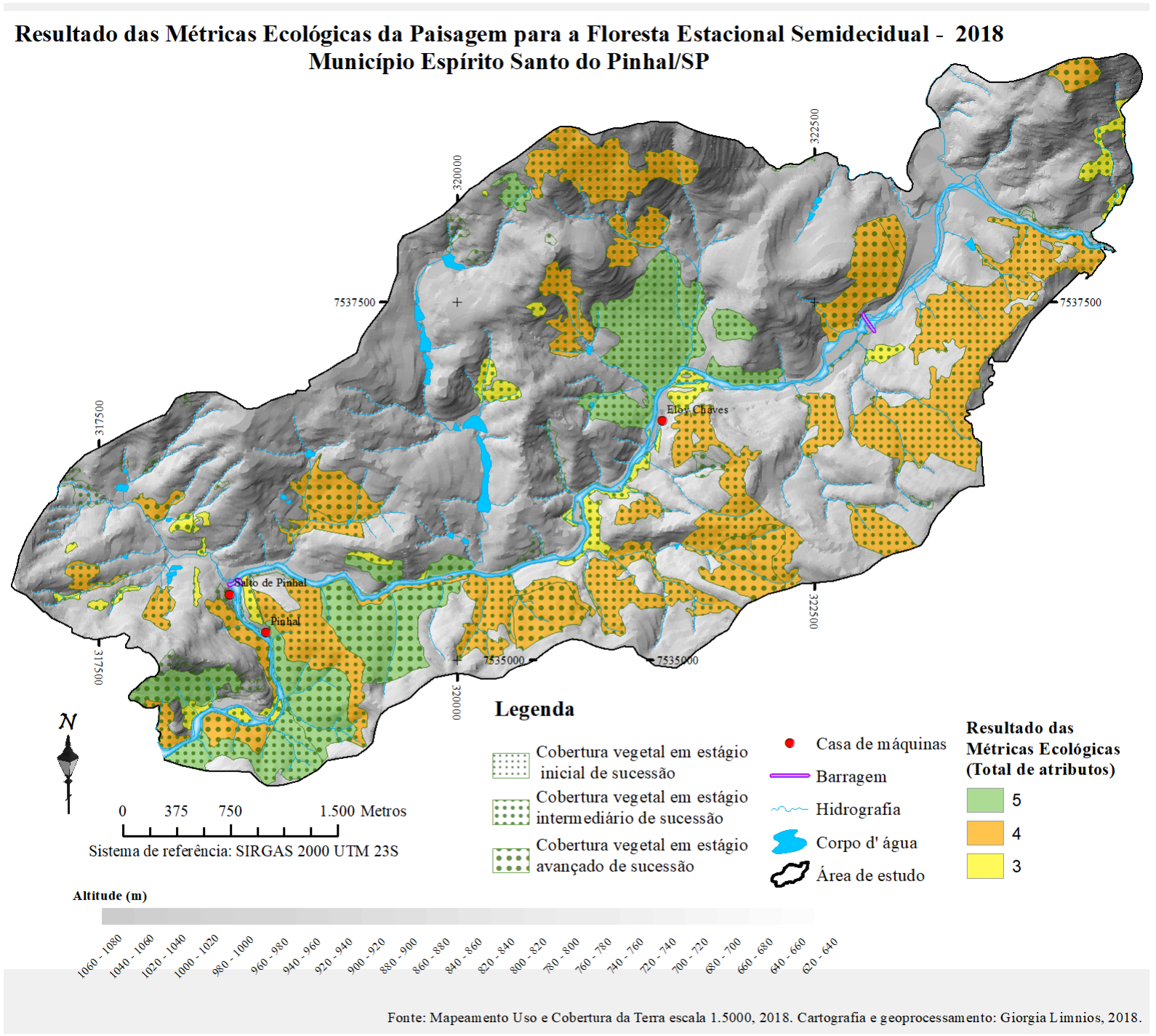

Mapa 11 - Resultado das métricas agrupadas. Fonte: Uso e cobertura da terra, 2018. Cartografia e Geoprocessamento: Giorgia Limnios, 2018.

\section{Visibilidade/Fruição}

Pensar na visibilidade do bem protegido na paisagem significa destacá-lo e possibilitar o aproveitamento visual a diversas distâncias e direções por maior número de pessoas. A localização e o tipo de entorno do ponto de observação influem muito nesse aspecto, podendo apreciar panoramas mais ou menos amplos. Observar em locais os fundos de vale de ambientes com relevo dissecado, a distância visual fica mais restrita, assim como nas áreas urbanas com edificações muito altas. Os mapas 12 e 13 mostram duas situações de visibilidade da paisagem, a partir da casa de máquinas ${ }^{1}$ e a partir da barragem ${ }^{2}$. As linhas representam o alcance da vi1 Considerado a altura de $1,70 \mathrm{~m}$

2 Considerado a altura de 20 metros. 
são da linha do horizonte e para esse cálculo foi considerada a obstrução pelos fragmentos de vegetação, pela altura média de 4 metros para os estágios iniciais de sucessão, 7 metros para o estágio intermediário de sucessão e 12 metros para o estágio avançado. As áreas visíveis no terreno estão representadas pela cor laranja e não consideram as barreiras de vegetação.

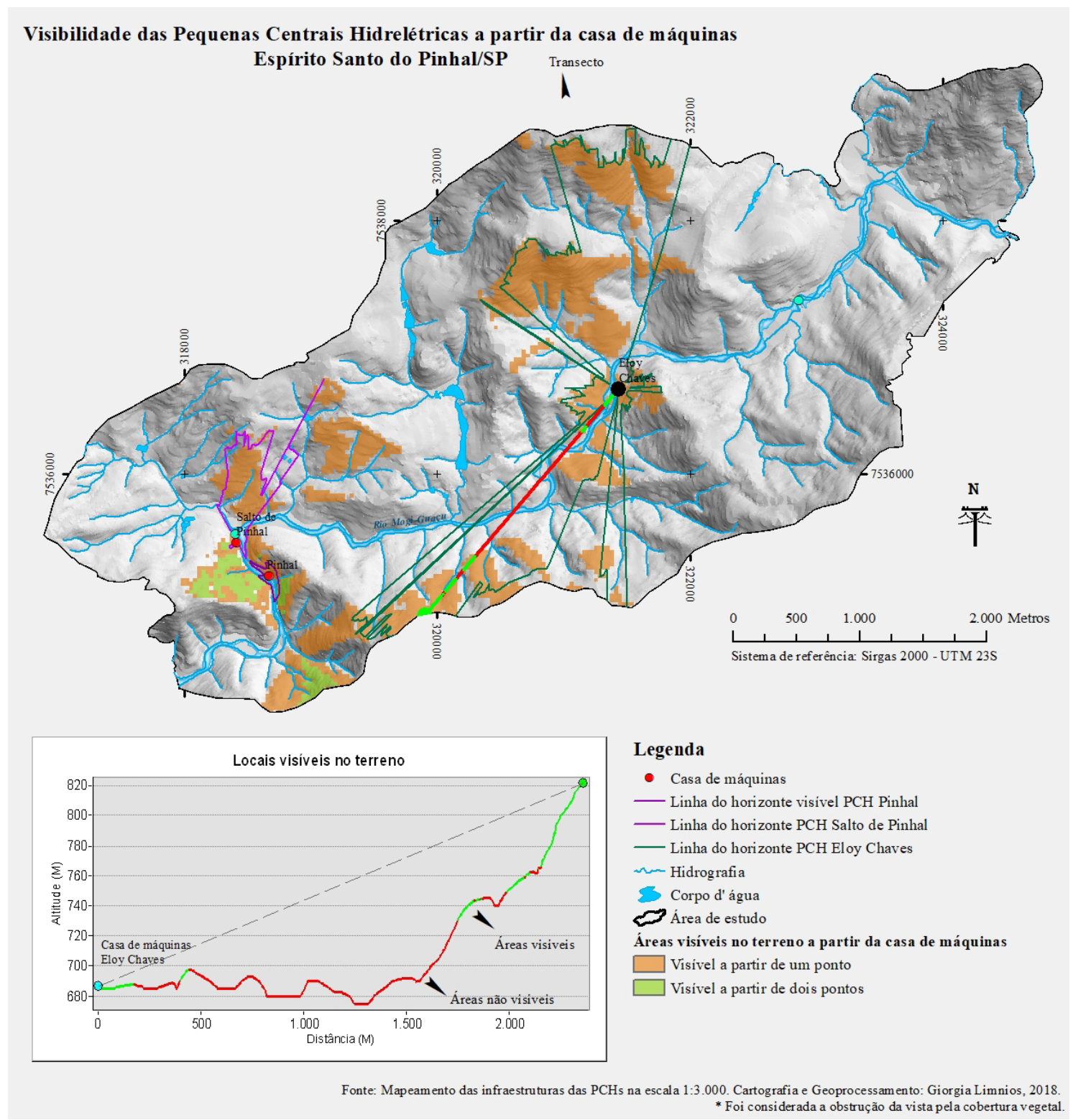

Mapa 12. Visibilidade a partir da casa de máquinas. Cartografia e Geoprocessamento: Giorgia Limnios, 2018. 


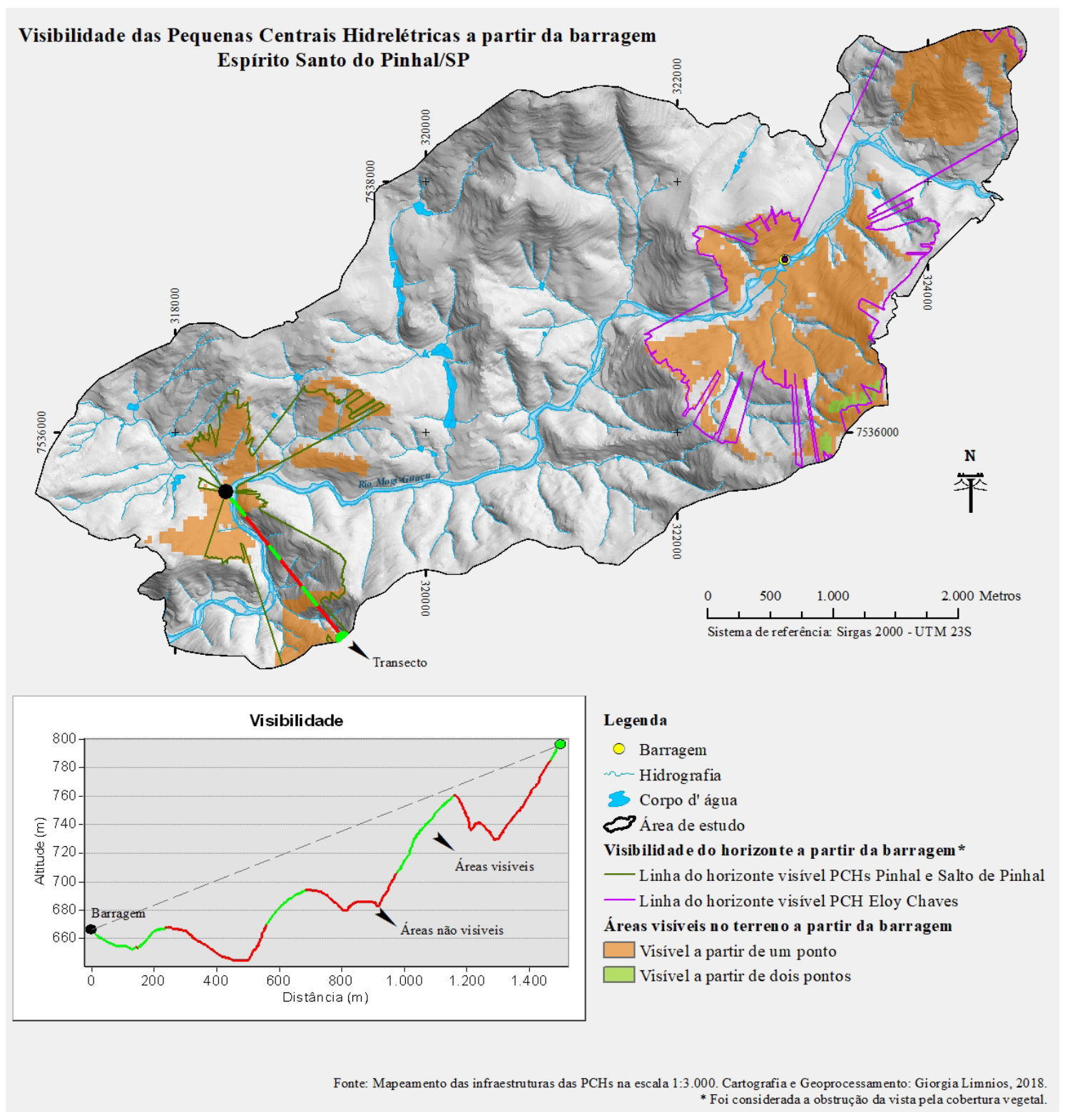

Mapa 13. Visibilidade a partir da barragem. Cartografia e Geoprocessamento: Giorgia Limnios, 2018.

A partir dos pontos especificados pode-se ter visibilidade da paisagem a distâncias, aproximadas, de até 2.800 metros, envolvendo os contornos do horizonte e as encostas médias e superiores dos terrenos. A casa de máquinas da PCH Salto de Pinhal possui o menor campo visual, devido à proximidade de vertentes mais inclinadas e próximas ao leito do rio e pela presença da cobertura vegetal mais desenvolvida do entorno; enquanto a usina de Eloy Chaves tem a maior dimensão de afastamento. A vista a partir das barragens apresenta maior abrangência visual, em especial a PCH Eloy Chaves, que possui barragem de 21 metros de altura. Importante salientar esses são exemplos de visibilidade de pontos bem específicos das PCHs, e qualquer outro local irá apresentar contornos e distâncias visuais distintas, mais ou menos amplas. 
Os limites do patrimônio foram definidos considerando os resultados das medidas ecológicas e visuais, a legislação das áreas de preservação permanente hídricas, limites culturais (acessos) e topos de morro, envolvendo as três PCHs.

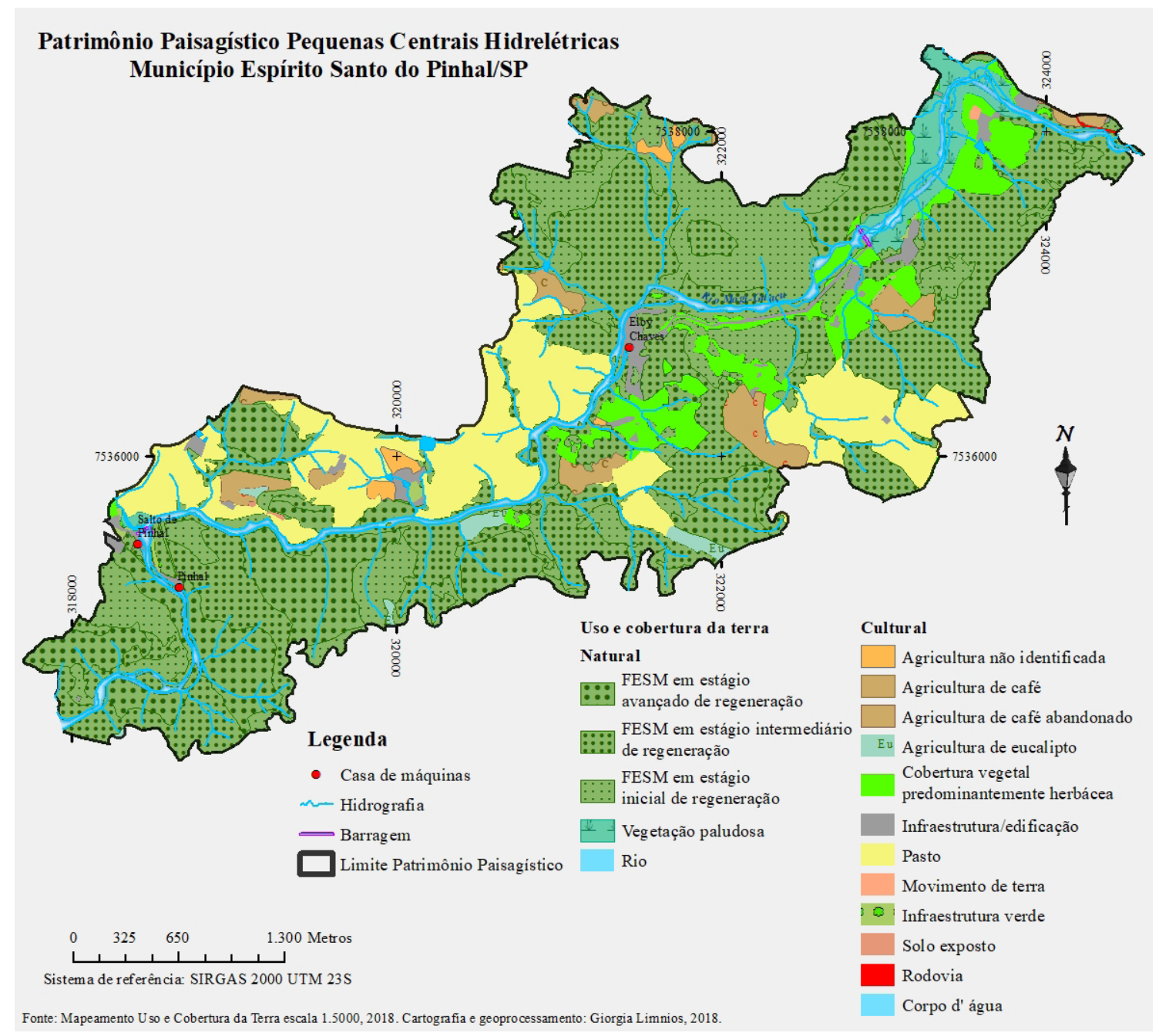

Mapa 14. Limite do patrimônio paisagístico e usos e coberturas da terra incluídos. Cartografia e Geoprocessamento: Giorgia Limnios, 2018. 


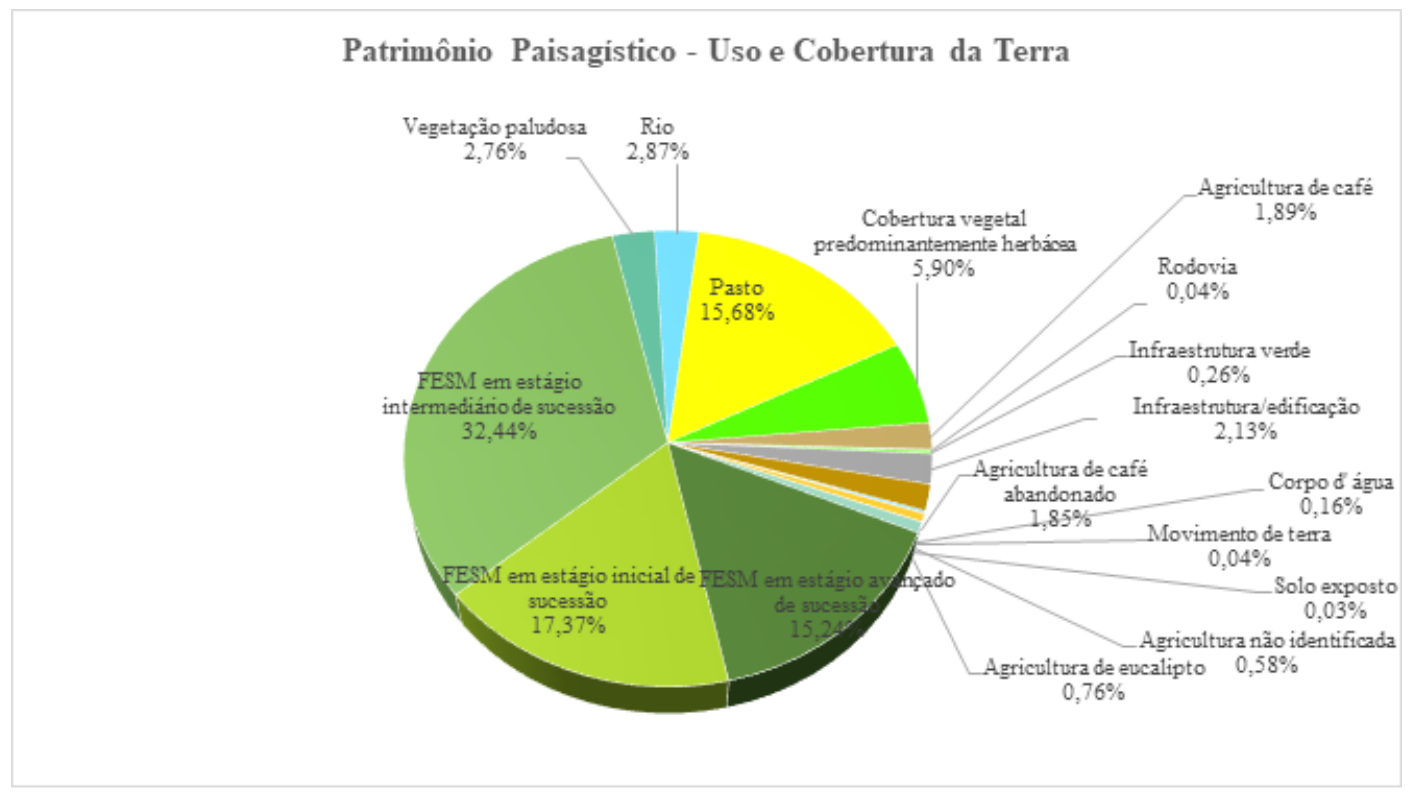

Grafico 2. Percentual das classes de uso e cobertura da terra do patrimônio paisagístico. Org. Giorgia Limnios, 2018.

\section{Considerações finais}

O delineamento da paisagem industrial das pequenas centrais hidrelétricas, localizadas na área rural do município de Espirito Santo do Pinhal, considerando os parâmetros ecológicos e visibilidade do local, permite conhecer e incluir os fragmentos florestais ecologicamente mais relevantes na proteção patrimonial. Essa proposta também considera os atributos geoecológicos e históricos que constituem essa paisagem, rompendo com a dicotomia natural/ cultural e com a visão isolada de proteção das edificações estruturas. Valoriza uma escala que pode ser percebida pela sociedade como um conjunto.

A matriz paisagística é composta pelos remanescentes da Floresta Estacional Semidecidual, protetora das águas, dos solos, do relevo e da vida que existe e acontece nessa paisagem, recobrindo $65,05 \%$ da área total da paisagem. Os demais usos e coberturas da terra foram abrangidos parcialmente com intuito de proteger cursos d'água e nascentes.

Essa proposta desenho paisagístico protege:

- História, memória, tecnologia e arquitetura da Pequena Central Hidrelétrica Salto do Pinhal, de 1911. 
- História, memória, tecnologia e arquitetura da Pequena Central Hidrelétrica Pinhal, de 1928.

- História, memória, tecnologia e arquitetura da Pequena Central Hidrelétrica Eloy Chaves, de 1954;

- 91 nascentes e respectivas Áreas de Preservação Permanente (raio de 50 metros),

- Integralmente 22 sub-bacias hidrográficas da margem esquerda do Rio Mogi-Guaçu e suas encostas, além das Áreas de Preservação Permanente hídricas de 30 metros;

- Integralmente 12 sub-bacias hidrográficas da margem direita do Rio Mogi-Guaçu e suas encostas e, parcialmente, outras 6 sub-bacias; além das Áreas de Preservação Permanente hídricas de 30 metros;

- Área de preservação permanente de 100 metros do Rio Mogi-Guaçu;

- 8 ilhas fluviais florestadas;

- Visibilidade/fruição;

- 10 Corpos d'água;

- 16 fragmentos da Floresta Estacional Semidecidual em estágio avançado de sucessão, com área de 180,64 ha e suas funções ecossistêmicas;

- 64 fragmentos da Floresta Estacional Semidecidual em estágio inicial de sucessão com 205,93 ha e suas funções ecossistêmicas;

- 56 fragmentos da Floresta Estacional Semidecidual em estágio intermediário de sucessão 384,56 e suas funções ecossistêmicas;

- 3 áreas de vegetação paludosa existente nas proximidades das represas;

- Agricultura de café e eucalipto, áreas de pasto,

O instrumento de proteção mais adequado à paisagem industrial hidrelétrica é a chancela da paisagem, pois esse instrumento considera as interações existentes entre a cultura e o meio natural e determina que a gestão seja realizada com a colaboração do poder público, sociedade civil e iniciativa privada. Para evitar descaracterizações das edificações das PCHs, estas podem ser protegidas pelo instrumento de tombamento mantendo os usos para fins operacionais ou educativos. A usina Salto de Pinhal está com as atividades operacionais paralisadas, mas pode ser reativada com funções educativas.

As pequenas centrais hidrelétricas são patrimônios que mantém estruturas, objetos, máquinas, equipamentos, edificações bem marcadas no tempo e na paisagem. É também um 
patrimônio das técnicas das engenharias e dos saberes técnicos transmitidos, que se modificam no tempo e mantém a história e a memória da eletricidade. 
Bibliografia

1. AB' SABER, AZIZ NACIB. A Geomorfologia do Estado de São Paulo. In: Conselho Nacional de Geografia (Brasil). Aspectos geográficos da Terra Bandeirantes. Rio de Janeiro, IBGE, 1954, p. 1-97.

2. AB' SABER, AZIZ NACIB. Notas sobre o Povoamento e a Geografia Urbana do Sudoeste de Goiás. Anuário da Faculdade de Filosofia, "Sedes Sapientiae" da Pontifícia Universidade Católica de São Paulo, São Paulo, v. 9, p. 97-110, 1951-1952.

3. AB' SABER, AZIZ NACIB. O Chão, o Clima e as Águas. In: FREITAS, M. J. V.; PIMENTEL, O. (Ed.). São Paulo: espírito, povo, instituições. São Paulo: Pioneira, 1968. p. $13-27$

4. AB' SABER, AZIZ NACIB. Potencialidades Paisagísticas Brasileiras. In: Recursos Naturais, Meio Ambiente e Poluição: Contribuição de um ciclo de debates. Rio de Janeiro, FIBGESUPREN, v. 1, p. 19-38, 1977.

5. AB' SABER, AZIZ NACIB. O tombamento da Serra do Mar. In: Revista do Patrimônio Histórico e Artístico Nacional. N 21, 1986. p. 7-20.

6. AB'SABER, AZIZ NACIB. Os domínios de natureza no Brasil: potencialidades paisagísticas. São Paulo: Ateliê Editorial, 2003.

7. ALVES, ALEXANDRE FERREIRA DE ASSUMPÇÃO. O Tombamento como instrumento de proteção ao patrimônio cultural. Disponível em https://pos.direito.ufmg.br/ rbep/index.php/rbep/article/download/69/67.

8. AMARAL, CRISTIANO E PRADO, FERNANDO AMARAL (ORGS.). Pequenas Centrais Hidrelétricas no Estado de São Paulo. São Paulo: Páginas \& Letras, 2004.

9. ARECES, MIGUEL ÁNGEL ÁLVAREZ. La herencia cultural y industrial en el paisaje: Patrimonio Industrial, Paisaje y Territorios Inteligentes. Labor \& Engenho, Campinas [Brasil], v.4, n.1, p.78-100, 2010. Disponível em: <www.conpadre.org $>$ e $<$ www.labore. fec.unicamp.br>.

10. BERQUE, AUGUSTIN. Paisagem marca, paisagem matriz: elementos da problemática para uma geografia cultural. In: CORREAA, ROBERTO LOBATO e ROSENDAHL, ZENY (Orgs). Paisagem, Tempo e Cultura. Rio de janeiro: Editora UERJ, 1998.

11. BERQUE, AUGUSTIN. Milieu, trajet de paysage et déterminisme géographique. Espace géographique. Tome 14 n², 1985. p. 99-104.

12. BESSE, Jean-Marc. Ver a Terra: seis ensaios sobre a paisagem e a geografia. São Paulo: Perspectiva, 2006. 
13. BESSE, Jean-Marc. Las cinco puertas del paisaje: ensayo de uma cartografía de las problemáticas paisajeras contemporâneas. In: MADERUELO, J. "Paisaje y Pensamiento". Serie: $\mathrm{H}^{\mathrm{a}}$ del Arte y de la Arquitectura, ABADA Editores. Madrid, España. 2006.

14. BRASIL. Decreto-lei n $^{0}$ 25, de 30 de novembro de 1937. Lex: coletânea de legislação: edição federal, São Paulo, v. 7, 1943. Suplemento.

15. BROSSARD, THIERRY; WIEBER, JEAN-CLAUDE. Le paysage: trois définitions, un mode d'analyse et de cartographie. Espace géographique. Tome 13 n¹, 1984. pp. 5-12.

16. BROWN, JAMES; LOMOLINO, MARK V. Biogeografia. Ribeirão Preto: FUNPEC, 2006.

17. CANCLINI, NÉSTOR GARCÍA. O Patrimônio cultural e a construção imaginária do nacional. Brasília: Revista Patrimônio Histórico e Artístico Nacional, nº 23, 1994. p. 95 111

18. CETESB. Qualidade das águas interiores no estado de São Paulo 2016. [recurso eletrônico] / CETESB. - - São Paulo: CETESB, 2017.

19. COSTA, JOSÉ PEDRO DE OLIVEIRA. Patrimônio natural e estatuto do tombamento: reflexões sobre a estratégia de preservação. In: Revista do Patrimônio Histórico e Artístico Nacional. N 21, 1986. p. 21-25

20. CHOAY, FRANÇOISE. A Alegoria do Patrimônio. Lisboa: Edições 70, 2000.

21. CHOUQUER, GÉRARD. Nature, environnement et paysage au carrefour des theories. Études rurales, p. 157-158, 2001.

22. COMISSÃO GEOGRÁFICA E GEOLÓGICA. Relatório de Exploração dos Rios Paranapanema e Itapetininga. Rio de Janeiro: Imprensa Oficial, 1889. Disponível em: http:// igeologico.sp.gov.br/publicacoes/relatorio-da-comissao-geografica-e-geologica/

23. COMISSÃO GEOGRÁFICA E GEOLÓGICA. Relatório de Exploração dos Rios Feio e Aguapehy. Rio de Janeiro: Imprensa Oficial, 1905. Disponível em: http://igeologico. sp.gov.br/publicacoes/relatorio-da-comissao-geografica-e-geologica/

24. COMISSÃO GEOGRÁFICA E GEOLÓGICA. Relatório de Exploração do Rio-Grande e Seus Afluentes. Rio de Janeiro: Imprensa Oficial, 1913. Disponível em: http://igeologico. sp.gov.br/publicacoes/relatorio-da-comissao-geografica-e-geologica/

25. CONDEPHAAT. Discussão preliminar sobre o tratamento do entorno das áreas naturais tombadas. São Paulo: Condephaat, 1992. Documento interno.

26. CONDEPHAAT. Processo Administrativo no 00300. São Paulo: Condephaat, 1973. Documento interno.

27. CORDEIRO, JOSÉ MANUEL LOPES. Algumas questões sobre o estudo e salvaguarda 
de paisagens industriais. Labor \& Engenho, Campinas [Brasil], v.5, n.1, p.1-12, 2011. Disponível em: <www.conpadre.org $>$ e $<$ www.labore.fec.unicamp.br $>$.

28. DEAN, WARREN. A ferro e fogo: a história da devastação da Mata Atlântica Brasileira. São Paulo: Cia. Das letras, 2007.

29. COSGROVE, DENIS. Observando la naturaleza: El paisage y el sentido europeo de la vista. Boletín de La A.G.E. n 34, 2002. pág 63-89.

30. COSGROVE, DENIS. A geografia está em todo lugar: cultura e simbolismo em paisagens humanas. In: CORREA, ROBERTO LOBATO e ROSENDAHL, ZENY (Orgs). Paisagem, Tempo e Cultura. Rio de janeiro: Editora UERJ, 1998.

31. DUBOST, FRANÇOISE. Um noveau patrimoine, le végétal. In: Patrimoine et passions identitaires: Entretiens du Patrimoine, Théâtre National de Chaillot, Paris, 6, 7 et 8 jan 1997 / sous la présidence de Jacques Le Goff. Paris: Fayard, 1998 : Éd. du Patrimoine. $445 \mathrm{p}$.

32. ELLOVICTCH, MAURO DA FONSECA; VALERA, CARLOS ALBERTO. Manual Novo Código Florestal. Belo Horizonte: CEAF, 2013.

33. FERREIRA, CAMILA CORSI. Arquitetura Residencial Urbana Espírito Santo do Pinhal, 1880-1930. Dissertação de Mestrado. São Carlos, 2010.

34. FIGUEIREDO, VANESSA GAYEGO BELLO. O patrimônio e as paisagens: novos conceitos para velhas concepções? Revista Paisagem e Ambiente: Ensaios no 32, São Paulo, 2013. p. 83 - 118

35. FIGUEIREDO, Vanessa GAYEGO BELLO. Da tutela dos monumentos à gestão sustentável das paisagens culturais complexas. TESE (Doutorado) - FAU/USP, 2014. (p. 210-227).

36. FORMAN, T.T. RICHARD; GODRON, MICHEL. Landscape Ecology. New York: Ed.Wiley \& Sons, 1985.

37. FORMAN, T.T. RICHARD. Land mosaics: the ecology of landscapes and regions. Cambridge University Press, Cambridge, 1995.

38. FORMAN, T.T. RICHARD. Some general principles of landscape and regional ecology. Landscape Ecology, vol. 10, n 3, 1995. p. 133-142

39. FUNDAÇÃO SEADE . Annuario Estatistico de São Paulo. São Paulo: 1901. viii, 815 p.

40. FUNDAÇÃO SEADE. Annuario Estatistico, de São Paulo, Brasil. Estatistica Economica e Financeira. 1920, vol. I. Disponível em http://www.seade.gov.br/produtos/bibliotecadigital.

41. FURLAN, SUELI ANEGELO. Paisagens sustentáveis: São Paulo e sua cobertura vegetal. In: CARLOS, A. F. A.; OLIVEIRA, A. U. Geografias de São Paulo: a metrópole do 
século XXI. São Paulo: Contexto, 2004.

42. GÓMEZ-MENDOZA, JOSEFINA. Del patrimonio paisaje a los paisajes patrimônio. Documents d'Anàlisi Geogràfica, vol. 59/1, 2013.

43. GOLDENSTEIN, LÉA. Subsídios para um plano sistematizador de proteção das paisagens do Estado de São Paulo. Silvicultura em S. Paulo. Revista do Instituto Florestal, São Paulo, vol.16A, parte 3, 1982. p.1530-1533

44. INSTITUDO BRASILEIRO DE GEOGRAFIA E ESTATISTICA (IBGE). Manual técnico da vegetação brasileira. Rio de Janeiro: IBGE, 2012.

45. INSTITUDO BRASILEIRO DE GEOGRAFIA E ESTATISTICA (IBGE). I Centenário das ferrovias. Rio de Janeiro: SERGRAF do IBGE, 1954.

46. INSTITUTO DO PATRIMÔNIO HISTÓRICO E ARTÍSTICO NACIONAL (IPHAN). Reflexões sobre a chancela da Paisagem Cultural Brasileira. Brasília: 2011.

47. KUHL, BEATRIZ MUGAYAR. Problemas teórico-metodológicos de preservação do Patrimônio Industrial. Seminário de Pesquisa Patrimônio: um debate multidisciplinar. FAU-Maranhão, 25 de maio de 2010.

48. LANG, STEFAN; BLASCHKE, THOMAS. Análise da paisagem com SIG. São Paulo: Oficina de Textos, 2009.

49. LANNA, ANA LÚCIA DUARTE. Meio Ambiente: patrimônio cultural da USP. São Paulo: Editora da Universidade de São Paulo/Imprensa Oficial do estado de São Paulo/ Comissão de Patrimônio Cultural, 2005.

50. LEFF, HENRIQUE. Saber ambiental: sustentabilidade, racionalidade, complexidade, poder. Petrópolis: Vozes, 2001.

51. LEITE, MARCELO (ORG.). Nos caminhos da biodiversidade paulista. São Paulo: Secretaria do Meio Ambiente: Instituto Amigos da Reserva da Biosfera da Mata Atlântica: Imprensa Oficial do Estado de São Paulo, 2007.

52. LORENZO, HELENA DE CARVALHO. Eletrificação e Crescimento Industrial no Estado de São Paulo: 1880-1940. In: Perspectivas, São Paulo, nº 17-18, 1994/1995.

53. LUSIGI, WALTER J. Managing protected areas in Africa. Paris: UNESCO, 1992. 200 p. 54. MAGALHÃES, GILDO. Força e luz: eletricidade e modernização na República Velha. São Paulo: UNESP, FAPESP, 2000.

55. MARCHESAN, ANA MARIA. O entorno dos bens tombados na legislação brasileira. Porto Alegre: Revista Magister de Direito Ambiental e Urbanístico, v. 6, n. 35, abr./maio 2011. p. 73-98

56. MARGULES, C. R.; PRESSEY, R. L. Systematic conservation planning. Nature, v.405, 
p.243-253, 2000.

57. MARSIGLIA, CECÍLIA; CIPARRONE MELLO, MARIA REGINA E ROBLES REIS BACELLAR, NELY. S.A Central Elétrica Rio Claro. São Paulo: CESP, IEB, 1986. Fascículos da História da Energia Elétrica em São Paulo - n. 1.

58. MARTinelli, MARCELO. Clima do Estado de São Paulo. Confins [Online], 8 | 2010, posto online no dia 14 Março 2010, consultado o 31 Janeiro 2016. URL: http://confins. revues.org/6348; DOI : 10.4000/confins.6348

59. MATOS, ODILON NOGUEIRA. O café e ferrovias: evolução ferroviária de São Paulo e o desenvolvimento da cultura cafeeira. São Paulo: Pontes, 1990.

60. MCGARIGAL, K., SA CUSHMAN, AND E ENE. 2012. FRAGSTATS v4: Spatial Pattern Analysis Program for Categorical and Continuous Maps. Computer software program produced by the authors at the University of Massachusetts, Amherst. Available at the following web site: http://www.umass.edu/landeco/research/fragstats/fragstats.html

61. MELO, KELLY CRISTINA. Paisagem Cultural do Rio de Janeiro: o patrimônio na valorização, gestão e ordenamento do território. Tese de Doutorado

62. MELLO E SILVA, LEONARDO. Patrimônio industrial: passado e presente. Revista Patrimônio (IPHAN): Dossiê Herança Industrial, nº 4, mar/abr 2006.

63. MENEZES, ULPIANO T. BEZERRA DE. Patrimônio industrial e política cultural. In: Anais do I Seminário Nacional de História e Energia. São Paulo, Departamento do Patrimônio Histórico, Secretaria Municipal de Cultura, 1988.

64. MENEZES, ULPIANO T. BEZERRA DE. A paisagem como fato cultural. In: YÁZIGI, Eduardo (Org.). Turismo e Paisagem. São Paulo: Contexto, 2002, p. 29-64.

65. MENESES, ULPIANO TOLEDO BEZERRA DE. A cidade como bem cultural: áreas envoltórias e outros dilemas, equívocos e alcance da preservação do patrimônio ambiental urbano. In: Patrimônio: atualizando o debate. São Paulo: 9. SPR IPHAN, 2006.

66. MENESES, ULPIANO TOLEDO BEZERRA DE. O campo do Patrimônio Cultural: uma revisão de premissas. In: Anais I Fórum Nacional do Patrimônio Cultural: Sistema Nacional de Patrimônio Cultural: desafios, estratégias e experiências para uma nova gestão. Brasília: Iphan, 2009. p.127-137

67. METZGER, JEAN PAUL. Estrutura da paisagem e fragmentação: análise bibliográfica. Anais da Academia Brasileira de Ciências, v.71, 1999. p.445-463

68. METZGER, JEAN PAUL. O que é ecologia de paisagens? Biota Neotropica, 1(1/2), 2003. p.1-9

69. METZGER, JEAN PAUL. Estrutura da paisagem: o uso adequado de métricas. Pp. 423-453. In: L. Cullen Jr.; R. Rudran \& C. Valladares-Padua (orgs.). Métodos de estudo em 
Biologia da Conservação e Manejo da Vida Silvestre. Editora UFPR e Fundação O Boticário de Proteção à Natureza, Curitiba, 2003.

70. METZGER, JEAN PAUL; CASATTI, LILIAN. Do diagnóstico à conservação da biodiversidade: o estado da arte do programa BIOTA/FAPESP. Biota Neotropica, v. $6, \mathrm{n}^{\circ}$ 2, 2006.

71. MONBEIG, PIERRE. Pioneiros e fazendeiros de São Paulo. São Paulo: HUCITEC; PÓLIS, 1984.

72. MONBEIG, PIERRE. A paisagem: espelho de uma civilização. In: Revista Geographia: Niterói, UFF, Instituto de Geociências, Programa de Pós-Graduação em Geografia, volume 6, número 11, 2004. p. 109-117.

73. MONGELLI, MONICA DE MEDEIROS. Natureza e Cultura. Práticas de preservação patrimonial no Brasil. Dissertação e Mestrado - Universidade de Brasília. Brasília, 2011.

74. MONTEIRO, CARLOS AUGUSTO de FIGUEREDO. A dinâmica climática e as chuvas no estado de São Paulo. São Paulo: USP-IG, 1973.

75. MONTEIRO, CARLOS AUGUSTO de FIGUEREDO. Geossistemas: a história de uma procura. São Paulo: Contexto, 2001. 127 p.

76. MOREIRA, NICOLAU JOAQUIM. Breves considerações sobre a história e cultura do cafeeiro e consumo de seu producto. Rio de Janeiro: Typographia do Imperial Instituto Artístico, 1873.

77. MORTATI, DEBORA MARQUES DE ALMEIDA NOGUEIRA. A implantação da hidreletricidade e o processo de ocupação do território no interior paulista (1890-1930). Campinas, 2013.Tese de Doutorado.

78. MOTTA, LIA. Entorno de bens tombados. Rio de Janeiro: IPHAN/DAF/ Copedoc, 2010. 174 p. (Série Pesquisa e Documentação do IPHAN, 4).

79. MURCIA, CAROLINA. Edge effects in fragmented forests: implications for conservation. Tree Review, v. 10, nº 2, 1995. p. 58-62,

80. NOGUEIRA, D.M.A.; ARGOLLO FERRÃO, A.M. Hidrelétricas no desenvolvimento urbano e territorial de São Paulo. Labor \& Engenho, Campinas [SP] Brasil, v.9, n.1, p.19--36, jan/mar. 2015. Disponível em: www.conpadre.org

81. PELlEGRINO, P. Pode-se Planejar a Paisagem? Paisagem e Ambiente, n. 13, p. 159179, 10 dez. 2000.

82. PICARD, JEAN FRANÇISE. Technique universelle et filières nationales, le cas de l'électrification des chemins de fer européens. Revue Sciences et Techniques en Perspective, v. 1, n¹, 1997. 
83. PRADO JUNIOR, CAIO. A cidade de São Paulo: Geografia e História. São Paulo: Editora Brasiliense, 1998.

84. PROJETO ELETROMEMÓRIA. Relatório Técnico 3 ${ }^{\mathbf{a}}$ Expedição. Período: 3/2/2014 ("Socorro", em Socorro), 4/2/2014 ("Eloy Chaves", "Pinhal”, "Salto do Pinhal”, em Espírito Santo do Pinhal), 5/2/2014 ("Santa Alice", "Rio do Peixe1", "Rio do Peixe 2", em S. José do Rio Pardo), 6/2/2014 (“Edgard de Souza”, em Santana do Parnaíba, "Rasgão”, em Bom Jesus de Pirapora).

85. PUIG, HENRI. A floresta tropical úmida. São Paulo: Editora UNESP: Imprensa Oficial do Estado de São Paulo; França: Institut de Rechérche pour le Dévelopement, 2008.

86. RABELLO, SONIA. O Estado na Preservação de Bens Culturais: o tombamento. Rio de Janeiro: IPHAN, 2009, Reedições do IPHAN.

87. RABELLO, SONIA. O tombamento. In: REZENDE, MARIA BEATRIZ; GRIECO, BETTINA; TEIXEIRA, LUCIANO; THOMPSON, ANALUCIA (Orgs.). Dicionário IPHAN de Patrimônio Cultural. Vol. 1. ed. Rio de Janeiro, Brasília: IPHAN /DAF/Copedoc, 2015. (Termo chave Tombamento). ISBN 978-85-7334-279-6

88. RIBEIRO, Rafael Winter. Paisagem Cultural e Patrimônio. Rio de Janeiro: IPHAN/COPEDOC. 2007.

89. RIZZINI, CARLOS TOLEDO. Tratado de Fitogeografia do Brasil. Rio de Janeiro: Âmbito Cultural Edições Ltda, 1997.

90. RODRIGUES, EFRAIM. Efeito de bordas em fragmentos de floresta. Cadernos da Biodiversidade, v. 1, 1998, p. 1-6

91. RODRIGUES, MARLY. Imagens do passado. A instituição do patrimônio em São Paulo (1969-1987). São Paulo: UNESP/Imprensa Oficial do Estado/ Condephaat/Fapesp, 2000. Documento eletrônico https://www.mem.com.br/team.

92. RODRIGUES, MARLY. De quem é o patrimônio? Revista do Patrimônio Histórico e Artístico Nacional, no 24, 1996. p. 195-204

93. RODRIGUES, CLEIDE. Atributos ambientais no ordenamento territorial urbano: o exemplo das planícies fluviais na metrópole de São Paulo. São Paulo: Geousp - Espaço e Tempo (Online), v. 19, n. 2, p. 325-348, ago. 2015.

94. RODRIGUES, RICARDO RIBEIRO; BONONI, V.L.R. (Orgs.) Diretrizes para conservação e restauração da biodiversidade no Estado de São Paulo. São Paulo: Instituto de Botânica, 2008. 248p.

95. ROSS, JURANDYR LUCIANO SANCHES; MOROZ, ISABEL CRISTINA. Mapa Geomorfológico do Estado de São Paulo. São Paulo: Revista do Departamento de Geografia, v. 10,1996 . p. $41-58$ 
96. RUBINO, S. O mapa do Brasil passado. Revista do Patrimônio Histórico e Artístico Nacional, Brasília, no 24, 1996. p.97-105

97. RUIZ, JOSE CASTILLO. Una aproximación a la definición teórica, material, jurídica y procedimental del entorno. Sevilha: Boletín del Instituto Andaluz del Patrimonio Histórico, Año no 3, No 10, 1995, p. 34-37

98. RUIZ, JOSE CASTILLO. El entorno de los bienes inmuebles de interés cultural. Concepto, legislación y metodologias para su delimitación, evolución histórica y situación actual. Tesis Doctoral. Granada: Universidade de Granada, 1997.

99. SAINT-HILAIRE, AUGUSTE DE. Viagem a Província de São Paulo. Belo Horizonte: Itatiaia, 1976. 229 p.

100. SALA, DANTON. Mario de Andrade e o Anteprojeto do Serviço do Patrimônio Artístico Nacional. São Paulo: Revista do Instituto de Estudos Brasileiros da Universidade de São Paulo, no 31, 1990. p. 19-26.

101. SANTOS, MILTON. A natureza do espaço: técnica e tempo, razão e emoção. São Paulo: Editora da Universidade de São Paulo, 2006.

102. SANTOS, MILTON. Metamorfoses do Espaço Habitado: fundamentos teóricos e metodológicos da geografia. São Paulo: Editora da Universidade de São Paulo, $6^{a}$ ed., 2008 .

103. SANTOS FILHO, GILDO MAGALHÃES DOS. Da usina à população na velocidade da luz: fios elétricos e desenvolvimento. Labor \& Engenho, Campinas [SP] Brasil, v.9, n.1, p.06-18, jan/mar 2015. Disponível em: www.conpadre.org

104. SANTOS, HELENA MENDES DOS; TELLES, MÁRIO FERREIRA DE PRAGMÁCIO. Livro do Tombo. In: GRIECO, BETTINA; TEIXEIRA， LUCIANO; THOMPSON, ANA LUCIA (Orgs.). Dicionário IPHAN de Patrimônio Cultural. 2. ed. rev. ampl. Rio de Janeiro, Brasília: IPHAN/DAF/Copedoc, 2016. (verbete). ISBN 9788573342994

105. SARTORELLO, RICARDO et. Al. Análise da Fragmentação da Cobertura Vegetal. Diagnóstico preliminar do meio biofísico dos parques naturais municipais: Relatório Técnico. São Paulo: Departamento de Geografia/FFLCH/USP. 2013. 27p.

106. SAUER, CARL O. A morfologia da paisagem. In: CORREAA, ROBERTO LOBATO e ROSENDAHL, ZENY (Orgs). Paisagem, Tempo e Cultura. Rio de janeiro: Editora UERJ, 1998. SCHAMA, SIMON. Paisagem e memória. São Paulo: Companhia das Letras, 1996.

107. SETUBAL, MARIA ALICE (ORG). Terra Paulista: trajetórias contemporâneas. São Paulo: CENPEC, Imprensa Oficial do Estado de São Paulo, 2008.

108. SCIFONI, SIMONE. A construção do patrimônio natural. Tese de Doutorado - De- 
partamento de Geografia da Faculdade de Filosofia, Letras e Ciências Humanas da Universidade de São Paulo. São Paulo, 2006.

109. SCIFONI, SIMONE. Os diferentes significados do patrimônio natural. Revista Diálogos, DHI/PPH/UEM, v. 10, n. 3, 2006. p. 55-78

110. SCIFONI, SIMONE. Paisagem cultural. In: GRIECO, Bettina; TEIXEIRA, Luciano; THOMPSON, Analucia (Orgs.). Dicionário IPHAN de Patrimônio Cultural. 2. ed. rev. ampl. Rio de Janeiro, Brasília: IPHAN/DAF/Copedoc, 2016. (verbete). ISBN 978-857334-299-4.

111. SILVA, WESLEY RUAS. Contribuição ao debate sobre políticas de proteção a zonas ripárias em áreas rurais no brasil: impactos do novo código florestal. Dissertação de Mestrado, UFMG, 2014.

112. STERNBER, ROLF. Perspectivas Geográficas nos Sistemas Hidroelétricos. In: Revista Brasileira de Geografia, Rio de Janeiro, vol. 52 (1), jan/mar 1990. p. 157-187.

113. THOMAS, KEITH. O homem e o mundo natural. São Paulo: Cia. das Letras, 1988.

114. TURNER, MONICA; GARDNER, R.H.; O'NEILL, R.V. Landscape ecology in theory and practice: pattern and process. New York: Springer, 2001.

115. VASCONCELOS, MARCELA CORREIA DE ARAUJO. As fragilidades e potencialidades da chancela da paisagem cultural brasileira. São Paulo: Revista CPC, n.13, nov/2011 abr. 2012. p. 51-73

116. VIANA, V. M.; PINHEIRO, L. A. F. V. Conservação da biodiversidade em fragmentos florestais. Série Técnica IPEF, v. 12, nº 32, 1998. p. 25-42 


\section{Sites consultados}

1. Arquivo Público do Estado de São Paulo - http://www.arquivoestado.sp.gov.br/site/

2. Banco de Dados Bibliográficos da USP (DEDALUS) - http://dedalus.usp.br/ $\underline{F}$ RN $=717901758$

3. Biblioteca Nacional - http://bndigital.bn.gov.br/

4. CETESB - https://cetesb.sp.gov.br/

5. CIIAGRO http://www.ciiagro.sp.gov.br/ciiagroonline/

6. CNCFlora - http://www.cncflora.jbrj.gov.br/portal/pt-br/listavermelhaCONDEPHAAT - http://condephaat.sp.gov.br/

7. CONPRESP - http://www.prefeitura.sp.gov.br/cidade/secretarias/cultura/conpresp/

8. DataGeo (Sistema Ambiental Paulista) - http://datageo.ambiente.sp.gov.br/web/guest/ inicio

9. Estações Ferroviárias do Brasil - http://www.estacoesferroviarias.com.br/

10. Revista Fapesp - http://revistapesquisa.fapesp.br/2008/06/01/ajuda-do-passado/

11. FRAGSTATS - http://www.umass.edu/landeco/research/fragstats/fragstats.html

12. Fundação de Energia e Saneamento - http://www.museudaenergia.org.br

13. Fundação SEADE - http://www.seade.gov.br/

14. Geosampa - http://geosampa.prefeitura.sp.gov.br/PaginasPublicas/_SBC.aspx

15. IBGE - http://www.ibge.gov.br/

16. Infraestrutura de Dados Espaciais Ambientais do Estado de São Paulo - http://www. idesp.sp.gov.br/Visualizador

17. IPHAN - http://portal.iphan.gov.br/

18. Ministério Meio Ambiente - ww.mma.gov.br

19. Prefeitura Espírito Santo do Pinhal - http://pinhal.sp.gov.br/site/

20. Prefeitura São Paulo (Plano Diretor Estratégico) - http://gestaourbana.prefeitura.sp. gov.br/marco-regulatorio/plano-diretor/

21. Projeto Eletromemória - http://www.eletromemoria.fflch.usp.br/

22. Revista Politecnica - http://memoria.poli.usp.br/discover

23. Scientific Electronic Library Online (Scielo) - http://www.scielo.org/php/index.php

24. Sistema Integrado de Bibliotecas da Universidade de São Paulo (SIBiUSP) - http:// 
www.buscaintegrada.usp.br/primo_library/libweb/action/search.do

25. UNESCO - https://en.unesco.org/

26. http://www.vitruvius.com.br 
O presente trabalho foi realizado, parcialmente, com apoio da Coordenação de Aperfeiçoamento de Pessoal de Nível Superior - Brasil (CAPES) 
Anexo 


\section{Caracterização da área de estudo}

\section{História}

A região onde está localizado o município de Espírito Santo do Pinhal tem suas origens em meados do século XIX a partir da formação da Fazenda Pinhal, ainda território de Mogi-Guaçu. Diversas famílias migraram de outras partes do território paulista e de outros estados atraídas pelas oportunidades agrícolas da região. Um dos primeiros a se estabelecer na área foi a família de Romualdo de Souza Brito, que comprou as terras da fazenda Pinhal em 1845, além de outras propriedades da região. Pressionado por disputas pela posse das terras, resolveu doar, em 1949, 40 alqueires para a construção da capela do Divino Espirito Santo, como forma de solucionar os conflitos locais. Esse fato marcou o início da formação do povoado. Em 9 de abril de 1877, foi criado o município, que se desmembrou de Mogi-Guaçu e Mogi-Mirim, e alguns anos depois, em 1883, a sede municipal foi reconhecida como cidade. Em 1938 passou a ser denominada Pinhal, conforme decreto $n^{\circ}$ 9775, e voltou ao nome original em 1974.

A região onde se localiza o município faz parte da segunda zona cafeicultura do Estado e, desde então, esse produto agrícola ainda move a economia local e se destaca na produção de café de boa qualidade. Quando essa cultura se estabeleceu nos contrafortes da Mantiqueira, diversas localidades passaram por transformações administrativas, sociais, urbanísticas e econômicas. As vilas viraram cidades e as cidades se desenvolviam para comportar novos moradores que demandavam novas infraestruturas. Já na condição de cidade, foi inaugurada em 1889 a estação ferroviária de Pinhal, no setor oeste. O ramal da Companhia Mogiana de Estradas de Ferro partia da estação de Mogi-Guaçu e se estendia por 37 km, abrangendo as estações de Conselheiro Laurindo, Nova Lousã, Mota Paes e Pinhal.

O ciclo econômico do café promoveu o desenvolvimento do conjunto urbano em torno da igreja matriz e das praças, localizadas no ponto mais alto da colina, na cota 865 metros. A partir deste ponto, os arruamentos foram se consolidando, num esquema tabuleiro de xadrez, para os fundos de vale, principalmente em direção ao setor sudeste.

As edificações do núcleo original, referentes ao período compreendido entre 1880 e 1920, possuem alinhamento frontal do lote e são representativas de um estilo eclético, de influência neoclássica e técnica construtiva em alvenaria de tijolos (Condephaat). Essas características arquitetônicas somadas ao contexto histórico da época significou a proteção desses bens pelo Condephaat em 1992. Ao todo, são 11 imóveis tombados incluindo a Biblioteca e Museu localizados na Praça da Independência, residência de Arnaldo Florense, edifício da estação ferroviária, Casa Irmãos Sagiorato LTDA, depois retificado para Casa Afonso, Escola Estadual Dr. Almeida Vergueiro, Cine Teatro Avenida, Fachada da Antiga Farmácia e outro imóvel na Praça da Independência (Mapa 1). A área envoltória foi definida para a manutenção do traçado 
urbano, do gabarito das edificações e os visuais existentes, mas, curiosamente, não abrangeu três bens tombados, conforme limite estabelecido na Resolução SC-35 de 16/11/1992. Esses perímetros estão inseridos na Macrozona de Interesse Histórico, Artístico e Cultural do Plano Diretor Municipal e definida como áreas onde estão localizados os imóveis que possuem qualidades estéticas e históricas, significados culturais e afetivos, ou que constituam referências urbanas, ambientais e de memória que devem ser protegidos e preservados, a fim de evitar a perda ou desaparecimento das características que lhe conferem peculiaridade, observando as seguintes diretrizes:

- Preservação do centro histórico da fundação da cidade e

- Seu entorno, fundamental à valorização da identidade local;

- Incentivo à convivência do uso residencial e não

- Residencial, condicionada à promoção da qualidade ambiental;

- Estabelecimento de critério de isonomia na fixação do

- Potencial de aproveitamento dos imóveis

No mapa do Plano Diretor municipal essas áreas estão associadas à Área de Interesse Paisagistico. 


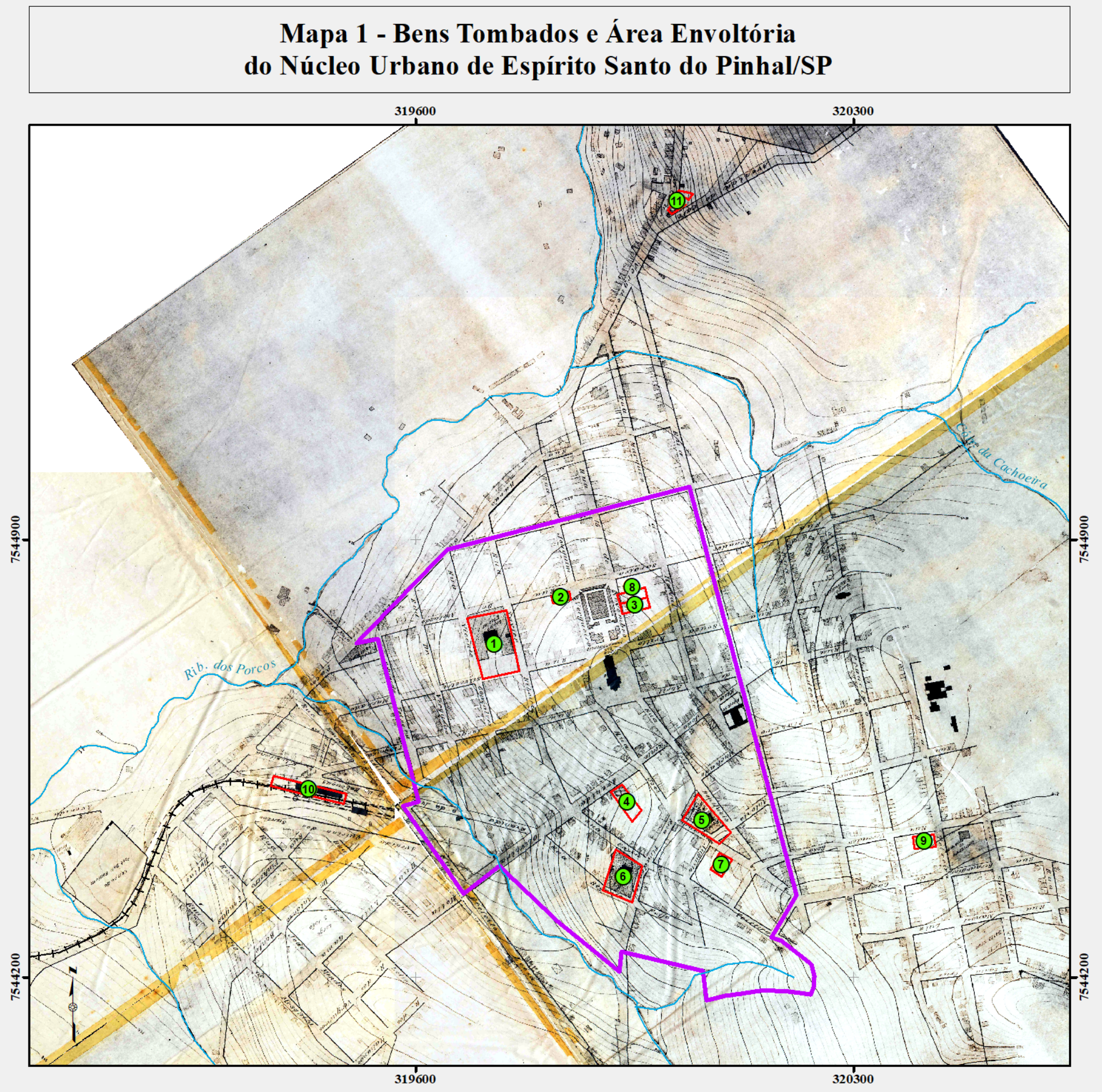

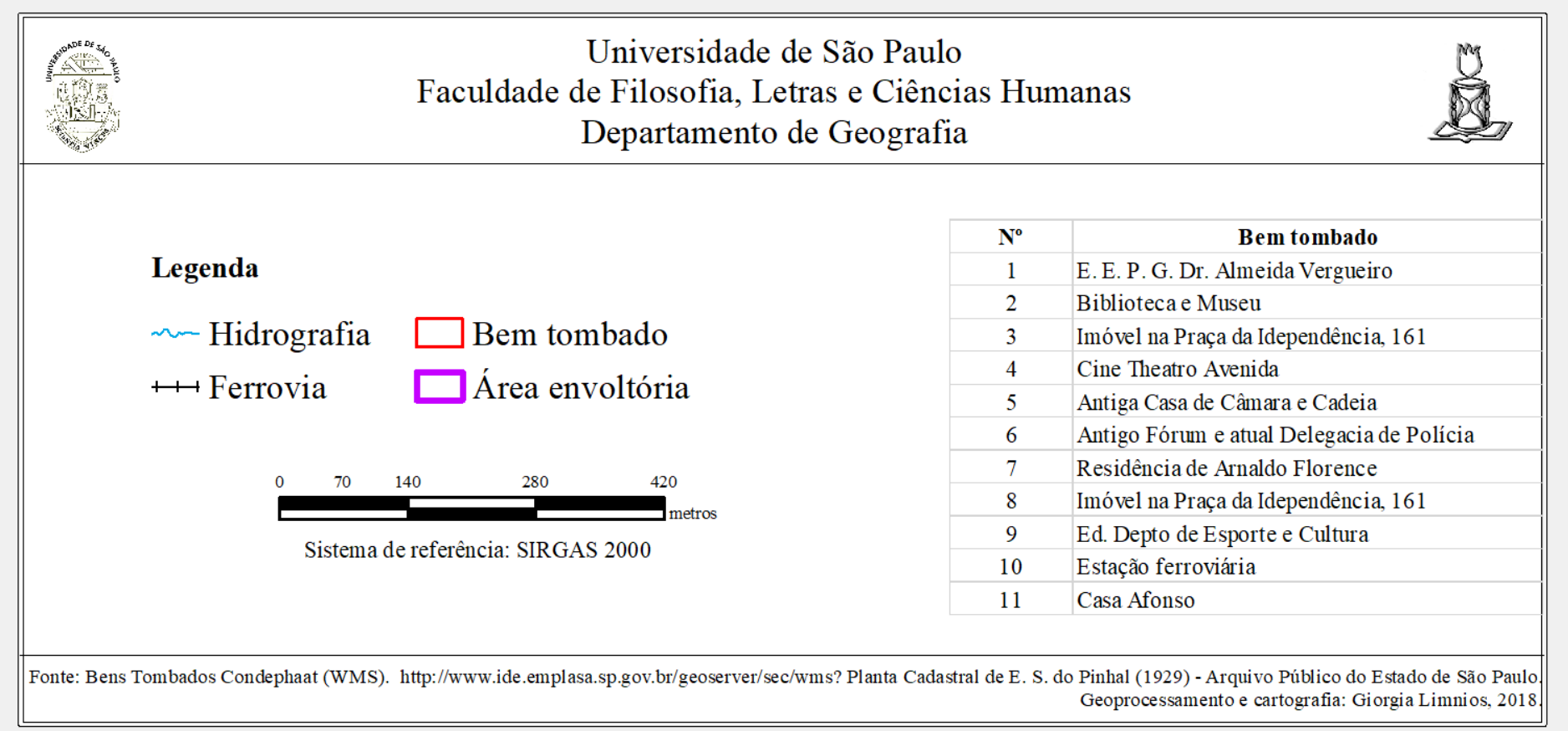




\section{Perfil municipal}

No território de 389,24 km² de Espírito Santo do Pinhal vive uma população estimada de 42.461 habitantes, nos quais $90,8 \%$ se estabeleceram na área urbana. A maioria das residências e comérciostemabastecimentodeágua(98,99\%), coleta delixo(99,88\%)queéenviadoaomunicípio de Paulínia; e coleta de esgoto $(98,1 \%$ ) com alto índice de tratabilidade, com valor atribuído de 9.97

(SEADE, 2015). Um dado apresentado pelo IBGE , indica que 57,6\% dos domicílios urbanos localizam-se em vias com arborização urbana, índice modesto para um aspecto diretamente relacionado à qualidade de vida da população.

Economicamente, a atividade do setor terciário corresponde ao maior percentual do Produto Interno Bruto (PIB) municipal, seguido do setor secundário e primário (gráfico 1).

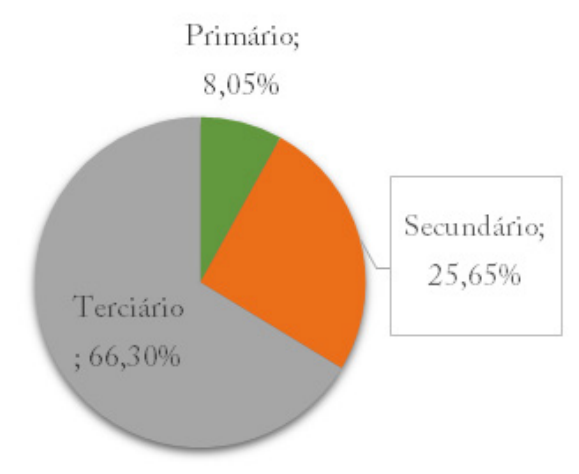

Gráfico 1. Percentual do Produto Interno Bruto (PIB) municipal. Fonte: Ministério do Desenvolvimento, Indústria e Comércio Exterior, Fundação Seade (2015)

Apesar do setor primário apresentar pequena participação no Produto Interno Bruto PIB, a produção cafeeira tem grande importância na economia local. Dos 16.244 ha de área destinada à produção agrícola no município, quase metade é utilizada para o cultivo do café ( 7.800 ha), principalmente a do tipo arábica, com quantitativo total de 13.800 toneladas no ano de 2016 (IBGE , 2018).

Entre o período de 2016 e 2017 alguns produtos da lavoura permanente (café, abacate, laranja) e da lavoura temporária (milho e cana de açúcar) tiveram queda na quantidade produzida. Enquanto isso, verificou-se um acréscimo, em torno de 13\%, na área plantada de eucalipto com o objetivo de produzir lenha, madeira em tora, produção de papel e sementes.

A área de estudo está localizada no setor sudeste do município e está totalmente inserida zona rural e nela observa-se que o uso da terra para a agricultura concentra o cultivo de dois produtos, café e eucalipto, com substituição do primeiro pelo segundo em algumas áreas desde 2010. 


\section{Meio físico}

A maior parte do território municipal, 77\%, está inserido na unidade morfoescultural do Planalto Atlântico, caracterizado por litologias diversas, quase sempre metamórficas associadas com intrusivas. Apresenta grande variação altimétrica, elevada densidade de drenagem, relevo com dissecação média e alta e topos convexos, correspondendo ao domínio de "mares de morros" definido por Aziz Ab' Saber (Ross \& Moroz, 1996). No município, o modelado é constituído por morros baixos, com altitudes que variam entre 650 e 1280 metros no sentido leste-oeste, embasamento litológico composto por gnaisses, com declividades que variam de 10 a $20 \%$, nas menores altitudes, e valores acima de 30\% nas maiores altitudes, que confere graus de fragilidade média e alta. A área urbana está consolidada sobre essa tipologia de relevo. $\mathrm{O}$ restante do território municipal, 23\%, está incluída na unidade Planalto Ocidental Paulista, que compreende metade do estado de São Paulo. Caracterizado por relevos levemente ondulados, com predomínio de colinas amplas e baixas com topos aplanados, vales pouco encaixados e baixa densidade de drenagem. As altitudes predominantes variam de 800 a 1000 metros, com declividades entre 10 e 20\%, os níveis altimétricos são menores, que reflete baixa fragilidade do ambiente. Em diversos cursos d' água observa-se a ocorrência de afloramentos basálticos que condicionou a preferência para a implementação das PCHs nessa unidade geomorfológica. Nas zonas oeste e norte do município, essa unidade possui elevações que variam entre 640 e 880 metros. (Mapa 2) 


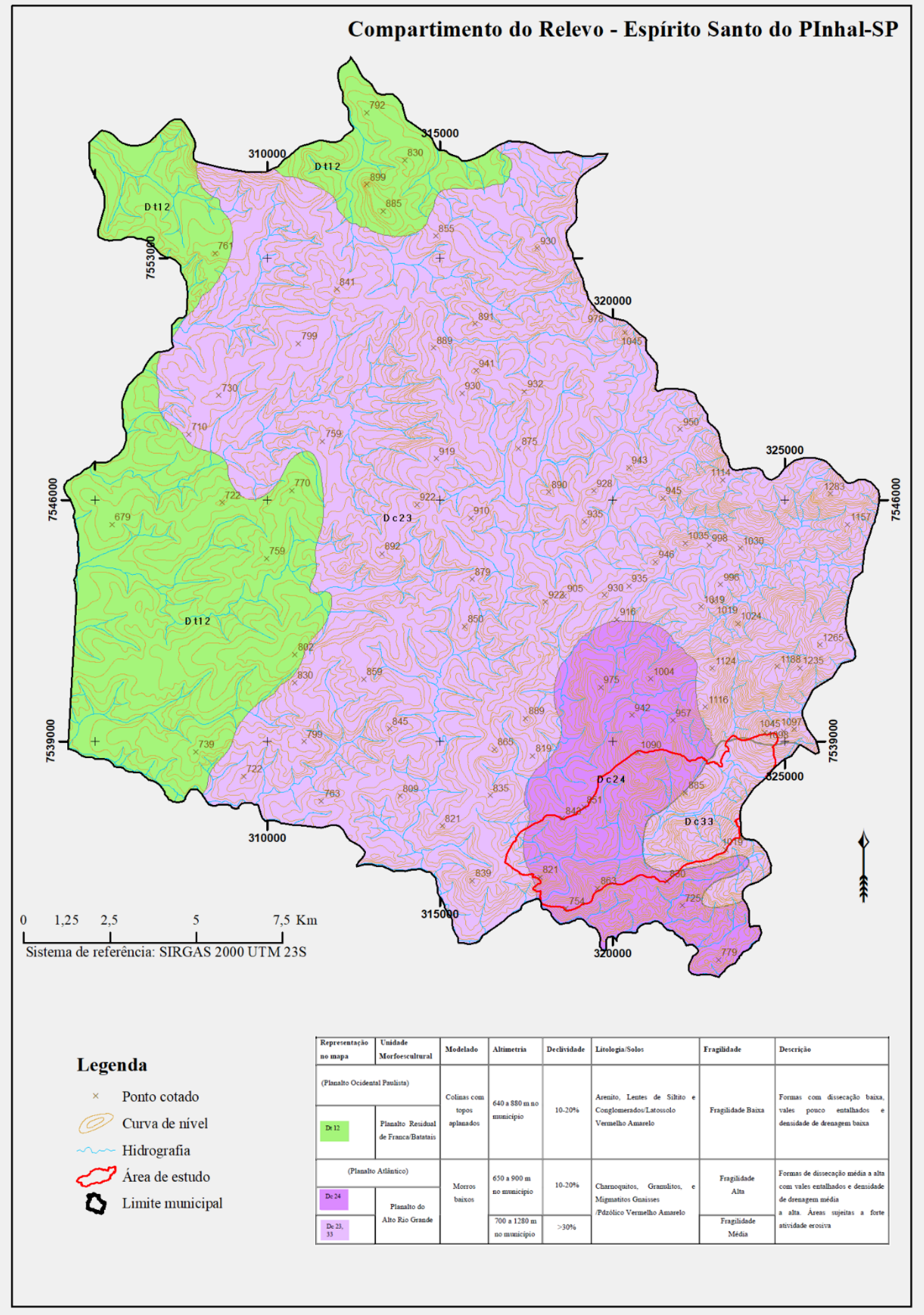

Mapa 2. Geomorfologia Fonte: Adaptado de Ross \& Moroz, 1996. Modificado Giorgia Limnios, 2018. 


\section{Clima}

A localização do município no limite entre o Planalto Atlântico e o Planalto Ocidental, na altitude de 800 metros, confere um clima com temperaturas amenas. Segundo a classificação internacional de Koeppen, organizado a partir de dados mensais de chuvas e temperaturas, o Estado de São Paulo possui 6 tipos climáticos tropicais e temperados. Os climas tropicais (A) são subdivididos em Af - tropical úmido sem estação seca e Aw - tropical úmido com inverno seco. Os climas temperados (C) são subdivididos em Cwa - quente com inverno seco, Cwb temperado com inverno seco, Cfa - quente sem estação seca e Cfb - temperado sem estação seca conforme Mapa 3. (Martinelli, 2010).

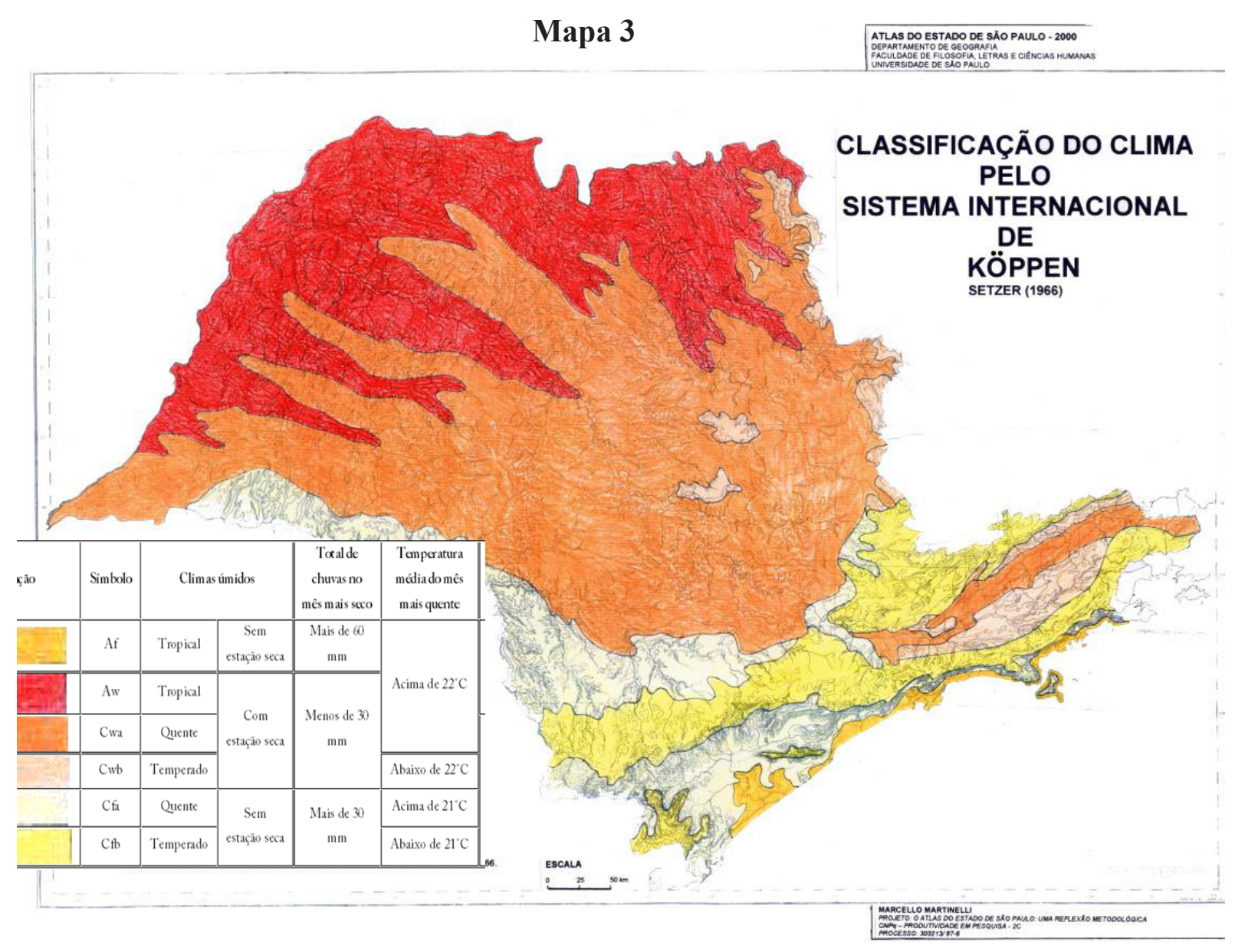

No município em questão existe dois tipos climáticos temperados: o Cwa, que abrange toda a parte central do Estado de São Paulo, caracterizado pelo clima tropical de altitude, com chuvas no verão e seca no inverno, com a temperatura média do mês mais quente superior a $22^{\circ} \mathrm{C}$. A influência da altitude em algumas áreas serranas proporcionam verões são mais amenos, classificados como $\mathrm{Cwb}$, onde a temperatura média do mês mais quente é inferior a $22^{\circ} \mathrm{C} \mathrm{e}$ 
“durante pelo menos quatro meses é superior a $10{ }^{\circ} \mathrm{C} "$. (CEPAGRI $)^{1}$. Os períodos secos e chuvosos apresentam totais mensais inferiores e superiores em relação ao tipo Cwa, com estações mais definidas. Os quadros seguintes apresentam dados de temperaturas - mínimas e máximas médias - e chuvas para os tipos climáticos Cwa e Cwb.

Em geral, o regime de chuvas nessa região é influenciado pela atuação da Zona de Convergência do Atlântico Sul (ZCAS), pela passagem de frentes frias e pelas condições de forte instabilidade termodinâmica, muitas vezes incrementada pela atuação do Jato de Baixos Níveis (JBN) que transporta umidade da Amazônia para o Sul e o Sudeste do Brasil.

Tabela 1. Síntese dos dados para os tipos climáticos Cwa e Cwb.

\begin{tabular}{|c|c|c|c|c|c|c|c|c|c|}
\hline \multirow{2}{*}{ MÊS } & \multicolumn{3}{|c|}{$\begin{array}{l}\text { TEMPERATURA DO } \\
\text { AR }\left({ }^{\circ} \mathrm{C}\right) \text { - Cwa }\end{array}$} & \multirow[t]{2}{*}{$\begin{array}{c}\text { CHUVA } \\
(\mathrm{mm}) \\
\end{array}$} & \multirow{3}{*}{ MÊS } & \multicolumn{3}{|c|}{$\begin{array}{l}\text { TEMPERATURA DO } \\
\text { AR }\left({ }^{\circ} \mathrm{C}\right) \text { - Cwb }\end{array}$} & \multirow[t]{3}{*}{$\begin{array}{l}\text { CHUVA } \\
(\mathrm{mm}) \\
\end{array}$} \\
\hline & $\begin{array}{l}\text { Mín. } \\
\text { média }\end{array}$ & $\begin{array}{l}\text { Máx. } \\
\text { média }\end{array}$ & Média & & & Mín. & Máx. & Média & \\
\hline JAN & 17.1 & 27.9 & 22.5 & 261.2 & & media & média & & \\
\hline FEV & 17.3 & 27.8 & 22.6 & 223.6 & JAIr & 10.5 & 27.0 & 21.8 & 286.9 \\
\hline MAR & 165 & & & & FEV & 16.7 & 26.9 & 21.8 & 227.5 \\
\hline MAN & 10.5 & 21.0 & 22.1 & 104.5 & MAR & 16.1 & 27.0 & 21.5 & 181.1 \\
\hline ABR & 13.9 & 26.1 & 20.0 & 84.2 & ABR & 13.7 & 26.2 & 20.0 & 84.0 \\
\hline MAI & 11.3 & 24.4 & 17.8 & 59.1 & MAI & 11.1 & 24.8 & 18.0 & 49.1 \\
\hline JUN & 9.8 & 23.3 & 16.6 & 45.6 & JUN & 9.9 & 24.0 & 16.9 & 23.7 \\
\hline JUL & 9.3 & 23.5 & 16.4 & 27.0 & JUL & 9.4 & 24.3 & 16.9 & 18.6 \\
\hline AGO & 10.6 & 25.6 & 18.1 & 32.3 & AGO & 10.9 & 26.8 & 18.8 & 18.0 \\
\hline SET & 12.6 & 26.9 & 19.8 & 62.5 & SET & 13.0 & 28.5 & 20.8 & 63.5 \\
\hline OUT & 14.5 & 27.1 & 20.8 & 133.4 & OUT & 14.9 & 28.0 & 21.5 & 144.5 \\
\hline NOV & 15.3 & 27.3 & 21.3 & 171.1 & NOV & 15.4 & 27.3 & 21.4 & 190.9 \\
\hline DEZ & 16.4 & 27.2 & 21.8 & 256.3 & DEZ & 16.2 & 26.8 & 21.5 & 257.2 \\
\hline Ano & 13.7 & 26.2 & 20.0 & 1540.6 & Ano & 13.7 & 26.5 & 20.1 & 1545.0 \\
\hline Min & 9.3 & 23.3 & 16.4 & 27.0 & Min & 9.4 & 24.0 & 16.9 & 18.0 \\
\hline Max & 17.3 & 27.9 & 22.6 & 261.2 & Max & 16.7 & 28.5 & 21.8 & 286.9 \\
\hline
\end{tabular}

Fonte: Cepagri. Org. Giorgia Limnios, 2018.

Os dados apresentados pelo Centro Integrado de Informações Agrometeorológicas (CIIAGRO) para a estação meteorológica localizada no município de Espirito Santo do Pinhal, no período de 01/07/2002 a 14/05/2018, indicam que as temperaturas máximas atingem $38^{\circ} \mathrm{C}$ no verão com um máximo ocorrido em janeiro de 2017 em que a temperatura alcançou $42,7^{\circ} \mathrm{C}$. As mínimas giram em torno de $15^{\circ} \mathrm{C}$, porém verificou-se uma queda acentuada para $0,8^{\circ} \mathrm{C} \mathrm{em}$ 
junho de 2016. Quanto às chuvas, nota-se que até 2008 os verões foram mais chuvosos que os últimos 10 anos. Entre 11/01/2007 a 04/02/2007 choveu $1.718 \mathrm{~mm}$, valor bem superior ao total anual dos tipos climáticos Cwa e Cwb.

Em 2014 foi observado grande redução de chuvas no Estado de São Paulo, causado pela persistência de uma zona de alta pressão atmosférica (que indica bom tempo), na região sudeste, deixando o ar mais seco e estável, o qual impedia a passagem de frentes úmidas. Foi o período mais seco em 45 anos, ocasionando falta de água em diversos municípios pela seca dos mananciais. Mas o fator climático não foi o único responsável pela crise hídrica deste período. As políticas ambientais desastrosas que favorecem o desmatamento e o intenso uso dos recursos naturais, a exemplo do Novo Código Florestal de 2012 que praticamente elimina a proteção das áreas de preservação permanente e das reservas legais, fundamentais na produção e qualidade hídrica, na proteção de encostas com redução dos riscos à vida, à manutenção da biodiversidade, à provisão dos serviços ecossistêmicos e outros.

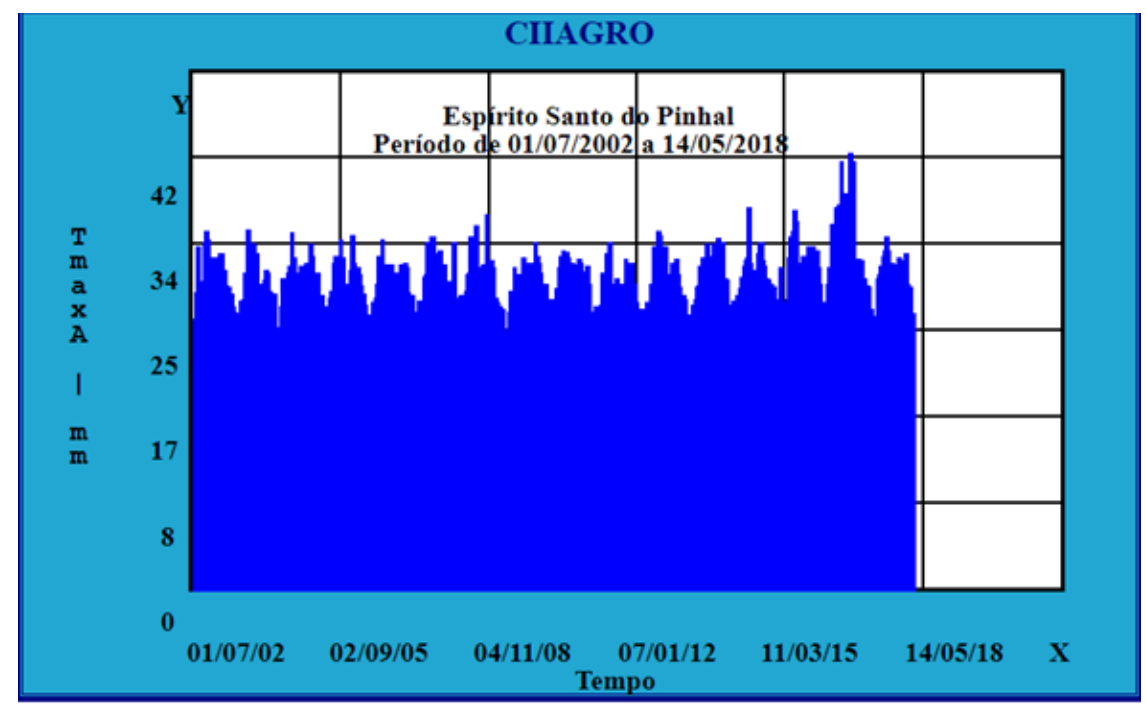

Gráfico 1. Temperatura máxima no município de Espirito Santo do Pinhal entre 01/07/2002 a 14/05/2018. Fonte: CIIAGRO, 2018. 


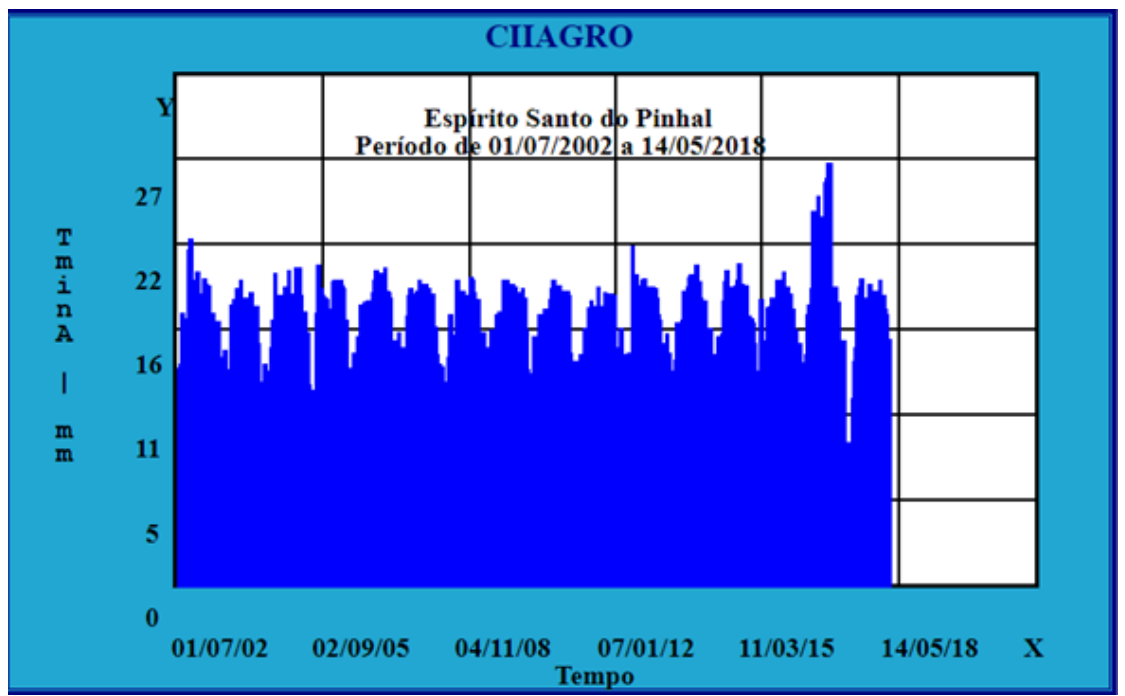

Gráfico 1. Temperatura mínima no município de Espirito Santo do Pinhal entre 01/07/2002 a 14/05/2018. Fonte: CIIAGRO, 2018.

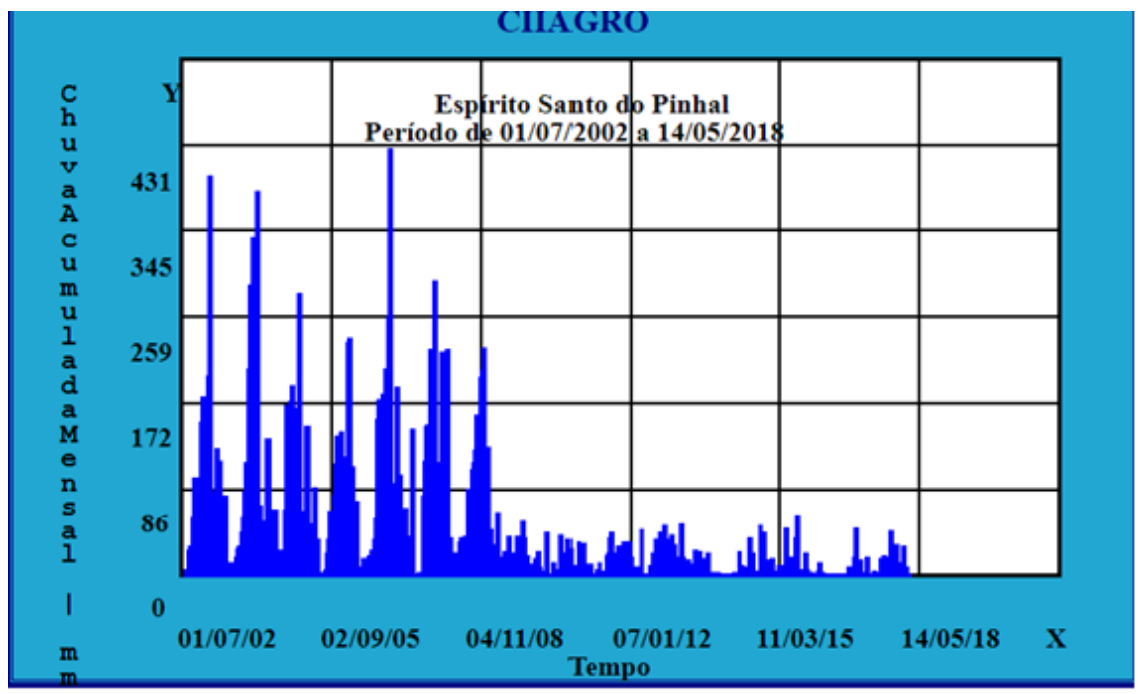

Gráfico 1. Chuva acumulada no município de Espirito Santo do Pinhal entre 01/07/2002 a 14/05/2018. Fonte: CIIAGRO, 2018.

\section{Cobertura vegetal}

A cobertura vegetal natural do município é caracterizada pela ocorrência da Floresta Estacional Semidecidual Submontana (FES), abrangida pelo domínio das Matas Atlânticas. Essa formação vegetacional ocorre no planalto ocidental paulista, na faixa altitudinal entre 300 e 900 metros. O fato de ocorrer nas áreas mais interiorizadas sob climas estacionais, com secas bem marcadas e verões chuvosos, lhe confere fisionomia com folhagens mais secas, podendo perder parcial ou totalmente suas folhagens. Na zona tropical, associa-se à região marcada por 
acentuada seca e por intensas chuvas de verão; na zona subtropical, está relacionada a clima sem período seco, porém com inverno bastante frio (temperaturas médias mensais inferiores a $15^{\circ} \mathrm{C}$ ), que determina repouso fisiológico e queda parcial da folhagem (IBGE, 2012)

Assim como as florestas mais úmidas do planalto atlântico, foram estabelecidas faixas altitudinais conforme a latitude em que está situada. No estado de São Paulo, as florestas semidecíduas compreendem duas formações que ocorrem em contato com Cerrado: a Submontana que se situa na faixa 50 a $500 \mathrm{~m}$, no oeste paulista, e a Montana que ocorre entre as altitudes de 500 a 1.500 m, principalmente nos contrafortes ocidentais da Serra da Mantiqueira (Figura 1).

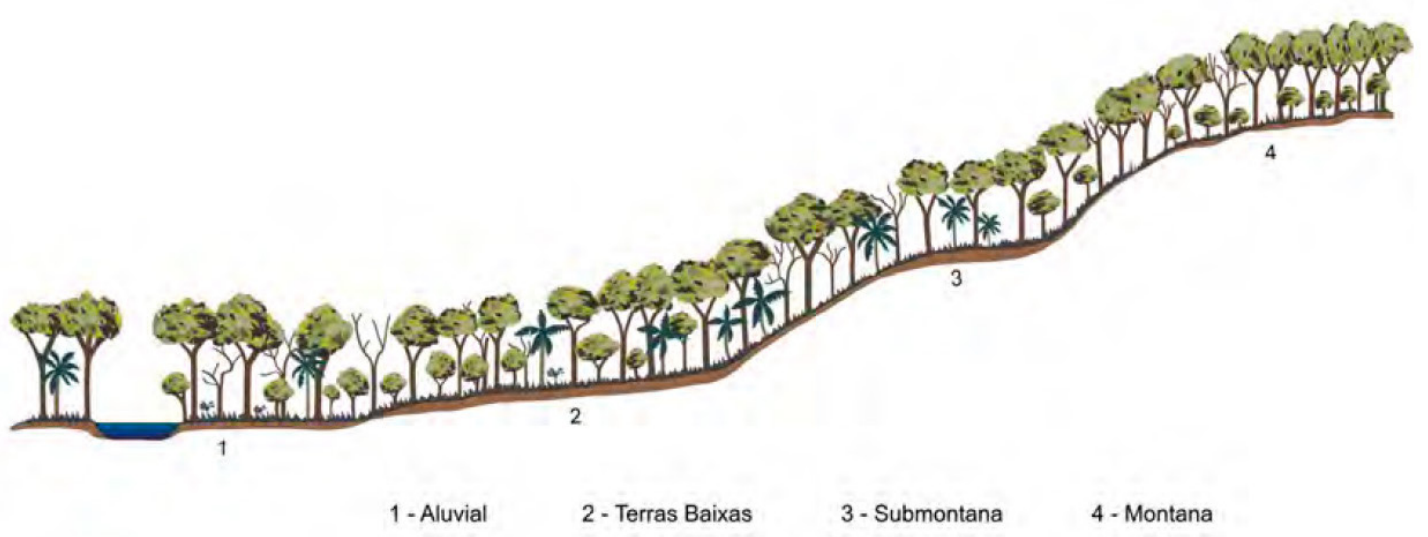

Figura 1. Perfil esquemático da Floresta Estacional Semidecidual. Autor: Veloso, Rangel Filho e Lima (1991), IBGE, 2012.

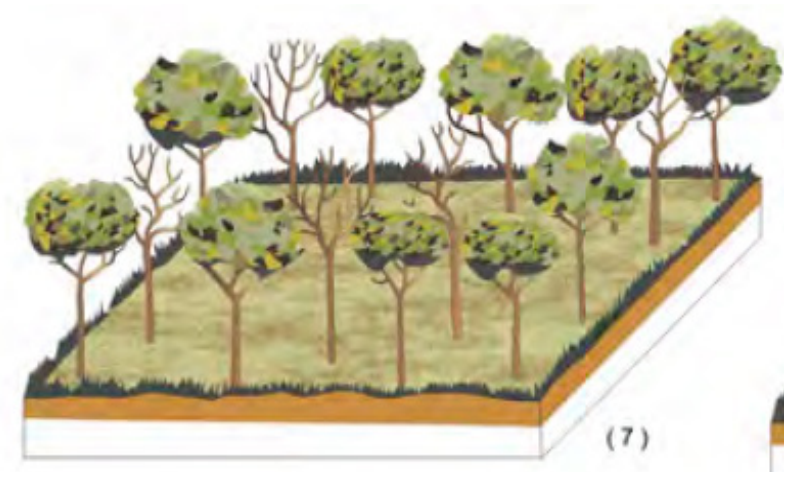

Figura 2. Bloco diagrama da Floresta Estacional Semidecidual. Autor: Veloso, Rangel Filho e Lima (1991), IBGE, 2012.

O topônimo Pinhal, presente no nome, refere-se à presença da espécie Araucaria angustifolia na região, bem mais abundante em tempos passados. Essa linda árvore nativa do Brasil estampa o brasão municipal, poucos exemplares são observados no território em virtude dos desmatamentos ocorridos para a produção agrícola, para o uso da madeira com finalidade co- 
mercial e pela ausência de políticas ambientais para a proteção da espécie. Ocorre nas altitudes acima de 900 metros, na região sudeste, e acima de 400 metros na região sul do país, em climas mais frios e com alta umidade. Naturalmente, essa planta ocorre na forma de agrupamentos, bastante homogêneos, dominando o dossel superior, pois chega a atingir 50 metros de altura. Esse conjunto arbóreo com dominância de pinheiros, em associação com o pinheiro bravo (Podocarpos lambertii) e outras espécies, também é designada como Floresta Ombrófila Mista.

São identificadas quatro formações da Floresta Ombrófila Mista (Figura ): - Aluvial: em terraços antigos associados à rede hidrográfica; - Submontana: constituindo disjunções em altitudes inferiores a 400 m; - Montana: situada aproximadamente entre 400 e 1000 m de altitude; e - Alto-Montana: compreendendo as altitudes superiores a 1000 m (Figura 1).

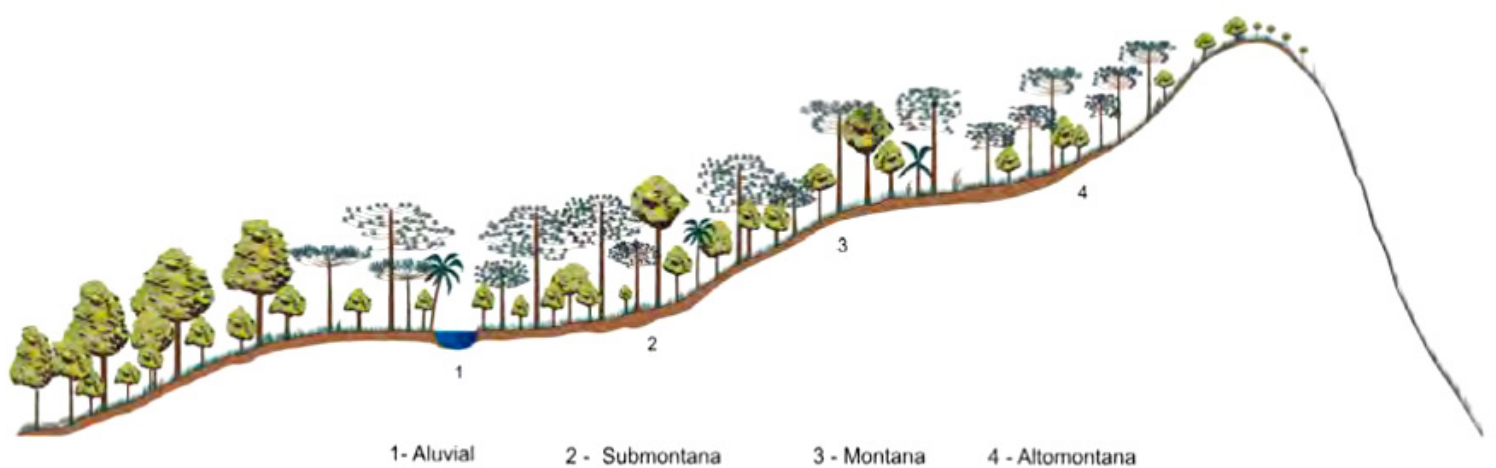

Figura 3. Perfil esquemático da Floresta Ombrófila Mista (Mata de Araucária). Fonte: Veloso, Rangel Filho e Lima (1991). In: IBGE, 2012.

Infelizmente, a araucária está indicada na lista vermelha das espécies da flora ameaçadas de extinção ${ }^{2}$, categorizada como EM “Em perigo" com declínio medido ao longo de 10 anos ou 3 gerações, com taxa de redução $\geq 50 \%$.

É utilizada na arborização urbana, como paisagismo, principalmente nas áreas centrais do município. Os frutos são muito apreciados pela fauna e pela população.

2 As espécies são classificadas em 9 grupos, definidos através de critérios que incluem a taxa de declínio da população -- entendida como o número de indivíduos por espécie --, o tamanho e distribuição da população, a área de distribuição geográfica e grau de fragmentação. Categoria EN “Em perigo" São espécies que enfrentam um risco muito elevado de extinção na natureza.. PORTARIA No 443, DE 17 DE DEZEMBRO DE 2014. Fonte: http:// www.mma.gov.br/biodiversidade/especies-ameacadas-de-extincao/flora-ameacada. 


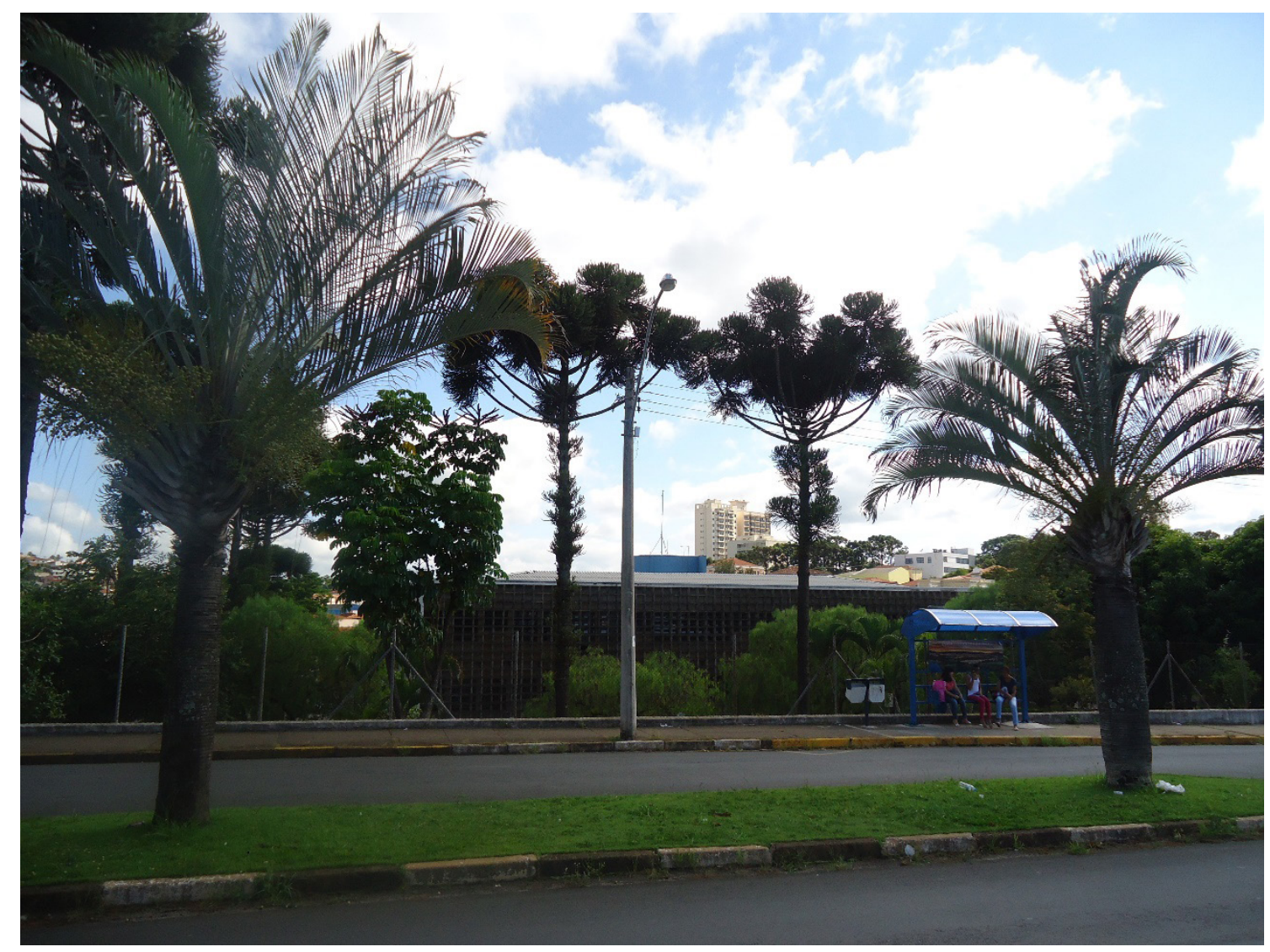

Figura 4 - Arborização urbana com Araucárias. Foto: Giorgia Limnios, Fev/2017.

\section{Panorama Ambiental}

O território de Espírito Santo do Pinhal está totalmente inserido na Unidade de Gerenciamento dos Recursos Hídricos do Rio Mogi-Guaçu (UGRHI - 9), que abrange outros 37 municípios paulistas e 17 municípios do estado de Minas Gerais, totalizando aproximadamente 17.922,74 km² de área. No Estado de São Paulo, dos $15.152 \mathrm{~km} 2$ de área, apenas $1.598 \mathrm{~km} 2$ $(10,5 \%)$ são revestidas de vegetação natural remanescente da Floresta Estacional Semidecidual, do Cerrado e Florestas Arbórea/Arbustiva em Regiões de Várzea (Instituto Florestal, 2010). No município, a área de recobrimento vegetal corresponde a 19,90\% do território, totalizando 1081 fragmentos $^{3}$ com tamanhos que variam de 0,25 ha a 437 ha. No mapa 1 e tabela 1 verifica-se a existência de muitos fragmentos pequenos, dispersos pelo município e os poucos fragmentos grandes que se localizam, principalmente, a oeste e sul do território.

$3 \quad$ Mapeamento do Inventário Florestal 2010. 
Tabela 1 - Total de fragmentos e respectivas áreas

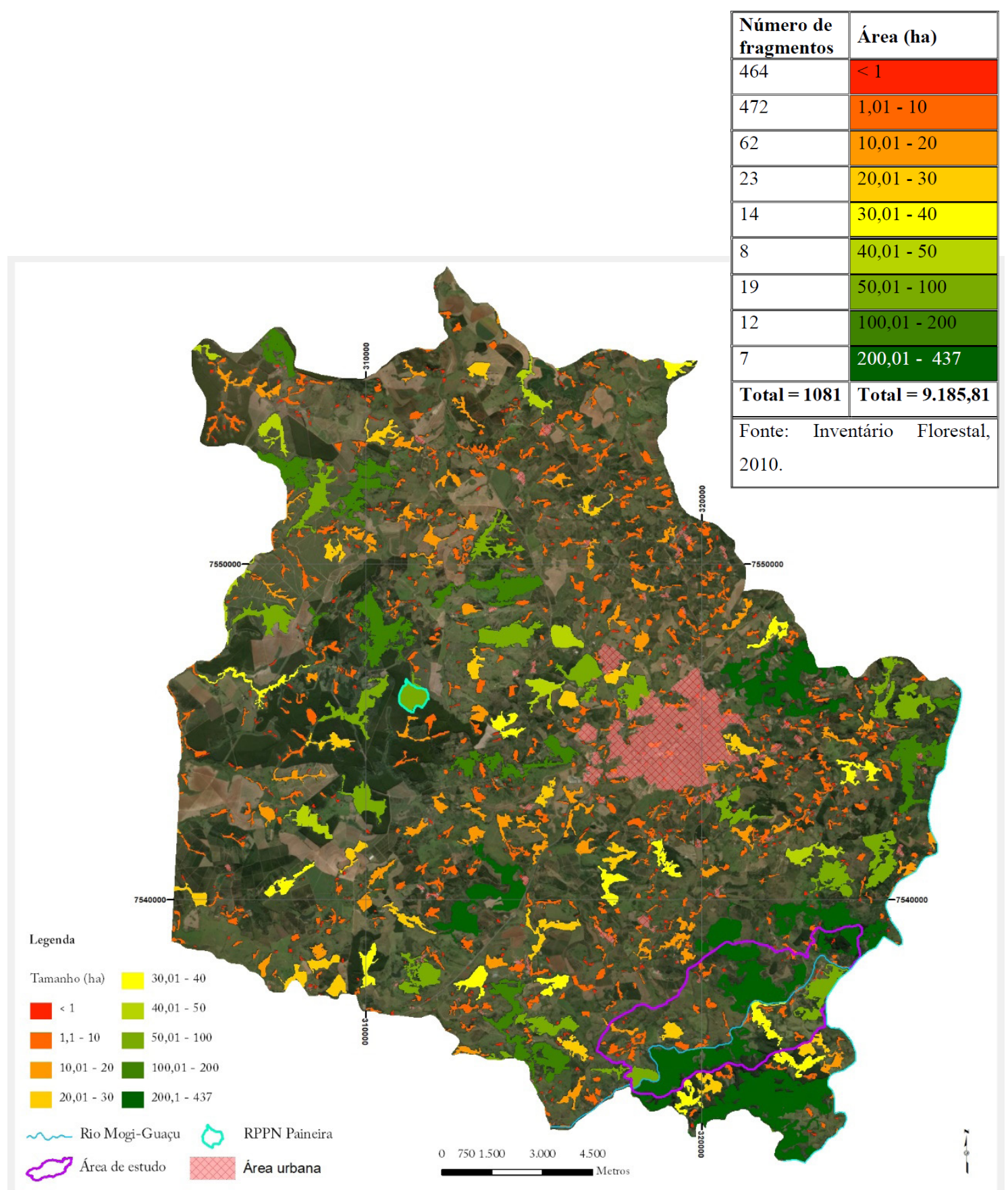

Mapa 4. Fragmentos florestais no município de Espírito Santo do Pinhal (SP). Fonte: Inventário Florestal, 2010 (WMS) e Emplasa. Cartografia e Geoprocessamento: Giorgia Limnios, 2018. 
Como toda e qualquer forma de vegetação nativa desempenha funções essenciais na sustentabilidade da vida é imprescindível sua proteção. O município possui, somente, uma unidade de conservação estadual de uso sustentável, a RPPN Paineira, que protege 49,80 hectares de vegetação ilhada em meio à cultura de eucalipto. No âmbito municipal ainda não houve iniciativa da prefeitura em criar espaços que conjuguem a proteção da vegetação, das águas e que sejam destinadas ao lazer da população. Os parques podem ser representativos quanto a esses objetivos e deveriam estar integrados no território como um compromisso social e ambiental pela municipalidade.

O Plano Diretor do Municipal estabelece em seu ordenamento áreas definidas como Macrozona de Proteção Ambiental que se destinam a conservar ou reconstituir a qualidade da vegetação de interesse ambiental, sendo permitidos usos que garantam tal qualidade, observando as seguintes diretrizes:

- Preservação, conservação e recuperação da vegetação de

- Interesse ambiental, através de manejo sustentável;

- Definição e delimitação de territórios passíveis de utilização, bem como aqueles especialmente protegidos com restrição à ocupação, através da proposição de zoneamento ambiental, estabelecendo normas e padrões específicos relativos ao uso e manejo dos recursos naturais;

- Desenvolvimento de atividades não geradoras de impacto;

- Respeito às condicionantes físicas do relevo e do solo;

- Garantia de áreas mínimas de permeabilidade 